
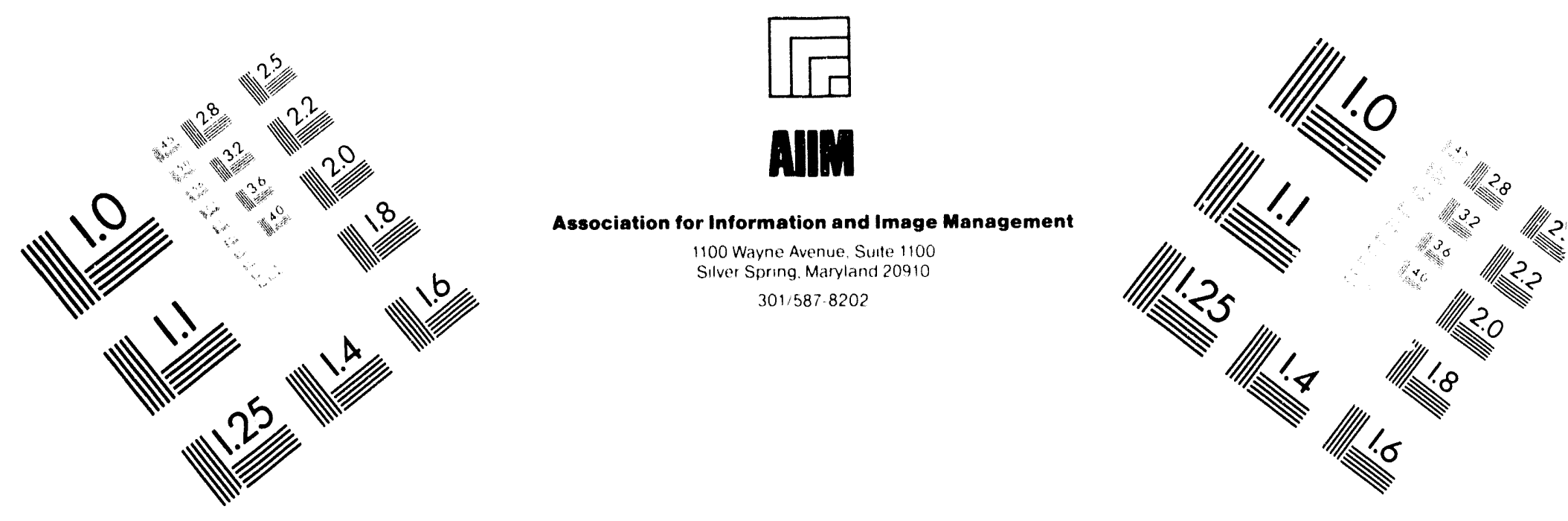

\title{
Centimeter
}

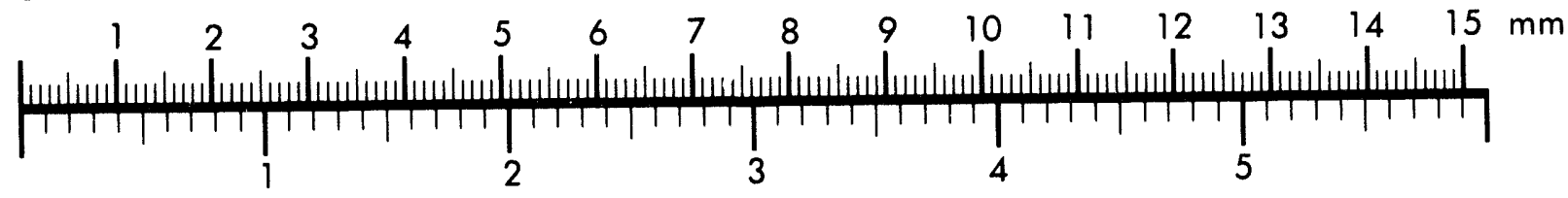
Inches
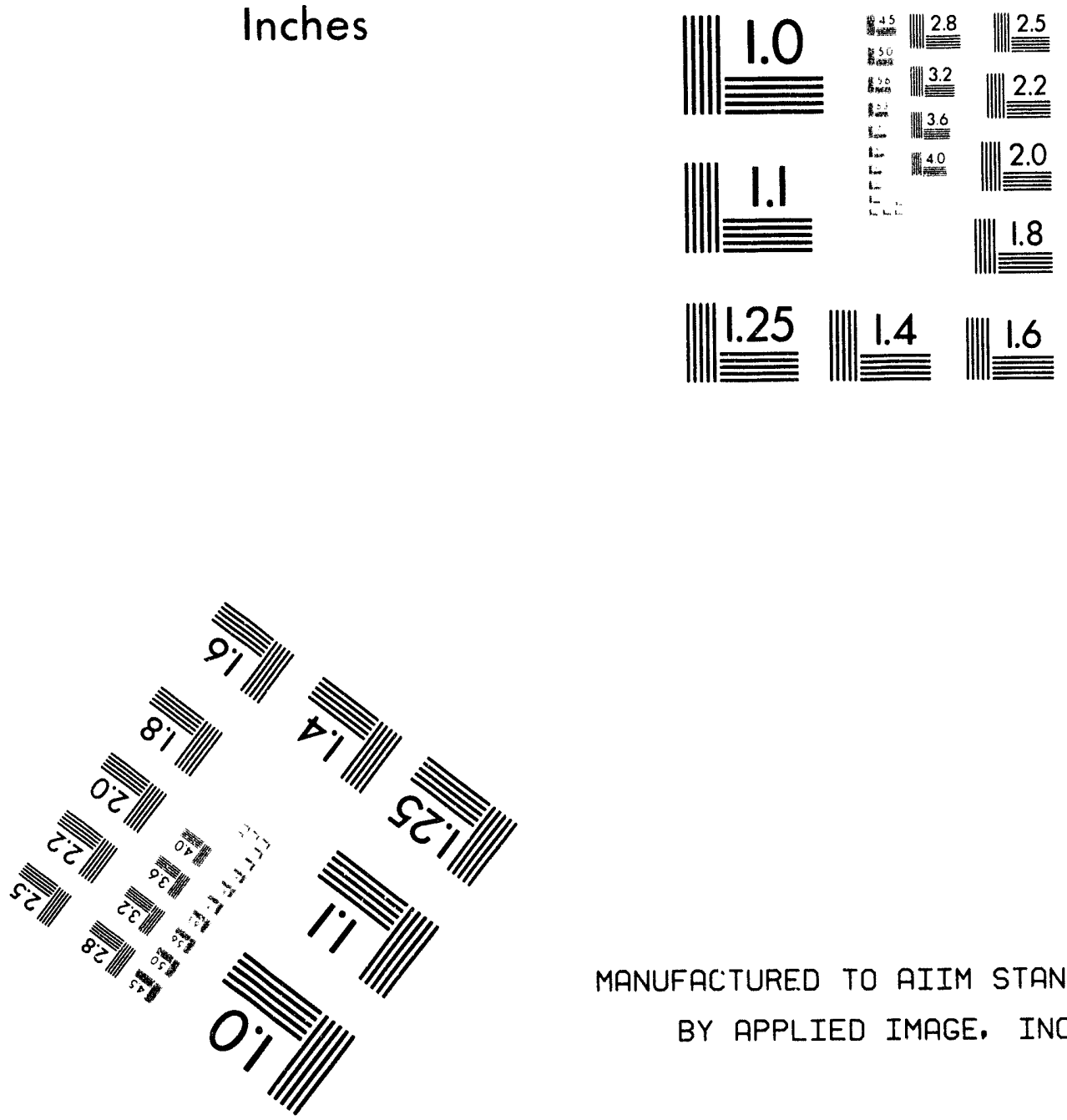

MANUFACTURED TO AIIM STANDARDS BY APPLIED IMAGE. INC.

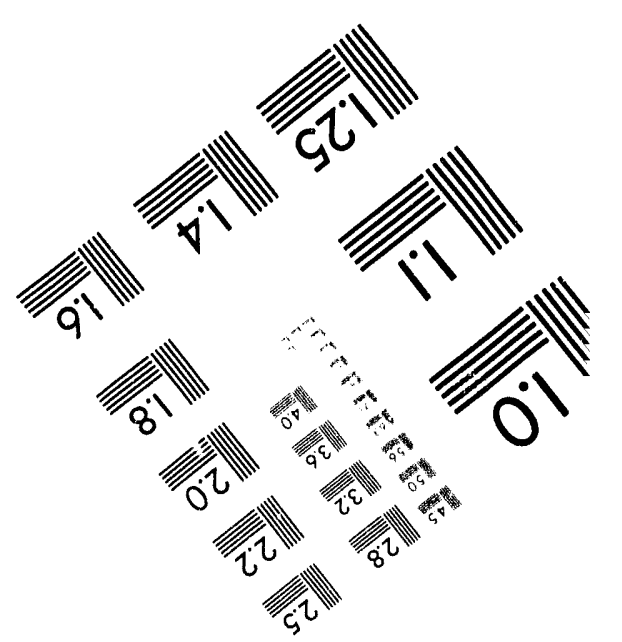



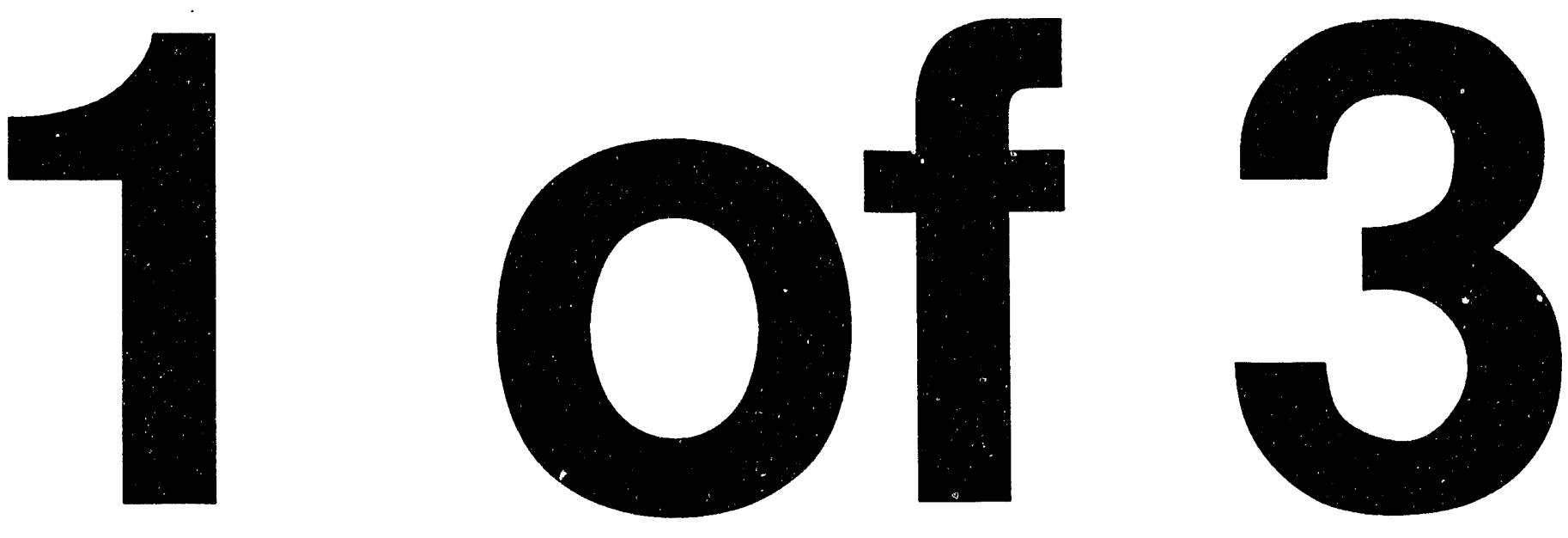
WHC-EP-0784

\section{Tank Exhaust Comparison with 40 CFR 61.93, Subpart H, and Other Referenced Guidelines for Tank Farms National Emission Standards for Hazardous Air Pollutant (NESHAP) Designated Stacks \\ D. D. Bachand \\ G. M. Crummel}

Date Published

July 1994

Prepared for the U.S. Department of Energy Office of Environmental Restoration and Waste Management

\footnotetext{
(Q) Westinghouse P.O. Box 1970

Hanford Company Richland, Washington 99352

Hanford Operations and Engineering Contractor for the

U.S. Department of Energy under Contract DE-AC06-87RL10930
} 


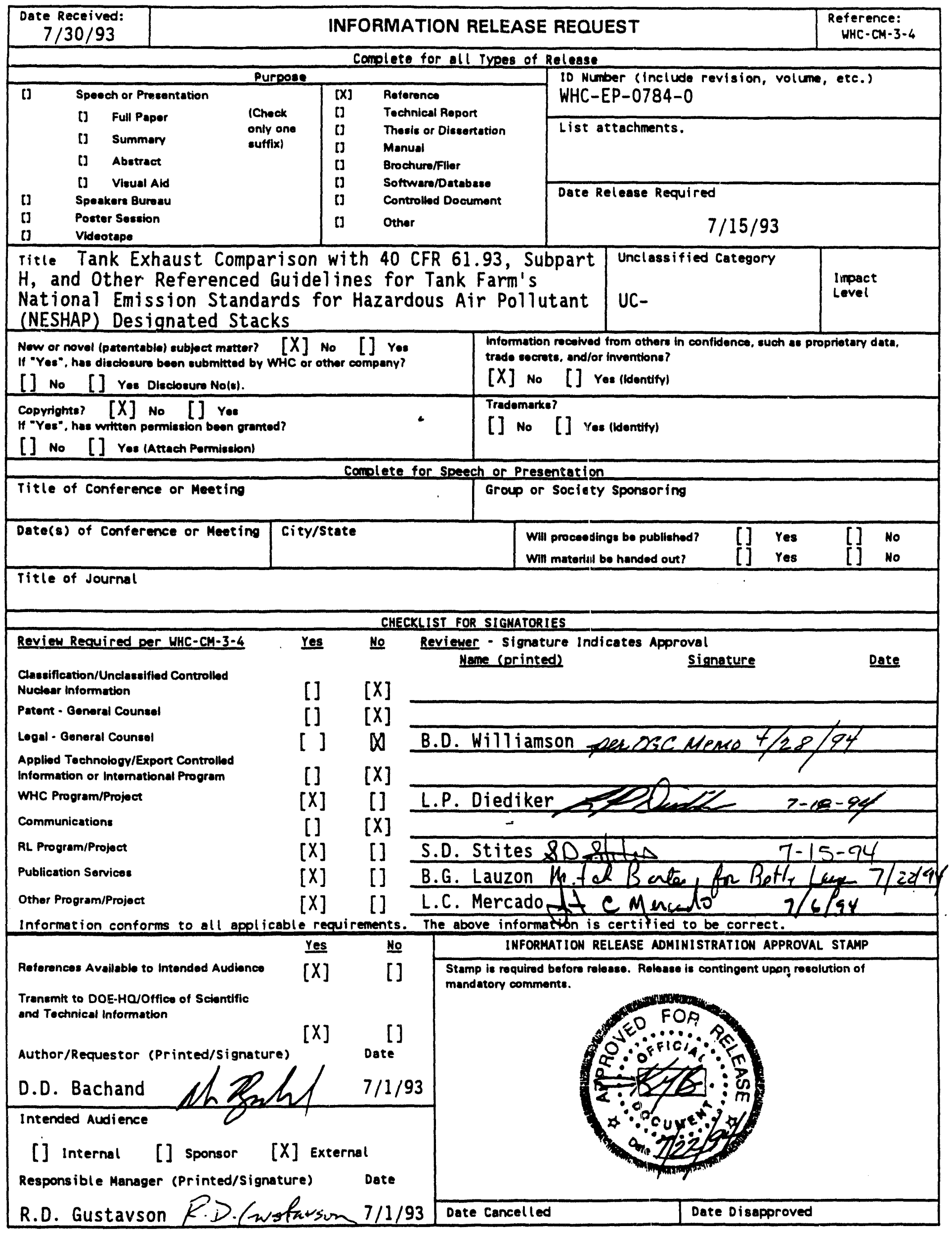




\section{CONTENTS}

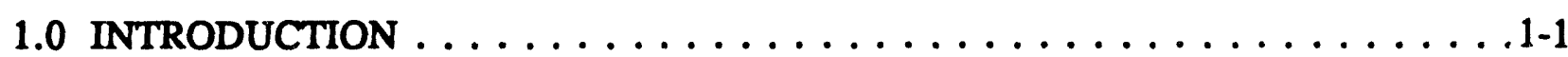

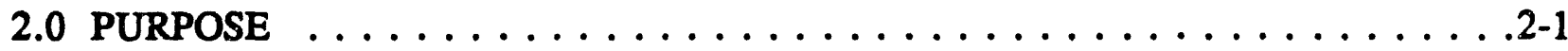

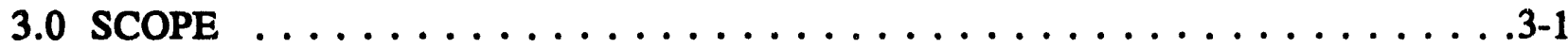

4.0 STRUCTURE OF POINT-BY-POINTS $\ldots \ldots \ldots \ldots \ldots \ldots \ldots \ldots \ldots$. . . . . .

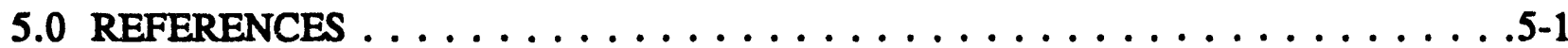
APPENDIXES

A 40 CFR 61.93 , SUBPART H COMPARISON FOR $296-A-17 \ldots \ldots \ldots \ldots \ldots$ A-1

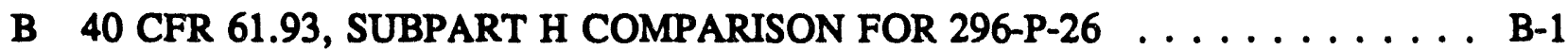

C 40 CFR 61.93, SUBPART H COMPARISON FOR $296-A-25 \ldots \ldots \ldots \ldots$ C-1

D 40 CFR 61.93, SUBPART H COMPARISON FOR 296-A-27 . . . . . . . D D-1

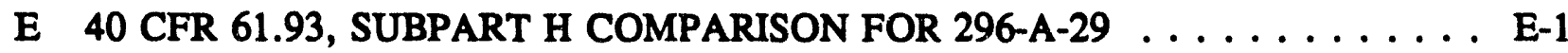

F 40 CFR 61.93, SUBPART H COMPARISON FOR 296-B-28 $\ldots \ldots \ldots \ldots \ldots$ F-1

G 40 CFR 61.93, SUBPART H COMPARISON FOR $296-C-5 \ldots \ldots \ldots \ldots$. . . .

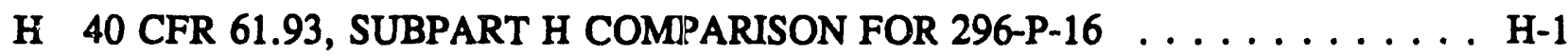

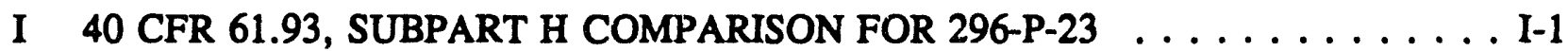

J 40 CFR 61.93, SUBPART H COMPARISON FOR 296-P-28 $\ldots \ldots \ldots \ldots \ldots$ J-1

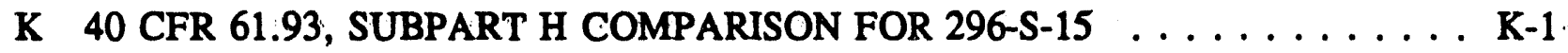

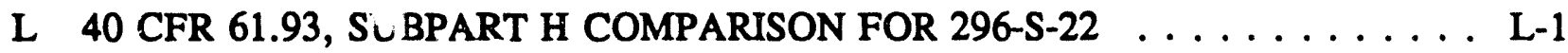

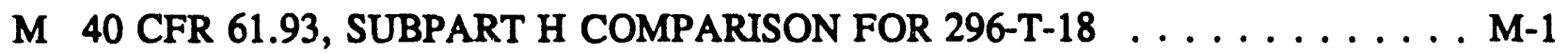

N SECTIONS COMMON TO EVERY POINT-BY-POINT $\ldots \ldots \ldots \ldots \ldots$ N-1 


\section{LIST OF FIGURES}

A-1 Stack Flow Distribution $296-A-17 \ldots \ldots \ldots \ldots \ldots \ldots \ldots \ldots \ldots$. . . . . . . . . .

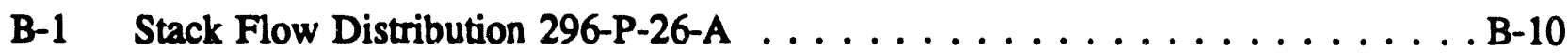

B-2 Stack Flow Distribution $296-\mathrm{P}-26-\mathrm{B} \ldots \ldots \ldots \ldots \ldots \ldots \ldots \ldots \ldots$ B-11

D-1 Stack Flow Distribution $296-A-27-A \ldots \ldots \ldots \ldots \ldots \ldots \ldots \ldots$ D-9

D-2 Stack Flow Distribution $296-A-27-B \ldots \ldots \ldots \ldots \ldots \ldots \ldots \ldots \ldots$ D-10

E-1 Stack Flow Distribution $296-A-29-A \ldots \ldots \ldots \ldots \ldots \ldots \ldots \ldots$. . . . . . E-10

E-2 Stack Flow Distribution $296-A-29-B \ldots \ldots \ldots \ldots \ldots \ldots \ldots \ldots \ldots \ldots$ E-11

F-1 Stack Flow Distribution $296-B-28-A \ldots \ldots \ldots \ldots \ldots \ldots \ldots \ldots \ldots$ F-11

G-1 Stack Flow Distribution $296-$ C-5-A $\ldots \ldots \ldots \ldots \ldots \ldots \ldots \ldots \ldots$. . . . . . . . . .

H-3 Stack Flow Distribution $296-\mathrm{P}-16-\mathrm{A} \ldots \ldots \ldots \ldots \ldots \ldots \ldots$. . . . . . . . . . .

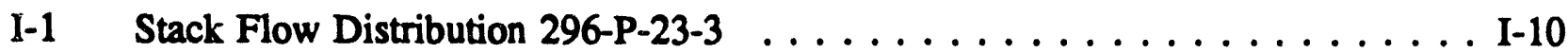

I-2 Stack Flow Distribution $296-\mathrm{P}-23-4 \ldots \ldots \ldots \ldots \ldots \ldots \ldots \ldots \ldots$ I-11

J-1 Stack Flow Distribution $296-\mathrm{P}-28-\mathrm{A} \ldots \ldots \ldots \ldots \ldots \ldots \ldots \ldots \ldots$

L-1 Stack Flow Distribution $296-$ S-22-A $\ldots \ldots \ldots \ldots \ldots \ldots \ldots \ldots \ldots$. . . . . . . .

M-1 Stack Flow Distribution 296-T-18-A $\ldots \ldots \ldots \ldots \ldots \ldots \ldots \ldots \ldots$ M-11 


\section{LIST OF TABLES}

C14 Stack Number 296-A-29 Sampling System Particle Penetration Percentage . . . E E-13

Stack Number 296-B-28 Sampling System Particle

Penetration Percentage . . . . . . . . . . . . . . . . . F-13

Stack Number 296-C-5 Sampling System Particle Penetration

Percentage . . . . . . . . . . . . . . . . . . . .G-12

C20 Stack Number 296-P-16 Sampling System Particle

Penetration Percentage . . . . . . . . . . . . . . . . H-12

Stack Number 296-P-23 Sampling System Particle Penetration

Percentage . . . . . . . . . . . . . . . . . . . I-13

C24 Stack Number 296-P-28 Sampling System Particle Penetration Percentage . . . . J-12

Stack Number 296-S-15 Sampling System Particle Penetration

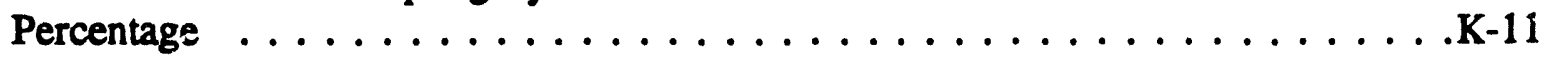

Stack Number 296-S-22 Sampling System Particle Penetration

Percentage $\ldots \ldots \ldots \ldots \ldots \ldots \ldots \ldots \ldots \ldots \ldots \ldots \ldots$. . . . . . . . . . . 


\section{LIST OF TERMS}

CAM

DOE

EDE

EPA

FFCA

L

NESHAP

WHC
Continuous Air Monitor

U.S. Department of Energy

Effective Dose Equivalent

U.S. Environmental Protection Agency

Federal Facilities Compliance Agreement

Liter

National Emission Standards For Hazardous Air Pollutant

Westinghouse Hanford Company 


\section{TANK EXHAUST COMPARISON WITH 40 CFR 61.93, SUBPART H, AND OTHER REFERENCED GUIDELINES FOR TANK FARM'S NATIONAL EMISSION STANDARDS FOR HAZARDOUS AIR POLLUTANT (NESHAP) DESIGNATED STACKS}

\subsection{INTRODUCTION}

The U.S. Environmental Protection Agency (EPA) promulgated National Emission Standards for Emissions of Radionuclides other than Radon from U.S. Department of Energy (DOE) Facilities (40 CFR 61, Subpart H) on December 15, 1989. The regulations specify procedures, equipment, and test methods that are to be used to measure radionuclide emissions from exhaust stacks that are designated as National Emission Standards for Hazardous Air Pollutant (NESHAP) stacks. Designated NESHAP stacks are those that have the potential to cause any member of the public to receive an effective dose equivalent (EDE) greater than or equal to $0.1 \mathrm{mrem} /$ year, assuming all emission controls were removed. Tank Farms currently has 33 exhaust stacks, 15 of which are designated NESHAP stacks. This document assesses the compliance status of the monitoring and sampling systems for the designated NESHAP stacks. 
This page intentionally left blank. 


\section{TANK EXHAUST COMPARISON WITH 40 CFR 61.93, SUBPART H, AND OTHER REFERENCED GUIDELINES FOR TANK FARM'S NATIONAL EMISSION STANDARDS FOR HAZARDOUS AIR POLLUTANT (NESHAP) DESIGNATED STACKS}

\subsection{PURPOSE}

The purpose of this document is to assess the compliance status of Tank Farm's designated NESHAP stacks as required by the Federal Facilities Compliance Agreement (FFCA) for Radionuclide NESHAP. The DOE and EPA Region 10 entered into the FFCA on February 7, 1994. The FFCA contains requirements for the following categories of radionuclide emission sources:

1. Previously Identified Designated Stacks

2. Remaining Registered Stacks

3. Identified Non-Registered Stacks

4. Other Potential Sources

One of the required FFCA submittals for Remaining Registered Stacks and Identified NonRegistered Stacks is an evaluation to determine which stacks should be designated NESHAP stacks (FFCA Appendix A, Section II, Paragraph 1; and Section III, Paragraph 2). The evaluation is documented in WHC-SD-WM-EMP-031 and was submitted to the EPA before the December 17, 1993 milestone. The evaluation designated nine stacks. Additional information became available after WHC-SD-WM-EMP-031 was submitted to the EPA, which necessitated the designation of an additional six stacks (for a total of 15).

This document (WHC-EP-0784) is a detailed description of existing monitoring systems and comparison with the requirements of 40 CFR 61.93 for Tank Farm's designated NESHAP stacks. This information is to be submitted to EPA by August 31, 1994 for the Remaining Registered Stacks, and by March 31, 1995 for all Identified Non-Registered Stacks (FFCA Appendix A, Section II, Paragraph 2 and Section III, Paragraph 2).

The EPA will provide the DOE with comments on this document, identifying actions necessary to achieve compliance with 40 CFR 61.93 . Within 90 days of receiving the EPAs comments, the DOE is to submit an upgrade schedule to the EPA. The upgrade schedule will become part of the FFCA once approved by the EPA. 
WHC-EP-0784

This page intentionally left blank. 
TANK EXHAUST COMPARISON WTTH 40 CFR 61.93, SUBPART H, AND OTHER REFERENCED GUIDELINES FOR TANK FARM'S NATIONAL EMISSION STANDARDS FOR HAZARDOUS AIR POLLUTANT (NESHAP) DESIGNATED STACKS

\subsection{SCOPE}

The scope of this document includes all tank farm stacks that were determined to be NESHAP stacks (with the exception of the 296-A-22 and 296-A-40 stacks). The NESHAP determinations are documented in WHC-SD-WM-EMP-031. The following stacks are evaluated in this document:

\begin{tabular}{ll} 
STACK & EACILITY \\
\hline $296-A-17$ & 241-AY/AZ Tank Farm Exhauster \\
$296-P-26$ & 241-AY/AZ Tank Farm Backup Exhauster \\
$296-A-25$ & 244-A Double Contained Receiver Tank Exhauster \\
$296-A-27$ & 241-AW Tank Farm Exhauster \\
$296-A-29$ & 241-AN Tank Farm Exhauster \\
$296-$ B-28 & 244-B Double Contained Receiver Tank Exhauster \\
$296-C-5$ & 244-CR Vault Exhauster \\
$296-P-16$ & 241-C-105/106 Tank Exhauster \\
$296-P-23$ & 241-SY Tank Farm Exhauster \\
$296-P-28$ & 241-SY Tank Farm Backup Exhauster \\
$296-S-15$ & 241-SX Tank Farm Exhauster \\
$296-S-22$ & 244-S Double Contained Receiver Tank Exhauster \\
$296-T-18$ & 244-TX Double Contained Receiver Tank Exhauster
\end{tabular}

The two designated Tank Farm stacks that are not evaluated in this document are the 296-A-22 stack (242-A evaporator vessel vent) and 296-A-40 stack (241-AP Tank Farm exhauster). These stacks are evaluated in WHC-EP-0542 and WHC-EP-0543, respectively. 
This page intentionally left blank. 


\section{TANK EXHAUST COMPARISON WITH 40 CFR 61.93, SUBPART H, AND OTHER REFERENCED GUIDELINES FOR TANK FARM'S NATIONAL EMISSION STANDARDS FOR HAZARDOUS AIR POLLUTANT (NESHAP) DESIGNATED STACKS}

\subsection{STRUCTURE OF POINT-BY-POINTS}

The format and paragraph structure used for the point-by-points are described below. The regulation and section are bold and underlined, followed by a verbatim or summarized list of the regulatory requirement(s) in small font. The applicable documentation is listed below, followed by a discussion of existing conditions and comparison with the regulation. For example:

Regulation. Section Procedural, tochnical, or other requirement taken verbatim or summarized from the regulation.

Documentation: Applicable DOE or Westinghouse Hanford Company (WHC) documentation.

Comparison: A discussion of the existing condition and comparison with the regulation.

Unlike previous point-by-point comparisons, these point-by-point comparisons do not go through each regulation from beginning to end before going on to the next regulation. Instead, the document is organized to trace the path that a reader would take if he or she were to read through 40 CFR 61.93 from beginning to end, following references to the oth regulations/standards. When one section of a regulation refers the reader to a section of a separate regulation (for example, Part 61 referring to Part 60 ) the regulation that the reader is referred to is indented. For example:

Regulation A. Section 1 Follow the requirements of Regulation B.

Requlation B Procedural, tochnical, or other requirements taken verbatim from the regulation.

Documentation: Applicable DOE or WHC documentation.

Comparison: A discussion of the existing condition and comparison with the regulation.

Requlation A. Section 2 Procedural, technical, or other requirements taken verbatim or summarized from the regulation. 
Sources referred to throughout this document, including in the appendices, are listed in Section 5.0, "References."

Where discussions/comparisons of the requirement is similar for all of the stacks, the reader is referred to Appendix $\mathbf{N}$. Appendix $\mathbf{N}$ is provided to shorten this document by eliminating repeat or duplicated discussions/comparisons. 
TANK EXHAUST COMPARISON WITH 40 CFR 61.93, SUBPART H, AND OTHER REFERENCED GUIDELINES FOR TANK FARM'S NATIONAL EMISSION STANDARDS FOR HAZARDOUS AIR POLLUTANT (NESHAP) DESIGNATED STACKS

\subsection{REFERENCES}

\section{HANFORD SITE DOCUMENTS}

\section{Supporting Documents}

RHO-CD-1092, 1980, (J. W. Cammann and C. J. Geier), 200 Area Stack Sampler-Monitor Systems Upgrade: Generic System Applications, Rockwell Hanford Operations, Richland, Washington.

SD-WM-CR-016, 1984, (J. W. Cammann), Design Criteria: FY 1985200 Area Stack Sampler-Monitor System Upgrade, Rockwell Hanford Operations, Richland, Washington.

WHC-SD-WM-EMP-031, Rev. 0, 1993, Determination of the NESHAP Status of Tank Farm Stacks Based On Calculations Using 40 CFR, Part 61, Appendix D Factors, Westinghouse Hanford Company, Richland, Washington.

WHC-SD-WM-ES-291, Rev. 1, 1994, Tank Farm Stack Sampling System Configuration and Efficiency Study, Westinghouse Hanford Company, Richland, Washington.

WHC-SD-WM-WP-147, Rev. 1, 1992, Test Procedure Upgrade Program for Ventilation Systems in Tank Farms, Westinghouse Hanford Company, Richland, Washington.

External Publications

WHC-EP-0536-1, 1993, (L. W. Vance), Quality Assurance Program Plan for Radionuclide Airborme Emissions Monitoring, Westinghouse Hanford Company, Richland, Washington.

WHC-EP-0542, 1992, (G. M. Crummel, A. K. Dasgupta, L. P. Diediker), 242-A Evaporator comparison with 40 CFR 61, Subpart $H$, and Other Referenced Guidelines for Stack 296-A-22, Westinghouse Hanford Company, Richland, Washington. 
WHC-EP-0543, 1992, (G. M. Crummel, A. K. Dasgupta, L. P. Diediker), 241-AP Tank Exhaust Comparison with 40 CFR 61, Subpart H, and Other Referenced Guidelines for Stack 296-A-40, Westinghouse Hanford Company, Richland, Washington.

WHC-EP-0573, (J. W. Schmidt), Westinghouse Hanford Company Operational Environmental Monitoring Annual Report, Westinghouse Hanford Company, Richland, Washington.

\section{Drawings}

Drawing H-2-35834, Rev. 2, 1990, Ventilation Air Flow Diagram, Tanks 105-SX, 107, 108, $109,110,112,114$.

Drawing H-2-35835, Rev. 3, 1985, Vent Plan and Details, Tanks 105, 107, 108, 109, 110, $111,1145 \mathrm{X}$.

Drawing H-2-38215, Rev. 1, 1967, Ventilation Plan and Details.

Drawing H-2-46172, Rev. 6, 1991, Ventilation, Ductwork Plan and Details, Tanks 241-S-10, $102,103,105,106,107,109$ to 112.

Drawing H-2-46785, Rev. 4, 1991, Instrument Exhaust Unit Enclosure Assembly.

Drawing H-2-62883, Rev. 3, 1987, Architectural-Structural Sections and Details.

Drawing H-2-62888, Rev. 9, 1987, 241-A-702 Ventilation System Plans Sections Details Filter Building.

Drawing H-2-70358, Rev. 5, 1984, Instrumentation Exhaust Stack Radiation Monitor.

Drawing H-2-71048,Rev. 4, 1992, Ventilation Plan and Details.

Drawing H-2-71936, Rev. 4, 1992, HVAC Equipment Plan Elevations Details.

Drawing H-2-71955, Rev. 3, 1982, Instrument Exhaust Stack Radiation Monitor.

Drawing H-2-73839, Rev. 5, 1991, HVAC Plans, Sections, and Details.

Drawing H-2-73809, Rev. 3, 1991, Instrument Exhaust Unit Enclosure Assembly, System 283.

Drawing H-2-73812, Rev. 6, 1991, Instrument Exhaust Unit Enclosure Assembly, System 1.

Drawing H-2-74913, Rev. 1, 1985, 296-5-15 Sludge Cooler Stack Monitor Installation. 
Drawing H-2-79962, Rev. 0, 1991, 296-A-17 Exhaust Stack Probe Assembly.

Drawing H-2-90906, Rev. 3, 1991, HVAC Equipment Plan and Elevations.

Drawing H-2-90908, Rev. 2, 1984, HVAC Miscellaneous Details.

Drawing H-2-90910, Rev. 2, 1984, HVAC Details.

Drawing H-2-92516, Rev. 2, 1991, Sheet 1 of 4, Filter Building Stack Monitor Installation 296-A-17.

Drawing H-2-92516, Rev. 2, 1991, Sheet 2 of 4, Filter Building Stack Monitor Installation 296-A-17.

Drawing H-2-92516, Rev. 3, 1991, Sheet 3 of 4, Filter Building Stack Monitor Installation 296-A-17.

Drawing H-2-92519, Rev. 3, 1993, Stack Monitor Installation 296-C-5.

Drawing H-2-92523, Rev. 0, 1982, 296-C-5 Stack Monitor Probe Assembly.

Drawing H-2-92567, Rev. 1, 1985, 296-P-16 Stack Monitor Installation.

Drawing H-2-92568, Rev. 0, 1985, Stack Extension and Cover Assemblies.

Drawing H-2-92569, Rev. 1, 1985, Probe Assembly Stack Sampler/Monitor.

Drawing H-2-93000, Rev. 0, 1983, Stack Assembly Portable Exhauster 1000 CFM.

Drawing H-2-93001, Rev. 2, 1984, Probe Assembly Portable Exhauster 1000 CFM.

Drawing H-2-93100, Rev. 2, 1991, $4000 \mathrm{ft}^{3} / \mathrm{min}$ Portable Exhauster Site Specifics.

Drawing H-2-93427, Rev. 4, 1993, 296-P-22/2960-P-23 Stack Monitor Installation.

Drawing H-2-93428, 296-P-23 Stack Monitor Probe Assembly.

Drawing H-2-93430, Rev. 0, 1984, Stack Extension Assembly.

Drawing H-2-95250, Rev. 1, 1985, Probe Assembly 296-S-15 Stack Sampler/Monitor.

Drawing H-2-95299, Rev. 0, 1985, 296-A-25 Stack Monitor Probe Assembly. 


\section{Correspondence}

13314-89-032, 1989, Aging Waste Off-Gas Sampling Status Report, (Memorandum from Tank Farm Process Technology Section to N. R. Kerr et al., dated April 21), Westinghouse Hanford Company, Richland, Washington.

65950-86-607, 1986, Tank 101-12 Vapor Space Radionuclide Concentrations and Partition Factors, (Internal Letter from R. T. Kimura and S. R. Johnson to D. J. Squires, dated October 14), Richland Home Office, Richland, Washington.

Gelman Sciences, 1991, Inter-Office Memorandum to Karol Butcher, October 30, RE: Versapor 3000, DOP efficiency.

\section{Procedures}

Health Physics Procedure No. 3.3.2, Rev. 1, 1994, Gaseous Effluent Monitoring System Inspection and Sample Exchange, Westinghouse Hanford Company, Richland, Washington.

Maintenance Engineering Services Maintenance Procedure 7-GN-56, Rev. 1, Airflow Capacity and Distribution Tests, Westinghouse Hanford Company, Richland, Washington.

Maintenance Engineering Services Maintenance Procedure 1202, Rev. 0, Determination of Effluent Flow For Large Stacks and/or Ducts,

WHC-IP-0718-1, Health Physics Procedures Manual, Westinghouse Hanford Company, Richland, Washington.

\section{FEDERAL AGENCY DOCUMENTS}

40 CFR 60

40 CFR 61

ANSI N13.1-1969, 1969, American National Standard Guide to Sampling Airborne Radioactive Materials in Nuclear Facilities, American National Standards, Inc., New York, New York. 
DOE/RL-93-36, 1992, Radionuclide Air Emissions Report for the Hanford Site, Calendar Year 1992, U.S. Department of Energy, Richland Field Office, Richland, Washington.

NRC NuReg/GR-006, Serial \#2145, (N. K. Anad, A. R. McFarland, F. S. Wong, C. J. Kocmound), Deposition 2.0, Nuclear Regulatory Commission, Washington, D.C. 
This page intentionally left blank. 


\section{APPENDIX A}

40 CFR 61.93, SUBPART H COMPARISON FOR 296-A-17 
This page intentionally left blank. 


\section{NESHAP COMPLIANCE FOR THE AYIAZ TANK FARM EXHAUSTER \\ STACK (296-A-17) PROVIDED BY TANK FARMS \\ FACILITY ENVIRONMENTAL ENGINEERING}

\section{Subpart H Section 61.93(a) (coe Appendix N)}

Subpart H Section 61.93(b) Radionuclide emission ratea from point sources (stacke or venta) shall be measured in accordance with the following requirements or other procedures for which EPA hes granted prior approval

Subpart H Section 61.93(b)(1) Effluent flow rate measurements aball be made using the following methods.

Subpart H Section 61.93(b)(1)(i) Reference Method 2 of Appendix A to Part 60 shall be used to determine velocity and volumetric flow rates for atacke and large vents.

Documentation: Drawing H-2-62883 Arch. Struct. Sections and Details.

Comparison: Stack 296-A-17 has an inside diameter of $44.5 \mathrm{~cm}$ (17.5 in.) and is categorized as a stack or large vent.

40 CFR 60. Appendix A. Method 2. Section 1.2 This procedure is not applicable at measurement sites which fail to meet the criteria of Method 1, Section 2.1. Neo, the method cannot be used for direct mearurement in cyclonic or swirling gas stranms; Section 2.4 of Method 1 shows how to determine cyclonic or swirling flow conditions.

40 CFR 60. Appendix A. Method 1. Section 2.1 Sampling or velocity measurement is performed at a site located at least eight stack or duct diameters downstream and two diameters upatream from any flow dieturbance such as a bend, expansion, or contraction in the stack, or from a visible flame. If nocessary, an alternative location may be eolected, at a position at least two stack or duct diametere downetream and a half diameter upetream from any flow diaturbance.

\section{Documentation: WHC-SD-WM-ES-291}

Drawing H-2-62883

Drawing H-2-62888

Comparison: The stack flow measurement location is 5.3 diameters downstream from the nearest flow disturbance (sample probe) and 18 diameters upstream from the nearest flow disturbance (top of stack), which meets the alternate location requirements. 
40 CER 60. Appendix A. Method 1. Section 2.4 Cyclonic flow may exist (1) after auch dovices as cyclones and internal demistern following venturi wcrubbers, or (2) in stacks having tangential inlots or other duct configurations which tend to induce swirling; in these instances, the presence or abeosce of cyclonic flow at the ampling location muat be dotermined.

Documentation: Drawing H-2-62883

Drawing H-2-62888

Comparison: $\quad$ Stack 296-A-17 does not have devices such as cyclones, internal demisters, or tangential inlets between the fan inlet to the stack and the stack flow measurement location.

Method 2. Section 3.3 Measure the velocity head and temperature at the traveree points specified by Mothod 1.

Documentation: Maintenance Engineering Services Maintenance Procedure 7-GN-56, Rev 1

\section{GUIDANCE/DATA SHEET FOR 241-AY/AZ EXHAUST STACK (296-A-17) FLOW MEASUREMENT}

Comparison: Based on the distances to the nearest upstream and downstream flow disturbances and Part 60, Appendix A, Method 1, Figure 1-2, 16 mearurements should be taken on each of two traverses. The referenced procedure calls for 16 measurements to be taken, but only along one traverse. The stack does not have a second flow measurement port.

Subpart H Section 61.93(b)(1)(ii) Reference Method 2A of Appendix A to Part 60 shall be used to measure flow rates through pipes and small vents.

Documentation See documentation referenced for Section 61.93 (b)(1)(i).

Comparison Stack 296-A-17 has an inside diameter of $44.5 \mathrm{~cm}(17.5 \mathrm{in}$.$) and is$ categorized as a stack or large vent; therefore, the requirements of Section 61.93(b)(1)(ii) do not apply.

Subpart H Section 61.93(b)(1)(iii) The frequency of flow rate measurements shall depend upon the variability of the effluent flow rate. For variable flow rates, continuous or frequent flow rates measurements shall be made. For relatively constant flow rates, only periodic measurements are necessary.

Documentation: RHO-CD-1092

SD-WM-CR-016

WHC-SD-WM-ES-291 
Comparison: A flow rate with a variability of less than $\pm 20 \%$ has been defined at the Hanford Site as being continuous. This criteria is specified in SD-WM-CR-016. Flow rate measurements are therefore, taken periodically (quarterly). During 1992 and 1993, the measured flow rate for this stack varied by $-14 \%$ and $+15 \%$.

Subpart H Section 61.93(b)(2) Radionuclides shall be diroctly monitored or extracted, colloctod and measured uning the following methods

Subpart H Section 61.93(b)(2)(i) Reference Method 1 of Appendix A Part 60 shall be used to select monitoring or sampling sites.

40 CFR 60. Appendix A. Method 1. Section 1.2 This method is applicable to flowing gas streams in ducts, atacks, and flues. The method cannot be ueed when (1) flow is cyclonic or swirling (ece Section 2.4); (2) a stack is amaller than about $0.30 \mathrm{~m}$ (12 in.) in diameter, or $0.071 \mathrm{~m}^{2}$ (113 in.2) croes-nectional area; or (3) the measurement site is less than two stack or duct diameters downstream or less than a half diameter upatream from a flow disturbance.

Documentation: WHC-SD-WM-ES-291

Drawing H-2-62883

Drawing H-2-62888

Comparison: This stack is $44.5 \mathrm{~cm}$ (17.5 in.) in diameter. The sampling site is located 2.2 diameters downstream from the exhaust recirculation duct outlet and 5.3 diameters upstream from the flow measurement port above roof. Stack 296-A-17 does not have devices such as cyclones, internal demisters, or tangential inlets between the fan inlet to the stack and the stack sampling locacion.

40 CFR 60. Appendix A. Method 1. Section 2.1 Sampling or velocity measurement is performed at a site located at least eight stack or duct diameters downstream and two diameters upstream from any disturbances mch a a bend, expansion, or contraction in the stack, or from a visible flame. If necessary, an alternative location may be relocted, at a position at least two stack or duct diameters downstream and a half diameter upstream from any flow disturbance.

Documentation: See documentation referenced for Method 1, Section 1.2.

Comparison: $\quad$ See comparison for Method 1, Section 1.2.

Subpart H Section 61.93(b)(2)(ii) The effluent stream shall be directly monitored continuously with an in-line detector or representative samples of the effluent stream shall be withdrawn continuously from the sampling site following the guidance presented in ANSI N13.1-1969 "Guide to Sampling Airbome Radioactive Materials in Nuclear Facilities" (including the guidance presented in Appendix A of ANSI N13.1). 


\section{ANSI N13.1-1969, Guide to Sampling Airborne Radioactive Materials in Nuclear Facilities}

ANSI N13.1-1969, Section 4.2.1.2 The sampling point ahould be a minimum of five diameters (or five times the major dimension for roctangular ducts) downstream from abrupt changes in flow direction or prominent transitions.

Documentation: WHC-SD-WM-ES-291

Drawing H-2-62883

Drawing H-2-62888

Comparison: The sampling point is located only 2.2 diameters downstream from the nearest prominent transition (exhaust recirculation outlet); however, the sampling location meets the minimum criteria of $\mathbf{4 0}$ CFR 60, Appendix A, Method 1. Moving the sample location to five duct diameters would significantly increase the sample line losses or require placement of the record sampler above the roof of the building, creating a safety hazard for personnel that service the unit.

ANSI N13.1-1969. Section 4.2.2.1 SAMPLING WTTHOUT DIFPERENTIATION OR BIAS AS TO PARTICLE SIZE AND KIND. The sampler must not fractionate by particle size or in other ways distort the phyaical and chemical properties of the airbome radionuclide conatituents.

Documentation: WHC-SD-WM-ES-291

NRC NuReg/GR-006, Serial $\$ 2145$

Comparison: Theoretical calculations of sample line losses indicate that the sampling system is biased with respect to particle sizes. Because of the relatively long sample line $3.4 \mathrm{~m}$ (11 ft), large particles (on the order of 10 micron) may not be adequately sampled. The theoretically determined sampling system particle penetration percentage is on the order of 85 percent for small particles (3.5 micron), and 10 percent for large particles. Paragraph 3.1.1 of the Configuration and Efficiency Study justifies using a 3.5 micron particle size for evaluation of sampling system efficiency.

ANSI N13.1-1969. Section 4.2.2.2 (wec Appendix N)

ANSI N13.1-1969. Section 4.2.2.3 PARTICLE SIZE FRACTIONATION DUE TO AN ISOKINETIC SAMPLING. In applications in which particle sizes may be expected to vary, it is recommendec that the sampler arrangement be deaigned to permit near isokinetic flow into the sampler entry probe.

Documentation: WHC-SD-WM-ES-291 
Comparison: The sampling system is designed to be isokinetic for a stack flow rate of $88,690 \mathrm{~L} / \mathrm{min}\left(3132 \mathrm{ft}^{3} / \mathrm{min}\right)$ and sample (and continuous air monitor [CAM]) flow rate of $120 \mathrm{~L} / \mathrm{min}\left(4.2 \mathrm{ft}^{3} / \mathrm{min}\right)$. The average sample flow rate for CY 1992 was $110 \mathrm{~L} / \mathrm{min}\left(3.8 \mathrm{ft}^{3} / \mathrm{min}\right)[54$ $\mathrm{L} / \mathrm{min}\left(1.9 \mathrm{ft}^{3} / \mathrm{min}\right)$ was the average measured record sample flow and assume average CAM flow was also $\left.54 \mathrm{~L} / \mathrm{min}\left(1.9 \mathrm{ft}^{3} / \mathrm{min}\right)\right]$. For this sample flow rate, isokinetic conditions would be achieved at a stack flow rate of $80,221 \mathrm{~L} / \mathrm{min}\left(2833 \mathrm{ft}^{3} / \mathrm{min}\right)$. The average stack flow rate for 1992 was $90,551 \mathrm{~L} / \mathrm{min}\left(3198 \mathrm{ft}^{3} / \mathrm{min}\right)$. The difference between the design flow rate and actual conditions will result in oversampling of large particles (>5 micron). The errors due to anisokinetic sampling are included in the theoretically determined sampling system particle penetration percentage discussed in ANSI N13.1-1969, Section 4.2.2.1.

\begin{abstract}
ANSI N13.1-1969, Section 4.2.2.4 SAMPLE DISTORTION DUE TO CHEMICAL REACTIONS AND RELATED EFFECTS. Extreme care muat be exercised in extracting a sumple from an airatream when the air contains chemically reactive form of radionctive isotopes. Materials to be avoided for anmpling iodine are rubber, copper, and some platics. When the air to be sumpled is nearly saturated with water vapor, condenation may occur on the collector itself. When heavy moisture loadinga are anticipated, heated ampling lines will be required to prevent condensation in the lines and to rise the collector temperature well above the dewpoint.
\end{abstract}

Documentation: Not applicable.

Comparison: This sampling system contains a silver zeolite cartridge for collecting radioactive iodine, tin, antimony, and ruthenium samples. The sampling system upstream of the silver zeolite cartridge does not contain rubber, copper, or plastic, which may absorb radioiodine or ruthenium. Although psychrometric data is not available for this stack, there are no indications that the effluent may be saturated (with water vapor) and may impact the sampling by condensing in sample lines, plugging the filter paper, or weakening the filter media. As a precaution, heat tape exists on the sample line to prevent condensation.

ANSI N13.1-1969. Section 4.3.1 (see Appendix N)

ANSIN13.1-1969. Section 4.3.2 (sce Appendix N)

ANSI N13.1-1969. Section 4.3.3 (soc Appendix N)

ANSI N13.1-1969. Section 4.3.4 (200 Appendix N)

ANSI N13.1-1969, Section 4.3.5 (see Appendix N) 
ANSI N13.1-1969. Section 5.2.2 PARTICLE COLLECTORS WTTHOUT SIGNIFICANT SIZE DIFFERENTIATION. At regular intervals and when any change is anticipated, the airborne material should be characterized as to physical and chemical nature.

Documentation: $65950-86-607$

$13314-89-032$

\section{WHC-SD-WM-EMP-031}

Comparison: The airborne effluent upstream of the HEPA filters was characterized by the first referenced letter, then further characterized by the second referenced letter to include more detailed physical and chemical analysis and a pre-HEPA particle size study. This study determined that the particle size-distribution is bimodal. The two most prominent particle sizes are 0.1 micron and 4.0 micron; where 30 percent of the particles collected were 0.1 micron and 17 percent were 4.0 micron. The airborne effluent downstream of the HEPA filters has not been characterized, and may difier significantly in terms of particle size distribution. The operation of this system has not significantly changed in a manner that would increase concentrations in the effluent since the most recent off-gas study. In fact, airborne concentrations may be lower than previously measured because the airlift circulators were shut down on the $101 \mathrm{AZ}$ and $102 \mathrm{AZ}$ tanks in August 1993 and February 1994, respectively.

\section{ANSI N13.1-1969. Section 5.2.2.1 (20e Appendix N)}

\section{ANSI N13.1-1969, Section 5,2.2.1.7 (rec Appendix N)}

ANSI N13.1-1969. Section 5.3 GASES. Airborne radionctive volutile materials and so-called "permanent" gasea such as tritium are frequently important contaminants and their aampling and colloction require tochniques and methods differing from those used in particulate esmpling.

Documentation: WHC-SD-WM-EMP-031, Rev. 0

Comparison: The potential offsite dose from radioactive iodine gas is less than 10 percent of the total potential off-site dose from this stack. Therefore, the 296-A-17 stack sampling system does not require volatile radioactive gas sampling. However, the 296-A-17 stack sampling system does contain two Silver Zeolite cartridges for collecting radioactive iodine and other gases. See Appendix $\mathrm{N}$ for description of the sampling cartridges.

ANSI N13.1-1969, Section 6.0 (see Appendix N) 
ANSI N13.1-1969. Appendix A. Section A1 Minimization of the length and bends of ample delivery lines will contribute to representative ampling.

Documentation: Drawing H-2-92516 Sheet 1 of 4

Drawing H-2-92516 Sheet 2 of 4

WHC-SD-WM-ES-291

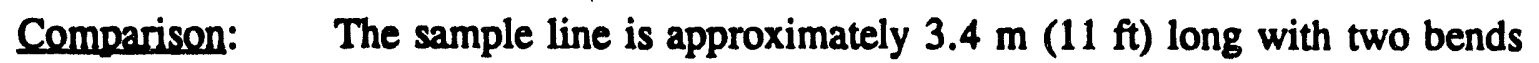
that are 45 degrees each with a minimum bend radius of $19 \mathrm{~cm}$ (7.5 in.) The sample line has an inside diameter of $1.6 \mathrm{~cm}$ (.62 in.)

ANSI N13.1-1969. Appendix A. Section A2 The distance from the last upatream disturbance to the point of aample extraction chould be a minimum of five and preferably ten or more duct diameters downstream. Sampling from a vertical run avoide atratification due to gravity eettling. Sampling as far downstream as poanible avoids moet trancient variation in airatream quality.

See response under ANSI N13.1-1969, Section 4.2.1.2.

ANSI N13.1-1969. Appendix A. Section A3.1 Velocity and flow distribution should be known for the ampling point, and particle and gascous composition should be representative.

Documentation: Maintenance Engineering Services Maintenance Procedure 7-GN-56

GUIDANCE/DATA SHEET FOR 241-A Y/AZ PRIMARY EXHAUST STACK (296-A-17) FLOW MEASUREMENT

Comparison: The particle and gaseous composition are assumed to be uniform since this is a vertical stack and the effluent should be well mixed when it reaches the sampling location (i.e., Stack flow is turbulent). The velocity distribution is shown in Figure A-1. Stack flow measurements are taken 5.3 duct diameters downstream of the sampling location. Use the following equation to convert from velocity pressure (inches water, gauge) to velocity (feet per minute).

Velocity $=4005 * \sqrt{\text { VelocityPressure }}$ 

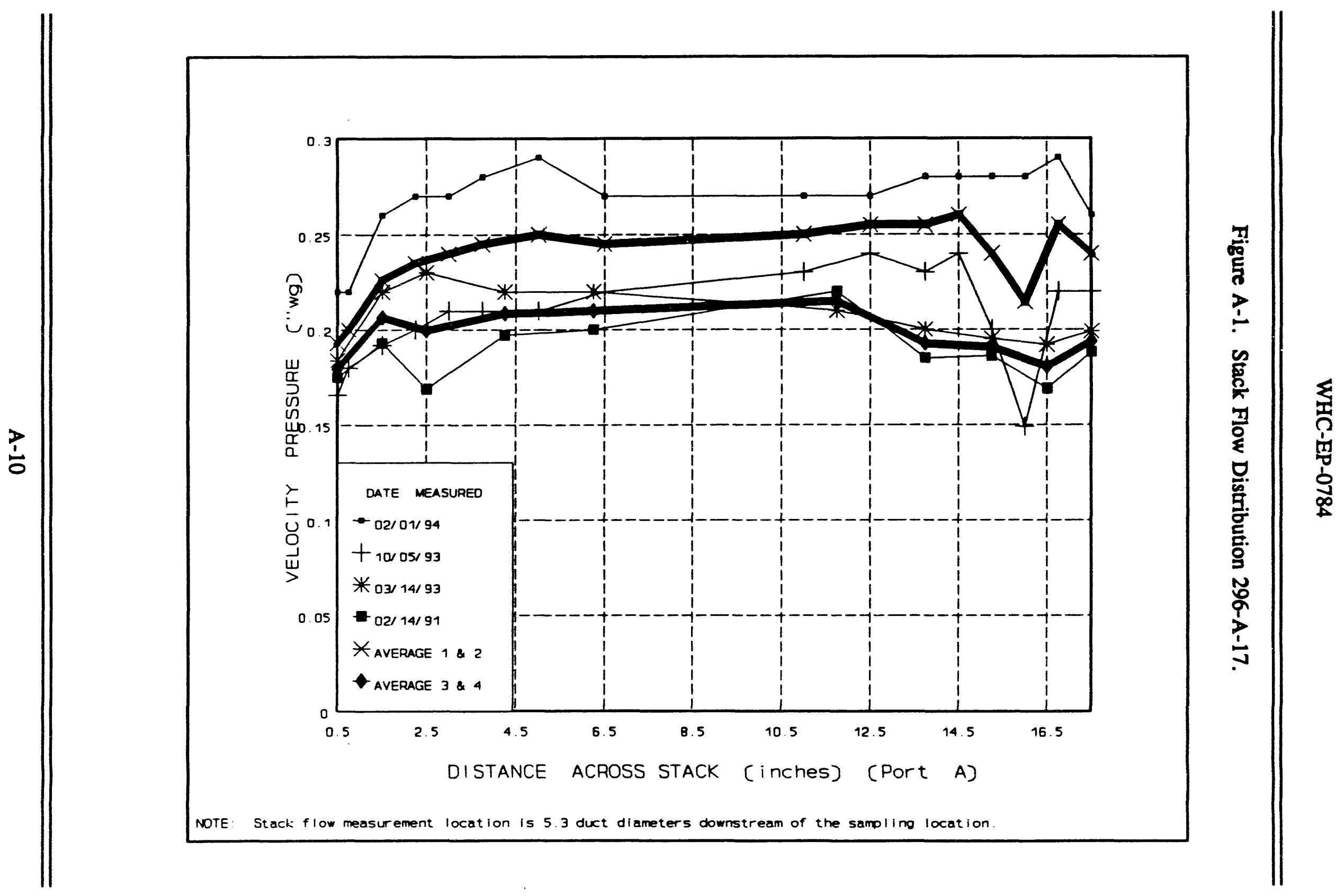
ANSI N13.1-1969. Appendix A. Section A3.2 A multiple number of withdrawal points each representing approximutely oqual areas based on the duct or atack dimensions is deairable.

Documentation: Drawing H-2-79962

Comparison: The sample probe has three nozzles that meet the requirements of Section A3.2. One of the dimensions needed to determine how the sample probe is centered in the stack could not be located on the drawings for this stack, and is relatively difficult to field verify due to the sampling probe mount being located $4.6 \mathrm{~m}$ (15 ft) above the ground in the 702 Filter Building. Because the sample probe has three nozzles and the span from the first to the third nozzle is $36.5 \mathrm{~cm}$ (14 3/8 in.) [the stack ID being $44.5 \mathrm{~cm}$ (17.5 in.)], it was assumed that the second nozzle is positioned on the centerline of the stack. To be located at the midpoints of three equal areas in the stack, the nozzles should be located at the following distances from the center of the stack $0,15.49$ and $20.19 \mathrm{~cm}(0,6.098$, and 7.947 in.) The nozzles are located at the following distances from the center of the stack $0,15.88$, and $20.64 \mathrm{~cm}(0,6.25$, and 8.125 in.). Therefore, the withdrawal points represent approximate equal areas.

ANSIN13.1-1969. Appendix A. Section A3.3 The velocity distribution scross the duct or stack should be known in order to eatublish irokinetic fiow and representative sumple points.

Documentation: Maintenance Engineering Services Maintenance Procedure 7-GN-56, Rev 1

Comparison: $\quad$ See ANSI N13.1-1969, Section 4.2.2.3 and Appendix A Section A3.1.

ANSI N13.1-1969. Appendix A. Section A3.4 Sampling probe configuration is recommended by figures in this ANSI Standard, with minimum radius bends and precisely tapered probe end edges.

Documentation: Drawing H-2-79962

Comparison: The nozzles are $1.3 \mathrm{~cm}(0.5 \mathrm{in}$.) OD with a side wall thickness of $.17 \mathrm{~cm}(0.065$ in.) $[\mathrm{ID}=.94 \mathrm{~cm}(0.37$ in. $)]$. The three nozzle bends are specified as $3 \mathrm{R}$ or $6.35 \mathrm{~cm}(2.5 \mathrm{in}$.) minimum. The bend radius begins approximately 6.35 ( $2.5 \mathrm{in}$.) from the nozzle tip. Therefore, the probe complies with the requirements listed in Figure A5 for a multiprobe sampler.

Subpart H Section 61.23(b)(2)(iii) (see Appendix N)

Subpart H Section 61.93(b)(2)(iv) (sec Appendix N) 
Subpart H Section 61.93(b)(3) (axe Appendix N)

Subpart H.Section 61.93(b)(4)(i) (coc Appendix N)

Subpart H Section 61.93(b)(4)(ii) (soc Appendix N)

Subpart H Section 61.93(b)(5) (sce Appendix N) 


\section{APPENDIX B}

40 CFR 61.93, SUBPART H COMPARISON FOR 296-P-26 
This page intentionally left blank. 


\title{
NESHAP COMPLIANCE FOR THE AY/AZ TANK FARM BACKUP EXHAUSTER STACK (296-P-20) PROVDED BY TANK FARMS FACIITY ENVIRONMENTAL ENGINEERING
}

\author{
Subpart H Section 61.23(a) (200 Appendix N)
}

Subpart H. Section 61.93(b) Radionuclide emiesion rates from point wources (atacks or ventu) shall be measured in accordanoe with the following requirements or other procodures for which EPA has granted prior approval.

Subpart H Section 61.93(b)(1) Emuent flow rate measurements ahall be made using the following mathods

Subpart H Section 61.93(b)(1)(1) Reference Mathod 2 of Appendix A to Part 60 shall be usod to determine velocity and volumetric flow rates for atacks and large vents.

Documentation: Drawing H-2-93100

Comparison: Stack 296-P-26 has an inside diameter of approximately $41 \mathrm{~cm}$ (16 in.) and falls into the category of a stack or large vent.

40 CFR 60. Appendix A. Method 2. Section 1.2 This procodure is not applicable at meenrement sites which fail to meet the critoria of Method 1, Section 2.1. Neo, the method cannot be used for direct mensurement in cyclonic or swirling gas streams; Section 2.4 of Method 1 whows how to determine cyclonic or swirling flow conditions.

40 CER 60. Appendix A. Method 1. Section 2.1 Sumpling or velocity measurement is performed at a site located at least oight atack or duct diameters downstream and two diameters upstream from any flow dieturbance such as a bend, expansion, or contraction in the stack, or from a visible flame. If neceseary, an alternative location may be selectod, at a position at least two stack or duct diameters downstream and a half diameter upatream from any flow disturbance.

\section{Documentation: WHC-SD-WM-ES-291}

Comparison: The stack flow measurement location is 5 diameters downstream from the nearest flow disturbance (diffuser plate just above fan) and 2 diameters upstream from the nearest flow disturbance (top of stack), which meets the alternate location requirements.

40 CFR 60. Appendix A. Method 1. Section 2.4 Cyclonic flow may exist (1) after such devices as cyclones and internal demisters following venturi corubbers, or (2) in stacks having tangential inlets or other duct configurations which tond to induce swirling; in these instances, the presence or abeence of cyclonic flow at the sampling location must be determined. 
Documentation: Not applicable.

Comparison: Stack 296-P-26 does not have devices such as cyclones, internal demisters, or tangential inlets between the fan inlet to the stack and the stack flow measurement location.

40 CWR 60. Appendix A. Method 2. Section 3.3 Measure the volocity haed and tomperature at the travere points epecified by Method 1.

Documentation: Maintenance Engineering Services Maintenance Procedure 7-GN-56, Rev 1

\section{GUIDANCE/DATA SHEET FOR 241-AY/AZ EXHAUST STACK (296-P-26) FLOW MEASUREMENT}

Comparison: Based on the distances to the nearest upstream and downstream flow disturbances and Figure 1-2, 16 measurements should be taken on each traverse. The referenced procedure calls for 16 measurements to be taken along each traverse.

Subpart H Section 61.93(b)(1)(ii) Reference Method 2A of Appendix A to Part 60 shall be used to measure How rates through pipes and amall vents.

Documentation: See documentation referenced for Section 61.93 (b)(1)(i).

Comparison: Stack 296-P-26 has an inside diameter of $41 \mathrm{~cm} \mathrm{(16} \mathrm{in.)} \mathrm{and} \mathrm{falls} \mathrm{into} \mathrm{the}$ category of a stack or large vent, therefore, the requirements of Section 61.93(b)(1)(ii) do not apply.

Subpart H Section 61.93(b)(1)(iii) The frequency of flow rate measurements shall depend upon the variability of the effluent how rate. For varibble tlow rutea, continuous or frequent how retes measurements shall be made. For relatively constunt flow rates only periodic measurements are necessary.

Documentation: RHO-CD-1092

SD-WM-CR-016

WHC-SD-WM-ES-291

Comparison: A flow rate with a variability of less than \pm 20 percent has been defined at the Hanford Site as being continuous. This criteria is specified in SD-WM-CR-016. The flow rate measurement is therefore, taken periodically (quarterly). During 1992, the measured flow rate for this stack varied by -5 percent and +3 percent. 
Silbpart H Section 61.93(b)(2) Radionuclides ahall be directly monitored or extractod, collectod and measured wing the following methods:

Silbpart H Seation 61.93(b)(2)(i) Reference Mathod 1 of Appendix A Part 60 shall be used to select monitoring or ampling aites.

40 CER 60. Appendix A. Method 1. Section 1.2 This mothod is applicable to flowing ges ctroams in ducts, atucke, and flues. The method cannot be used when: (1) flow is cyclonic or owirling (coe Soction 2.4); (2) a teack is analler than about $0.30 \mathrm{~m}$ (12 in.) in diametor, or $0.071 \mathrm{~m}^{2}$ (113 in. $\left.{ }^{2}\right)$ crow-wotional area; or (3) the moesurement aite is lewe than two atack or duct diamoters downstream or lew than a balf diametor upatream from a flow dieturbance.

Documentation: WHC-SD-WM-ES-291

Comparison: This stack is 16 in. in diameter. The sampling site is located 5 diameters downstream from the nearest flow disturbance (diffuser plate just above fan) and 2 diameters upstream from the nearest flow disturbance (top of stack). Stack 296-P-26 does not have devices such as cyclones, internal demisters, or tangential inlets between the fan inlet to the stack and the stack sampling location.

40 CWR 60. Appendix A. Method 1. Section 2.1 Sampling or volocity massurement is performod at a aite located at least oight atack or duct diameters downstream and two diameters upstream from any disturbances auch as a bend, expansion, or contraction in the stack, or from a visible flame. If necescary, an altornative location may be solectod, at a position at least two stack or duct diameters downetream and a half diameter upatream from any flow diaturbance.

Documentation: See documentation referenced for Method 1, Section 1.2.

Comparison: See for Method 1, Section 1.2.

Subpart H Section 61.93(b)(2)(ii) The effluent stream shall be directly monitorod continuously with an in-line detoctor or representative eamples of the eflluent stream shall be withdrawn continuously from the ampling site following the guidance presented in ANSI N13.1-1969 "Guide to Sampling Airbome Radioactive Materials in Nuclear Facilities" (including the guidance presented in Appendix A of ANSI N13.1).

\section{ANSI N13.1-1969. Guide to Sampline Airborne Radioactive Materials in Nuclear Facilities}

ANSIN13.1-1969. Section 4.2.1.2 The ampling point should be a minimum of five diameters (or five timea the major dimension for roctangular ducts) downstream from abrupt changes in flow diroction or prominent transitions.

Documentation: WHC-SD-WM-ES-291

Drawing H-2-93100 
Comparison: The sampling point is located 5 diameters downstream from the nearest prominent transition (diffuser plate just above fan).

ANSI N13.1-1969. Section 4.2.2.1 SAMPLING WTTHOUT DIFFERENTIATION OR BLAS AS TO PARTICLE SIZE AND KIND. The ampler must not fractionate by particle aize or in other ways distort the physioal and chemioal properties of the airbome radionuclide constituents.

Documentation: WHC-SD-WM-ES-291

NRC NuReg/GR-006, Serial $\$ 2145$

Comparison: Theoretical calculations of sample line losses indicate that the sampling system is biased with respect to particle sizes. The theoretically determined sampling system particle penetration percentage is on the order of 99 percent for small particles (3.5 micron), and 77 percent for large particles (10 micron). Paragraph 3.1.1 of the Configuration and Efficiency Study justifies using a 3.5 micron particle size for evaluation of sampling system efficiency.

\section{ANSI N13.1-1969. Section 4.2.2.2 (200 Appendix N)}

ANSI N13.1-1969. Section 4.2.2.3 PARTICLE SIZE FRACTIONATION DUE TO ANISOKINETIC SAMPLING. In appliantions in which particle sizes may be expected to vary, it is recommended that the eampler arrangement be designod to permit near isokinetic flow into the sumpler entry probe.

\section{Documentation: WHC-SD-WM-ES-291}

Comparison: The sampling system is designed to be isokinetic for a stack flow rate of $90,390 \mathrm{~L} / \mathrm{min}\left(3192 \mathrm{ft}^{3} / \mathrm{min}\right)$ and sample flow rate of $62 \mathrm{~L} / \mathrm{min}$ $(2.2 \mathrm{ft} / \mathrm{min})$. The average sample flow rate for CY92 was $57 \mathrm{~L} / \mathrm{min}$ $\left(2 \mathrm{ft}^{3} / \mathrm{min}\right)$. For this sample flow rate, isokinetic conditions would be achieved at a stack flow rate of $82,520 \mathrm{~L} / \mathrm{min}\left(2914 \mathrm{ft}^{3} / \mathrm{min}\right)$. The average stack flow rate for 1992 was $150,578 \mathrm{~L} / \mathrm{m}\left(5318 \mathrm{ft}^{3} / \mathrm{min}\right)$ [the difference between the ideal (isokinetic) and actual stack flow rate will result in oversampling of larger particles ( $>5$ micron)]. The errors due to anisokinetic sampling are included in the theoretically determined sampling system particle penetration percentage discussed in ANSI N13.1-1969, Section 4.2.2.1.

\footnotetext{
ANSI N13.1-1969. Section 4.2.2.4 SAMPLE DISTORTION DUE TO CHEMICAL REACTIONS AND RELATED EFPECTS. Extreme care must be exercised in extrneting a sumple from an airstream when the air contains chemically reactive forms of radioactive isotopes. Materials to be avoided for ampling iodine are rubber, copper, and some plastics. When the air to be sampled is nearly saturated with water vapor, condensation may occur on the collector itself. When heavy moisture loadings are anticipated, heated sampling lines will be required to prevent condenuation in the lines and to nise the collector temperature well above the dewpoint.
} 
Documentation: Not applicable.

Comparison: This sampling system does not contain a silver zeolite cartridge for collecting radioactive iodine, tin, antimony, and ruthenium samples. Psychrometric data has not been collected for this stack, however, there are no indications that the effluent may be saturated (with water vapor) and may impact the sampling by condensing in sample lines, plugging the filter paper, or weakening the filter media. As a precaution, heat tape exi sts on the sample line to prevent condensation.

ANSI N13.1-1969, Section 4.3.1 (soe App endix N)

ANSIN13.1-1969, Section 4.3.2 (roe Ajpendix N)

ANSLN13.1-1969. Section 4.3.3 (200 Appendix N)

ANSLN13.1-1969. Section 4.3.4 (200 Appendix N)

ANSI N13.1-1969. Section 4.3.5 (ree Appendix N)

ANSI N13.1-1969. Section 5.2.2 PARTICLE COLLECTORS WTTHOUT SIGNIFICANT SIZE DIFFERENTIATION. At regular intervals and when any change is anticipated, the airborne material ahould be chancterized as to physical and chemical nature.

\section{Documentation: $65950-86-607$}

13314-89-032

WHC-SD-WM-EMP-031

Comparison: The airborne effluent upstream of the HEPA filters was characterized for the 296-A-17 stack by the first referenced letter, then further characterized by the second referenced letter to include more detailed physical and chemical analysis as well as a pre-HEPA particle size study. This study determined that the particle size distribution is bimodal. The two most prominant particle sizes are 0.1 micron and 4.0 micron; where 30 percent of the particles collected were 0.1 micron and 17 percent were 4.0 micron. Since the 296-P-26 exhauster uses the same ducting, deentrainer, and condenser as the 296-A-17 stack, the 296-P-26 exhauster effluent should be the same. However, the airborne effluent downstream of the HEPA filters has not been characterized, and may differ significantly in terms of particle size distribution. The operation of this system has not significantly changed in a manner that would increase concentrations in the effluent since the most recent off-gas study. In fact, airborne 
concentrations may be lower than previously measured due to the airlift circulators being shut down on $101 \mathrm{AZ}$ and $102 \mathrm{AZ}$ in August 1993 and February 1994, respectively.

ANSI N13.1-1969. Section 5.2.2.1 (200 Appendix N)

ANSI N13.1-1969. Section 5.2.2.1.7 (coe Appendix N)

ANGT N13,1-1969. Section 5.3 GASES. Airbome radioactive volatile materials and so-called "permanent" gases such as tritium are frequently important contaminanta and their sampling and collection require techniques and methods differing from those used in particulate sampling.

Documentation: WHC-SD-WM-EMP-031, Rev. 0

Comparison: The potential off-site dose from radioactive iodine gas is less than 10 percent of the total potential off-site dose from this stack.

Therefore, the 296-P-26 stack sampling system does not require volatile radioactive gas sampling.

ANSI N13.1-1969. Section 6.0 (roe Appendix N)

ANSI N13.1-1969. Appendix A. Section A1 Minimization of the length and bends of ample delivery lines will contribute to representative sumpling.

Documentation: Drawing H-2-93100 Sheet 2 of 3

WHC-SD-WM-ES-291

Comparison: The sample line is approximately $2.4 \mathrm{~m}(8 \mathrm{ft})$ long with one 90 degree bend with a minimum bend radius of $4 \mathrm{~cm}$ [1.5 in.) (the actual bend radius is approximately $25.4 \mathrm{~cm}(10 \mathrm{in.})]$. The sample line has an inside diameter of $1.6 \mathrm{~cm}$ (.62 in.).

ANSI N13.1-1969. Appendix A. Section A2 The distance from the last upstream disturbance to the point of ample extraction should be a minimum of five and preferably ten or more duct diameters downstream. Sampling from a vertical run avoids stratification due to gravity settling. Sampling as far downstream as possible avoids most transient variation in airitream quality.

Comparison: $\quad$ See response to ANSI N13.1-1969, Section 4.2.1.2.

ANSI N13.1-1969. Appendix A. Section A3.1 Velocity and flow distribution ahould be known for the aampling point, and particle and gaseous composition should be representative.

Documentation: Maintenance Engineering Services Maintenance Procedure 7-GN-56, Rev 1 


\section{GUIDANCE/DATA SHEET FOR 241-AY/AZ BACKUP EXHAUST STACK (296-P-26) FLOW MEASUREMENT}

Comparison: The particle and gaseous composition is assumed to be uniform because this is a vertical stack and the effluent should be well mixed when it reaches the sampling location (i.e., stack flow is turbulent). The stack flow measurements are taken just below the sampling location. A graph of historical stack flow measurements indicates a non-uniform flow distribution across the stack (see Figures B-1 and B-2). The disturbance in the flow is believed to be from the fan diffuser plate. Use the following equation to convert from velocity pressure (inches water, gauge) to velocity (feet per minute).

Velocity $=4005 * \sqrt{\text { Velocity Pressure }}$ 
Figure B-1. Stack Flow Distribution 296-P-26-A.

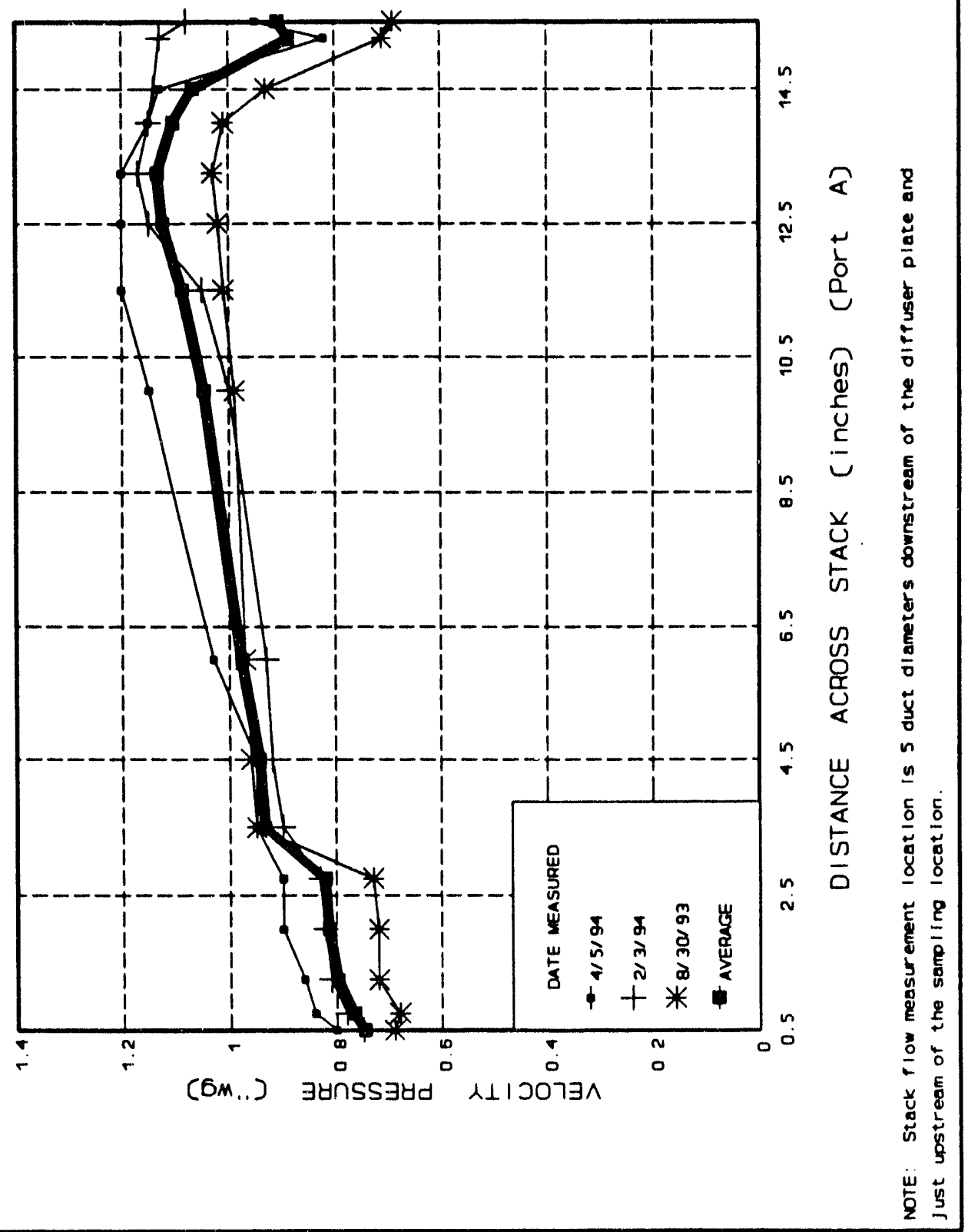

B-10 
Figure B-2. Stack Flow Distribution 296-P-26-B.

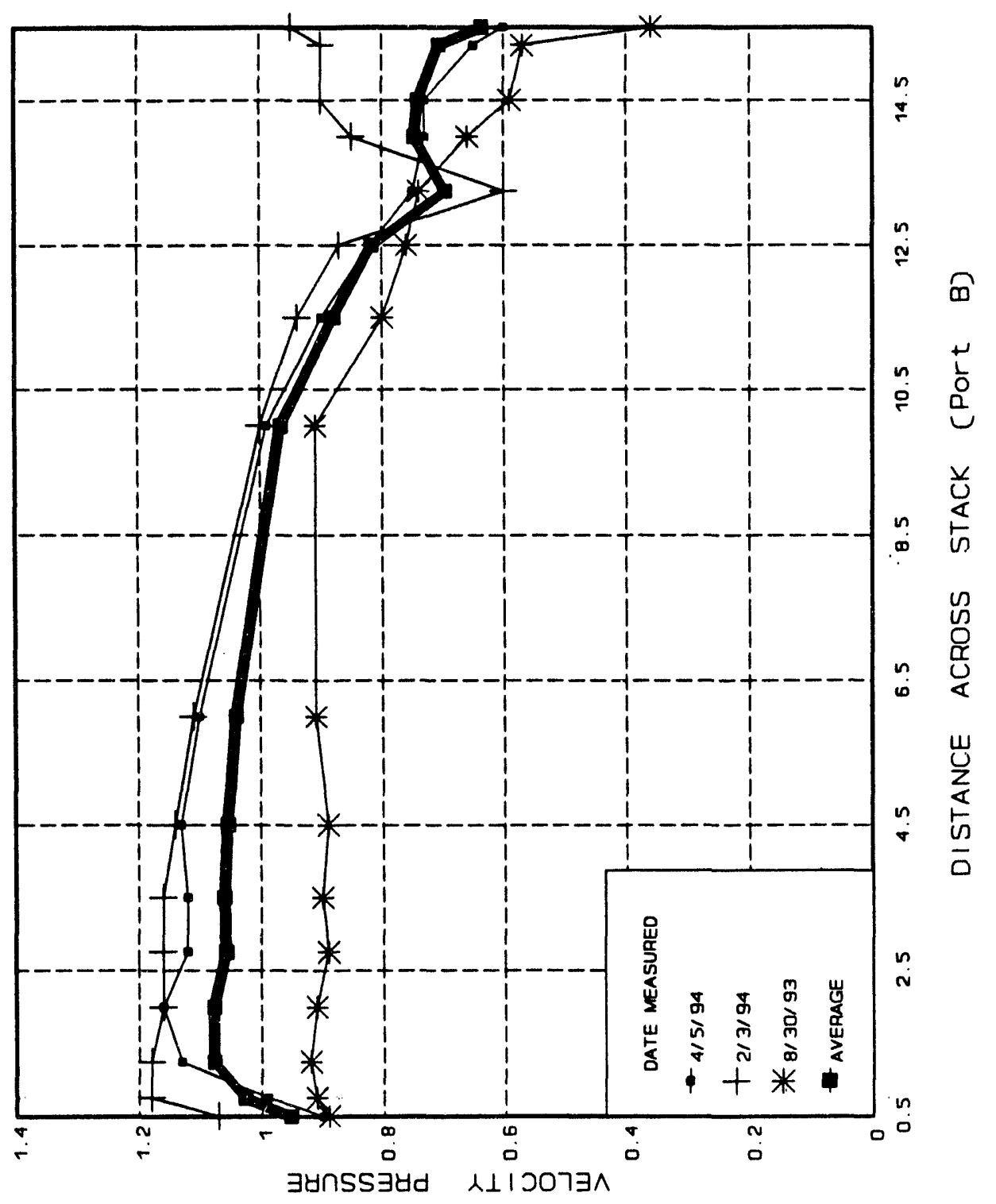


ANSI N13.1-1969. Appendix A. Section A3.2 A multiple number of withdrawal points cach representing approximately equal areas based on the duct or stack dimenuions is desirable.

Documentation: Drawing H-2-79962

Comparison: To be located at the midpoints of three equal areas in the stack, the nozzles should be located at the following distances from the center of the stack: $0,14.2,18.5 \mathrm{~cm}(0,5.58$, and 7.27 in.). The nozzles are located at the following distances from the center of the stack: 0 , $14.0,18.1 \mathrm{~cm}(0,5.50$, and $7.125 \mathrm{in}$.$) , and represent approximately$ equal areas.

ANSI N13.1-1969. Appendix A. Section A3.3 The velocity distribution across the duct or stack should be known in order to eatublish isokinetic flow and representutive sumple points.

Comparison: (see response to ANSI N13.1-1969, Section 4.2.2.3, and Appendix A, Section A3.1)

ANSI N13.1-1969. Appendix A. Section A3.4 Sampling probe configuration is recommended by figures in this ANSI Standurd, with minimum radius benda and precisely taperod probe end edges.

Documentation: Drawing H-2-79962

Comparison: The nozzles are $.8 \mathrm{~cm}(0.31 \mathrm{in}$.) OD with a side wall thickness of $.09 \mathrm{~cm}(0.035 \mathrm{in}).[\mathrm{ID}=.6 \mathrm{~cm}(0.24 \mathrm{in})$.$] . The three nozzle bends$ are specified as $3.8 \mathrm{~cm}(1.5 \mathrm{in}$.) minimum. The bend radius begins approximately $3.8 \mathrm{~cm}(1.5 \mathrm{in}$.) from the nozzle tip.

Subpart H Section 61.93(b)(2)(iii) (soc Appendix N)

Subpart H Section 61.93(b)(2)(iv) (cee Appendix N)

Subpart H Section 61.93(b)(3) (coe Appendix N)

Subpart H Section 61.93(b)(4)(i) (see Appendix N)

Subpart H Section 61.93(b)(4)(ii) (sec Appendix N)

Subpart H Section 61.93(b)(5) ( 20 Appendix N) 


\section{APPENDIX C}

40 CFR 61.93, SUBPART H COMPARISON FOR 296-A-25 
This page intentionally left blank. 
NESHAP COMPLIANCE FOR THE 244A DOUBLE CONTAINED RECEIVER TANK EXHAUSTER STACK (296-A-25) PROVIDED BY TANK FARMS FACILITY ENVIRONMENTAL ENGINEERING

\section{Subpart H Section 61.93(a) (cee Appendix N)}

Subpart H Section 61.93(b) Radionuclide emission rates from point sources (etacks or vents) shall be measured in accordanoe with the following requirements or other procedures for which EPA has granted prior approval:

Subpart H Section 61.93(b)(1) Emuent flow nute measurements shall be made using the following methods:

Subpart H Section 61.93(b)(1)(i) Reference Method 2 of Appendix A to Part 60 shall be used to determine velocity and volumetric flow rates for stacks and large vents.

\section{Documentation: Drawing H-2-38215}

Comparison: Stack 296-A-25 has an inside diameter of $10.2 \mathrm{~cm} \mathrm{(4.03} \mathrm{in.)} \mathrm{and} \mathrm{falls} \mathrm{into}$ the category of a small stack or duct, therefore, Method $2 \mathrm{C}$ should be used.

40 CFR 60. Appendix A. Method 2C. Section 1.1.1 The applicability of this method is identical to Method 2, except this method is limited to stationary source stacks or ducts loss than about $0.30 \mathrm{~m}$ (12 in.) in diameter or $0.071 \mathrm{~m}^{3}\left(113 \mathrm{in} .{ }^{2}\right)$ in crose-ecctional area, but equal to or

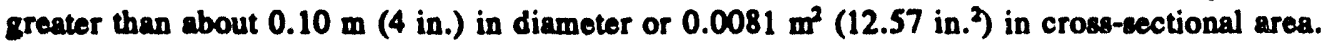

Comparison: See documentation/discussion referenced in Subpart H, Section 61.93(b)(1)(i).

40 CFR 60. Appendix A. Method 2C. Section 3.0 Follow the general procedures in Section 3 of Method 2, except conduct the measurements at the traverse points specified in Method 1A.

40 CFR 60. Appendix A. Method 1A. Section 2.1.1 Select a PM sampling site located preferably at least 8 equivalent stack or duct diameters downstream and 10 equivalent diameters upstream from any flow disturbances such as bends, expansions, or contractions in the stack, or from a visible flame. Next, locate the velocity measurement site 8 equivalent diameters downstream of the PM sampling site. If such locations are not available, eclect an alternative PM sampling site that is at least 2 equivalent stack or duct diameters downstream and $2 \frac{1}{2}$ diameters upstream from any flow disturbance. Then locate the velocity measurement site 2 equivalent diameters downstream from the PM sampling site.

Documentation: WHC-SD-WM-ES-291, Rev. 1

Field walkdown 
Comparison: The stack flow measurement location is 8 diameters downstream from the nearest flow disturbance (fan inlet to stack) and 6.5 diameters upstream from the nearest flow disturbance (sampling location).

40 CER 60. Appendix A. Method 1A. Section 2.2.2 Une Figure 1-2 of Method 1 to determine the number of traveree points, following the same procedure used for PM eampling traverses a described in Section 2.1.1 of Method 1.

Documentation: Guidance/Data Sheet for 244-A DCRT Exhaust Stack (296-A-25) Flow Measurement

Comparison: Figure 1-2 calls for 8 measurements to be taken along each traverse. The Guidance/Data Sheet also calls for 8 measurements. This stack only has one traverse, however, the traverse is in the same plane as the fan inlet to the stack and the sampling probe.

Subpart H Section 61.93(b)(1)(ii) Reference Method 2A of Appendix A to Part 60 shall be used to measure flow rates through pipes and emall vents.

Comparison: See response to Subpart H Section 61.93 (b)(1)(i).

Subpart H Section 61.93(b)(1)(iii) The frequency of flow nate measurements shall depend upon the variability of the effluent flow rate. For variable flow rates, continuous or frequent flow rates measurements shall be made. For relatively constant flow rates, only periodic measurements are neceasury.

\section{Documentation: RHO-CD-1092}

SD-WM-CR-016

WHC-SD-WM-ES-291

Maintenance Engineering Services Maintenance Procedure 7-GN-56, Rev 1

Comparison: A flow rate with a variability of less than \pm 20 percent has been defined at the Hanford Site as being continuous. This criteria is specified in SD-WM-CR-016. The flow rate measurement is therefore, taken periodically (quarterly). During 1991, the measured flow rate for this stack varied by -4 percent and +8 percent. Stack flow measurements have not been taken since 1991 because the exhauster has not been in operation.

Subpart H Section 61.93(b)(2) Radionuclides shall be directly monitored or extracted, collected and measured using the following methods:

Subpart H Section 61.93(b)(2)(i) Reference Method 1 of Appendix A, Part 60 shall be used to select monitoring or sampling sites. 
40 CER 60. Appendix A. Method 1. Section 1.2 This method is applicable to flowing gas atreams in ducts, stacks, and flues. The method cannot be used when: (1) flow is cyclonic or awirling (eee Section 2.4), (2) a ateck is amaller than about 0.30 meter (12 in.) in diametor, or $0.071 \mathrm{~m} 2(113 \mathrm{in} .2)$ crows coctional area, or (3) the measurement site is lose than two atack or duct diameters downatream or lous than a half diametor upatream from a flow disturbance.

\section{Documentation: Drawing H-2-38215.}

Comparison: The stack is only 4 inches in diameter, therefore, Method $1 \mathrm{~A}$ must be used.

40 CFR 60. Appendix A. Method 1A. Section 1.1 The applicability and principle of this method are identical to Method 1, except that this method's applicability is limited to stacks or ducts lase than about 0.30 motor $(12 \mathrm{in}$.$) in diameter or 0.071 \mathrm{~m}^{2}\left(113 \mathrm{in.}{ }^{2}\right)$ in crose-ectional area, but equal to or grealter than about 0.10 meter (4 in.) in diameter or $0.0081 \mathrm{~m}^{2}(12.57 \mathrm{in.}$ ) in croseecctional area.

\section{Documentation: Drawing H-2-38215.}

Comparison: This stack is 4 inches in diameter.

40 CER 60. Appendix A. Method 1A. Section 2.1.1 Select a PM sampling site located preforably at least 8 equivalent stack or duct diametors downstream and 10 equivalent diameters upstream from any flow disturbances such as bends, expansions, or contractions in the atack, or from a visible flame. Next, locate the velocity measurement site 8 equivalent diametere downstream of the PM anmpling site. If such locations are not available, eelect an alternative PM campling site that is at loant 2 equivalent atack or duct diameters downstream and $21 / 2$ diameters upetream from any flow disturbance. Then locate the velocity measurement site 2 equivalent diameters downetream from the PM campling site.

\section{Documentation: WHC-SD-WM-ES-291, Rev. 1}

Comparison: The PM sampling site is located 14.5 diameters downstream from the nearest flow disturbance (fan inlet to stack) and 4.5 diameters upstream from the nearest flow disturbance (top of stack).

Subpart H Section 61.93(b)(2)(ii) The effluent stream shall be directly monitored continuously with an in-line detector or representative samples of the effluent stream shall be withdrawn continuously from the sampling site following the guidance presented in ANSI N13.1-1969 "Guide to Sampling Airbome Radioactive Materials in Nuclear Facilities" (including the guidance presented in Appendix A of ANSI N13.1).

\section{ANSI N13.1-1962. Guide to Sampling Airborne Radioactive Materials in Nuclear Facilities}

ANSI N13.1-1969. Section 4.2.1.2 The sampling point should be a minimum of 5 diameters (or five times the major dimension for rectangular ducts) downstream from abrupt changes in flow direction or prominent transitions. 
Documentation: WHC-SD-WM-ES-291

Drawing H-2-38215

Comparison: The sampling point is located 13.5 diameters downstream from the nearest prominent transition (fan inlet to stack).

ANSI N13.1-1969. Section 4.2.2.1 SAMPLING WTTHOUT DIFFERENTIATION OR BIAS AS TO PARTICLE SIZE AND KIND. The sampler muat not fractionate by particle size or in other ways distort the physical and chemical propertien of the airbome radionuclide conatituents.

Documentation: WHC-SD-WM-ES-291

NRC NuReg/GR-006, Serial $\$ 2145$

Comparison: Theoretical calculations of sample line losses indicate that the sampling system is biased with respect to particle sizes. The theoretically determined sampling system particle penetration percentage is on the order of 94 percent for small particles (3.5 micron), and 68 percent for large particles (10 micron). Paragraph 3.1.1 of the Configuration and Efficiency Study justifies using a 3.5 micron particle size for evaluation of sampling system efficiency.

\section{ANSI N13.1-1969. Section 4.2.2.2. (100 Appendix N)}

ANSI N13.1-1969. Section 4.2.2.3 PARTICLE SIZE FRACTIONATION DUE TO ANISOKINETIC SAMPLING. In applications in which particle sizes may be expected to vary, it is recommended that the sampler arrangement be deaigned to permit near isokinetic tow into the ampler entry probe.

Documentation: WHC-SD-WM-ES-291

Comparison: The sampling system is designed to be isokinetic for a stack flow rate of $3230 \mathrm{~L} / \mathrm{min}\left(144 \mathrm{ft}^{3} / \mathrm{min}\right)$ and sample flow rate of $60 \mathrm{~L} / \mathrm{min}$ $\left(2.2 \mathrm{ft}^{3} / \mathrm{min}\right)$. The average sample flow rate for CY91 was $53.8 \mathrm{~L} / \mathrm{min}\left(1.9 \mathrm{ft}^{3} / \mathrm{min}\right)$. For this sample flow rate, isokinetic conditions would be achieved at a stack flow rate of $3510 \mathrm{~L} / \mathrm{min}$ $\left(124 \mathrm{ft}^{3} / \mathrm{min}\right)$. The average stack flow rate for 1991 was $5240 \mathrm{~L} / \mathrm{min}$ $\left(185 \mathrm{ft}^{3} / \mathrm{min}\right.$ ) (the difference between the ideal (isokinetic) and actual stack flow rate will result in oversampling of larger particles (>5 micron)]. The errors due to anisokinetic sampling are included in the theoretically determined sampling system particle penetration percentage discussed in ANSI N13.1-1969, Section 4.2.2.1. 
ANSI N13.1-1969. Section 4.2.2.4 SAMPLE DISTORTION DUE TO CHEMICAL REACTIONS AND RELATED BFFECTS. Bxtrume are muat be exercised in extructing a umple from an aintream when the air contuin ohemically reactive forms of radionotive ieotopes. Materials to be avoided for ampling iodine are rubber, copper, and some plation. When the air to be campled is nearly saturatod with water vapor, condensation may occur on the collector itealf. When heavy moisture losdinge are anticipated, heated sumpling lines will be required to prevent condenation in the lines and $t 0$ rive the collector temperature well above the dewpoint.

Documentation: None.

Comparison: Psychrometric data has not been collected for this stack, however, there are no indications that the effluent may be saturated (with water vapor) and may impact the sampling by condensing in sample lines, plugging the filter paper, or weakening the filter media. As a precaution, heat tape exists on the sample line to prevent condensation.

ANSI N13.1-1969. Section 4.3.1 (coe Appendix N)

ANSI N13.1-1969. Section 4.3.2 (soe Appendix N)

ANSI N13.1-1969. Section 4.3.3 (noe Appendix N)

ANSI N13.1-1969. Section 4.3.4 (200 Appendix N)

ANSI N13.1-1969. Section 4.3.5 (coe Appendix N)

ANSI N13.1-1969. Section 5.2.2 PARTICLE COLLECTORS WTTHOUT SIGNIFICANT SIZE DIFFERENTIATION. At regular intervals and when any change is anticipated, the airborne material should be characterized as to phyeical and chemical nature.

Documentation: WHC-SD-WM-EMP-031

Comparison: Several different waste streams (ie. from different tank farms and facilities) could be transferred through this facility. The airborne material has not been characterized as to physical and chemical nature.

ANSI N13.1-1969. Section 5.2.2.1 (sec Appendix N)

ANSI N13.1-1969. Section 5.2.2.1.7 (soc Appendix N)

ANSI N13.1-1969. Section 5.3 GASES. Airbome radioactive volatile materials and ro-called "permanent" gases such as tritium are frequently important contaminants and their sampling and collection require techniques and methods differing from those used in particulate sampling.

Documentation: WHC-SD-WM-EMP-031, Rev. 0 
Comparison: The potential offsite dose from radioactive ruthenium, rhodium and iodine gas is less than 10 percent of the total potential off-site dose from this stack. Therefore, the 296-A-25 stack sampling system does not require volatile radioactive gas sampling.

\section{ANSI N13.1-1969. Section 6.0 (100 Appendix N)}

ANSI N13.1-1969. Appendix A. Section A1 Minimization of the length and bende of umple delivery lines will contribute to representative mempling.

Documentation: Drawing H-2-38215

WHC-SD-WM-ES-291

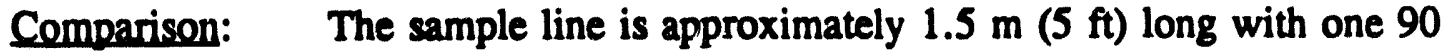
degree bend with a minimum design bend radius of $10 *$ tubing diameter. The sample line has an inside diameter of $1.6 \mathrm{~cm}(.62 \mathrm{in}$.

ANSI N13.1-1969. Appendix A. Section A2 The distance from the lest upatream disturbance to the point of ample extraction ahould be a minimum of 5 and preferably 10 or more duct diameter downatream. Sampling from a vertical run avoide atratification due to gravity eetling. Sampling as far downatream as possible avoids most transient variation in airstream quality.

Comparison: See response to ANSI N13.1-1969, Section 4.2.1.2.

ANSI N13.1-1969. Appendix A. Section A3.1 Velocity and flow distribution thould be known for the sampling point, and particle and gaseous composition should be representative.

Documentation: Maintenance Engineering Services Maintenance Procedure 7-GN-56, Rev 1

\section{GUIDANCE/DATA SHEET FOR 241-AY/AZ BACKUP EXHAUST STACK (296-A-25) FLOW MEASUREMENT.}

Comparison: The particle and gaseous composition are assumed to be uniform since this is a vertical stack and the effluent should be well mixed when it reaches the sampling location (ie. stack flow is turbulent). The stack flow measurements are taken 5.5 duct diameters upstream of the sampling location. Stack flow distribution data was not available for this stack.

\footnotetext{
ANSI N13.1-1969. Appendix A. Section A3.2 A multiple number of withdrawal points each representing approximately equal areas based on the duct or stack dimensions is desirable.
}

Documentation: Drawing H-2-95299 
Comparison: The stack has an inside diameter of $10.24 \mathrm{~cm}(4.03 \mathrm{in.})$. A minimum of one probe is required by ANSI Section A3.2. The stack contains two probes; one for the record sample and the other for the Beta/Gamma CAM. Each probe is located approximately $1.3 \mathrm{~cm}$ $(1 / 2 \mathrm{in.})$ off of the centerline of the stack.

ANSI N13.1-1969. Appendix A. Section A3.3 The velocity distribution acrose the duct or atack should be known to extablinh isokinetic flow and representative anmple points.

Comparison: (see response to ANSI N13.1 Section 4.2.2.3, and Appendix A Section A3.1).

ANSI N13.1-1969. Appendix.A. Section A3.4 Sempling probe configuration is recommendod by figures in this ANSI Standard, with minimum radius bende and precisely tuperod probe end odges.

Documentation: Drawing H-2-95299

Comparison: The nozzles are $1.59 \mathrm{~cm}(0.625 \mathrm{in}$.) OD with a side wall thickness of $0.17 \mathrm{~cm}(0.065 \mathrm{in}$.$) [ID =1.3 \mathrm{~cm}(0.5 \mathrm{in}$.$) ]. The nozzle bend is$ specified as $6.4 \mathrm{~cm}(2.5 \mathrm{in}$.$) minimum.$

Subpart H. Section 61.93(b)(2)(iii) (oce Appendix N)

Subpart H Section 61.93(b)(2)(iv) (see Appendix N)

Subpart H. Section 61.23(b)(3) (sec Appendix N)

Subpart H Section 61.93(b)(4)(i) (roc Appendix N)

Subpart H. Section 61.23(b)(4)(ii) (soc Appendix N)

Subpart H Section 61.93(b)(5) (sec Appendix N) 
This page intentionally left blank. 
WHC-EP-0784

APPENDIX D

40 CFR 61.93, SUBPART H COMPARISON FOR 296-A-27

D-1 
This page intentionally left blank.

\section{D-2}




\section{NESHAP COMPLIANCE FOR THE 241-AW TANK FARM EXHAUSTER \\ STACK (296-A-27) PROVIDED BY TANK FARMS \\ FACILITY ENVIRONMENTAL ENGINEERING}

\section{Subpart H Section 61.93(a) (200 Appendix N)}

Subpart H Section 61.93(b) Radionuclide emiseion rates from point sources (atacks or vents) shall be measured in acoordance with the following requirements or other procedures for which EPA has granted prior approval:

Subpart H Section 61.93(b)(1) Emuent tow rate measurements shall be made using the following methods:

Subpart H Section 61.93(b)(1)(i) Reference Method 2 of Appendix A to Part 60 ahall be used to determine velocity and volumetric flow ratea for atacks and large vents.

Documentation: Drawing H-2-70358

Comparison: Stack 296-A-27 has an inside diameter of $25.4 \mathrm{~cm}$ (10 in.) and falls into the category of a small stack or duct, therefore, Method $2 \mathrm{C}$ should be used.

40 CFR 60. Appendix A. Method 2C. Section 1.1.1 The applicability of this method is identical to Method 2, except this method is limited to stationary wource stacks or ducts less than about $0.30 \mathrm{~m}$ (12 in.) in diemeter or $0.071 \mathrm{~m}^{3}\left(113 \mathrm{in} .^{2}\right)$ in croes-eectional area, but equal to or greater than about $0.10 \mathrm{~m}\left(4 \mathrm{in}\right.$.) in diameter or $0.0081 \mathrm{~m}^{2}\left(12.57 \mathrm{in}^{2}{ }^{2}\right)$ in crome-sectional area.

Comparison: See documentation/discussion referenced in Subpart H, Section 61.93(b)(1)(i).

40 CFR 60. Appendix A. Method 2C. Section 3.0 Follow the general procedures in Section 3 of Method 2, except conduct the meanurements at the traveree points specified in Method $1 \mathrm{~A}$.

40 CFR 60. Appendix A. Method 1A. Section 2.1.1 Select a PM rampling site located preferably at least 8 equivalent stack or duct diameters downatream and 10 equivalent diameters upstream from any flow disturbances such as bends, expansions, or contractions in the stack, or from a visible flame. Next, locate the velocity measurement site 8 equivalent diameters downstream of the PM ampling site. If such locations are not available, select an alternative PM eampling site that' is at least 2 equivalent stack or duct diameters downstream and $21 / 2$ diameters upstream from any flow disturbance. Then locate the velocity measurement site 2 equivalent diameters downatream from the PM sampling site.

Documentation: WHC-SD-WM-ES-291, Rev. 1

Field walkdown

Comparison: The stack flow measurement location is 5 diameters downstream from the nearest flow disturbance (fan inlets to 
stack) and 1.5 diameters upstream from the nearest flow

disturbance (sampling location).

40 CFR 60. Appendix A. Method 1A. Section 2.2.2 Use Figure 1-2 of Method 1 to determine the number of traveree points, following the eame procedure used for PM sampling traverees as described in Section 2.2.1 of Method 1.

Documentation: Guidance/Data Sheet for 241-AW Exhaust Stack (296-A-27) Flow Measurement

Comparison: Figure 1-2 calls for 16 measurements to be taken along each traverse. The Guidance/Data Sheet also calls for 16 measurements.

Subpart H Section 61.93(b)(1)(ii) Reference Method 2A of Appendix A to Part 60 shall be used to measure flow rates through pipes and small vents.

Comparison: See response to Section 61.93 (b)(1)(i).

Subpart H Section 61.93(b)(1)(iii) The frequency of flow rate measurements shall depend upon the variability of the efluent flow rate. For variable flow rates, continuous or frequent tlow rates measurements shall be made. For relatively constant flow rates only periodic measurements are necessary.

Documentation: RHO-CD-1092

SD-WM-CR-016

WHC-SD-WM-ES-291

Comparison: A flow rate with a variability of less than \pm 20 percent has been defined at the Hanford Site as being continuous. This criteria is specified in SD-WM-CR-016. The flow rate measurement is therefore, taken periodically (quarterly). During 1991, 1992, and 1993, the measured flow rate for this stack varied by 12 percent and +19 percent.

Subpart H Section 61.93(b)(2) Radionuclides shall be directly monitored or extracted, collected and measured using the following methoda:

Subpart H Section 61.93(b)(2)(i) Reference Method 1 of Appendix A Part 60 shall be used to select monitoring or sampling sites.

40 CFR 60. Appendix A. Method 1. Section 1.2 This method is applicable to flowing gas streams in ducts, stacks, and flues. The method cannot be used when: (1) flow is cyclonic or swirling (see Section 2.4), (2) a stack is smaller than about 0.30 meter (12 in.) in diameter, or $0.071 \mathrm{~m} 2(113 \mathrm{in} .2)$ cross sectional area, or (3) the measurement site is less than two stack or duct diameters downstream or less than a half diameter upstream from a flow disturbance. 


\section{Documentation: Drawing H-2-90906.}

Comparison: The stack is 10 inches in diameter, therefore, Method $1 \mathrm{~A}$ must be used.

40 CFR 60. Appendix A. Method 1A. Section 1.1 The applicability and principle of this method are identical to Method 1, except that this method's applicability is limited to stacks or ducts lese then about 0.30 meter $\left(12 \mathrm{in}\right.$.) in diameter or $0.071 \mathrm{~m}^{2}\left(113 \mathrm{in}^{2}\right)$ in crose-eectional area, but equal to or greater than about 0.10 meter $\left(4\right.$ in.) in diameter or $0.0081 \mathrm{~m}^{2}\left(12.57 \mathrm{in}^{2}\right)$ in crosscectional area.

\section{Documentation: Drawing H-2-90906.}

Comparison: This stack is 10 inches in diameter.

40 CFR 60. Appendix A. Method 1A. Section 2.1.1 Select a PM sampling site located preferably at least 8 equivalent stack or duct diameters downstream and 10 equivalent diameters upatream from any flow diaturbances auch as bends, expansions, or contractions in the atack, or from a vicible flame. Next, locate the velocity meanurement site 8 equivalent diameters downstream of the PM sampling site. If such locations are not available, select an alternative PM sampling site that is at least 2 equivalent stack or duct diameters downstream and $21 / 2$ diameters upstream from any flow disturbance. Then locate the velocity measurement site 2 equivalent diameters downstream from the PM sampling site.

Documentation: WHC-SD-WM-ES-291, Rev. 1

$$
\text { Drawing H-2-90906. }
$$

Comparison: The PM sampling site is located 10 diameters downstream from the nearest flow disturbance (fan inlet to stack) and 6 diameters upstream from the nearest flow disturbance (top of stack).

Subpart H Section 61.93(b)(2)(ii) The effluent atream sthall be directly monitored continuously with an in-line detector or representative samples of the efluent stream shall be withdrawn continuously from the sampling site following the guidance presented in ANSI N13.1-1969 "Guide to Sampling Airbome Radioactive Materials in Nuclear Facilities" (including the guidance presented in Appendix A of ANSI N13.1).

\section{ANSI N13.1-1969, Guide to Sampling Airborne Radioactive Materials in Nuclear Facilities}

ANSI N13.1-1969. Section 4.2.1.2 The sampling point should be a minimum of five diameters (or five times the major dimension for rectangular ducts) downstream from abrupt changes in flow direction or prominent transitions.

Documentation: WHC-SD-WM-ES-291

Drawing H-2-90906 
Comparison: The sampling point is located 6.5 diameters downstream from the nearest prominent transition (fan inlets to stack).

ANSI N13.1-1969. Section 4.2.2.1 SAMPLING WTTHOUT DIPFERENTIATION OR BIAS AS TO PARTICLE SIZE AND KIND. The sampler muat not fractionate by particle size or in other waye distort the physical and chemical properties of the airbome radionuclide constituents.

Documentation: WHC-SD-WM-ES-291

NRC NuReg/GR-006, Serial \#2145, March 8, 1993

Comparison: Theoretical calculations of sample line losses indicate that the sampling system is biased with respect to particle sizes. The theoretically determined sampling system particle penetration percentage is on the order of 75 percent for small particles (3.5 micron), and 1 percent for large particles (10 micron). Paragraph 3.1.1 of the Configuration and Efficiency Study justifies using a 3.5 micron particle size for evaluation of sampling system efficiency.

\section{ANSI N13.1-1969. Section 4.2.2.2 (20e Appendix N)}

ANSI N13.1-1969. Section 4.2.2.3 PARTICLE SIZE FRACTIONATION DUE TO ANISOKINETIC SAMPLING. In application in which particle size may be expected to vary, it is recommended that the aumpler arrangement be deaigned to permit near isokinetic flow into the sampler entry probe.

\section{Documentation: WHC-SD-WM-ES-291}

Comparison: The sampling system is designed to be isokinetic for a stack flow rate of $16,500 \mathrm{~L} / \mathrm{min}\left(586 \mathrm{ft}^{3} / \mathrm{min}\right)$ and sample flow rate of $62 \mathrm{~L} / \mathrm{min}$ $\left(2.2 \mathrm{ft}^{3} / \mathrm{min}\right)$. The average sample flow rate for CY92 was $62 \mathrm{~L} / \mathrm{min}$ $\left(2.0 \mathrm{ft}^{3} / \mathrm{min}\right)$. For this sample flow rate, isokinetic conditions would be achieved at a stack flow rate of $15,092 \mathrm{~L} / \mathrm{min}\left(533 \mathrm{ft}^{3} / \mathrm{min}\right)$. The average stack flow rate for 1992 was $29,800 \mathrm{~L} / \mathrm{min}\left(1055 \mathrm{ft}^{3} / \mathrm{min}\right)$ [the difference between the ideal (isokinetic) and actual stack flow rate will result in oversampling of larger particles ( $>5$ micron)]. The errors due to anisokinetic sampling are included in the theoretically determined sampling system particle penetration percentage discussed in ANSI N13.1-1969, Section 4.2.2.1.

ANSI N13.1-1969. Section 4.2.2.4 SAMPLE DISTORTION DUE TO CHEMICAL REACTIONS AND RELATED EFFECTS. Extreme care must be exercised in extracting a sumple from an airstream when the air contains chemically reactive forms of radioactive isotopes. Materials to be avoided for ampling iodine are rubber, copper, and some plastics. When the air to be sampled is nearly saturated with water vapor, condensation may occur on the collector itelf. When heavy moisture loadings are anticipated, heated sampling lines will be required to prevent condensation in the lines and to raise the collector temperature well above the dewpoint. 
Documentation: Not applicable.

Comparison: This sampling system contains a Silver Zeolite cartridge for the purpose of collecting radioactive iodine, tin, antimony, and ruthenium. The sampling system upstream of the silver zeolite cartridge contains a $20.3 \mathrm{~cm}(8 \mathrm{in}$.) section of rubber tubing but does not contain copper or plastic. Psychrometric data has been collected for this stack. The data indicates that the dew point of the effluent is approximately 60 degrees $\mathrm{F}$. However, there are no indications that the effluent may be saturated (with water vapor) and may impact the sampling by condensing in sample lines, plugging the filter paper, or weakening the filter media. As a precaution, heat tape exists on the sample line to prevent condensation.

\title{
ANSI N13.1-1969, Section 4.3.1 (ree Appendix N)
}

ANSI N13.1-1969. Section 4.3.2 (1ec Appendix N)

ANSI N13.1-1969. Section 4.3.3 (ree Appendix N)

ANSI N13.1-1969. Section 4.3.4 (100e Appendix N)

ANSIN13.1-1969. Section 4.3.5 (10ec Appendix N)

ANSI N13.1-1969. Section 5.2.2 PARTICLE COLLECTORS WITHOUT SIGNIFICANT SIZE DIFFERENTIATION. At regular intervals and when any change is anticipated, the airbome material should be characterized as to physical and chemical nature.

\section{Documentation: WHC-SD-WM-EMP-031}

Comparison: The airborne effluent from this stack has not been characterized.

ANSI N13.1-1969. Section 5.2.2.1 (sec Appendix N)

ANSI N13.1-1969. Section 5.2.2.1.7 (2ec Appendix N)

\begin{abstract}
ANSI N13.1-1969. Section 5.3 GASES. Aiborne radioactive volatile materials and so-called "permanent" gases such as tritium are frequently important contaminants and their ampling and collection require techniques and methods differing from those used in particulate sampling.
\end{abstract}

Documentation: WHC-SD-WM-EMP-031, Rev. 0

Comparison: The potential offsite dose from radioactive iodine gas is less than 10 percent of the total potential off-site dose from this stack. Therefore, the 296-A-27 stack sampling system does not require volatile radioactive gas sampling. However, the 296-A-27 stack 
sampling system does contain two Silver Zeolite cartridges. See Appendix $\mathbf{N}$ for description of the sampling cartridges.

ANSI N13.1-1969. Section 6.0 (100 Appendix N)

ANSI N13.1-1969. Appendix A. Section Al Minimization of the length and bends of ample delivery lines will contribute to representative sampling.

\title{
Documentation: WHC-SD-WM-ES-291
}

Comparison: The sample line is approximately $3.3 \mathrm{~m}$ (10.9 ft) long with one 90 degree bend with a design bend radius of $91 \mathrm{~cm}(36 \mathrm{in}$.). The sample line has an inside diameter of $0.94 \mathrm{~cm}(0.37 \mathrm{in}$.$) .$

\begin{abstract}
ANSUN13.1-1969. Appendix A. Section A2 The diatanoe from the last upatream diaturbance to the point of ample extration ahould be a minimum of five and preferably ten or more duct diameters downatream. Sampling from a vertioal run avoids atratification due to gnvity ecelling. Sampling as far downatream as possible avoide most tranuient variation in sirntream quality.
\end{abstract}

Comparison: See response to ANSI N13.1-1969, Section 4.2.1.2.

ANSI N13.1-1969. Appendix A. Section A3.1 Velocity and flow distribution should be known for the empling point, and particle and gascous composition should be representative.

Documentation: Maintenance Engineering Services Maintenance Procedure 7-GN-56, Rev 1

\section{GUIDANCE/DATA SHEET FOR 241-AY/AZ BACKUP EXHAUST STACK (296-A-27) FLOW MEASUREMENT}

Comparison: The partical and gaseous composition are assumed to be uniform since this is a vertical stack and the effluent should be well mixed when it reaches the sampling location (i.e., stack flow is turbulent). The stack flow distribution at the sampling location is uniform, however, this distribution is based on a very limited amount of data (see Figures D-1 and D-2). Use the following equation to convert from velocity pressure (inches water, gauge) to velocity (feet per minute).

$$
\text { Velocity }=4005 * \sqrt{\text { VelocityPressure }}
$$


Figure D-1. Stack Flow Distribution 296-A-27-A.

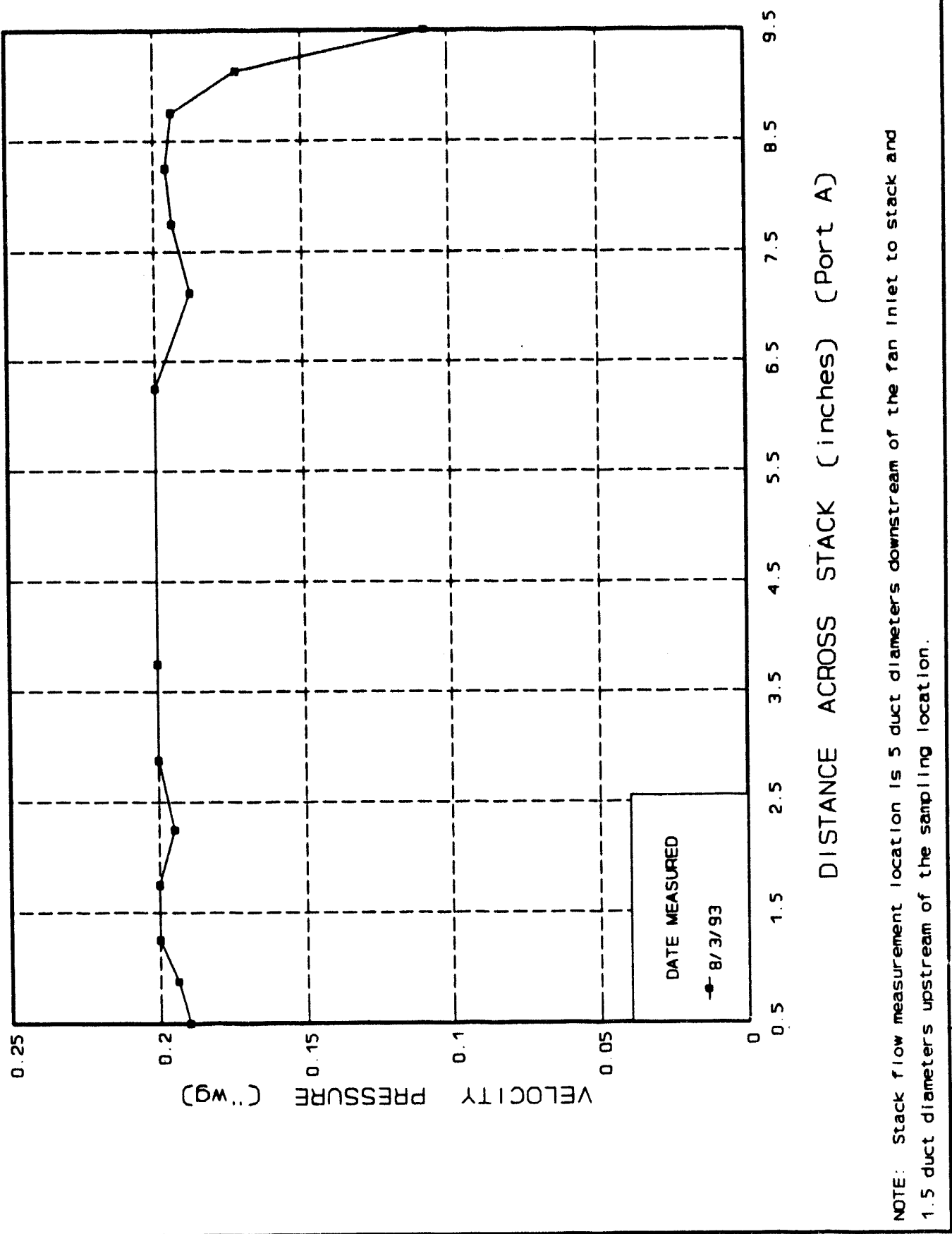


Figure D-2. Stack Flow Distribution 296-A-27-B.

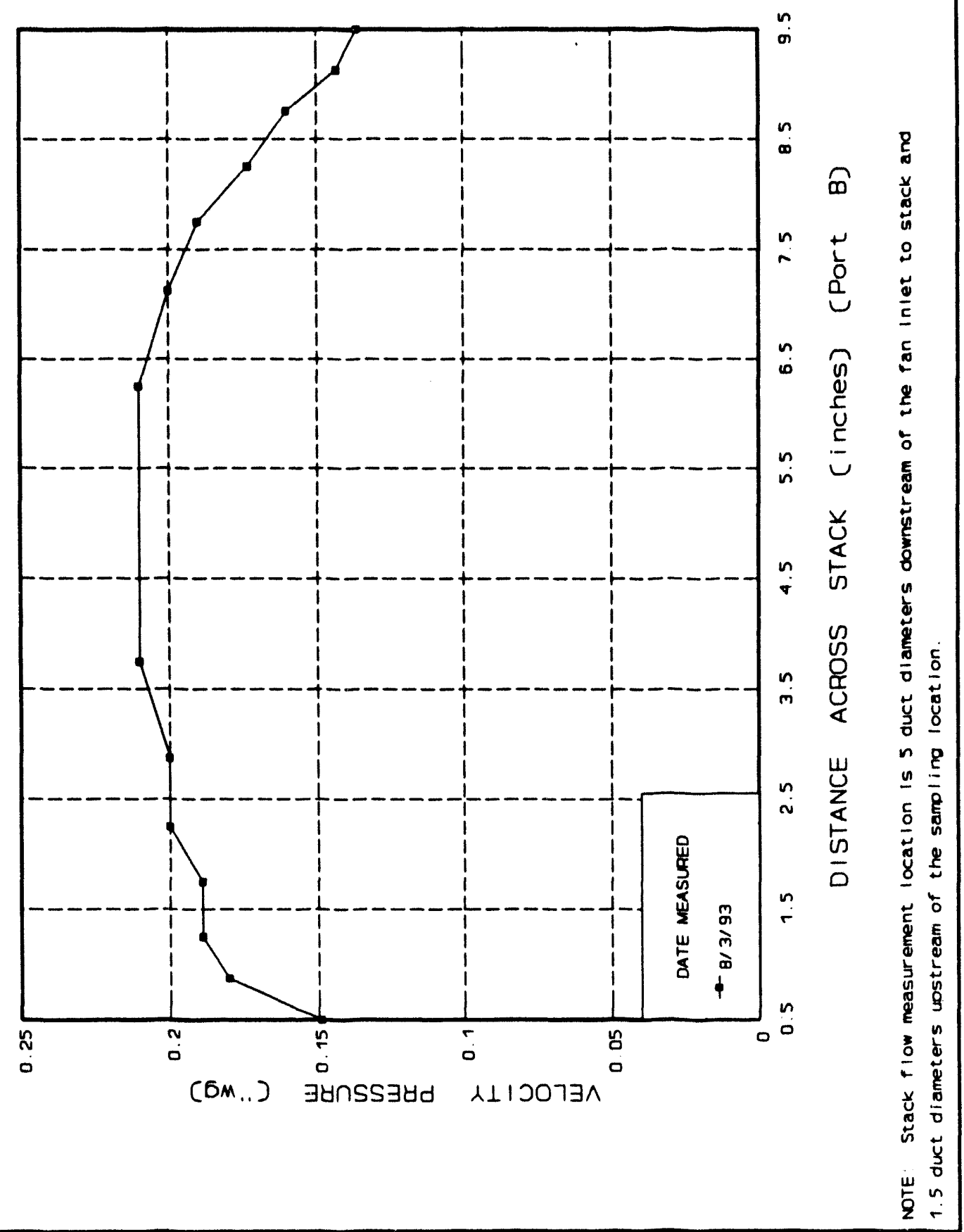


ANSI N13.1-1969. Appendix A. Section A3.2 A muttiple number of withdrawal points each representing approximulely equal areas based on the duct or stuck dimenaions in desirable.

Documentation: Drawing $\mathrm{H}-2-70358$

Comparison: The stack has an inside diameter of $25 \mathrm{~cm}$ (10 in.). A minimum of two sample points are required by ANSI Section A3.2. The stack contains two sample points on the sample probe. To be located at the midpoints of three equal areas in the stack, the nozzles should be located at the following distances from the center of the stack: 0 and $10.9 \mathrm{~cm}$ ( 0 and $4.3 \mathrm{in}$.). The nozzles are located at 0 and $10.8 \mathrm{~cm}$ ( 0 and 4.25 in.) from the center of the stack, and represent approximately equal areas.

ANSI N13.1-1969. Appendix A. Section A3.3 The velocity distribution acrose the duct or atack should be known in order to eatublinh isokinatic thow and representative sample points.

Comparison: (See response to ANSI N13.1 Section 4.2.2.3 and Appendix A Section A3.1.

ANSI N13.1-1969. Appendix A. Section A3.4 Sampling probe configuration is recommended by figures in this ANSI Standard, with minimum radius benda and preoisely tuperod probe end edgea.

Decumentation: Drawing H-2-70358

Comparison: The nozzles are 1.4 and $1.7 \mathrm{~cm}(0.54$ and $0.675 \mathrm{in.})$ OD with a side wall thickness of .22 and $2.3 \mathrm{~cm}(0.088$ and 0.91 in.) respectively [ID $=.92$ and $1.25 \mathrm{~cm}(0.364$ and $0.493 \mathrm{in}$.$) respectively]. The$ nozzle bends are specified as 3.2 and $4.76 \mathrm{~cm}$ (1.25 and $1.875 \mathrm{in}$. respectively.

Subpart H Section 61.93(b)(2)(iii) (sce Appendix N)

Subpart H Section 61.93(b)(2)(iv) (nee Appendix N)

Subpart H Section 61.93(b)(3) (coe Appendix N)

Subpart H Section 61.93(b)(4)(i) (see Appendix N)

Subpart H Section 61.93(b)(4)(ii) (sce Appendix N)

Subpart H. Section 61.93(b)(5) (sce Appendix N) 
This page intentionally left blank. 
WHC-EP-0784

APPENDIX E

40 CFR 61.93, SUBPART H COMPARISON FOR 296-A-29

E-1 
This page intentionally left blank. 


\section{POINT-BY-POINT NESHAP COMPLIANCE COMPARISON FOR THE 241-AN TANK FARM EXHAUSTER STACK NUMBER 296-A-29}

\section{Subpart H Section 61.93 (a) (coe Appendix N)}

Sybpart H Section 61.93 (b) Radionuclide umisuion rates from point sources (atacks or vents) shall be measured in acoordance with the following requirements or procedurea for which EPA has granted prior approval:

Subpart H Section 61.93 (b)(1) Emuent flow ruse measurements shall be made uaing the following methods:

Subpart H Section 61.93 (b)(1)(i) Reference Method 2 of Appendix A to Part 60 shall be used to determine velocities and volumetric flow ratos for atacks and large vents.

\section{Documentation: Drawing H-2-71936}

Comparison: $\quad$ Method 2 is for stacks larger than $30 \mathrm{~cm}$ (12 in.). This stack is smaller than the $30 \mathrm{~cm}$ (12 in.) applicability criteria; it is only $25 \mathrm{~cm}$ (10 in.). Method $2 \mathrm{C}$ is applicable for small stacks. See discussion under Method $2 \mathrm{C}$ below.

Subpart H Section 61.93 (b)(1)(ii) Reference Method $2 A$ of Appendix A to Part 60 shall be used to determine velocities and volumetric flow rates through pipes and amall ducts.

Documentation: Not applicable.

Comparison: Method $2 \mathrm{~A}$ is not applicable for stacks. If it is applicable for pipes and ducts where the entire effluent is run through a measuring device, this method may be applicable to the sampling systems themselves.

40 CFR 60. Appendix A. Method 2C Determination of Stack Gas Velocity and Volumetric Flow Rate in Small Stacks or Ducts: This method allows for the following:

1. The colection of the meanrement site according to Method 1A in Appendix A of 40 CFR 60

2. The election of the number of traveree point mescurements according to Figure 1-2,

"Minimum number of traverse points for velocities (nonparticulate) traverses," in Method 1 in Appendix A of 40 CFR 60

3. The location of the individual traveree measurement points according to Table 1-2, "Location of Traverse Points in Circular Stacks" of Method 1 of Appendix A of 40 CFR 60.

4. Apparatus

5. Procedure. 
Documentation: Job Control System Work Packages listed under "Subpart H Section 61.93 (b) (1) (iii)"

\section{GUIDANCE, 241-AN PRIMARY EXHAUST STACK (296-A-29) FLOW MEASUREMENT}

Facilities Maintenance Support Services Preventive Maintenance Procedure 7-GN-56, Rev 2

Drawing H-2-71936

Comparison: See the discussion below under "Method 1A, Section 2.1.1: PM Measurement" for selection of the measurement site and requirements. There are two perpendicular ports where this measurement site is located. This site is $5.7 \mathrm{~cm}(2.25$ in.) below the longest nozzle opening of the sample probe. This location is $67.5 \mathrm{in}$. (6.8 duct diameters) below the top of the stack and $163 \mathrm{~cm}$ (64 in.) (6.4 duct diameters) above the fan discharge into the stack. Figure 1-2 of Method 1 in Appendix A of 40 CFR 60 specifies 12 measurements if the flow disturbances upstream of the site is greater than 6 duct diameters. Measurements are taken on each of 16 annular traverse points located according to Table 1-2, "Location of Traverse Points in Circular Stacks" of Method 1, of Appendix A of 40 CFR 60 . This is performed in each of the two perpendicular flow measurement ports.

A standard pitot tube is used as specified. However, the procedure is not duplicated. A new procedure is under development that will duplicate the regulatory procedure.

Subpart H Section 61.93 (b)(1)(iii) The frequency of flow rate measurements shall depend upon the variability of the effluent flow rate. For variable flow rates, continuous or frequent flow rates measurements shall be made. For relatively conatant flow rates only periodic measurements are necessary.

Documentation: The following flows were obtained from this facility. Note, where available the Job Control System. Work Package number and date the measurement was taken is given:

\section{DATE ELOW $\left(\mathrm{ft}^{3} / \mathrm{min}\right)$ WP\#}

$\begin{array}{lll}01 / 31 / 91 & 786 & \text { NONE } \\ 04 / 03 / 91 & 816 & \text { NONE } \\ 07 / 11 / 91 & 666 & \text { NONE } \\ 10 / 20 / 92 & 747 & 2 \text { E-92-01245 } \\ 03 / 05 / 93 & 761 & 2 E-93-00137 \\ 05 / 18 / 93 & 780 & 2 E-93-00571\end{array}$


$01 / 05 / 94 \quad 2 \mathrm{E}-93-1141$

AVERAGE

769

VARIABILITY

$-13 \% /+8 \%$

$\begin{array}{lc}\text { STANDARD DEVIATION } & 54 \\ \text { 95\% CONFIDENT INTERVAL } & 132 \\ \text { RANGE } & 637 \text { to } 901 .\end{array}$

Comparison: Although the regulations do not specifically define variable versus constants flow rate, a flow rate with a variability of less than \pm 20 percent has been defined at the Hanford Site as being continuous. This criteria is specified in SD-WM-CR-016. The flow rates given above are therefore, constant. The schedule for taking these flows is quarterly. Although the quarterly schedule is not always met, the requirement at the Hanford Site is to take flow rates at least annually when the exhauster is running. This exhauster always runs.

Subpart H Section 61.93 (b)(2) Redionuclides ahall be directly monitored or extracted, collocted and measured using the following methods:

Subpart H Section 61.93 (b)(2)(i) Reference Method 1 of Appendix A Part 60 shall be used to seloct monitoring or sampling sites.

40 CER 60. Appendix A. Method 1 Sample and Velocity Traverees for Stationary Sources.

40 CFR 60. Appendix A. Method 1. Section 1.2: Applicability This method is applicable to flowing gas atreams in ducts, stacks, and flues. This method cannot be used when: (1) flow is cyclonic or awirling (cee Section 2.4); (2) a stack is smaller than about $0.30 \mathrm{~m}$ (12 in.) in diameter, or 0.071 $\mathrm{m}^{2}$ (113 in. $\left.{ }^{2}\right)$ crose-sectional area; or (3) the measurement site is less than two stack or duct diameters downstream or less than a half diameter upatream from a flow disturbance.

Documentation: Drawing H-2-71936

Comparison: This stack is smaller than the $30-\mathrm{cm}(12-\mathrm{in}$.) applicability criteria; it is only $25 \mathrm{~cm}(10 \mathrm{in}$.$) . See Method 1 \mathrm{~A}$ below.

40 CER 60. Appendix A. Method 1. Section 2.1: Selection of Measurement Site Sampling or velocity mearurement is performed at a site located at least 8 stack or duct diameters downstream and 2 diameter upatream from any diaturbances auch as a bend, expansion, or contraction in the stack, or from a visible flame. If necesary, an alternative location may be selected, at a position at least 2 stack or duct diameters downetream and a half diameter upstreare from any flow disturbance.

Not applicable. This stack is smaller than the 30-cm (12-in.) applicability criteria; it is only $25 \mathrm{~cm}(10 \mathrm{in}$.). 
40 CER 60. Appendix A. Method 1A Sample and Velocity Traverees for Stationary Sources with Small Stacks or Ducts This method is applicable to atacks or ducts lese than about 0.30 $m$ (12 in.) in diamoter, or $0.071 \mathrm{~m}^{2}\left(113\right.$ in. $\left.^{2}\right)$ crowe-wectional area, but equal to or greater than about $0.10 \mathrm{~m}\left(4 \mathrm{in}\right.$.) in diameter or $0.00812 \mathrm{~m}^{2}\left(12.57 \mathrm{in}^{2}\right)$ in crose-ectional area.

\section{CFR 60. Appendix A. Method 1A. Section 2.1.1: PM Measurement} Method $1 \mathrm{~A}$ calls for the sampling sites to be preforably located at least 8 equivalent stack or duct diametere downetream and 10 equivalent diameters upatream from any flow disturbances. The velocity meanurement location is recommended to be at a site located 8 equivalent stack or duct diameters downtream of the sampling site. This method further atipulates that if auch locations are not available, then the campling aite should be located at least 2 equivalent stack or duct diameters downetream and $21 / 2$ rack diameters upetream from any flow disturbances. The velocity measurement device should then be located 2 equivalent stack diameters downstream from the sampling site.

Documentation: Job Control System Work Packages listed under "Subpart H Section 61.93 (b) (1) (iii)"

\section{GUIDANCE, 241-AN PRIMARY EXHAUST STACK (296-A-29) FLOW MEASUREMENT}

Facilities Maintenance Support Services Preventive Maintenance Procedure 7-GN-56, Rev 2

\section{Drawings H-2-71936}

Comparison: The opening of the longest sample nozzle is $165.7 \mathrm{~cm}$ (65.25 in.) below the top of the stack and $168.3 \mathrm{~cm}$ (66.25 in.) above the fan discharge into the stack. The flow measurement ports are $5.7 \mathrm{~cm}(2.25 \mathrm{in}$.) below the opening of the longest sample nozzle.

Flow measurements are accomplished via Facilities Maintenance Support Services Preventive Maintenance Procedure 7-GN-56, Rev 2. There are two perpendicular ports chosen for the measurement at this same location.

Measurements are taken on each of 16 annular traverse points located according to Table 1-2, "Location of Traverse Points in Circular Stacks" of Method 1, of Appendix A to this same regulation. This is performed in each of the two perpendicular flow measurement ports.

Subpart H Section 61.93 (b) (2) (ii) The effluent stream shall be directly monitored continuously with an in-line detector or representative anmples of the effluent stream shall be withdrawn continuously from the sampling site following the guidance presented in ANSI N13.1-1969 "Guide to Sampling Airborne Radioactive Materials in Nuclear Facilities" (including the guidance presented in Appendix A of ANSIN13.1). 
ANSIN13,1-1969, Guide to Sampling Airborne Radioactive Materials in Nuclear Facilitien The guidance of this atandard aturt in Section 4. Principles. Section 4.1 is General, Soction 4.2 is Representative Samples, Section 4.2.1 is Samples Representative According to Spacial Location, Section 4.2.1.1 is Sampling in a Zone Occupies by Workers. The firat section in this ANSI standand applicable to the comparieon of this document is 4.2.1.2.

ANSIN13.1-1969. Section 4.2.1.2 Sampling point should be a minimum of 5 diameters (or 5 times the major dimencios for rectanguler ducts) downstream from abrupt changes in flow direction or prominent tranditions.

Not applicable. 40 CFR 61.93 (b)(2)(i) specifies the site location. See comparison under "Method 1A, Section 2.1.1: Selection of Measurement Site."

ANSI N13.1-1969. Section 4.2.2 Samples abould be representative with respect to physical and chemical composition of airutream.

Documentation: WHC-SD-WM-EMP-031, Rev 0

Comparison: No particle size studies have been performed at this facility, although a particle loss determination has been informally (at this time) accomplished. Information given in WHC-SD-WM-EMP-031, Rev 0 suggests that the sample should consist mainly of ${ }^{137} \mathrm{Cs}$, and ${ }^{241} \mathrm{Am}$. These radionuclides are particulate in nature and are not volatile.

ANSI N13.1-1969. Section 4.3 Sample Programming Many factors enter into the design of a campling program. The sampling program includes the frequency, duration, and volume rate of ampling. In moat cases the relection of these three elements in programming will be a compromise between idea values and those which provide eafety and yet are technically, economically, and conveniently achieved.

ANSI N13.1-1969. Section 4.3.1 (nee Appendix N)

ANSI N13.1-1969. Section 4.3.2 (see Appendix N)

ANSI N13.1-1969. Section 4.3.3 (10e Appendix N)

ANSI N13.1-1969, Section 4.3.4 (sce Appendix N)

ANSI N13.1-1969, Section 4.3.5 (sce Appendix N)

ANSI N13.1-1969. Section 5. Methods

ANSI N13.1-1969. Section 5.1. General Two forms of airborne radioactive materials are particulate and gases; the particles can be solid or liquid, although particulates are generally considered to be small fragments of solids. . . . .

Documentation: WHC-SD-WM-EMP-031, Rev 0 
Comparison: Information given in WHC-SD-WM-EMP-031 suggest that the sample should consist mainly of ${ }^{137} \mathrm{Cs}$ and ${ }^{211} \mathrm{Am}$. These radionuclides are particulate in nature and not volatile.

\section{ANSI N13.1-1969. Section 5.2. Particles}

ANSI N13.1-1969, Section 5.2.1. Sample Delivery Principles concerning the removal of a representative portion of a contained etream, 4 from a large duct, have been presented in Section 4 . . . .

\section{ANSI N13.1-1969. Section 5.2.2. Particle Collectore without Sienificant Size} Differentiation Variow collectors are applicable to sampling airborne radiaactive materials. . . .

\section{ANSI N13.1-1969. Section 5.2.2.1 (coe Appendix N)}

\section{ANSI N13.1-1969. Section 5.2.2.1.7 (coe Appendix N)}

ANSI N13,1-1969. Section 5.3. Gases Airborne radioactive volatile materials and so-called "permanent gases auch as tritium are frequently important conteminants and their sampling and collection requires tochniques and methods differing from those used in particle eampling. .

\section{Documentation: WHC-SD-WM-EMP-031, Rev 0}

Comparison: The tanks at this facility contain radioactive iodine, however, the potential off-site dose from the radioactive iodine is less than 10 percent of the total potential off-site dose from this stack. Therefore, radioactive volatile sampling is not required.

\section{ANSI N13.1-1969. Section 6.0 (soe Appendix N)}

ANSI N13.1-1969. Appendix A. Section A1 Minimization of the length and bends of ample delivery lines will contribute to representative eampling.

\section{Documentation: H-2-71936}

Comparison: The sample line is approximately $1.5 \mathrm{~m}(5 \mathrm{ft})$ long from the record sampler probe connection outside the stack to the top of the sample cabinet. The tubing is $1.3-\mathrm{cm}$ (1/2 in.) O.D. X 0.065 WALL. There is a single bend radius that is designed to be as large as possible (5 in. minimum).

ANSI N13.1-1969. Appendix A. Section A2 The distance from the last upstream disturbance to the point of cample extraction should be a minimum of 5 and preferably ten or more duct diameters downstream. Sampling from a vertical run avoids atratification due to gravity settling. Sampling as far downstream as possible avoids most transient variation in airstream quality. 
Not applicable. 40 CFR 61.93 (b)(2)(i) specifies the site location. See comparison under "Method 1A, Section 2.1.1: Selection of Measurement Site."

ANSI N13.1-1969. Appendix A. Section A3.1 Velocity and flow diatribution whould be known for the ampling point, and particle and gasoous composition should be representative.

Documentation: Not applicable.

Comparison: Velocity measurements are accomplished by Facilities Maintenance Support Services Preventive Maintenance Procedure 7-GN-56, Rev 2, Airflow Capacity and Distribution Tests in conjunction with supplemental GUIDANCE, 241-AN PRIMARY EXHAUST STACK (296-A-29) FLOW MEASUREMENT. From the section above, "Subpart H Section 61.93 (b)(1)(iii)," the average flow rate was seen to be $21,491 \mathrm{~L} / \mathrm{min}\left(759 \mathrm{ft}^{3} / \mathrm{min}\right)$. For a $25-\mathrm{cm}(10$-in.) stack, this amounts to a velocity of $7 \mathrm{~m}(23 \mathrm{ft}) /$ second. According to Table A1 in the ANSI N13.1-1969 Standard laminar flows occur below .21 m $(0.68 \mathrm{ft}) /$ second. Above that turbulent flows exist. The velocity distribution is uniform, however, this distribution is based on a very limited amount of data (see Figures E-1 and E-2).

Use the following equation to convert from velocity pressure (inches water, gauge) to velocity (feet per minute).

Velocity $=4005 * \sqrt{\text { VelocityPressure }}$ 


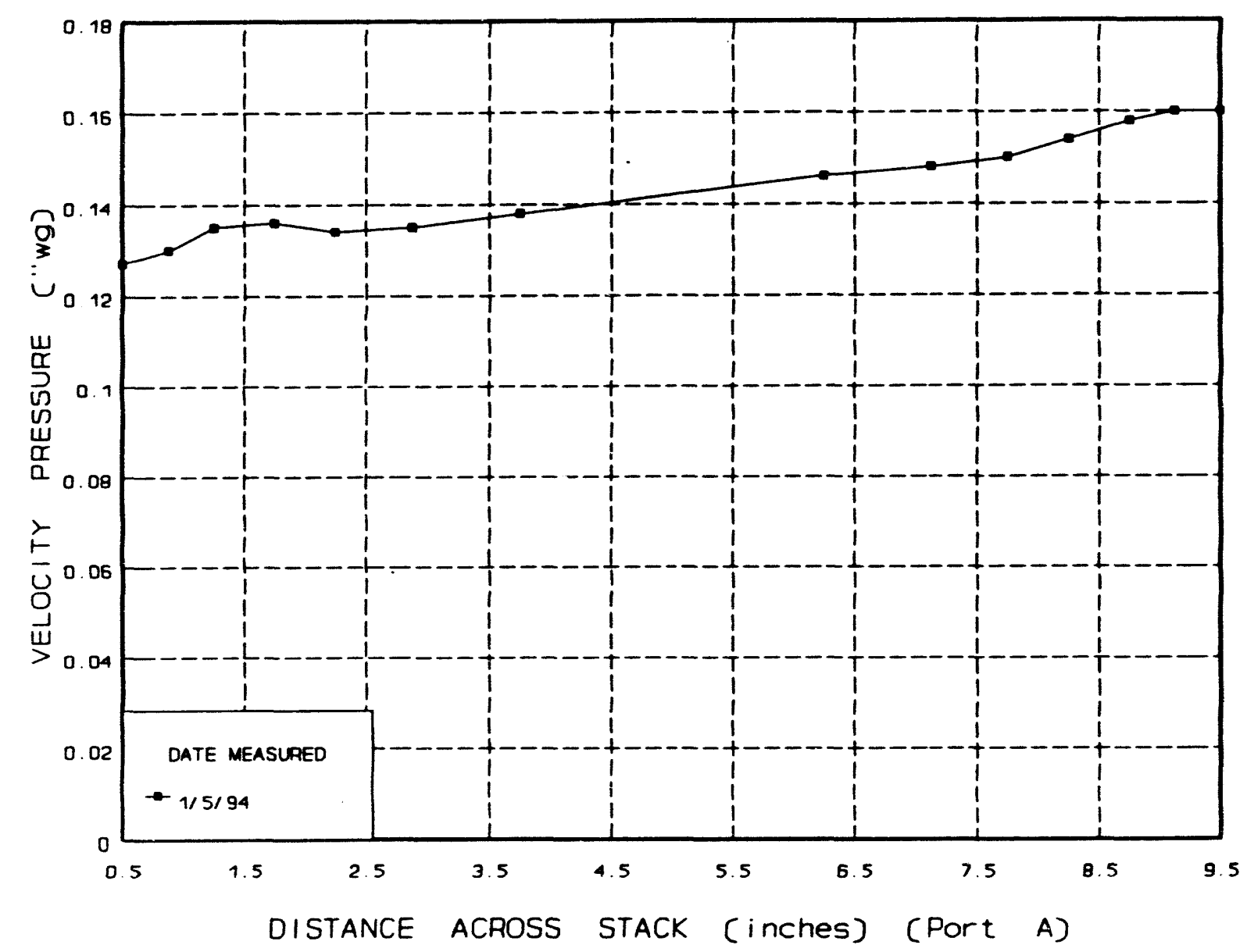

NOTE. Stack flow measurement location is 6.4 duct dlameters downstream of the fan inlet to stack and Just upstream of the samoling location. 
Pigure E-2. Stack Flow Distribution 296-A-29-B.

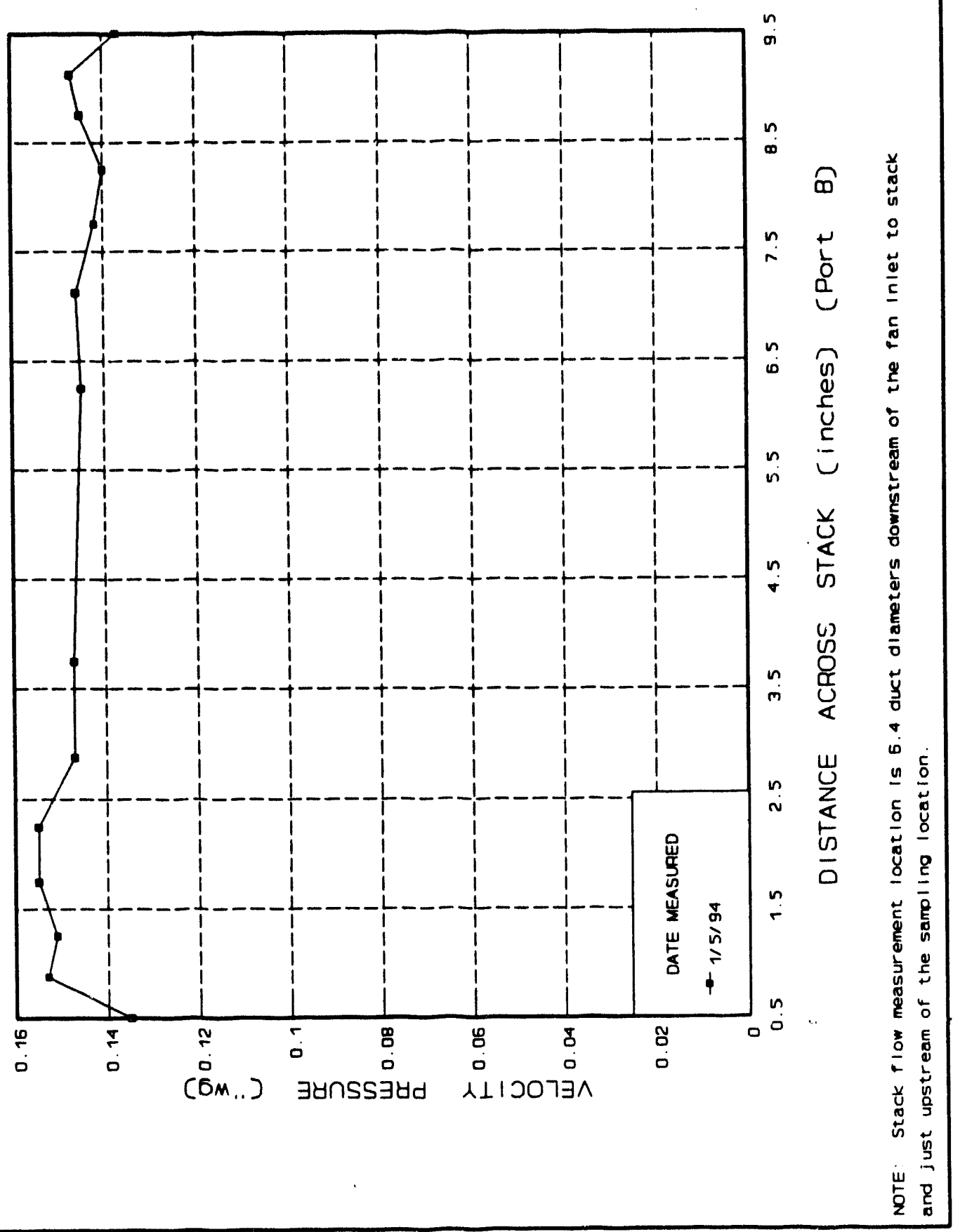


ANSIN13.1-1969. Appendix A. Section A3.2 A multiplo number of withdrawal points ouch representing approximately equal aren besed on the duct or atack dimensions is desirable.

Documentation: Drawing H-2-71955

Comparison: This drawing shows the probe with two nozzles. This is as recommended in this section of the ANSI N13.1-1969 Standard, Appendix A, paragraph A3.2.

ANSL N13.1-1969. Appendix A. Section A3.3 The velocity diatribution acroses the duct or atack chould bo known in order to eatablish ieokinetic flow and representative cample points.

Documentation: Job Control System Work Packages listed under "Subpart H Section 61.93 (b) (1) (iii)"

GUIDANCE, 241-AN PRIMARY EXHAUST STACK (296-A-29) FLOW MEASUREMENT

Facilities Maintenance Support Services Preventive Maintenance Procedure 7-GN-56, Rev 2

Drawing H-2-71936

Comparison: The designed isokinetic flow rate in the stack is $16,592 \mathrm{~L} / \mathrm{min}$ (586 $\left.\mathrm{ft}^{3} / \mathrm{min}\right)$, based on a sample flow of $62 \mathrm{~L} / \mathrm{min}\left(2.2 \mathrm{ft}^{3} / \mathrm{min}\right)$. Although, it is not reasonable to assume that the design flow is maintained. To determine the true or actual operating condition isokinetic flow rate sample data and instrumentation errors must be accounted for. From 1992 data, the actual sample flow at the sample nozzle openings (taking into account variability in the readings and instrumentation errors) is from 42.5 to $70.8 \mathrm{~L} / \mathrm{min}$ (1.5 to $\left.2.5 \mathrm{ft}^{3} / \mathrm{min}\right)$. From this, the actual or operating isokinetic flow rate in the stack is from 11,326 to $18,858 \mathrm{~L} / \mathrm{min}$ (400 to $666 \mathrm{ft}^{3} / \mathrm{min}$ ). Section Subpart H Section 61.93 (b)(1)(iii) above gives the actual flow rates measured in the stack. The average of this data is $21,491 \mathrm{~L} / \mathrm{min}\left(759 \mathrm{ft}^{3} / \mathrm{min}\right)$ with a 95 percent confidence that this flow rate will be between 17,753 to $25,257 \mathrm{~L} / \mathrm{min}(627$ to $\left.892 \mathrm{ft}^{3} / \mathrm{min}\right)$.

ANSL N13.1-1969. Appendix A. Section A3.4 Sampling probe configuration is recommended by figures in this ANSI Standard, with minimum radius bends and precieoly tapered probe end edges.

Documentation: Drawing H-2-71955 
Comparison: This drawing shows the probe with two nozzles as follows:

Nozzle A has an ID of $.92 \mathrm{~cm}(0.364$ in.), a bend radius of $3.2 \mathrm{~cm}$ (1.25 in.), and a length under the bend radius of $3.2 \mathrm{~cm}(1.25 \mathrm{in}$.$) .$

Nozzle B has an ID of $1.252 \mathrm{~cm}(0.4930 \mathrm{in}$.$) , a bend radius of$ $4.76 \mathrm{~cm}(1.875 \mathrm{in}$.$) , and a length under the bend radius of 4.76 \mathrm{~cm}$ (1.875 in.)

According to ANSI the bend radius and the vertical should both be 5 times the inside diameter. Five times the inside diameter of Nozzle $A$ is $4.6 \mathrm{~cm}(1.82 \mathrm{in}$.) and of Nozzle $B$ is $6.2 \mathrm{~cm}(2.46 \mathrm{in}$.). In addition, both nozzles are tapered to a knife edge. Lastly, the nozzles are approximately centered in equal annular areas.

\section{ANSI N13.1-1969, Appendix B. Particle Deposition in Sample Lines}

\section{Documentation: WHC-SD-WM-ES-291, Rev 1}

Comparison: The estimate made for this stack was made using an up-to-date computer software program. The program title is "DEPOSITION 2.0" and is references as Anand, N. K., McFarland, A.R., Wong, F.S, Kocmound C.J., DEPOSITION 2.0, NRC NuReg/GR-006, Serial \# 2145, March 8, 1993, Aerosol Technology Laboratory, Department of Mechanical Engineering, Texas A\&M University College Station, TX 77843.

Because particle sizes are not known, a spread of particle sizes were used (i.e, 10, 3.5 and 1 micron in size). The results are as follows:

Table C14. Stack Number 296-A-29 Sampling System Particle Penetration Percentage.

\begin{tabular}{|c|c|c|c|c|c|c|c|c|}
\hline & \multicolumn{8}{|c|}{ PARTICLE SIZE } \\
\hline Range & \multicolumn{2}{|c|}{$10 \mu \mathrm{m}$} & $\begin{array}{c}\text { PRE-HEPA } \\
\text { SPREAD } \\
(0.05 \text { to } 10 \mu \mathrm{m})\end{array}$ & \multicolumn{2}{c|}{$3.5 \mu \mathrm{m}$} & \multicolumn{2}{c|}{$1 \mu \mathrm{m}$} \\
\hline & Probe & Total & Probe & Total & Probe & Total & Probe & Total \\
\hline Minimum & 91.5 & 0.2 & 97.4 & 64.5 & 96.7 & 58.6 & 98.9 & 96.0 \\
\hline Average & 102.6 & 0.7 & 99.8 & 69.2 & 98.8 & 70.6 & 99.2 & 96.9 \\
\hline Maximum & 125.2 & 3.1 & 104.9 & 77.1 & 102.9 & 82.6 & 99.8 & 98.0 \\
\hline
\end{tabular}


The variables used in this program are as follows:

Stack diameter 10 in $=0.254 \mathrm{~m}$

Area $=\pi R^{2}=0.05067 \mathrm{~m}^{2}$

Stack Stream Velocity $(\mathrm{m} / \mathrm{s}): 5.84$ to 8.31

Average: 7.07

Probe Equivalent Radius $=0.3064$ in

Probe Equivalent Diameter $=0.6128 \mathrm{in} .=15.56555853 \mathrm{~mm}$

Designed Sample Flow Rate $=2.2 \mathrm{ft}^{3} / \mathrm{min}=62.29696 \mathrm{~L} / \mathrm{min}$

Sample Flow rate (L/min): 42.48 to 70.79

Average: 56.63

Line Length $=5 \mathrm{ft}=1.524 \mathrm{~m}$

Tube ID $=0.370 \mathrm{in} .=9.398 \mathrm{~mm}$

one $90^{\circ}$ bend

ANSI N13.1-1969. Appendix C. Errors Due to Anisokinetic Sampling Evaluated with the software discussed above under ANSI N13.1-1969, Appendix B, Particle Deposition in Sample Lines.

Subpart H Section 61.93 (b) (2) (iii) (coe Appendix N)

Subpart H Section 61.93(b)(2)(iv) (noe Appendix N)

Subpart H Section 61.93(b)(3) (coe Appendix N)

Subpart H Section 61.23(b)(4)(i) (sec Appendix N)

Subpart H Section 61.93(b)(4)(ii) (coe Appendix N)

Subpart H Section 61.93(b)(5) (soe Appendix N) 
APPENDIX F

40 CFR 61.93, SUBPART H COMPARISON FOR 296-B-28 
This page intentionally left blank. 


\section{POINT-BY-POINT NESHAP COMPLIANCE COMPARISON FOR THE 244-BX DOUBLE CONTAINED RECEIVER TANK EXHAUSTER STACK NUMBER 296-B-28}

\section{Subpart H Section 61.93 (9) (coe Appendix N)}

Subpart H Section 61.93 (b) Redionuclide emiesion rates from point sources (etecks or vents) shall be measured in accordance with the following requirements or procedures for which EPA has granted prior approval:

Subpart H Section 61.93 (b)(1) Effluent tow rate measurements shall be made using the following methods:

Subpart H Section 61.93 (b)(1)(i) Reference Method 2 of Appendix A to Part 60 shall be used to determine velocitiea and volumetric Dow nitea for atacks and large vents.

Documentation: Drawing H-2-73839

Comparison: Method 2 is for stacks larger than $30 \mathrm{~cm}$ (12 in.). This stack is smaller than the $30 \mathrm{~cm}$ (12 in.) applicability criteria; it is only $15 \mathrm{~cm}$ (6 in.). Method $2 \mathrm{C}$ is applicable for small stacks. See discussion under Method $2 \mathrm{C}$ below.

Subpart H Section 61.93 (b)(1)(ii) Reference Method 2A of Appendix A to Part 60 shall be used to determine velocitiea and volumetric flow rates through pipes and amall ducts.

Documentation: Not applicable.

Comparison: Method $2 \mathrm{~A}$ is not applicable for stacks. It is applicable for pipes and ducts where the entire effluent is run through a measuring device. This method may be applicable to the sampling systems themselves.

40 CFR 60. ADpendix A. Reference 2C Determination of Stack Gas Velocity and Volumetric Flow Rate in Small Stacks or Ducts This method allows for the following:

1. The election of the mearurement site according to Method 1A in Appendix A of 40 CFR 60

2. The celection of the number of traverse point measurements per Figure 1-2, "Minimum number of traverse points for velocities (nonparticulate) traverses," in Method 1 in Appendix $A$ of 40 CFR 60

3. The location of the individual traverse measurement points per Table 1-2, "Location of Traveree Points in Circular Stacks" of Method 1, of Appendix A of 40 CFR 60

4. Apparatus

5. Procedure. 
Documentation: Job Control System Work Packages listed under "Subpart $\mathbf{H}$ Section 61.93 (b) (1) (iii)"

\section{GUIDANCE/DATA SHEET FOR 244-BX DCRT EXHAUST STACK (296-B-28) FLOW MEASUREMENT}

Facilities Maintenance Support Services Preventive Maintenance Procedure 7-GN-56, Rev 2

Comparison: See the discussion below under "Method 1A, Section 2.1.1: PM Measurement" for selection of the measurement site and requirements. The measurement site is $1.8 \mathrm{~m} \mathrm{(6 \textrm {ft } )}(12$ duct diameters) below the top of the stack, $.76 \mathrm{~m}(2.5 \mathrm{ft})(5$ duct diameters) below the bottom of the record sampler probe nozzle opening and $.60 \mathrm{~m}(2 \mathrm{ft})(4$ duct diameters) above the fan discharge into the stack. Figure 1-2 of Method 1 in Appendix A of 40 CFR 60 specifies 16 measurements if the flow disturbances upstream of the site is less than 6 duct diameters. However, this figure is mainly for large stacks (although it is referenced for use with small stacks). In a stack that is $15 \mathrm{~cm}$ (6 in.) in diameter, an increasing number of measurement points is senseless. Logically, there comes a point when additional data points are no longer useful. Therefore it was decided that measurements would be taken on each of 8 annular traverse points located according to Table 1-2, "Location of Traverse Points in Circular Stacks" of Method 1, of Appendix A of 40 CFR 60. This is performed in each of the two perpendicular flow measurement ports.

A standard pitot tube is used as specified. However, the procedure is not duplicated. A new procedure is under development which will duplicate the regulatory procedure.

Subpart H Section 61.93 (b)(1)(iii) The frequency of flow rate measurements shall depend upon the variability of the effluent flow rate. For variable flow rates, continuous or frequent flow rates measurements shall be made. For relatively constant flow rates, only periodic measurements are necesury. 
Documentation: The following flows were obtained from this facility. Note, where available the Job Control System Work Package number and date the measurement was taken is given:

$\begin{array}{ccl}\text { DATE } & \text { ELOW }\left(\mathrm{ff}^{3} / \mathrm{min}\right) & \text { WP\# } \\ 02 / 06 / 91 & 262 & \text { NONE } \\ 05 / 30 / 91 & 243 & \text { NONE } \\ 08 / 12 / 91 & 220 & \text { NONE } \\ 05 / 04 / 93 & 233 & 2 \mathrm{E}-92-00903\end{array}$

AVERAGE $\quad 240$

VARIABILITY $-8 \% /+9 \%$

STANDARD DEVIATION 18

95\% CONFIDENCE INTERVAL 56

RANGE 183 to 296

Comparison: Although the regulations do not specifically define variable versus constants flow rate, a flow rate with a variability of less than \pm 20 percent has been defined at the Hanford Site as being continuous. This criteria is specified in SD-WM-CR-016. The flow rates given above are therefore constant. The schedule for taking these flows is quarterly. Although the quarterly schedule is not always met, the requirement at the Hanford Site is to take flow rates at least annually when the exhauster is running. This exhauster does not always run. Its purpose is to run when the temperature of the waste in the tank is above $60^{\circ} \mathrm{C}\left(140^{\circ} \mathrm{F}\right)$ and/or while waste is being transferred through this facility.

Subpart H Section 61.93 (b)(2) Radionuclides shall be directly monitored or extracted, collected and measured using the following methods:

Subpart H Section 61.93 (b)(2)(i) Reference Method 1 of Appendix A Part 60 shall be used to select monitoring or sampling sites.

40 CFR 60. Appendix A. Method 1 Sample and Velocity Traverses for Stationary Sources.

40 CER 60. Appendix A. Method 1. Section 1.2: Applicability This method is applicable to flowing gas streams in ducts, stacks, and flues. This method cannot be used when (1) flow is cyclonic or awirling (cee Section 2.4); (2) a stack is smaller than about $0.30 \mathrm{~m}$ (12 in.) in diameter, or 0.071 $\mathrm{m}^{2}$ (113 in. ${ }^{2}$ cross-sectional area; or (3) the measurement site is less than two stack or duct diameters downstream or less than a half diameter upstream from a flow disturbance.

Documentation: Drawing H-2-73839 
Comparison: This stack is smaller than the $30 \mathrm{~cm}$ (12 in.) applicability criteria; it is only $15 \mathrm{~cm}(6 \mathrm{in}$.$) . See Method 1 \mathrm{~A}$ below.

\section{CFR 60. Appendix A. Method 1. Section 2.1: Selection of Measurement Site}

Sampling or velocity meanurement is performed at a site locatod at least oight atack or duct diameters downetream and two diameters upatream from any disturbances auch as a bend, expansion, or contraction in the atack, or from a visible flame. If necesary, an alternative location may be selected, at a position at least two atack or duct diameters downstream and a half diameter upatream from any flow disturbance.

Comparison: Not applicable. This stack is smaller than the 12 in. applicability criteria; it is only 6 in. $(15.24 \mathrm{~cm})$.

40 CFR 60, Appendix A. Method 1A Sample and Volocity Traverees for Stationary Sources with Small Stacks or Ducts This method is applicable to atacks or ducts leas than about $0.30 \mathrm{~m}$ (12 in.) in diameter, or $0.071 \mathrm{~m}^{2}$ (113 in. $\left.{ }^{2}\right)$ cross-eectional area, but equal to or greater than about $0.10 \mathrm{~m}$ (4 in.) in diameter or $0.00812 \mathrm{~m}^{2}\left(12.57 \mathrm{in}^{2}\right)$ in cross-ecetional area.

\section{CER 60. Appendix A. Method 1A. Section 2.1.1: PM Measurement} Method 1A calls for the sampling sites to be preferably located at least 8 equivalent stack or duct diameters downatream and 10 equivalent diameters upstream from any flow disturbances. The velocity measurement location is recommended to be at a site located 8 equivalent stack or duct diameters downstream of the sampling site. This method further stipulates that if such locations are not available, then the ampling cite should be located at least 2 equivalent stack or duct diameters downstream and $21 / 2$ ack diameters upatream from any flow diaturbances. The velocity measurement device should then be located 2 equivalent stack diameters downstream from the sampling site.

Documentation: Drawing H-2-73839

\section{GUIDANCE/DATA SHEET FOR 244-BX DCRT EXHAUST STACK (296-B-28) FLOW MEASUREMENT}

Facilities Maintenance Support Services Preventive Maintenance Procedure 7-GN-56, Rev 2

Comparison: This stack is smaller than the $30 \mathrm{~cm}$ (12 in.) applicability criteria; it is only $15 \mathrm{~cm}(6 \mathrm{in}$.$) .$

This stack is $15 \mathrm{~cm} \mathrm{(6} \mathrm{in.)} \mathrm{in} \mathrm{diameter.} \mathrm{The} \mathrm{sample} \mathrm{probe}$ location is located $1.5 \mathrm{~m}(5 \mathrm{ft})$ above the fan discharge into the stack. The closest flow disturbances are the CAM sample probe, located 4 duct diameters downstream, and the fan inlet to the stack, located 10 duct diameters upstream of the sample probe.

Flow measurements are accomplished via Facilities Maintenance Support Services Preventive Maintenance Procedure 7-GN-56, Rev 2. There are two perpendicular ports chosen for the measurement. These ports are one duct 
diameter below the center line of the record sample probe (the record sample probe extends 15 vertical $\mathrm{cm}(6$ in.) down from its centerline) and 9 duct diameters above the fan discharge into the stack. Although this location is not downstream of the sample probe, it is considered to be a conservative location for measurement purposes for two reasons:

1. There are two sample probes on this stack. One is for a continuous monitor and one is for the record sampler. Each probe draws a sample at a rate of approximately $57 \mathrm{~L} / \mathrm{min}\left(2 \mathrm{ft}^{3} / \mathrm{min}\right)$ of air flow from the stack to total $113 \mathrm{~L} / \mathrm{min}\left(4 \mathrm{ft}^{3} / \mathrm{min}\right)$. This sample flow taken from the average stack flow given above of $6,795 \mathrm{~L} / \mathrm{min}$ (240 $\left.\mathrm{ft}^{3} / \mathrm{min}\right)$, will result in $6,654 \mathrm{~L} / \mathrm{min}\left(235 \mathrm{ft}^{3} / \mathrm{min}\right)$ downstream of all three sample probes. Although $113 \mathrm{~L} / \mathrm{min}\left(4 \mathrm{ft}^{3} / \mathrm{min}\right)$ only represents 2 percent of the average stack flow, a more conservative representation of the actual totalized flow can be gained from the measurement occurring below the sample probes. Totalized flow is necessary for total emission calculations.

2. Since the probes are removing air from the stack stream, the location of the flow measurement below the sample probes give a truer representation of the flow rate for the first sample probe (the record sampler). This allows for a truer representation of the isokinetic flow conditions, used to determine the efficiency of the system.

Measurements are taken on each of 8 annular traverse points located according to Table 1-2, "Location of Traverse Points in Circular Stacks" of Method 1, of Appendix A to this same regulation. This is performed in each of the two perpendicular flow measurement ports.

Subpart H Section 61.93 (b) (2) (ii) The effluent stream shall be directly monitored continuously with an in-line detector or representative samples of the effluent stream shall be withdrawn continuously from the sampling site following the guidance presented in ANSI N13.1-1969 "Guide to Sampling Airbome Radioactive Materials in Nuclear Facilities" (including the guidance presented in Appendix A of ANSIN13.1).

ANSI N13.1-1969. Guide to Sampling Airborne Radioactive Materials in Nuclear Facilities The guidance for this standard begins in Section 4.0 Principles. Section 4.1 is General, Section 4.2 is Representative Samples, Section 4.2.1 is Samples Representative According to Spacial Location, Section 4.2.1.1 is Sampling in a Zone Occupies by Workers. The first section in this ANSI standard applicable to the comparison of this document is 4.2.1.2. 
ANSI N13.1-1969. Section 4.2.1.2 Sampling point thould be a minimum of 5 diameters (or 5 times the major dimension for rectangular ducts) downatream from abrupt changes in flow direction or prominent transitions.

Not applicable. 40 CFR 61.93 (b)(2)(i) specifies the site location. See comparison under "Method 1A, Section 2.1.1: Selection of Measurement Site."

ANSI N13,1-1969. Section 4.2.2 Samples should be representative with respect to physical and chemical composition of airatream.

Documentation: WHC-SD-WM-EMP-031, Rev 0

Comparison: No particle size studies have been performed at this facility, although a particle loss determination has been informally (at this time) accomplished. Information provided in WHC-SD-WM-EMP-031, Rev 0 suggest that the sample should consist mainly of ${ }^{137} \mathrm{Cs}$, ${ }^{239220} \mathrm{Pu}$, and ${ }^{211} \mathrm{Am}$. These radionuclides are particulate in nature and are not volatile.

ANSI N13.1-1969. Section 4.3. Sample Programming Many factors enter into the design of a campling program. The campling program includes the frequency, duration, and volume rate of sampling. In most cases the selection of these three elementa in programming will be a compromise between idea values and those which provide anfety and yet are technically, economically, and conveniently achieved.

\section{ANSI N13.1-1969. Section 4.3.1 (see Appendix N)}

ANSI N13.1-1969. Section 4.3.2 (see Appendix N)

ANSI N13.1-1969. Section 4.3.3 (see Appendix N)

ANSI N13.1-1969. Section 4.3.4 (see Appendix N)

ANSI N13.1-1969. Section 4.3.5 (see Appendix N)

\section{ANSI N13,1-1969. Section 5, Methods}

ANSI N13,1-1969. Section 5.1. General Two forms of airborne radioactive materials are particulate and gases; the particles can be solid or liquid, although particulates are generally considered to be very small fragments pf solids. ....

\section{Documentation: WHC-SD-WM-EMP-031, Rev 0}

Comparison: Information shown in WHC-SD-WM-EMP-031 suggests th $t$ the sample should consist mainly of ${ }^{137} \mathrm{Cs}$, ${ }^{239240} \mathrm{Pu}$, and ${ }^{211} \mathrm{Am}$. These radionuclides are particulate in nature and are not volatile. 


\title{
ANSLN13.1-1969, Section 5.2. Particles
}

ANSI N13.1-1969. Section 5.2.1. Sample Delivery Principles concerning the removal of a representative portion of a contained atream, as from a large duct, have been presented in Section 4. . . .

\section{ANSI N13.1-1969. Section 5.2.2. Particle Collectors without Significant Size}

Differentiation Various collectors are applicable to sampling airborne radioactive materials. ... .

\section{ANSIN13.1-1969. Section 5.2.2.1 (coe Appendix N)}

\section{ANSI N13.1-1969. Section 5.2.2.1.7 (20e Appendix N)}

\begin{abstract}
ANSI N13.1-1969. Section 5.3. Gases Airborne radioactive volatile materials and so-called "permanent gaces auch es tritium are frequently important contaminants and their sampling and collection requires tochniques and methods differing from those used in particle sampling. .
\end{abstract}

\section{Documentation: WHC-SD-WM-EMP-031, Rev 0}

Comparison: No volatile radionuclides are present at this facility

\section{ANSLN13.1-1969. Section 6.0 (coe Appendix N)}

ANSI N13.1-1969. Appendix A. Section A1 Minimization of the length and bends of sample delivery lines will contribute to representative sampling.

\section{Documentation: H-2-73809}

Comparison: The sample line is approximately $1.5 \mathrm{~m}(5 \mathrm{ft})$ long. The tubing is $1.3 \mathrm{~cm}(1 / 2$-in.) O.D. X 0.035 WALL. There is one 90 degree bend.

\begin{abstract}
ANSI N13.1-1969. Appendix A. Section A2 The distance from the last upstream disturbance to the point of sample extraction should be a minimum of 5 and preferably 10 or more duct diameters downstream. Sampling from a vertical run avoids atratification due to gravity settling. Sampling as far downstream as possible avoids most transient variation in airstream quality.
\end{abstract}

Not applicable. 40 CFR 61.93 (b)(2)(i) specifies the site.location. See.comparison under "Method 1A, Section 2.1.1: Selection of Measurement Site."

ANSI N13.1-1969. Appendix A. Section A3.1 Velocity and flow distribution should be known for the sampling point, and particle and gaseous composition shouid be representative.

Documentation: Not applicable. 
Comparison: Velocity measurements are accomplished by Facilities Maintenance Support Services Preventive Maintenance Procedure 7-GN-56, Rev 2, Airflow Capacity and Distribution Tests in conjunction with supplemental

\section{GUIDANCE/DATA SHEET FOR 244-BX DCRT EXHAUST} STACK (296-B-28) FLOW MEASUREMENT. From the section above, "Subpart H Section 61.93 (b)(1)(iii)," the average flow rate was seen to be $6,796 \mathrm{~L} / \mathrm{min}\left(240 \mathrm{ft}^{3} / \mathrm{min}\right)$. For a 6 in. stack, this amounts to a velocity of $6.1 \mathrm{~m}(20 \mathrm{ft}) / \mathrm{sec}$. Table A1 in the ANSI N13.1-1969 Standard laminar flows occur below $0.68 \mathrm{ft} /$ second. Above that turbulent flows exist. Again according to ANSI N13.1-1969 Section A3.3.2 "as the flow becomes more turbulent, the velocity becomes more nearly uniform across the duct." The velocity distribution at the flow measurement location is relatively uniform (see Figure F-1), but is based on a very limited amount of data. Note that the flow measurement location is six duct diameters upstream from the sampling location. Since there are no flow disturbances between the flow measurement location and the sampling location, the distribution at the sampling location should be more uniform. Use the following equation to convert from velocity pressure (inches water, gauge) to velocity (feet per minute).

$$
\text { Velocity }=4005 * \sqrt{\text { VelocityPressure }}
$$


Figure F-1. Stack Flow Distribution 296-B-28-A.

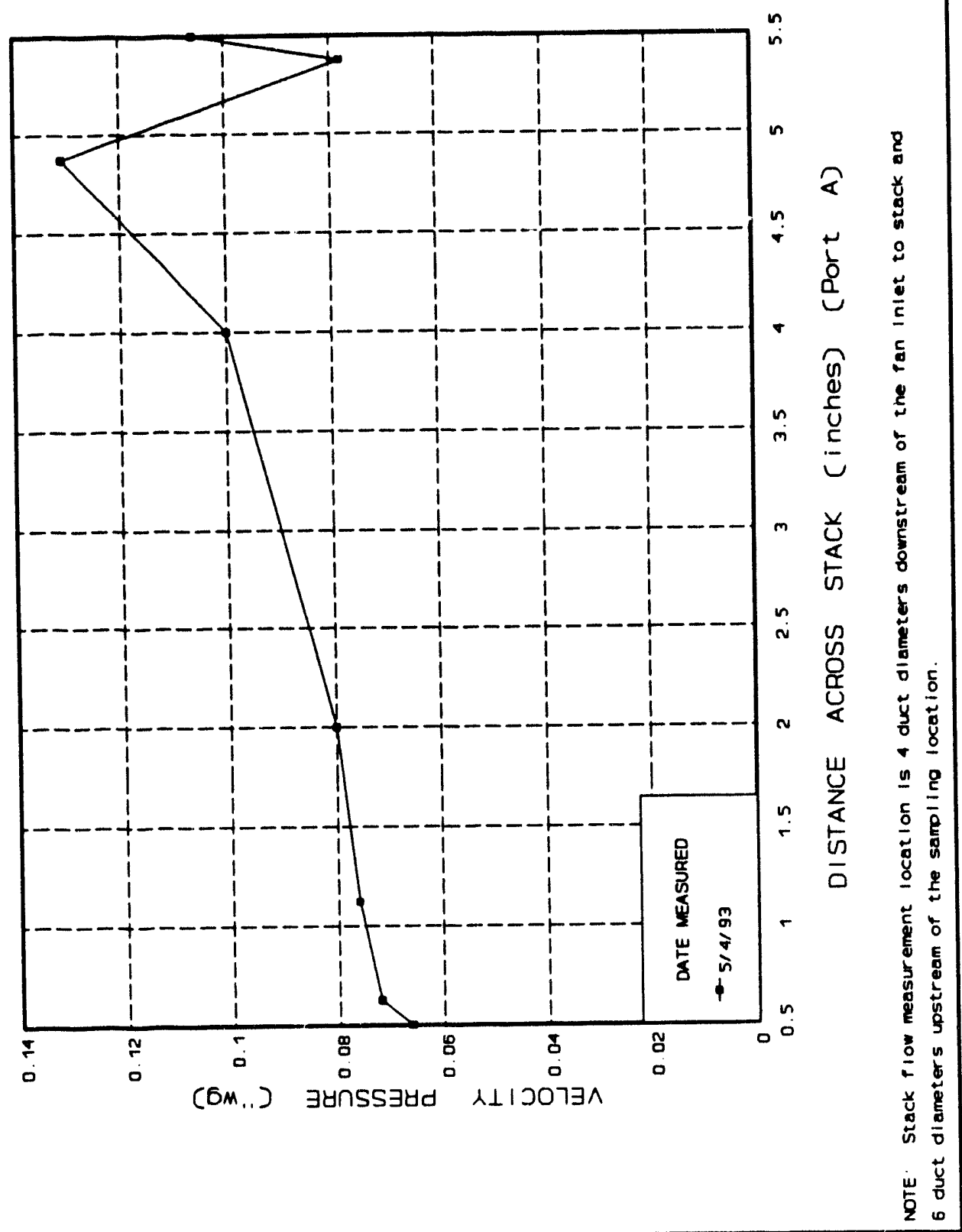


ANSI N13.1-1969. Appendix A. Section A3,2 A multiple number of withdrawal points each representing approximatoly equal areas baced on the duct or stack dimonsions is desirable.

Documentation: Drawing H-2-73809

Comparison: This drawing shows the probe with one nozzle. This is as recommended in this section of the ANSI N13.1-1969 Standard for this size stack (6 in.).

ANSI N13.1-1969. Appendix A. Section A3.3 The velocity distribution acroes the duct or stack ahould be known in order to establish isokinetic flow and representative sample points.

Documentation: Facilities Maintenance Support Services Preventive Maintenance Procedure 7-GN-56, Rev 2

\section{GUIDANCE/DATA SHEET FOR 244-BX DCRT EXHAUST STACK (296-B-28) FLOW MEASUREMENT}

Comparison: The velocity distribution is not known. However, uniform distribution may be assumed (see discussion under

"ANSI N13.1-1969, Appendix A, Section A3.1" above).

The designed isokinetic flow rate in the stack is $7,673 \mathrm{~L} / \mathrm{min}$ (271 $\left.\mathrm{ft}^{3} / \mathrm{min}\right)$, based on a sample flow of $62 \mathrm{~L} / \mathrm{min}\left(2.2 \mathrm{ft}^{3} / \mathrm{min}\right)$. Although, it is not reasonable to assume that the design flow is maintained. To determine the true or actual operating condition isokinetic flow rate sample data and instrumentation errors must be accounted for. From 1992 data, it can be shown that the actual sample flow at the sample nozzle openings (taking into account variability in the readings and instrumentation errors) is from 6.7 to $59.5 \mathrm{~L} / \mathrm{min}\left(0.9\right.$ to $\left.2.1 \mathrm{ft}^{3} / \mathrm{min}\right)$. From this, the actual or operating isokinetic flow rate in the stack is from 3,143 to $1,334 \mathrm{~L} / \mathrm{min}$ (111 to $259 \mathrm{ft}^{3} / \mathrm{min}$ ). Section Subpart H Section 61.93 (b)(1)(iii) above gives the actual flow rates measured in the stack. The average of this data is $6,796 \mathrm{~L} / \mathrm{min}\left(240 \mathrm{ft}^{3} / \mathrm{min}\right)$ with a 95 percent confidence that this flow rate will be between 5,182 to $8,381 \mathrm{~L} / \mathrm{min}$ (183 to $296 \mathrm{ft}^{3} / \mathrm{min}$ ). ANSI N13.1-1969. Appendix A. Section A3.4 Sampling probe configuration is recommended
by figures in this ANSI Standard, with minimum radius bends and preciecly tapered probe end edges.

Documentation: Drawing H-2-73809

Comparison: This drawing shows the probe as a 1.3- $\mathrm{cm}$ (1/2-in.) SCHD 80 pipe with a 8-cm (3-in.), 90 degree radius bend and a 3 in. vertical length under that. The inside diameter of this probe is $1.387 \mathrm{~cm}(0.546 \mathrm{in}$.) According to ANSI the bend radius, as well as the vertical should 
both be 5 times the inside diameter. Five times the inside diameter of this probe is $6.93 \mathrm{~cm}(2.73 \mathrm{in}$.$) . In addition the nozzle is tapered$ to a knife edge.

\section{ANST N13.1-1969. Appendix B. Particle Deposition in Sample Lines}

\section{Documentation: WHC-SD-WM-ES-291, Rev 1}

Comparison: The estimate made for this stack was made using an up-to-date computer software program. The program title is

"DEPOSITION 2.0" and is reference as Anand, N. K., McFarland, A.R., Wong, F.S, Kocmound C.J., DEPOSITION 2.0, NRC NuReg/GR-006, Serial \# 2145, March 8, 1993, Aerosol Technology Laboratory, Department of Mechanical Engineering, Texas A\&M University College Station, TX 77843. This program also provides for anisokinetic sampling affects as discussed in ANSI N13.1-1969, Appendix C.

Because particle sizes are not know a spread of particle sizes were used i.e., 10, 3.5 and 1 micron in size. The results are as follows:

STACK NUMBER 296-B-28 SAMPLING SYSTEM PARTICLE PENETRATION PERCENTAGE

\begin{tabular}{|c|c|c|c|c|c|c|}
\hline & \multicolumn{6}{|c|}{ PARTICLE SIZE } \\
\hline Range & \multicolumn{2}{|c|}{$10 \mu \mathrm{m}$} & \multicolumn{2}{c|}{$3.5 \mu \mathrm{m}$} & \multicolumn{2}{c|}{$1 \mu \mathrm{m}$} \\
\hline & Probe & Total & Probe & Total & Probe & Total \\
\hline Minimum & 87.2 & 3.6 & 95.9 & 78.8 & 98.7 & 97.2 \\
\hline Average & 100.3 & 16.8 & 98.4 & 86.4 & 99.2 & 98.0 \\
\hline Maximum & 140.3 & 69.3 & 105.7 & 97.6 & 100.2 & 99.4 \\
\hline
\end{tabular}

The variables used to derive the values in this table are as follows:

Stack diameter 6 in. $=0.1524 \mathrm{~m}$

Area $=\pi R^{2}=0.01824 \mathrm{~m}^{2}$

Stack Stream Velocity $(\mathrm{m} / \mathrm{s}): 4.73$ to 7.66

Average: 6.21

Probe Equivalent Radius $=0.273$ in .

Probe Equivalent Diameter $=0.546 \mathrm{in} .=13.8684 \mathrm{~mm}$ 
Designed Sample Flow Rate $=2.2 \mathrm{ft} / \mathrm{min}=62.29696 \mathrm{~L} / \mathrm{min}$

Sample Flow rate $(\mathrm{L} / \mathrm{min}): 25.49$ to 59.47

Average: 42.48

Line Length $=5 \mathrm{ft}=1.524 \mathrm{~m}$

Tube ID $=0.43 \mathrm{in} .=10.922 \mathrm{~mm}$ one $90^{\circ}$ bend

ANSI N13.1-1969. Appendix C. Errors Due to Anisokinetic Sampling Evaluated with the coftware diccusced above under ANSI N13.1-1969, Appendix B, Particle Doposition in Sample Lines.

Subpart H Section 61.93 (b) (2) (iii) (100 Appendix N)

Subpart H Section 61.93(b)(2)(iv) (see Appendix N)

Subpart H Section 61.93(b)(3) (noc Appendix N)

Subpart H Section 61.93(b)(4)(i) (noc Appendix N)

Subpart H Section 61.93(b)(4)(ii) (20e Appendix N)

Subpart H Section 61.93(b)(5) (200 Appendix N) 
APPENDIX G

40 CFR 61.93, SUBPART H COMPARISON FOR 296-C-5 

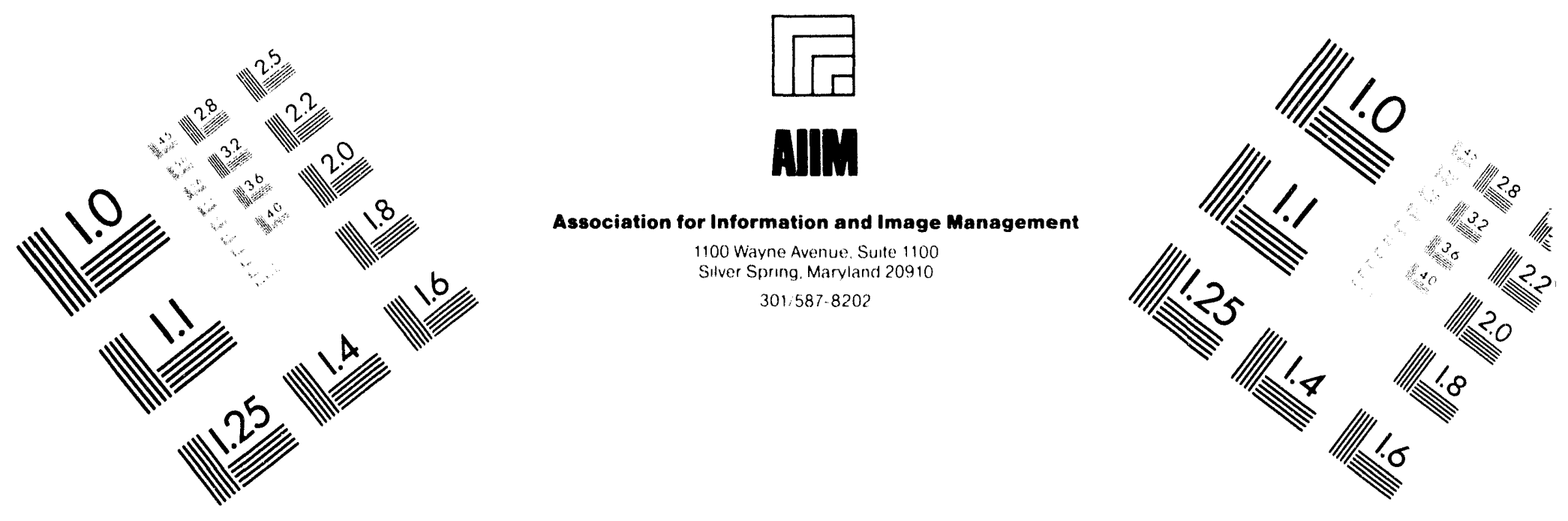

\section{Centimeter}

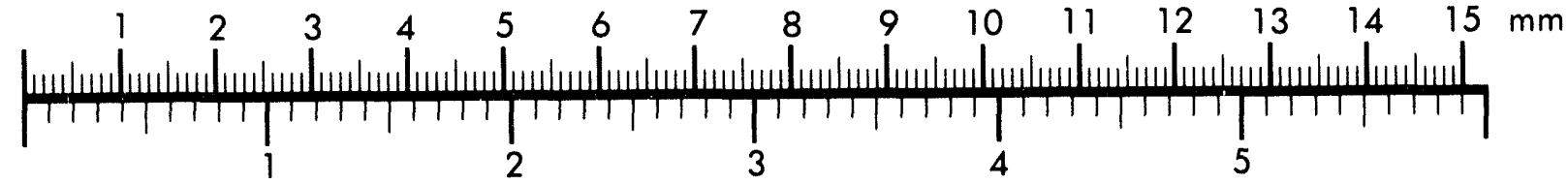

Inches
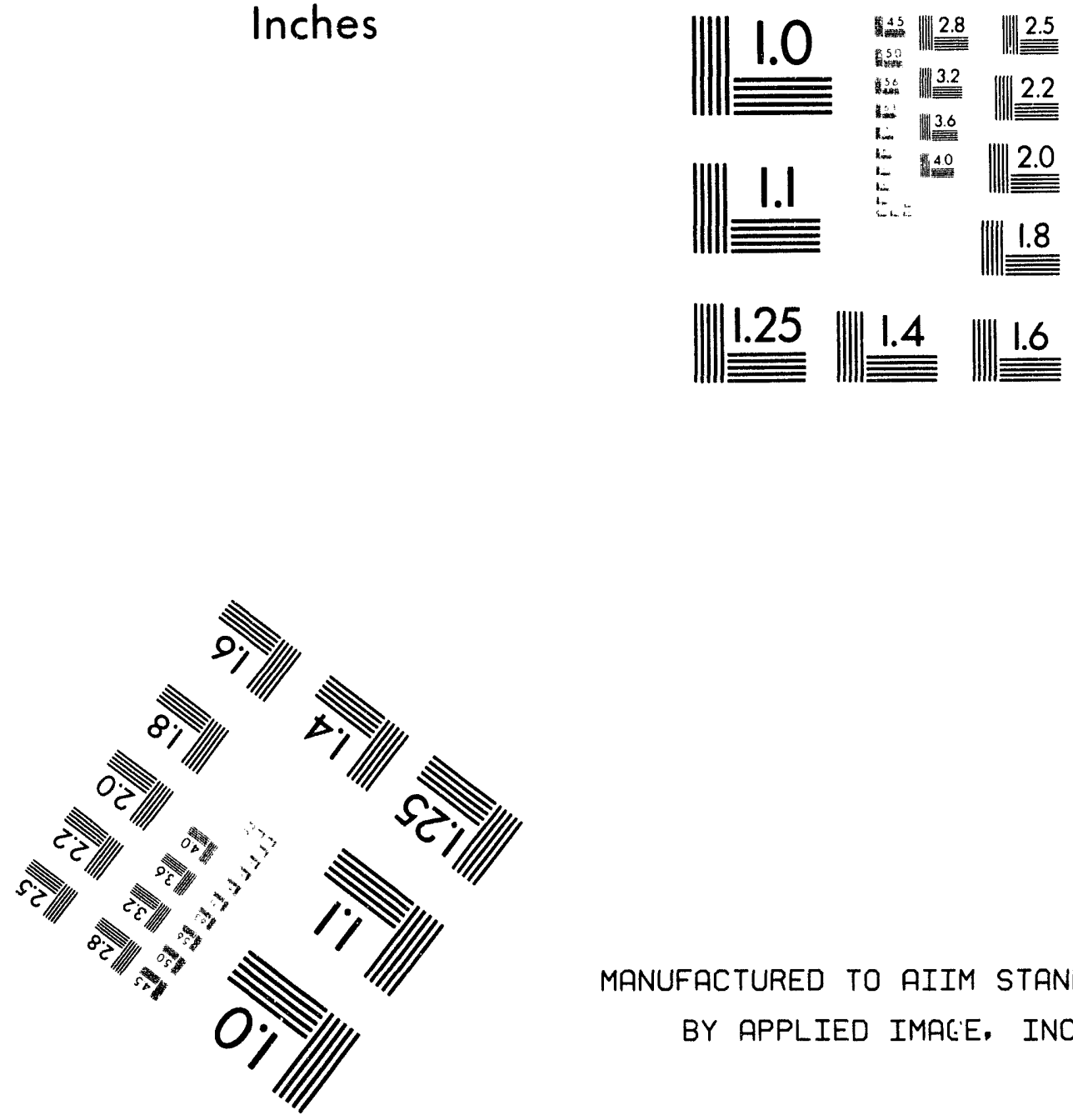

MANUFACTURED TO AIIM STANDARDS

BY APPLIED IMACE, INC.

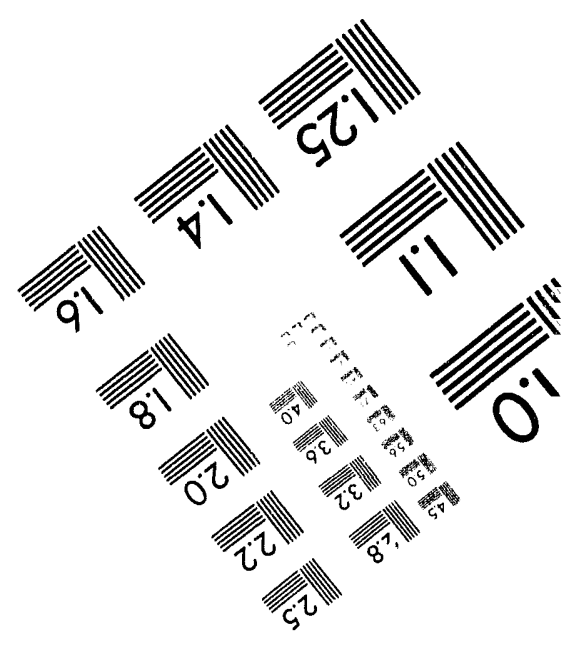



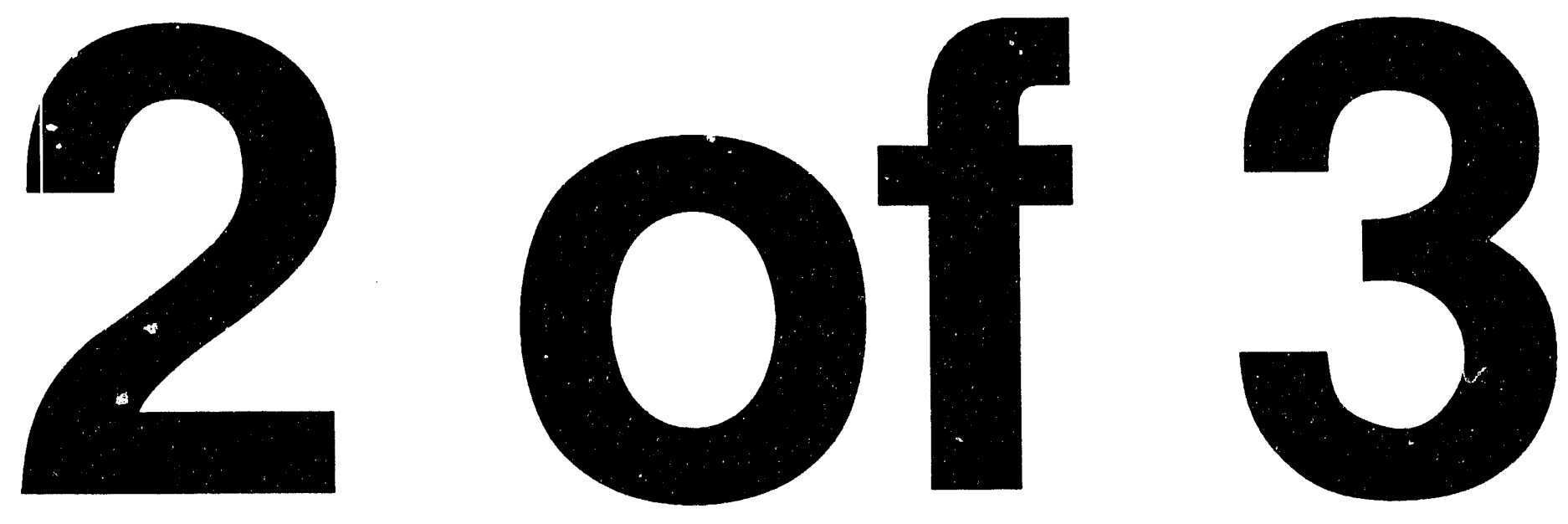
This page intentionally left blank. 


\section{POINT-BY-POINT NESHAP COMPLIANCE COMPARISON FOR THE 244-CR VAULT EXHAUSTER STACK NUMBER 296-C-05}

\section{Subpart H Section 61.93 (a) (coe Appendix N)}

Subpart A Section 61.93 (b) Radionuclide eminsion rates from point cources (atacks or ventu) shall be measured in acoordanoe with the following requirements or procedurea for which EPA has granted prior approval:

Subpart H Section 61.93 (b)(1) Efluent tlow nate measurements athall be made using the following methods:

Subpart H Section 61.93 (b)(1)(i) Reference Method 2 of Appendix A to Part 60 shall be used to determine velocities and volumetric flow rates for atacks and large vents.

40 CFR 60. Appendix A. Method 2 Determination of Stack Gas Velocity and Volumetric Flow Rate (Type S Pitot Tube) Mothod 2 is applicable for measurement of the average volocity of a gas stream and for quantifying gas flow. This procedure is not applicable for:

- cyclonic or swirling gas streams;

- ack diameters smaller than $0.30 \mathrm{~m}$ (12 in.) or atack croes ectional areas less than $0.071 \mathrm{~m}^{2}$ (113in');

- measurement vites which fail to meet the criteria of Method 1 in 40 CFR 60, Appendix A, 82.1)

Documentation: Maintenance Engineering Services Maintenance Procedure 1202, Rev 0

WHC-SD-WM-WP-147, Rev 1

Comparison: The referenced procedure has been written to mirror the 40 CFR 60 , Appendix A, Method 2 procedure. Implementation of this procedure is addressed in the referenced procedure upgrade program.

Implementation involves writing facility specific procedures from the main referenced procedure. The specific procedure development is underway. The measurement site selection requirement is addressed next.

40 CFR 60. Appendix A. Method 1. \& 2.1. Selection of Measurement Site Sampling or velocity measurement is performed at a site located at least eight stack or duct diameters downstream and two diameters upstream from any disturbances wuch as a bend, expansion, or contraction in the stack, or from a visible flame. If necessary, an alternative location may be elected, at a position at least two stack or duct diameters downstream and lose than a half diameter upstream from a flow disturbance. 
Documentation: Drawing H-2-92519

Job Control System Work Packages listed under "Subpart H Section 61.93 (b) (1) (iii)"

\section{GUIDANCE/DATA SHEET 244-CR VAULT EXHAUST STACK (296-C-5) FLOW MEASUREMENT}

Facilities Maintenance Support Services Preventive Maintenance Procedure 7-GN-56, Rev 2

Comparison: This is an 46-cm (18-in.) circular diameter stack. The stack

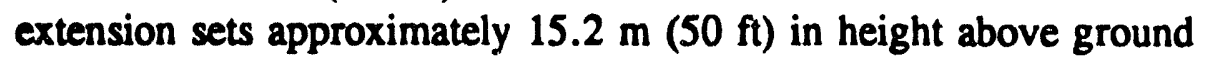
level [202.1 $\mathrm{m}$ (663 ft) above sea level]. The sample probe is located $340 \mathrm{~cm}$ (134 in.) above the fan discharge into the stack (7.4 duct diameters) and $991 \mathrm{~cm}(390 \mathrm{in}$.) below the top of the stack (21.7 duct diameters). There is a single port $1.07 \mathrm{~m} \mathrm{(42} \mathrm{in.)} \mathrm{(2.3}$ duct diameters) above the fan discharge into the stack and $2.34 \mathrm{~m}$ (92 in.) (5.1 duct diameters) below the sample probe location in the stack. There are 16 annular traverse measurements taken from this port. Each traverse point is located according to Table 1-2, "Location of Traverse Points in Circular Stacks" of Method 1, of Appendix A of 40 CFR 60.

Subpart H Section 61.93 (b)(1)(ii) Reference Method 2A of Appendix A to Part 60 shall be used to determine velocities and volumetric how rates through pipes and small ducts.

Documentation: None.

Comparison: Method 2A is not applicable for stacks. If is applicable for pipes and ducts where the entire effluent is run through a measuring device. This method may be applicable to the sampling systems themselves.

Subpart H Section 61.93 (b)(1)(iii) The frequency of tlow' nate measurements shall depend upon the variability of the eflluent flow rate. For variable flow ntes, continuous or frequent flow ntes measurements shall be made. For relatively constant flow rates only periodic measurements are noceasary.

Documentation: The following flows were obtained from this facility. Note, where available the Job Control System Work Package number and date the measurement was taken is given:

$$
\text { DATE ELOW }\left(\mathrm{ft}^{3} / \mathrm{min}\right) \quad \text { WP\# }
$$

$\begin{array}{lll}01 / 09 / 91 & 1,092 & \text { NONE } \\ 04 / 18 / 91 & 1,392 & 2 \mathrm{E} 35017 \\ 07 / 16 / 91 & 1,408 & \text { NONE }\end{array}$




$\begin{array}{lll}11 / 24 / 92 & 3,085 & 2 \mathrm{E}-92-01248 \\ 03 / 08 / 93 & 2,894 & 2 \mathrm{E}-93-00156 \\ 04 / 28 / 93 & 3,012 & 2 \mathrm{E}-93-00572 \\ 07 / 21-93 & 3,697 & 2 \mathrm{E}-93-00956\end{array}$

AVERAGE 2,369

VARIABILITY $-54 \% /+56 \%$

STANDARD DEVIATION $\quad 1,039$

95\% CONFIDENT INTERVAL 2,542

RANGE Too variable

Comparison: Although the regulations do not specifically define variable versus constants flow rate, a flow rate with a variability of less than \pm 20 percent has been defined at the Hanford Site as being continuous. This criteria is specified in SD-WM-CR-016. The flow rates given above are therefore, variable. The schedule for taking these flows is quarterly. Although the quarterly schedule is not always met, the requirement at the Hanford Site is to take flow rates at least annually when the exhauster is running. This exhauster runs continuously except for maintenance.

Subpart H Section 61.93 (b)(2) Radionuclidea shall be directly monitored or extracted, collected and measured using the following methods:

Subpart H Section 61.93 (b)(2)(i) Reference Method 1 of Appendix A Part 60 shall be used to select monitoring or sampling sites.

40 CER 60. Appendix A. Method 1. Sample and Velocity Traverses for Stationary Sources

40 CFR 60. Appendix A. Method 1. Section 1.2: Applicability This method is applicable to flowing gas atreams in ducts, atacks, and flues. This method cannot be used when: (1) flow is cyclonic or swirling (cee eoction 2.4); (2) a stack is smaller than about $0.30 \mathrm{~m}$ (12 in.) in diameter, or $0.071 \mathrm{~m}^{2}\left(113 \mathrm{in.}^{2}\right)$ cross-ectional area; or (3) the measurement site is less than two stack or duct diameters downstream or less than a half diameter upstream from a flow disturbance.

Documentation: Drawing H-2-92519

Comparison: This stack is 18 in. in diameter and therefore this method is applicable.

40 CFR 60. Appendix A. Method 1, Section 2.1: Selection of Measurement Site Sampling or velocity mearurement is performed at a site located at least eight stack or duct diameters downstream and two diameters upstream from any disturbances such as a bend, expansion, or contraction in 
the atack, or from a visible flame. If neceseary, an alternative location may be selected, at a position at least two atack or duct diametors downatream and a half diameter upatream from any flow diaturbance.

Documentation: Drawing H-2-92519

Comparison: Also see comparison under 40 CFR 60, Appendix A, Method 1, \$ 2.1, Selection of Measurement Site, under " 40 CFR 60, Appendix A, Method 2, Determination of Stack Gas Velocity and Volumetric Flow Rate (Type S Pitot Tube)" above. This is a 46-cm (18 in.) circular diameter stack which extends approximately $15.2 \mathrm{~m}$ (50 $\mathrm{ft}$ ) in height above the ground level. The sample probe is located $3.40 \mathrm{~cm}$ (134 in.) above the fan discharge into the stack ( 7.4 duct diameters) and $9.91 \mathrm{~m}(390 \mathrm{in}$.) below the top of the stack ( 21.7 duct diameters).

Subpart H Section 61.93 (b) (2) (ii) The effluent atream shall be directly monitored continuously with an in-line detector or representative samples of the eflluent stream shall be withdrawn continuously from the sampling site following the guidance presented in ANSI N13.1-1969 "Guide to Sampling Airbome Radioactive Materiale in Nuclear Facilities" (including the guidanoe presented in Appendix A of ANSIN13.1).

ANSI N13.1-1969. Guide to Sampline Airborne Radioactive Materials in Nuclear Facilities The guidance for this standard begins in Section 4.0 Principles. Section 4.1 is General, Section 4.2 is Representative Samples, Section 4.2.1 is Samples Representative Acconding to Spacial Location, Section 4.2.1.1 is Sampling in a Zone Occupies by Workers. The firat eaction in this ANSI atandard applicable to the comparison of this document is 4.2.1.2.

\section{ANSI N13.1-1969. Section 4,2.1.2, Sampling from a Duct or Exhaust Stack}

Sampling point should be a minimum of 5 diameters (or 5 times the major dimension for rectangular ducts) downstream from abrupt changes in flow direction or prominent transitions.

Not applicable. 40 CFR 61.93 (b)(2)(i) specifies the site location. See comparison under "Method 1, Section 2.1: Selection of Measurement Site."

\section{ANSI N13.1-1969. Section 4.2.2. Samples Representative with Respect to Physical} and Chemical Composition These subections (4.2.2.1, 4.2.2.2, 4.2.2.3, and 4.2.2.4) discuss losses in general. These sections touch on chemical composition of the stream being sampled, particle size, probe location, delivery lines, collection filters, and refers to Appendixes B and C of the standard.

Documentation: WHC-SD-WM-ES-291, Rev 1

$$
\text { WHC-SD-WM-EMP-031, Rev 0, }
$$

Comparison: Particle size studies have not been performed at this facility. Particle loss determination has been accomplished. (refer to WHC-SD-WM-ES-291). See comparison under ANSI N13.1-1969, Appendix B below. 
Information provided in WHC-SD-WM-EMP-031 suggest that the sample should consist mainly of ${ }^{89 / 90} \mathrm{Sr},{ }^{137} \mathrm{CS},{ }^{239 / 210} \mathrm{Pu}$, and ${ }^{241} \mathrm{Am}$. These radionuclides are particulate in nature. They are not volatile.

ANSI N13.1-1969. Section 4.3. Sample Programming Many factors enter into the design of a sampling program. The sampling program includes the frequency, duration, and volume rate of sampling. In most cases, the selection of these three elements in programming will be a compromice between idea values and those which provide safety and yet are technically, aconomically, and conveniently achieved.

ANSI N13.1-1969. Section 4.3.1 (200 Appendix N)

ANSI N13.1-1969. Section 4.3.2 (200 Appendix N)

ANSI N13.1-1969. Section 4.3.3 (co Appendix N)

ANSI N13.1-1969. Section 4.3.4 (coe Appendix N)

ANSI N13.1-1969. Section 4.3.5 (200 Appendix N)

ANSI N13.1-1969. Section 5. Methods

ANSI N13.1-1969. Section 5.1. General Two forms of airborne radioactive materials are particulate and gases; the particles can be colid or liquid, although particulates are generally considered to be very small fragments of solids. . .

Documentation: WHC-SD-WM-EMP-031, Rev 0

Comparison: Information provided in WHC-SD-WM-EMP-031 suggest that the sample should consist mainly of ${ }^{8990} \mathrm{Sr},{ }^{137 \mathrm{C}} \mathrm{S},{ }^{239210} \mathrm{Pu}$ and ${ }^{241} \mathrm{Am}$. These radionuclides are particulate in nature and are not volatile.

\section{ANSI N13.1-1969. Section 5.2. Particles}

ANSI N13.1-1969. Section 5.2.1. Sample Delivery Principles concerning the removal of a representative portion of a contained atream, as from a large duct, have been presented in Section 4 . . .

ANSI N13.1-1969. Section 5.2.2. Particle Collectors without Significant Size Differentiation Various collectors are applicable to sampling airborne radioactive materials. . .

ANSI N13.1-1969. Section 5.2.2.1 (see Appendix N)

ANSI N13.1-1969. Section 5.2.2.1.7 (see Appendix N)

ANSI N13.1-1969. Section 5.3. Gases Airborne radioactive volatile materials and so-called "permanent gases such as tritium are frequently important contaminants and their sampling and collection requires techniques and methods differing from those used in particle sampling. . . 
Documentation: WHC-SD-WM-EMP-031, Rev 0

Comparison: No volatile radionuclides are present at this facility.

ANSI N13.1-1969. Section 6.0 (coe Appendix N)

ANSI N13.1-1969. Appendix A. Section A1 Minimization of the length and bends of rample delivery lines will contribute to representative sampling.

Documentation: Drawing H-2-92519

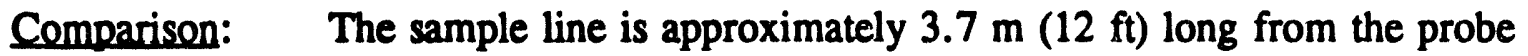
connection outside the stack to the top of the sample cabinet. There is a less-than $-90^{\circ}$ bend (approximately $75^{\circ}$ ) located just outside the stack at the sample point which is designed to have a bend radius of less than $19 \mathrm{~cm}(7.5$ in.). There is another gradual bend (approximately $15^{\circ}$ ) located approximately $.6 \mathrm{~m}(2 \mathrm{ft}$ ) above the sample cabinet. The tubing is $1.9 \mathrm{~cm}(3 / 4 \mathrm{in}$.) $0 . D$. X $0.09 \mathrm{~cm}$ $(0.035 \mathrm{in}$.) WALL. This makes the inside diameter $1.7 \mathrm{~cm}$ (0.68 in.).

ANSI N13.1-1969. Appendix A. Section A2 The distance from the last upatream disturbance to the point of ample extraction ahould be a minimum of five and preferably ten or more duct diameters downstream. Sampling from a vertical run avoids stratification due to gravity settling. Sampling as far downstream as possible avoids most transient variation in airstream quality.

Not applicable. 40 CFR 61.93 (b)(2)(i) specifies the site location. See comparison under "Method 1, Section 2.1: Selection of Measurement Site."

ANSI N13.1-1969. Appendix A. Section A3.1 Velocity and flow distribution should be known for the sampling point, and particle and gasoous composition should be representative.

Documentation: Not applicable.

Comparison: Velocity measurements are accomplished by Facilities Maintenance Support Services Preventive Maintenance Procedure 7-GN-56, Rev 2, Airflow Capacity and Distribution Tests in conjunction with supplemental GUIDANCE/DATA SHEET, 244-CR VAULT EXHAUST STACK (296-C-5) FLOW MEASUREMENT. From the section above, "Subpart H Section 61.93 (b)(1)(iii)," the average flow rate was $67,078 \mathrm{~L} / \mathrm{min}\left(2,369 \mathrm{ft}^{3} / \mathrm{min}\right)$. For an $46-\mathrm{cm}$ (18-in.) stack, this amounts to a velocity of $6.80 \mathrm{~m}(22.3 \mathrm{ft}) /$ second. According to Table A1 in the ANSI N13.1-1969 Standard laminar flows occur below $.21 \mathrm{~m}(0.68 \mathrm{ft}) / \mathrm{second}$. Above that turbulent flows exist. According to ANSI N13.1-1969 Section A3.3.2 "as the flow becomes more turbulent, the velocity becomes more nearly 
uniform across the duct." Significant duct diameters do exist for the flow profile to be uniform according to Method 1 (see comparison discussion under "Method 1, Section 2.1: Selection of Measurement Site"). Figure G-1 is a plot of the velocity distribution, which is based on a very limited amount of data. Note that the sampling location is $\mathbf{5 . 1}$ duct diameters downstream from the flow measurement location. Since there are no flow disturbances between the flow measurement location and the sampling location, the distribution at the sampling location should be much more uniform. Use the following equation to convert from velocity pressure (inches water, gauge) to velocity (feet per minute).

Velocity $=4005 * \sqrt{\text { VelocityPressure }}$ 
Figure G-1. Stack Flow Distribution 296-C-5-A.

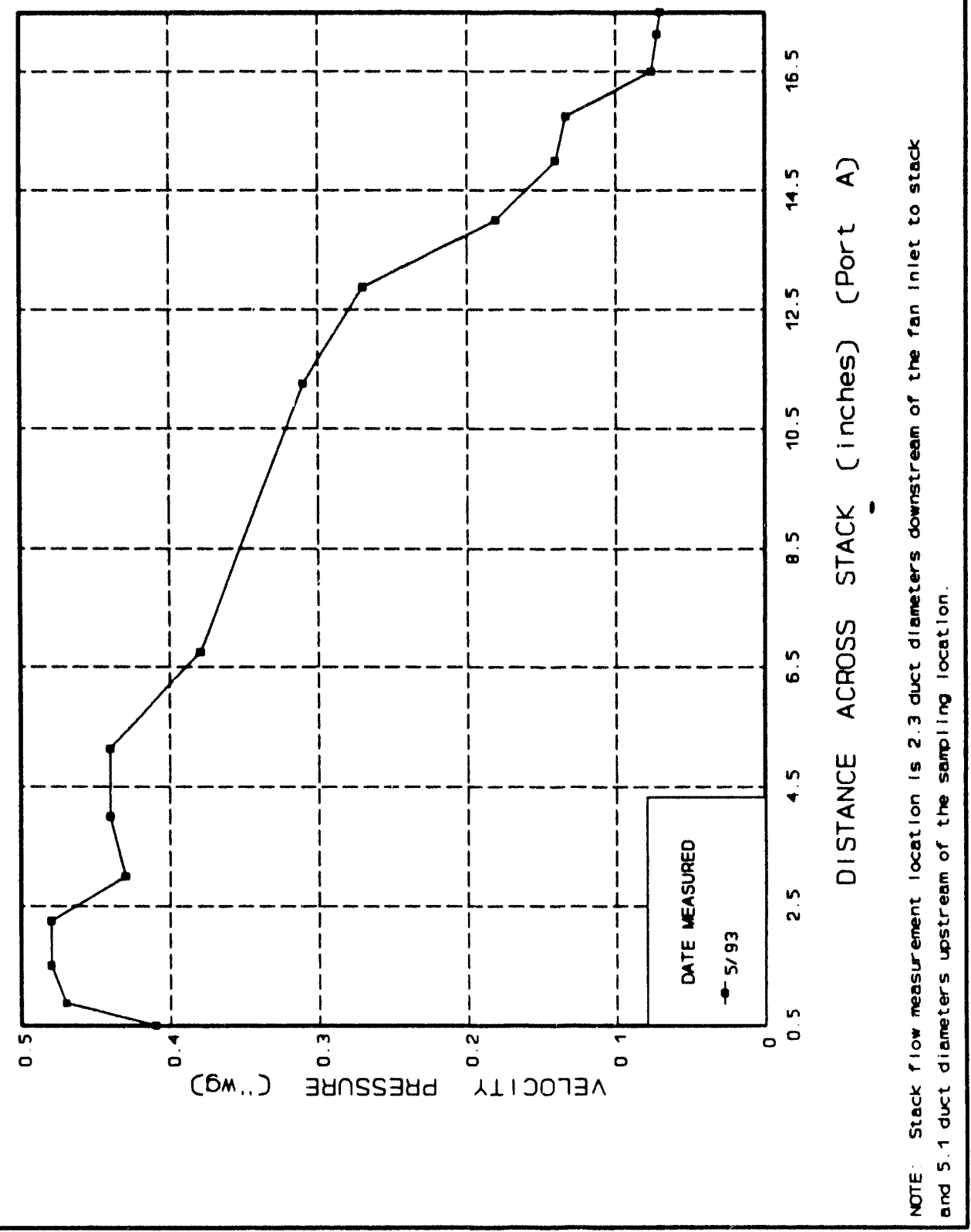


ANSI N13.1-196i. Appendix A. Section A3.2 A multiple number of withdrawal points each representing approximatoly equal areses basod on the duct or atack dimensions is desirable.

Documentation: Drawing H-2-92523

Comparison: This drawing shows the probe with a single nozzle. The nozzle is located approximately $13 \mathrm{~cm}(5 \mathrm{in}$.) off from the center line of the stack.

ANSI N13.1-1969. Appendix A. Section A3.3 The velocity distribution across the duct or stack ahould be known in order to ectabliah isokinetic flow and represontative sample points.

Documentation: Not applicable.

Comparison: The designed isokinetic flow rate in the stack is $43,661 \mathrm{~L} / \mathrm{min}$ $\left(1,542 \mathrm{ft}^{3} / \mathrm{min}\right)$, based on a sample flow of $62.3 \mathrm{~L} / \mathrm{min}\left(2.2 \mathrm{ft}^{3} / \mathrm{min}\right)$. Although, it is not reasonable to assume that the design flow is maintained. To determine the true or actual operating condition isokinetic flow rate sample data as well as instrumentation errors must be accounted for. From 1992 data, it can be shown that the actual sample flow at the sample nozzle opening (taking into account variability in the readings and instrumentation errors) is from 42.5 to $65.1 \mathrm{~L} / \mathrm{min}\left(1.5\right.$ to $\left.2.3 \mathrm{ft}^{3} / \mathrm{min}\right)$. From this, the actual or operating isokinetic flow rate in the stack is from 29,759 to $45,643 \mathrm{~L} / \mathrm{min}$ (1,051 to $1,612 \mathrm{ft}^{3} / \mathrm{min}$ ). Section Subpart $\mathrm{H}$ Section 61.93 (b)(1)(iii) above gives the actual flow rates measured in the stack. The average of this data is $67,078 \mathrm{~L} / \mathrm{min}\left(2,369 \mathrm{ft}^{3} / \mathrm{min}\right)$ with a minimum and maximum flow rate between 30,920 to $104,680 \mathrm{~L} / \mathrm{min}(1,092$ and $\left.3,697 \mathrm{ft}^{3} / \mathrm{min}\right)$.

ANSI N13.1-1969. Appendix A. Section A3,4 Sampling probe configuration is recommended by figures in this ANSI standard, with minimum radius bends and preciecly tapered probe end edges.

Documentation: Drawing H-2-92523

Comparison: This drawing shows the probe nozzles as $3 / 4 \mathrm{in}$. OD by 0.035 WALL. This gives the ID as $1.73 \mathrm{~cm}(0.68 \mathrm{in}$.). The nozzle has a $8.9-\mathrm{cm}(3.5-\mathrm{in}$.$) minimum bend radius and is approximately 8.9-\mathrm{cm}$ ( 3.5 in.) in length under the bend radius. According to ANSI, the bend radius, and the vertical should both be 5 times the inside diameter. Five times the inside diameter of this probe is $3.6 \mathrm{~cm}$ (1.4 in.). In addition the nozzle is tapered to a knife edge.

Therefore, the sampling probe complies with this section of ANSI.

ANSI N13.1-1969. Appendix B. Particle Deposition in Sample Lines 
Documentation: WHC-SD-WM-ES-291, Rev 1

Comparison: The estimate made for this stack was made using an up-to-date computer software program. The program title is "DEPOSITION 2.0" and is referenced as Anand, N. K., McFarland, A.R., Wong, F.S, Kocmound C.J., DEPOSITION 2.0, NRC NuReg/GR-006, Serial \# 2145, March 8, 1993, Aerosol Technology Laboratory, De partment of Mechanical Engineering, Texas A\&M University College Station, TX 77843. This program also provides for anisokinetic sampling affects as discussed in ANSI N13.1-1969, Appendix C.

Because particle sizes are not known a spread of particle sizes were used (i.e., 10, 3.5 and 1 micron in size). The results are as follows:

STACK NUMBER 296-C-5 SAMPLING SYSTEM PARTICLE PENETRATION PERCEIVTAGE

\begin{tabular}{|c|c|c|c|c|c|c|}
\hline & \multicolumn{5}{|c|}{ PARTICLE SIZE } \\
\hline Range & \multicolumn{2}{|c|}{$10 \mu \mathrm{m}$} & \multicolumn{2}{c|}{$3.5 \mu \mathrm{m}$} & \multicolumn{2}{c|}{$1 \mu \mathrm{m}$} \\
\hline & Probe & Total & Probe & Total & Probe & Total \\
\hline Minimum & 91.4 & 52.5 & 97.3 & 91.6 & 99.2 & 98.6 \\
\hline Average & 110.4 & 69.2 & 100.4 & 95.2 & 99.6 & 99.0 \\
\hline Maximum & 165.3 & 109.7 & 110.1 & 104.7 & 100.5 & 100.1 \\
\hline
\end{tabular}

The variables used in this program are as follows:

Stack diameter 18 in $=0.4572 \mathrm{~m}$

Area $=\pi R^{2}=0.16417 \mathrm{~m}^{2}$

Stack Stream Velocity $(\mathrm{m} / \mathrm{s}): 3.14$ to 10.63

Average: 6.81

Probe Equivalent Radius $=0.34$ in

Probe Equivalent Diameter $=0.68 \mathrm{in}=17.272 \mathrm{~mm}$

Designed Sample Flow Rate $=2.2 \mathrm{ft}^{3} / \mathrm{min}=62.29696 \mathrm{~L} / \mathrm{min}$

Sample Flow rate $(\mathrm{L} / \mathrm{min}): 42.48$ to 65.13

Average: 53.80 
Line Length $=12 \mathrm{ft}=3.6576 \mathrm{~m}$ Tube $\mathrm{ID}=0.68$ in $=17.272 \mathrm{~mm}$ two $45^{\circ}$ bends

ANSI N13.1-1969. Appendix C. Errors Due to Anisokinetic Sampling Evaluated with the software discussed above under ANSI N13.1-1969, Appendix B, Particle Deposition in Sample Lines.

Subpart H Section 61.93 (b)_(2) (iii) (sec Appendix N)

Subpart H Section 61.93(b)(2)(iv) (sec Appendix N)

Subpart H Section 61.93(b)(3) (roe Appendix N)

Subpart H Section 61.93(b)(4)(i) (sec Appendix N)

Subpart H Section 61.93(B)(4)(ii) (sec Appendix N)

Subpart H Section 61.23(b)(5) (coe Appendix N) 
This page intentionally left blank. 
APPENDIX H

40 CFR 61.93, SUBPART H COMPARISON FOR 296-P-16 
This page intentionally left blank. 


\section{POINT-BY-POINT NESHAP COMPLIANCE COMPARISON FOR THE 241-C-105/106 TANK FARM EXHAUSTER EXHAUSTER STACK NUMBER 296-P-16}

Subpart H Section 61.93 (a) (coe Appendix N)

Subpart H Section 61.93 (b) Radionuclide emission rates from point sources (stacks or vents) shall be measurod in accordance with the following requirements or procedures for which EPA has granted prior approval:

Subpart H Section 61.93 (b)(1) Efluent flow rate measurements athall be made using the following methods:

Subpart H Section 61.93 (b)(1)(i) Reference Method 2 of Appendix A to Part 60 athall be unod to determine velocities and volumetric flow ratos for atacks and large vents.

40 CFR 60. Appendix A. Method 2 Dotormination of Stack Gas Volocity and Volumetric Flow Rate (Type S Pitot Tube) Method 2 is applicable for measurement of the average velocity of a gas stream and for quantifying gas flow. This procodure is nef applicable for:

- Cyclonic or awirling gas streams;

- Stack diameters amaller than $0.30 \mathrm{~m}$ (12 in.) or stack cross sectional areas less than $0.071 \mathrm{~m}^{2}$ $\left(113 \mathrm{in}^{2}\right)$;

- Meanrement aitos which fail to moet the criteria of Method 1 in 40 CFR 60, Appendix A, 8.1)

Documentation: Maintenance Engineering Services Maintenance Procedure 1202, Rev 0

WHC-SD-WM-WP-147, Rev 1

Comparison: The referenced procedure has been written to mirror the 40 CFR 60 , Appendix A, Method 2 procedure. Implementation of this procedure is addressed in the referenced procedure upgrade program.

Implementation involves writing facility specific procedures from the main referenced procedure. The specific procedure development is underway. The measurement site selection requirement is addressed next.

40 CFR 60. Appendix A. Method 1, 2.1. Selection of Measurement Site Sampling or velocity measurement is performed at a site located at least eight stack or duct diametors downstream and two diameters upstream from any disturbances wch as a bend, expansion, or contraction in the stack, or from a visible flame. If necesary, an alternative location may be selectod, at a position at least two stack or duct diameters downstream and less than a half diameter upstream from a flow disturbance. 
Documentation: Drawing H-2-95268

Job Control System Work Packages listed under "Subpart H Section 61.93 (b) (1) (iii)"

\section{GUIDANCE/DATA SHEET FOR 241-C-105/106 EXHAUSTER STACK (296-P-16) FLOW MEASUREMENT}

\section{Facilities Maintenance Support Services Preventive Maintenance} Procedure 7-GN-56, Rev 2

Comparison: This is a 41-cm (16-in.) circular diameter stack (16 gauge). The stack extension sets approximately $3.0 \mathrm{~m}$ (10 ft) in height above the fan discharge. The sample probe is located $89 \mathrm{~cm}(35 \mathrm{in}$.) below the top of the stack and $2.2 \mathrm{~m}$ ( $85 \mathrm{in}$.) above bottom of the stack extension (closest upstream flow disturbance). The finished grade that this stack sets on is at an elevation of $196.69 \mathrm{~m}(645.3 \mathrm{ft})$ above sea level. There are two ports 90 degrees apart approximately $8 \mathrm{~cm}$ ( 3 in.) [ $2.08 \mathrm{~m}$ ( 82 in.) above the bottom of the stack extension] below the sample probe centerline. The nozzle openings of the sample probe are a maximum of $11.4 \mathrm{~cm}(4.5 \mathrm{in}$.) below the probe centerline. Because of this, only one of these ports can be used for flow measurements. There are 16 annular traverse measurements taken from this port. Each traverse point is located according to Table 1-2, "Location of Traverse Points in Circular Stacks" of Method 1, of Appendix A of 40 CFR 60.

Subpart H Section 61.93 (b)(1)(ii) Reference Method 2A of Appendix A to Part 60 shall be used to determine velocities and volumetric flow rates through pipes and small ducts.

Documentation: None.

Comparison: Method $2 \mathrm{~A}$ is not applicable for stacks. If is applicable for pipes and ducts where the entire effluent is run through a measuring device. This method may be applicable to the sampling systems themselves.

Subpart H Section 61.93 (b)(1)(iii) The frequency of flow rate measurements shall depend upon the variability of the effluent flow rate. For variable flow rates, continuous or frequent flow rates measurements shall be made. For relatively constant flow rates only periodic measurements are necessary. 
Documentation: The following flc ws were obtained from this facility. Note, where available the Job Control System Work Package number and date the measurement was taken is given:

\begin{tabular}{|c|c|c|}
\hline Date & Flow $\left(\mathrm{ft}^{3} / \mathrm{min}\right)$ & WP\# \\
\hline $11 / 15 / 90$ & 3,034 & NONE \\
\hline $01 / 09 / 91$ & 3,682 & NONE \\
\hline $04 / 15 / 91$ & 2,772 & NONE \\
\hline $07 / 08 / 91$ & 3,049 & NONE \\
\hline $06 / 07 / 92$ & 3,020 & $2 \mathrm{E}-92-00274$ \\
\hline $10 / 29 / 92$ & 3,045 & $2 \mathrm{E}-92-01247$ \\
\hline $03 / 08 / 93$ & 3,951 & $2 \mathrm{E}-93-00136$ \\
\hline
\end{tabular}

$\begin{array}{lc}\text { AVERAGE } & 3,222 \\ \text { VARIABIITY } & -14 \% /+23 \% \\ \text { STANDARD DEVIATION } 425 \\ \text { 95\% CONFIDENT INTERVAL } 1,040 \\ \text { RANGE } 2,182 \text { to } 4,261\end{array}$

Comparison: Although the regulations do not specifically define variable versus constants flow rate, a flow rate with a variability of less than \pm 20 percent has been defined at the Hanford Site as being continuous. This criteria is specified in SD-WM-CR-016. The flow rates given above are therefore, variable. The schedule for taking these flows is quarterly. Although the quarterly schedule is not always met, the requirement at the Hanford Site is to take flow rates at least annually when the exhauster is running. This exhauster runs continuously except for maintenance.

Subpart H Section 61.93 (b)(2) Radionuclides shall be directly monitored or extracted, collected and measured using the following metboda:

Subpart H Section 61.93 (b)(2)(i) Reference Method 1 of Appendix A Part 60 shall be used to select monitoring or sumpling sites.

40 CFR 60. Appendix A. Method 1 Sample and Velocity Traverses for Stationary Sources.

40 CER 60. Appendix A. Method 1. Section 1.2: Applicability This method is applicable to flowing gas streams in ducts, stacks, and flues. This method cannot be used when: (1) flow is cyclonic or swirling (eec Section 2.4); (2) a stack is smaller than about $0.30 \mathrm{~m}$ (12 in.) in diameter, or 0.071 $\mathrm{m}^{2}$ (113 in. ${ }^{2}$ ) crose-ectional area; or (3) the measurement site is less than two stack or duct diameters downstream or less than a half diameter upstream from a flow disturbance. 
Documentation: Drawing H-2-95268

Comparison: This stack is $41 \mathrm{~cm}$ (16 in.) in diameter and therefore this method is applicable.

40 CER 60. Appendbx A. Method 1. Section 2.1: Selection of Measurement Site Sampling or velocity meanurement is performed at a vite located at least eight atack or duct diameters downatream and two diameters upatream from any diaturbances wch a a bend, expansion, or contraction in the atack, or from a vivible flame. If neceseary, an altornative location may be celected, at a position at least two atack or duct diamoters downstream and a half diameter upatream from any flow diaturbance.

Documentation: Drawing H-2-95268

Comparison: Also see comparison under 40 CFR 60, Appendix A, Method 1, 8 2.1, Selection of Measurement Site, under "40 CFR 60, Appendix A, Method 2, Determination of Stack Gas Velocity and Volumetric Flow Rate (Type S Pitot Tube)" above. This is a 41-cm (16-in.) circular diameter stack which extends approximately $3.0 \mathrm{~m}$ $(10 \mathrm{ft})$ in height above the fan discharge. The sample probe is located approximately 2.2 duct diameters below the top of the stack and only 5.3 duct diameters above the bottom of the stack extension which is abuve the fan discharge into the stack.

Subpart H Section 61.93 (b) (2) (iil) The effuent atream shall be diroctly monitored continuously with an in-line detector or representative samples of the effluent stream shall be withdrawn continuously from the sampling site following the guidance preaentod in ANSI N13.1-1969 "Guide to Sampling Airtorme Radionctive Materials in Nuclear Facilitiea" (including the guidance presented in Appendix A of ANSIN13.1).

ANSI N13.1-1969. Guide to Sampling Airborne Radioactive Materials in Nuclear Facilities The guidance of this atandard atart in Section 4. Principles. Section 4.1 is General, Section 4.2 is Represensative Samples, Soction 4.2.1 is Samples Representative According so Spacial Cocation, Section 4.2.1.1 is Sampling in a Zone Occupies by Workers. The firat wection in this ANSI atandard applicable to the comparien of this document is in Section 4.2.1.2.

ANSI N13.1-1969. Section 4.2.1.2. Sampling from a Duct or Exhaust Stack Sampling point ahould be a minimum of five diameters (or 5 times the major dimension for rectangular ducts) downstream from abrupt changes in flow direction or prominent transitions.

Not applicable. 40 CFR 61.93 (b)(2)(i) specifies the site location. See cromparison under "Method 1, Section 2.1: Selection of Measurement Site."

ANSI N13.1-1969. Section 4.2.2. Samples Representative with Respect to Physical and Chemical Composition These subsections (4.2.2.1, 4.2.2.2, 4.2.2.3, and 4.2.2.4) discuss losses in general. These eactions touch on chemical composition of the stream being sampled, particle size, probe location, delivery lines, collection filters, and refers to Appendixes B and C of the standard.

Documentation: WHC-SD-WM-ES-291, Rev 1 


\title{
WHC-SD-WM-EMP-031, Rev 0
}

Cemparison: Particle size studies have not been performed at this facility. Particle loss determination has been accomplished however (refer to WHC-SD-WM-ES-291). See comparison under ANSI N13.1-1969, Appendix B.

Information given in WHC-SD-WM-EMP-031 suggest that the sample should consist mainly of ${ }^{137} \mathrm{Cs}$, and ${ }^{239240} \mathrm{Pu}$. These radionuclides are particulate in nature. They are not volatile.

\begin{abstract}
ANSI N13.1-1969. Section 4.3. Sample Programming Many factors onter into the design of a sampling program. The ampling program iscludes the frequency, duration, and volume rate of ampling. In moet cases the solection of these three elements in programming will be a compromise between idea values and thowe which provide anfoty and yet are tochnically, oconomically, and conveniently achieved.
\end{abstract}

ANSI N13.1-1969. Section 4.3.1 (200 Appendix N)

ANSI N13.1-1969, Section 4.3.2 (ree Appendix N)

ANSI N13.1-1969. Section 4.3.3 (200 Appendix N)

ANSIN13.1-1969. Section 4.3.4 (200 Appendix N)

ANSI N13.1-1969. Section 4.3.5 (coe Appendix N)

\section{ANSI N13.1-1969. Section 5. Methods}

ANSI N13.1-1969, Section 5.1. General Two forms of airborne radioactive materials are particulate and gases; the particles can be solid or liquid, although particulates are generally considered to be very small fragments of solids. . .

Documentation: WHC-SD-WM-EMP-031, Rev 0

Comparison: Information given in WHC-SD-WM-EMP-031 suggest that the sample should consist mainly of ${ }^{137} \mathrm{Cs}$, and ${ }^{241} \mathrm{Am}$. These radionuclides are particulate in nature and are not volatile.

\section{ANSI N13,1-1969, Section 5,2, Particles}

ANSI N13,1-1969. Section 5.2.1. Sample Delivery Principles concerning the removal of a representative portion of a contained stream, as from a large duct, have been presented in Section 4. . .

ANSI N13.1-1969, Section 5.2.2. Particle Collectors without Significant Size Differentiation Various collectors are applicable to sampling airborne radioactive materials. . . . 
ANSIN13.1-1969. Section 5.2.2.1 (200 Appendix N)

ANSI N13.1-1969. Section 5.2.2.1.7 (roe Appendix N)

ANSI N13,1-1969. Section 5.3. Gases Airborne radioactive volatile materials and ro-called "permanont gases auch a tritium are frequently important contaminants and their eampling and collection requires techniques and methods differing from those used in particle sampling. . .

Documentation: WHC-SD-WM-EMP-031, Rev 0

Comparison: No volatile radionuclides are present at this facility

ANSIN13.1-1969, Section 6.0 (100 Appendix N)

ANSI N13.1-1969. Appendix A. Section A1 Minimization of the length and bends of ample delivery lines will contribute to representative sampling.

\section{Documentation: Drawing H-2-95267}

Comparison: The sample line is approximately $2.59 \mathrm{~m}(8.5 \mathrm{ft})$ long from the probe connection outside the stack to the top of the sample cabinet. There is a single bend radius which is designed to be 10 times the diameter of the tubing. The tubing is $1.9 \mathrm{~cm}(3 / 4$ in.) O.D. X $0.17 \mathrm{~cm}$ $(0.065 \mathrm{in}$.$) WALL. This makes the inside diameter 1.57 \mathrm{~cm}$ (0.62 in.).

ANSI N13.1-1969. Appendix A. Section A2 The diatance from the last upstream disturbance to the point of eample extraction ahould be a minimum of five and preferably ten or more duct diameters downatream. Sampling from a vertical run avoids atratification due to gravity eetling. Sampling as far downstream as poesible avoids most transient variation in airstream quality.

Not applicable. 40 CFR 61.93 (b)(2)(i) specifies the site location. See comparison under "Method 1, Section 2.1: Selection of Measurement Site."

ANSI N13.1-1969. Appendix A. Section A3.1 Velocity and flow distribution should be known for the sampling point, and particle and gaseous composition should be representative.

Documentation: None.

Comparison: Velocity measurements are accomplished by Facilities Maintenance Support Services Preventive Maintenance Procedure 7-GN-56, Rev 2, Airflow Capacity and Distribution Tests in conjunction with supplemental GUIDANCE/DATA SHEET FOR 241-C-105/106 EXHAUSTER STACK (296-P-16) FLOW MEASUREMENT. From the section above, "Subpart H Section 61.93 (b)(1)(iii)," the average flow rate was seen to be $91,230 \mathrm{~L} / \mathrm{min}\left(3,222 \mathrm{ft}^{3} / \mathrm{min}\right)$. For a 
$40.6 \mathrm{~cm}$ (16 in.) stack, this amounts to a velocity of $11.73 \mathrm{~m}$ (38.5 ft)/second. According to Table A1 in the ANSI N13.1-1969 Standard laminar flows occur below $.207 \mathrm{~m}(0.68 \mathrm{ft}) /$ second. Above that turbulent flows exist. The velocity distribution at the sampling site is uniform (see Figure H-3), but is based on a limited amount of data. Use the following equation to convert from velocity pressure (inches water, gauge) to velocity (feet per minute).

Velocity $=4005 * \sqrt{\text { VelocityPressure }}$ 
Figure H-3. Stack Flow Distribution 296-P-16-A.

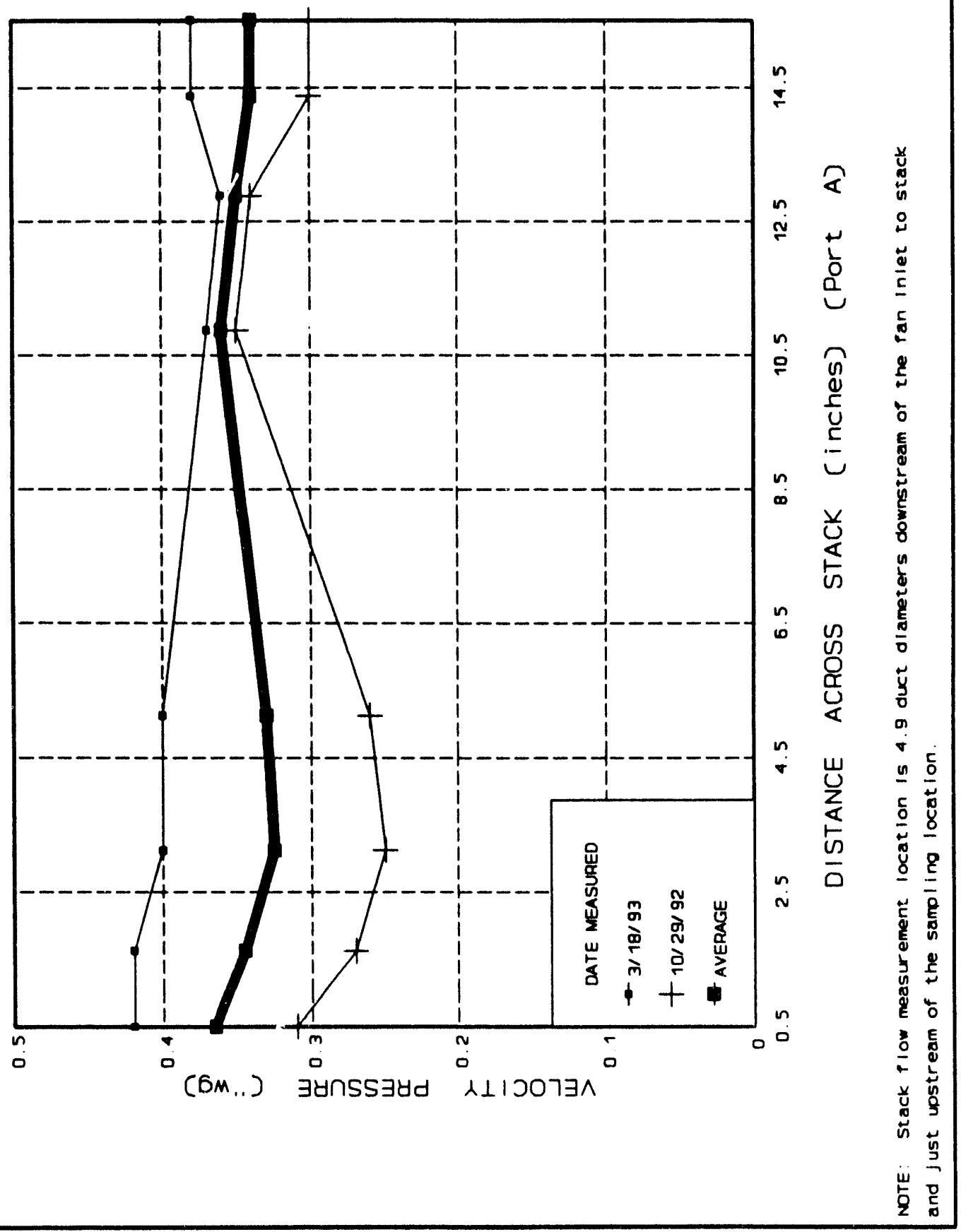


ANSIN13.1-1969. Appendix. A. Section A3.2 A multiple number of withdrawal points each representing approximately equal aren based on the duct or ack dimensions is desirable.

Documentation: Drawing H-2-95269

Comparison: This drawing shows the probe with three nozzles. Each nczzle is located approximately in the center of each of 3 equal annular areas. This is as recommended in this section of the ANSI N13.1-1969 Standard for this size stack (16 in.).

ANSI N13.1-1969. Appendix A. Section A3.3 The volocity distribution acroes the duct or atack should be known in order to extablich isokinetic flow and representative cample points.

Documentation: None.

Comparison: The velocity distribution is not known.

The designed isokinetic flow rate in the stack is $90,381 \mathrm{~L} / \mathrm{min}$ $\left(3,192 \mathrm{ft}^{3} / \mathrm{min}\right)$, based on a sample flow of $62.3 \mathrm{~L} / \mathrm{min}\left(2.2 \mathrm{ft}^{3} / \mathrm{min}\right)$. Although, it is not reasonable to assume that the design flow is maintained. To determine the true or actual operating condition isokinetic flow rate sample data as well as instrumentation errors must be accounted for. From 1992 data, it can be shown that the actual sample flow at the sample nozzle openings (taking into account variability in the readings and instrumentation errors) is from 42.5 to $65.1 \mathrm{~L} / \mathrm{min}\left(1.5\right.$ to $\left.2.3 \mathrm{ft}^{3} / \mathrm{min}\right)$. From this, the actual or operating isokinetic flow rate in the stack is from 61,613 to $94,486 \mathrm{~L} / \mathrm{min}$ $\left(2,176\right.$ to $\left.3,337 \mathrm{ft}^{3} / \mathrm{min}\right)$. Section Subpart H Section 61.93 (b)(1)(iii) above gives the actual flow rates measured in the stack. The average of this data is $91,230 \mathrm{~L} / \mathrm{min}\left(3,222 \mathrm{ft}^{3} / \mathrm{min}\right)$ with a 95 percent confidence interval that the flow rate will be between 61,783 to $120,649 \mathrm{~L} / \mathrm{min}\left(2,182\right.$ to $\left.4,261 \mathrm{ft}^{3} / \mathrm{min}\right)$.

ANSI N13.1-1969. Appendix A. Section A3.4 Sampling probe configuration is recommended by figures in this ANSI Standard, with minimum radius bends and precisely tapered probe end edges.

Documentation: Drawing H-2-95269

Comparison: This drawing provides the probe nozzles as $.79 \mathrm{~cm}(5 / 16 \mathrm{in}$.$) OD by$ $0.09 \mathrm{~cm}(0.035 \mathrm{in}$.) WALL. This gives the ID as $.6160 \mathrm{~cm}$ (0.2425 in.). In addition, each nozzle has a $3.81 \mathrm{~cm}(1.5 \mathrm{in}$.) minimum bend radius and is approximately $9.53 \mathrm{~cm}(3.75 \mathrm{in}$.) in length under the bend radius. According to ANSI the bend radius, as well as the vertical should both be 5 times the inside diameter. Five times the inside diameter of this probe is $3.0798 \mathrm{~cm}$ (1.2125 in.). In addition the nozzle is tapered to a knife edge. 


\section{ANSI N13.1-1969. Appendix B. Particle Deposition in Sample Lines}

Documentation: WHC-SD-WM-ES-291, Rev 1

Comparison: The estimate made for this stack was made using an up-to-date computer software program. The program title is "DEPOSITION 2.0" and is references as N. K. Anand,

A. R. McFarland, F. S. Wong, C. J. Kocmound, DEPOSITION 2.0, NRC NuReg/GR-006, Serial \# 2145, March 8, 1993, Aerosol Technology Laboratory, Department of Mechanical Engineering, Texas A\&M University College Station, TX 77843. This program also provides for anisokinetic sampling affects as discussed in ANSI N13.1-1969, Appendix C.

Since particle sizes are not know a spread of particle sizes were used 10, 3.5 and 1 micron in size. The results are as follows:

Table C20. STACK NUMBER 296-P-16 SAMPLING SYSTEM PARTICLE PENETRATION PERCENTAGE

\begin{tabular}{|c|c|c|c|c|c|c|}
\hline & \multicolumn{5}{|c|}{ PARTICLE SIZE } \\
\hline Range & \multicolumn{2}{|c|}{$10 \mu \mathrm{m}$} & \multicolumn{2}{c|}{$3.5 \mu \mathrm{m}$} & \multicolumn{2}{c|}{$1 \mu \mathrm{m}$} \\
\hline & Probe & Total & Probe & Total & Probe & Total \\
\hline Minimum & 77.5 & 38.4 & 92.9 & 86.6 & 98.0 & 97.3 \\
\hline Average & 94.0 & 54.4 & 96.3 & 90.6 & 98.4 & 97.8 \\
\hline Maximum & 129.9 & 84.0 & 104.7 & 99.5 & 99.3 & 98.8 \\
\hline
\end{tabular}

The variables use in this program are as follows:

Stack diameter 16 in. $=0.4064 \mathrm{~m}$

Area $=\pi R^{2}=0.1297 \mathrm{~m}^{2}$

Stack Stream Velocity $(\mathrm{m} / \mathrm{s}): 7.94$ to 15.50

Average: 11.72

Probe Equivalent Radius $=0.2100$ in.

Probe Equivalent Diameter $=0.4200$ in. $=10.66856695 \mathrm{~mm}$

Designed Sample Flow Rate $=2.2 \mathrm{ft} / \mathrm{min}=62.29696 \mathrm{~L} / \mathrm{min}$

Sample Flow rate (L/min): 42.48 to 65.13 
Average: 53.80

Line Length $=8.5 \mathrm{ft}=2.5908 \mathrm{~m}$ Tube $\mathrm{ID}=0.62 \mathrm{in} .=15.748 \mathrm{~mm}$ one $90^{\circ}$ bend.

ANSL N13.1-1969. Appendix C. Errors Due to Anisokinetic Sampling Evaluated with the software discussed above under ANSI N13.1-1969, Appendix B, Particle Deposition in Sample Lines.

Subpart H Section 61.93 (b) (2) (iii) (soc Appendix N)

Subpart H Section 61.93(b)(2)(iv) (see Appendix N)

Subpart H Section 61.93(b)(3) (200 Appendix N)

Subpart H Section 61.93(b)(4)(i) (sec Appendix N)

Subpart H Section 61.93(b)(4)(ii) (sec Appendix N)

Subpart H Section 61.93(b)(5) (ree Appendix N) 
This page intentionally left blank. 


\section{APPENDIX I}

\section{CFR 61.93, SUBPART H COMPARISON FOR 296-P-23}


This page intentionally left blank. 


\section{POINT-BY-POINT NESHAP COMPLIANCE COMPARISON FOR THE 241-SY TANK FARM EXHAUSTER STACK NUMBER 296-P-23}

\section{Subpart H Section 61.93 (a) (coe Appendix N)}

Subpart H Section 61.93 (b) Radionuclide emistion rates from point sources (atacks or vents) shall be measured in eccordance with the following requirements or procedures for which EPA has granted prior approval:

Subpart H Section 61.93 (b)(1) Emuent flow nate measurements shall be made using the following methods:

Subpart H Section 61.93 (b)(1)(i) Reference Method 2 of Appendix A to Part 60 shall be ueed to determine velocities and volumetric flow rates for atecks and large vents.

Documentation: Drawing H-2-93430

Comparison: $\quad$ Method 2 is for stacks larger than $30 \mathrm{~cm}$ (12 in.). This stack is smaller than the 30-cm (12-in.) applicability criteria; it is only $20 \mathrm{~cm}(8 \mathrm{in}$.$) .$ Method $2 \mathrm{C}$ is applicable for small stacks. See discussion under Method $2 \mathrm{C}$ below.

Subpart H Section 61.93 (b)(1)(ii) Reference Method 2A of Appendix A to Pan 60 shall be used to determine velocities and volumetric flow rates through pipes and amall duets.

Documentation: Not applicable.

Comparison: Method $2 \mathrm{~A}$ is not applicable for stacks. It is applicable for pipes and ducts where the entire effluent is run through a measuring device. This method may be applicable to the sampling systems themselves.

40 CFR 60. Appendix A. Reference 2C Determination of Stack Gas Velocity and Volumetric Flow Rate in Small Stacks or Ducts: This method allows for the following:

1. The selection of the measurement site according to Method 1A in Appendix A of 40 CFR 60 .

2. The selection of the number of traverse point measurements according to Figure 1-2,

"Minimum number of traverse points for velocities (nonparticulate) traverses," in Method 1 in Appendix A of 40 CFR 60.

3. The location of the individual traverse measurement points according to Table 1-2, "Location of Traverse Points in Circular Stacks" of Method 1, of Appendix A of 40 CFR 60.

4. Apparatus

5. Procedure. 
Documentation: Job Control System Work Packages listed under "Subpart H Section 61.93 (b) (1) (iii)"

\section{GUIDANCE, 241-SY PRIMARY EXHAUST STACK FLOW MEASUREMENT}

Facilities Maintenance Support Services Preventive Maintenance Procedure 7-GN-56, Rev 2

\section{Drawing H-2-93427}

Comparison: See the discussion below under "Method 1A, Section 2.1.1: PM Measurement" for selection of the measurement site and requirements. There are two perpendicular ports where this measurements site is located. This site is in the plane of the nozzle opening of the sampler probes. This location is 3 duct diameters below the top of the stack and approximately 6 duct diameters above the fan section of the stack. Figure 1-2 of Method 1 in Appendix A of 40 CFR 60 specifies 12 measurements if the flow disturbances upstream of the site is greater than or equal to 6 duct diameters. Measurements are taken on each of 16 annular traverse points located according to Table 1-2, "Location of Traverse Points in Circular Stacks" of Method 1, of Appendix A of 40 CFR 60. This is performed in each of the two perpendicular flow measurement ports.

A standard pitot tube is used as specified. However, the procedure is not duplicated. A new procedure is under development which will duplicate the regulatory procedure.

Subpart H Section 61.93 (b)(1)(iii) The frequency of flow rate measurements shall depend upon the variability of the effluent flow rate. For variable flow rates, continuous or frequent flow rates, measurements shall be made. For relatively constant how ntes only periodic measurements are necessary.

Documentation: The following flows were obtained from this facility. Note, where available the Job Control System Work Package number and date the measurement was taken is given:

DATE ELOW $\left(\mathrm{ft}^{3} / \mathrm{min}\right) \quad$ WPH

$\begin{array}{lll}09 / 18 / 90 & 747 & \text { NONE } \\ 12 / 13 / 90 & 946 & \text { NONE } \\ 03 / 20 / 91 & 894 & \text { NONE } \\ 04 / 30 / 91 & 780 & \text { 2W-91-00196 } \\ 06 / 18 / 91 & 784 & \text { 2W-91-00539 } \\ 08 / 12 / 91 & 816 & 2 W-91-01003 \\ 09 / 17 / 91 & 855 & 2 W-91-01079\end{array}$




$\begin{array}{lcc}10 / 08 / 92 & 769 & 2 W-92-00785 \\ 02 / 01 / 93 & 974 & 2 W-92-01284 \\ 05 / 05 / 93 & 1,062 & 2 W-93-00318\end{array}$

AVERAGE

VARIABIITY $-13 \% /+23 \%$

STANDARD DEVIATION

Comparison: Although the regulations do not specifically define variable versus constants flow rate, a flow rate with a variability of less than \pm 20 percent has been defined at the Hanford Site as being continuous. This criteria is specified in SD-WM-CR-016. The flow rates given above are therefore, variable. The schedule for taking these flows is quarterly. Although the quarterly schedule is not always met, the requirement at the Hanford Site is to take flow rates at least annually when the exhauster is running. This exhauster does always run.

Subpart H Section 61.93 (b)(2) Radionuclides shall be directly monitored or extracted, collected and measured using the following methods:

Subpart H Section 61.93 (b)(2)(i) Reference Method 1 of Appendix A Part 60 shall be used to select monitoring or sampling sites.

40 CFR 60. Appendix A. Method 1 Sample and Velocity Traverses for Stationary Sources.

\section{CER 60. Appendix A. Method 1. Section 1.2: Applicability This method is} applicable to flowing gas atresms in ducts, stacks, and flues. This method cannot be used when (1) flow is cyclonic or awirling (coc Section 2.4); (2) a stack is smaller than about $0.30 \mathrm{~m}$ (12 in.) in diameter, or 0.071 $\mathrm{m}^{2}$ (113 in. ${ }^{2}$ ) cross-sectional area; or (3) the messurement site is less than two stack or duct diameters downstream or less than a half diameter upstream from a flow disturbance.

\section{Documentation: Drawing H-2-93430}

Comparison: This stack is smaller than the 30-cm (12-in.) applicability criteria; it is only $20.32 \mathrm{~cm}(8 \mathrm{in}$.$) . See Method 1 \mathrm{~A}$ below.

40 CFR 60. Appendix A. Method 1. Section 2.1: Selection of Measurement Site Sampling or velocity mearurement is performed at a site located at least 8 stack or duct diameters downstream and two diamoters upstream from any disturbances such as a bend, expansion, or contraction in the stack, or from a visible flame. If necessary, an alternative location may be selected, at a position at least 2 stack or duct diameters downstream and a half diameter upstream from any flow disturbance. 
Not applicable. This stack is smaller than the $30-\mathrm{cm}$ (12-in.) applicability criteria; it is only $20.32 \mathrm{~cm}$ (8 in.).

40 CER 60. Appendix A. Method 1A. Sample and Velocity Traverses for Stationary Sources with Small Stacks or Ducts This method is applicable to stacks or ducte lese than about $0.30 \mathrm{~m}$ (12 in.) in diameter, or $0.071 \mathrm{~m}^{2}\left(113 \mathrm{in} .^{2}\right)$ crowesectional area, but equal to or greater than about $0.10 \mathrm{~m}$ (4 in.) in diameter or $0.00812 \mathrm{~m}^{2}\left(12.57 \mathrm{in} .^{2}\right)$ in cross-eectional area.

40 CER 60. Appendix A. Method 1A. Section 2.1.1: PM Measurement Method $1 \mathrm{~A}$ calls for the sampling sites to be proforably located at least 8 equivalent stack or duct diameters downstream and 10 equivalent diametors upstream from any flow disturbances. The velocity meanurement location is recommended to be at a site located 8 equivalent stack or duct diametere downstream of the sampling site. This method further atipulates that if auch locations are not available, then the ampling site should be located at least 2 equivaleat stack or duct diameters downstream and $2 \frac{1}{2}$ stack diameters upatream from any flow disturbances. The velocity measurement device should then be located 2 equivaleat atack diameters downatream from the sampling site.

Documentation: Job Conírol System Work Packages listed under "Subpart H Section 61.93 (b) (1) (iii)"

\section{GUIDANCE, 241-SY PRIMARY EXHAUST STACK FLOW MEASUREMENT}

Facilities Maintenance Support Services Preventive Maintenance Procedure 7-GN-56, Rev 2

Drawings H-2-46172, H-2-93427, H-2-93428, H-2-93430

Comparison: This location of the plane of the nozzle opening of the sampler probes is 3 duct diameters below the top of the stack and approximately 6 duct diameters above the fan section of the stack.

Flow measurements are accomplished via Facilities Maintenance Support Services Preventive Maintenance Procedure 7-GN-56, Rev 2. There are two perpendicular ports chosen for the measurement at this same location.

Measurements are taken on each of 16 annular traverse points located according to Table 1-2, "Location of Traverse Points in Circular Stacks" of Method 1, of Appendix A to this same regulation. This is performed in each of the two perpendicular flow measurement ports. 
Subpart H Section 61.93 (b) (2) (ii) The effluent atream shall be directly monitorod continuously with an in-line detector or representative samples of the effluent atream shall be withdrawn continuously from the sampling vite following the gilidence prosented in ANSI N13.1-1969 "Guide to Sampling Airborne Radioactive Materials in Nuclear Facilities" (including the guidance presented in Appendix A of ANSIN13.1).

ANSI N13.1-1969. Guide to Sampline Airborne Radioactive Materials in Nuclear Eacillitiex The guidence of this etandard etart in Section 4. Principles. Section 4.1 is General, Section 4.2 is Representative Samples, Section 4.2.1 is Samples Representative According to Spacial Location, Section 4.2.1.1 is Sampling in a Zone Occupies by Workers. The firat ection in this ANSI atandard applicable to the comparieon of this document is 4.2.1.2.

ANSI N13.1-1969. Section 4.2.1.2 Sampling point abould be a minimum of 5 diameters (or 5 times the major dimension for roctangular ducts) downstream from abrupt changes in flow direction or prominent transitions.

Not applicable. 40 CFR 61.93 (b)(2)(i) specifies the site location. See comparison under "Method 1A, Section 2.1.1: Selection of Measurement Site."

ANSI N13.1-1969. Section 4.2.2 Samples should be representative with respect to physical and chemical composition of airetream.

Documentation: WHC-SD-WM-EMP-031, Rev 0

Comparison: No particle size studies have been performed at this facility, though a particle loss determination has been informally (at this time) accomplished. Information provided in WHC-SD-WM-EMP-031, Rev 0 suggest that the sample should consist mainly of ${ }^{137} \mathrm{Cs}$, with small amounts of ${ }^{9} \mathrm{Sr}$. These radionuclides are particulate in nature and are not volatile.

ANSI N13.1-1969. Section 4.3. Sample Programming Many factors enter into the design of a sampling program. The campling program includes the frequency, duration, and volume rate of sampling. In most cases, the eelection of these three elements in programming will be a compromise between idea values and those which provide eafety and are technically, oconomically, and conveniently achieved.

ANSI N13.1-1969. Section 4.3.1 (see Appendix N)

ANSI N13.1-1969. Section 4.3.2 (see Appendix N)

ANSI N13.1-1969. Section 4.3.3 (see Appendix N)

ANSI N13.1-1962. Section 4.3.4 (see Appendix N)

ANSI N13.1-1969. Section 4.3.5 (see Appendix N)

ANSI N13.1-1969, Section 5, Methods 
ANSI N13.1-1969. Section 5.1. General Two forms of airborne radionctive materials are particulate and gases; the particles can be colid or liquid, although particulates are generally considered to be very small fragments of solids. . .

Documentation: WHC-SD-WM-EMP-031, Rev 0

Comparison: Information given in WHC-SD-WM-EMP-031 suggest that the sample should consist mainly of ${ }^{137} \mathrm{Cs}$. This radionuclide is particulate in nature and is not volatile.

\section{ANSIN13.1-1969, Section 5.2. Particles}

ANSI N13.1-1969. Section 5.2.1. Sample Delirery Principles concerning the removal of a ropresentative portion of a contained atream, as from a large duct, have been presented in Section 4. . .

\section{ANSI N13.1-1969. Section 5.2.2. Particle Collectors without Significant Size} Differentiation Various colloctors are applicable to sampling airborne radiaactive matorials. ...

ANSIN13.1-1969. Section 5.2.2.1 (100 Appendix N)

ANSI N13.1-1969. Section 5.2.2.1.7 (100 Appendix N)

ANSLN13.1-1969. Section 5.3. Gases Airborne radioactive volatile materials and co-called "permanent gases auch a tritium are frequently important contaminants and their sampling and collection requires techniques and methods differing from those used in particle sampling.

Documentation: WHC-SD-WM-EMP-031, Rev 0

Comparison: No volatile radionuclides are present at this facility

ANSI N13.1-1969, Section 6.0 (100 Appendix N)

ANSI N13.1-1969. Appendix A. Section A1 Minimization of the length and bends of sample delivery lines will contribute to representative sampling.

Documentation: H-2-73812

Comparison: The sample line is approximately $3.0 \mathrm{~m}(10 \mathrm{ft})$ long. The tubing is 1.9-cm (3/4-in.) O.D. X $0.17 \mathrm{~cm}(0.065$ in.) WALL. There is a single bend radius which is designed to be 10 times the diameter of the tubing.

ANSI N13.1-1969. Appendix A. Section A2 The distance from the last upstream disturbance to the point of sample extraction should be a minimum of 5 and preferably 10 or more duct diameters downstream. Sampling from a vertical run avoids stratification due to gravity settling. Sampling as far downstream as possible avoids most transient variation in airstream quality. 
Not applicable. 40 CFR 61.93 (b)(2)(i) specifies the site location. See comparison under "Method 1A, Section 2.1.1: Selection of Measurement Site."

ANSIN13.1-1969. Appendix A. Section A3.1 Volocity and flow diatribution ahould be known for the eamplins point, and particle and gaseous composition should be representative.

Documentation: Not applicable.

Comparison: Velocity measurements are accomplished by Facilities Maintenance Support Services Preventive Maintenance Procedure 7-GN-56, Rev 2, Airflow Capacity and Distribution Tests in conjunction with supplemental GUIDANCE, 241-SY PRIMARY EXHAUST STACK FLOW MEASUREMENT. From the section above, "Subpart $H$ Section 61.93 (b)(1)(iii)," the average flow rate was observed to be $24,436 \mathrm{~L} / \mathrm{min}\left(863 \mathrm{ft}^{3} / \mathrm{min}\right)$. For an $20-\mathrm{cm}(8$-in.) stack, this

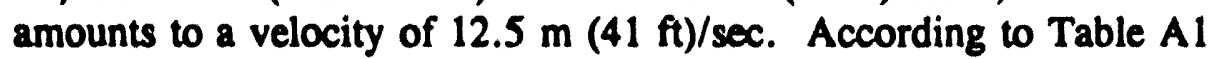
in the ANSI N13.1-1969 Standard laminar flows occur below $.207 \mathrm{~m}$ $(0.68 \mathrm{ft}) / \mathrm{sec}$ ond. Above that turbulent flows exist. The velocity distribution at the sampling site is uniform (see Figures I-1 and I-2), but is based on a limited amount of data. Use the following equation to convert from velocity pressure (inches water, gauge) to velocity (feet per minute).

Velocity $=4005 * \sqrt{\text { VelocityPressure }}$ 
Figure I-1. Stack Flow Distribution 296-P-23-3.

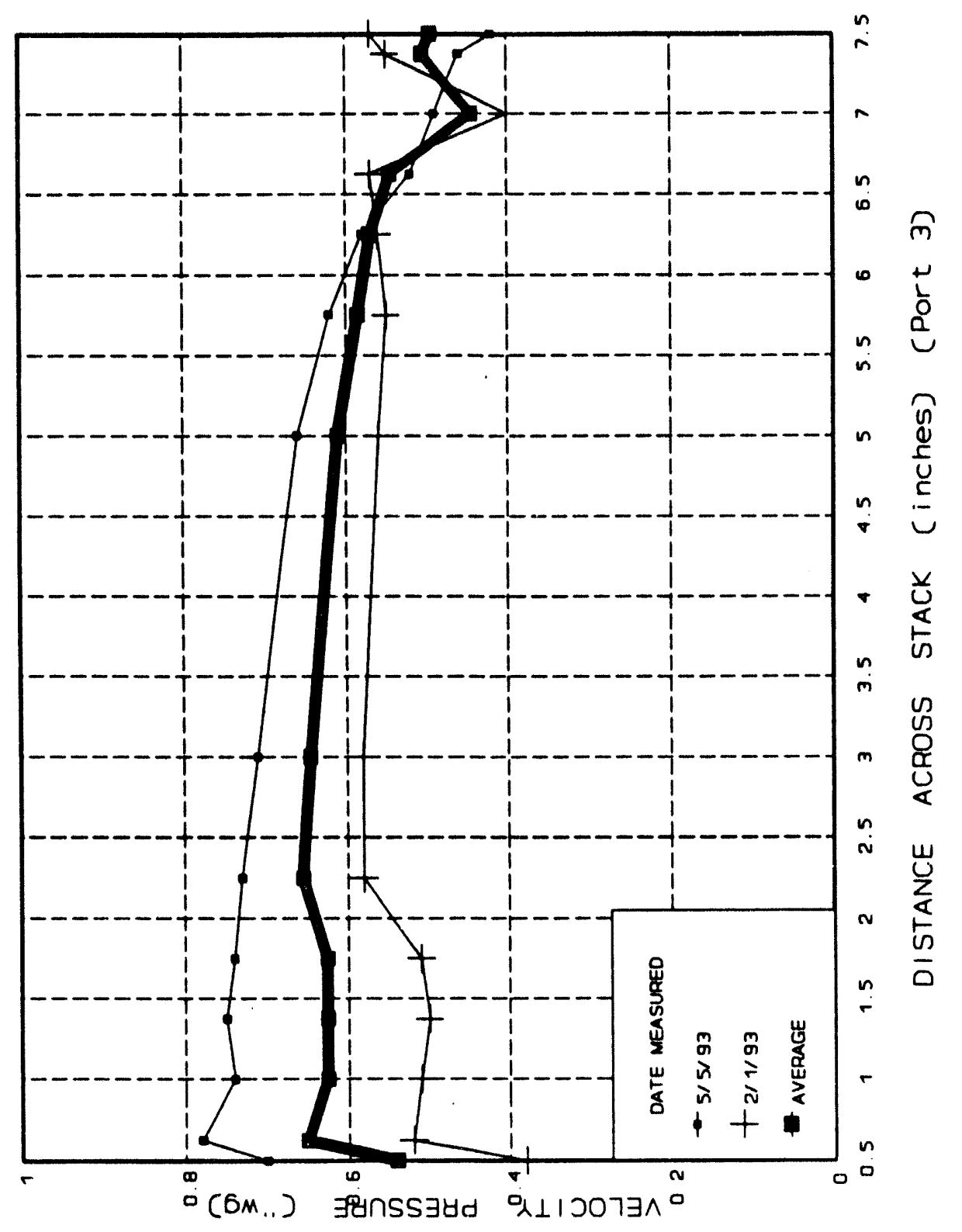


Figure 1-2. Stack Flow Distribution 296-P-23-4.

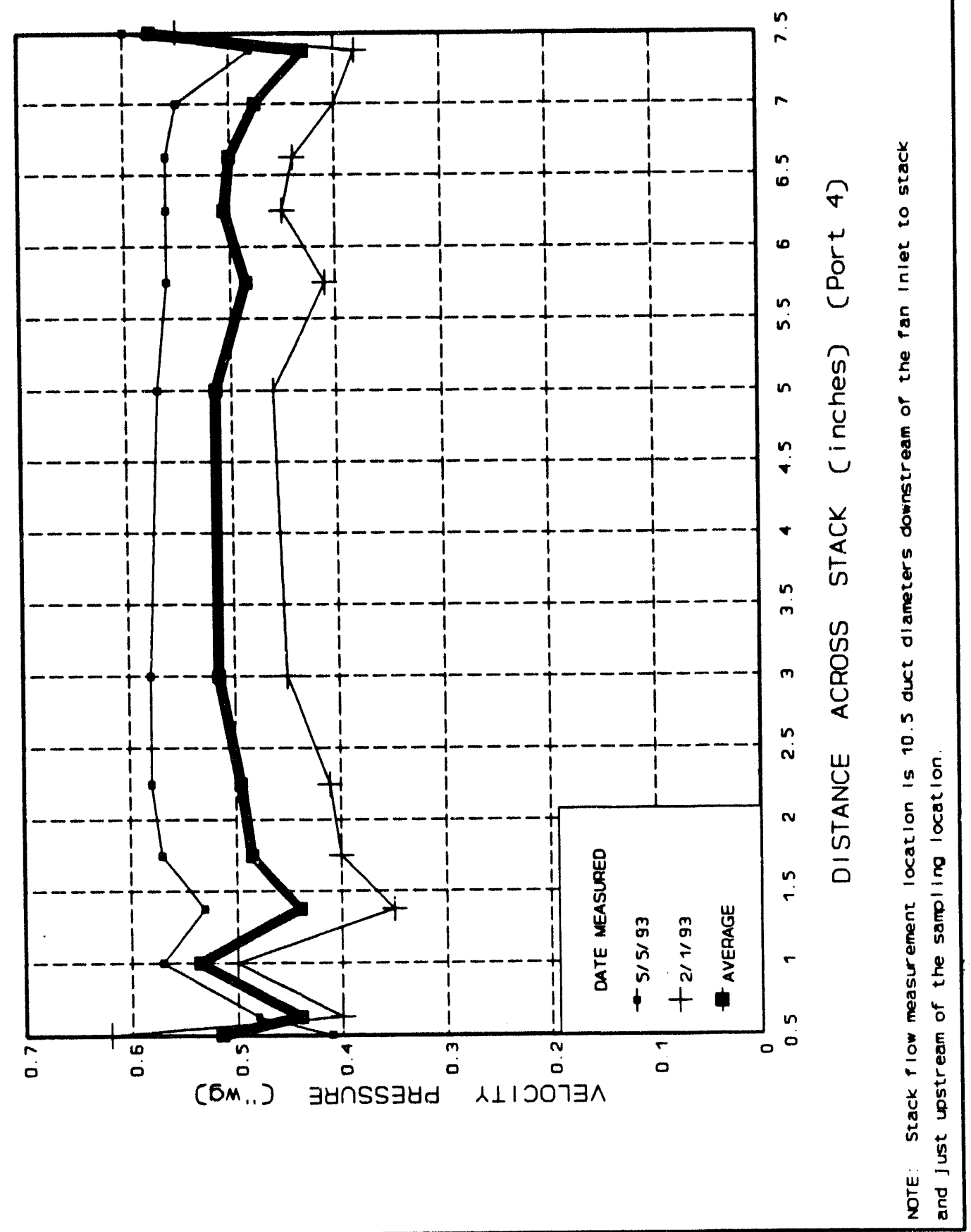


ANSI N13.1-1969. Appendix A. Section A3.2 A multiple number of withdrawal points each representing approximatoly equal areas besed on the duct or atack dimensions is desirable.

Documentation: Drawing H-2-93428

Comparison: This drawing shows the probe with one nozzle. This is as recommended in this section of the ANSI N13.1-1969 Standard, Appendix A, paragraph A3.2 which states "For ducts less than 8 in. in diameter (20 CM) one sample point is adequate; . . ."

ANSI N13.1-1969. Appendix A. Section A3.3 The velocity distribution acroes the duct or atack should bo known in order to eatablish irokinetic flow and reprosentative cample points.

Documentation: Job Control System Work Packages listed under "Subpart H Section 61.93 (b) (1) (iii)"

\section{GUIDANCE, 241-SY PRIMARY EXHAUST STACK FLOW MEASUREMENT}

Facilities Maintenance Support Services Preventive Maintenance Procedure 7-GN-56, Rev 2

\section{Drawing H-2-93427}

Comparison: The velocity distribution is not known. However, uniform distribution may be assumed (see discussion under "ANSI N13.1-1969, Appendix A, Section A3.1" above).

The designed isokinetic flow rate in the stack is $21,548 \mathrm{~L} / \mathrm{min}$ $\left(761 \mathrm{ft}^{3} / \mathrm{min}\right)$, based on a sample flow of $62.3 \mathrm{~L} / \mathrm{min}\left(2.2 \mathrm{ft}^{3} / \mathrm{min}\right)$. Although, it is not reasonable to assume that the design flow is maintained. To determine the true or actual operating condition isokinetic flow rate sample data and instrumentation errors must be accounted for. From 1992 data, the actual sample flow at the sample nozzle openings (taking into account variability in the readings and instrumentation errors) is from 45.3 to $68.0 \mathrm{~L} / \mathrm{min}$ (1.6 to $2.4 \mathrm{ft}^{3} / \mathrm{min}$ ). From this, the actual or operating isokinetic flow rate in the stack is from 15,658 to $23,501 \mathrm{~L} / \mathrm{min}$ (553 to $830 \mathrm{ft}^{3} / \mathrm{min}$ ). Section Subpart H Section 61.93 (b)(1)(iii) above provides the actual flow rates measured in the stack. The average of this data is $24,436 \mathrm{~L} / \mathrm{min}\left(863 \mathrm{ft}^{3} / \mathrm{min}\right)$ with a 95 percent confidence that this flow rate will be between 17,753 to $31,090 \mathrm{~L} / \mathrm{min}(627$ to $1,098 \mathrm{ft}^{3} / \mathrm{min}$ ).

ANSI N13.1-1969. Appendix A. Section A3.4 Sampling probe configuration is recommended by figures in this ANSI Standard, with minimum radius bends and precisely tapered probe end edges. 
Documentation: Drawing H-2-93428

Comparison: This drawing shows the probe as a $1.3 \mathrm{~cm}(1 / 2 \mathrm{in}$.) OD by $0.09 \mathrm{~cm}$ ( 0.035 in.) WALL pipe. This gives an $\mathrm{ID}$ of $1.09 \mathrm{~cm}(0.43 \mathrm{in}$.$) .$

This probe has a bend radius of $5.72 \mathrm{~cm}(2$ and $1 / 4$ in.) and a vertical length below the bend of $12.07 \mathrm{~cm}(4$ and $3 / 4 \mathrm{in}$.).

According to ANSI the bend radius, and the vertical should both be 5 times the inside diameter. Five times the inside diameter of this probe is $5.46 \mathrm{~cm}(2.15 \mathrm{in}$.). In addition the nozzle is tapered to a knife edge.

\section{ANSI N13.1-1969. Appendix B. Particle Deposition in Sample Lines}

Documentation: WHC-SD-WM-ES-291, Rev 1

Comparison: The estimate made for this stack was made using an up-to-date computer software program. The program title is "DEPOSITION 2.0" and is references, as Anand, N. K., McFarland, A.R., Wong, F.S, Kocmound C.J., DEPOSITION 2.0, NRC NuReg/GR-006, Serial \# 2145, March 8, 1993, Aerosol Technology Laboratory, Department of Mechanical Engineering, Texas A\&M University College Station, TX 77843.

Because particle sizes are not known a spread of particle sizes were used (i.e., 10, 3.5 and 1 micron in size). The results are as follows:

STACK NUMBER 296-P-23 SAMPLING SYSTEM PARTICLE PENETRATION PERCENTAGE

\begin{tabular}{|c|c|c|c|c|c|c|c|c|}
\hline & \multicolumn{9}{|c|}{ PARTICLE SIZE } \\
\hline Range & \multicolumn{2}{|c|}{$10 \mu \mathrm{m}$} & \multicolumn{1}{c|}{$\begin{array}{c}\text { PRE-HEPA } \\
\text { SPREAD } \\
(0.05 \text { to } 10 \mu \mathrm{m})\end{array}$} & \multicolumn{2}{c|}{$3.5 \mu \mathrm{m}$} & \multicolumn{2}{|c|}{$1 \mu \mathrm{m}$} \\
\hline & Probe & Total & Probe & Total & Probe & Total & Probe & Total \\
\hline Minimum & 79.9 & 36.1 & 94.2 & 84.8 & 93.3 & 86.6 & 98.0 & 97.4 \\
\hline Average & 97.2 & 52.9 & 98.3 & 89.2 & 97.0 & 90.9 & 98.4 & 97.9 \\
\hline Maximum & 131.2 & 81.0 & 106.8 & 97.1 & 105.0 & 99.4 & 99.3 & 98.8 \\
\hline
\end{tabular}

The variables used in this program are as follows:

Stack diameter 8 in. $=0.2032 \mathrm{~m}$

Area $=\pi R^{2}=0.032429 \mathrm{~m}^{2}$ 
Stack Stream Velocity $(\mathrm{m} / \mathrm{s}): 9.12$ to 15.98

Average: 12.56

Probe Equivalent Radius $=0.215$ in.

Probe Equivalent Diameter $=0.43$ in. $=10.922 \mathrm{~mm}$

Designed Sample Flow Rate $=2.2 \mathrm{ft}^{3} / \mathrm{min}=62.29696 \mathrm{~L} / \mathrm{min}$

Sample Flow rate $(\mathrm{L} / \mathrm{min}): 45.31$ to 67.96

Average: 56.63

Line Length $=10 \mathrm{ft}=3.048 \mathrm{~m}$

Tube ID $=0.62$ in. $=15.748 \mathrm{~mm}$

one 90 degree bend.

ANSI N13.1-1969. Appendix C. Errors Due to Anisokinetic Sampling Evaluated with the software discussed above under ANSI N13.1-1969, Appendix B, Particle Deposition in Sample Lines.

Subpart H Section 61.93 (b) (2) (iii) (20e Appendix N)

Subpart H Section 61.93(b)(2)(iv) (soc Appendix N)

Subpart H Section 61.93(b)(3) (roc Appendix N)

Subpart H Section 61.93(b)(4)(i) (ree Appendix $N$,

Subpart H Section 61.93(b)(4)(ii) (noc Appendix N)

Subpart H Section 61.93(b)(5) (noc Appendix N) 
WHC-EP-0784

\section{APPENDIX J}

40 CFR 61.93, SUBPART H COMPARISON FOR 296-P-28 
This page intentionally left blank. 


\section{PONNT-BY-POINT NESHAP COMPLIANCE COMPARISON FOR THE 241-SY TANK FARM BACKUP EXHAUSTER STACK NUMBER 296-P-28}

\section{Subpart H Section 61.93 (a) (wee Appendix N)}

Subpart H Section 61.93 (b) Radionuclide emiesion rates from point sources (stacks or vents) shall be measured in accordance with the following requirements or procedures for which EPA has granted prior approval:

Subpart H Section 61.93 (b)(1) Effluent flow nte measurements shall be made uaing the following methods:

Subpart H Section 61.93 (b)(1)(i) Reference Method 2 of Appendix A to Part 60 shall be used to determine velocities and volumetric flow rates for atecks and large vents.

\section{Documentation: Drawing H-2-93000}

Comparison: Method 2 is for stacks larger than $30 \mathrm{~cm}$ (12 in.). This stack is smaller than the $30 \mathrm{~cm}$ (12 in.) applicability criteria; it is only $20 \mathrm{~cm}$ (8 in.) Method $2 \mathrm{C}$ is applicable for small stacks. See discussion under Method $2 \mathrm{C}$ below.

Subpart H Section 61.23 (b)(1)(ii) Reference Method 2A of Appendix A to Part 60 shall be used to determine velocities and volumetric flow rates through pipes and amall ducts.

Documentation: Not applicable.

Comparison: Method 2A is not applicable for stacks. If is applicable for pipes and ducts where the entire effluent is run through a measuring device. This method may be applicable to the sampling systems themselves.

40 CFR 60. Appendix A. Method 2C Determination of Stack Gas Velocity and Volumetric Flow Rate in Small Stacks or Ducts: This method allows for the following:

1. Selecting the measurement site per Method 1A in Appendix A of 40 CFR 60

2. Selecting the number of traverwe point measurements per Figure 1-2, "Minimum number of traveree points for velocities (nonparticulate) traverses," in Method 1 in Appendix A of 40 CFR 60

3. Locating the individual traverse measurement points per Table 1-2, "Location of 'Traverse Points in Circular Stacks" of Method 1, of Appendix A of 40 CFR 60.

4. Apparatus

5. Procedure. 
Documentation: Job Control System Work Packages listed under "Subpart H Section 61.93 (b) (1) (iii)"

\section{GUIDANCE, 241-SY PRIMARY BACKUP PORTABLE EXHAUST STACK (296-P-28) FLOW MEASUREMENT}

Facilities Maintenance Support Services Preventive Maintenance Procedure 7-GN-56, Rev 2

\section{Drawing H-2-93000}

Comparison: See the discussion below under "Method 1A, Section 2.1.1: PM Measurement" for selection of the measurement site and requirements. There is one port where this measurements site is located. This site is in the plane of the nozzle opening of the sampler probes. This location is $56 \mathrm{~cm}$ (22 in.) (2.7 duct diameters) below the top of the stack and $97 \mathrm{~cm}$ (38 in.) (4.7 duct diameters) above the fan section of the stack. Figure 1-2 of Method 1 in Appendix A of 40 CFR 60 specifies 16 measurements if the flow disturbances upstream of the site is greater less than 6 duct diameters. However, this figure is mainly for large stacks (though it is referenced for use with small stacks). In a stack that is $20 \mathrm{~cm}$ ( 8 in.) in diameter, an increasing number of measurement points is senseless. Logically, there comes a point when additional data points are no longer useful. Therefore it was decided that measurements would be taken on each of 8 annular traverse points located according to Table 1-2, "Location of Traverse Points in Circular Stacks" of Method 1, of Appendix A of 40 CFR 60. There is only one port at this location, so only one set of traverse points can be taken.

A standard pitot tube is used as specified. However, the procedure is not duplicated. A new procedure is under development which will duplicate the regulatory procedure.

Subpart H Section 61.93 (b)(1)(iii) The frequency of flow rate measurements shall depend upon the variability of the effluent flow rate. For variable flow rates, continuous or frequent flow rates measurements shall be made. For relatively constant flow rates, only periodic measurements are necessary. 
Documentation: The following flows were obtained from this facility. Note, where available, the Job Control System Work Package number and date the measurement was taken is given below:
DATE
ELOW $\left(\mathrm{ft}^{2} / \mathrm{min}\right)$
WP Number

$02 / 28 / 91$

$05 / 06 / 91$

$08 / 05 / 91$

$10 / 27 / 92$

$05 / 28 / 93$

AVERAGE

VARIABILITY

STANDARD DEVIATION

95\% CONFIDENT INTERVAL RANGE
682

665

793

603

783

$2 \mathrm{~W} \quad 25017$

2W-91-00401

2W-91-00859

2W-92-00964

2W-93-00312

705

$-14 \% /+11 \%$

81

225

480 to 930.

Comparison: Although the regulations do not specifically define variable versus constants flow rate, a flow rate with a variability of less than \pm 20 percent has been defined at the Hanford Site as being continuous. This criteria is specified in SD-WM-CR-016. The flow rates given above are therefore constant. The schedule for taking these flows is quarterly. Although the quarterly schedule is not always met, the requirement at the Hanford Site is to take flow rates at least annually when the exhauster is running. This exhauster does not always run.

Subpart H Section 61.93 (b)(2) Radionuclides shall be directly monitored or extracted, collected and measured using the following methods:

Subpart H Section 61.93 (b)(2)(i) Reference Method 1 of Appendix A Part 60 shall be used to select monitoring or sampling sites.

40 CFR 60. Appendix A. Method 1 Sample and Velocity Traverses for Stationary Sources.

40 CFR 60. Appendix A. Method 1. Section 1.2: Applicability This method is applicable to flowing gas atreams in ducts, stacks, and flues. This method cannot be used when (1) flow is cyclonic or swirling (see section 2.4); (2) a stack is smaller than about $0.30 \mathrm{~m}$ (12 in.) in diameter, or $0.071 \mathrm{~m}^{2}$ (113 in..$\left.^{2}\right)$ cross-sectional area; or (3) the measurement site is less than two stack or duct diameters downstream or less than a half diameter upstream from a flow disturbance.

Documentation: Drawing H-2-93000 
Comparison: This stack is smaller than the 30-cm (12-in.) applicability criteria; it is only $20 \mathrm{~cm}(8 \mathrm{in}$.$) . See Method 1 \mathrm{~A}$ below.

\begin{abstract}
40 CER 60. Appendix A. Method 1. Section 2.1: Selection of Measurement Site Sampling or velocity meanurement is performod at a site located at leant oight atack or duct diameters downatream and two diameters upatream from any disturbances auch as a bend, oxpansion, or contraction in the atrack, or from a visible flame. If noceseary, an alternative location may be selocted, at a position at least two atack or duct diameters downstream and a half diameter upstroam from any flow disturbance.
\end{abstract}

Not applicable. This stack is smaller than the 30-cm (12-in.) applicability criteria; it is only $20.32 \mathrm{~cm}(8 \mathrm{in}$.$) .$

40 CFR 60. Appendix A. Method $1 A$ Sample and Volocity Traverees for Stationary Sources with Small Stecks or Ducts This method is applicable to stacks or ducts less than about $0.30 \mathrm{~m}$ (12 in.) is diameter, or $0.071 \mathrm{~m}^{2}\left(113 \mathrm{in}^{2}\right)$ crose-ecctional area, but equal to or greater than about $0.10 \mathrm{~m}\left(4 \mathrm{in}\right.$.) in diameter or $0.00812 \mathrm{~m}^{2}\left(12.57 \mathrm{in}^{2}\right)$ in crose-ectional area.

40 CFR 60. Appendix A. Method 1A. Section 2.1.1: PM Measurement Method $1 \mathrm{~A}$ calls for the eampling sites to be preferably located at least 8 equivalent stack or duct diameters downstream and 10 equivalent diameters upstream from any flow disturbances. The velocity measurement location is recommended to be at a site located 8 equivalent stack or duct diameters downstream of the sampling site. This method further stipulates that if ouch locations are not available, then the eampling site should be located at least 2 equivalent stack or duct diameters downstream and $2 \frac{1}{2}$ atack diameters upstream from any flow disturbances. The velocity measurement device should then be located 2 equivalent stack diameters downstream from the sampling site.

Documentation: Job Control System Work Packages listed under "Subpart H Section 61.93 (b) (1) (iii)"

\title{
GUIDANCE, 241-SY PRIMARY BACKUP PORTABLE
} EXHAUST STACK (296-P-28) FLOW MEASUREMENT

Facilities Maintenance Support Services Preventive Maintenance Procedure 7-GN-56, Rev 2

Drawings $\mathrm{H}-2-93000$ and $\mathrm{H}-2-93001$

Comparison: The center line of the sampling probe is located $43 \mathrm{~cm} \mathrm{(17} \mathrm{in.)}$ below the top of the stack. The nozzle opening is $13 \mathrm{~cm}(5 \mathrm{in}$. below this or $56 \mathrm{~cm}(22 \mathrm{in}$.) ( 2.7 duct diameters) below the top of the stack. This location is $97 \mathrm{~cm}(38 \mathrm{in}$.$) ( 4.7$ duct diameters) above the fan section of the stack.

Subpart H Section 61.93 (b) (2) (ii) The effluent stream shall be directly monitored continuously with an in-line detector or representative samples of the effluent stream shall be withdrawn continuously from the sampling site following the guidance presented in ANSI N13.1-1969 "Guide to Sampling Airborne Radioactive Materials in Nuclear Facilities" (including the guidance presented in Appendix A of ANSIN13.1). 
ANSI N13.1-1969. Guide to Sampline Airborne Radioactive Materials in Nuclear Eacillities The guidance of this standard ant in Section 4. Principles. Section 4.1 is General, Section 4.2 is Representative Samples, Section 4.2.1 is Samples Representative According to Spacial Location, Section 4.2.1.1 is Sampling in a Zone Occupied by Workers. The first ection in this ANSI etandard applicable to the comparieon of this document is 4.2.1.2.

ANSI N13.1-1969. Section 4.2.1.2 Sampling point ahould be a minimum of 5 diameters (or 5 times the major dimonsion for rectangular ducts) downetream from abrupt changes in flow direction or prominent transitions.

Not applicable. 40 CFR 61.93 (b)(2)(i) specifies the site location. See comparison under "Method 1A, Section 2.1.1: Selection of Measurement Site."

ANSI N13.1-1969. Section 4.2.2 Samples ahould be representative with respect to physical and chemical componition of airatream.

Documentation: WHC-SD-WM-EMP-031, Rev 0

Comparison: No particle size studies have been performed at this facility, although a particle loss determination has been informally (at this time) accomplished. Information given in WHC-SD-WM-EMP-031, Rev 0 suggest that the sample should consist mainly of ${ }^{137} \mathrm{Cs}$, with small amounts of ${ }^{20} \mathrm{Sr}$. These radionuclides are particulate in nature and are not volatile.

ANSI N13.1-1969. Section 4.3. Sample Programming Many factors onter into the design of a sampling program. The eampling program includes the frequency, duration, and volume rate of sampling. In most cases the selection of these three elements in programming will be a compromise between idea values and those which provide safety and yet are technically, oconomically, and conveniently achieved.

ANSI N13.1-1969. Section 4.3.1 (see Appendix N)

ANSI N13.1-1969. Section 4.3.2 (200 Appendix N)

ANSI N13.1-1969. Section 4.3.3 (100 Appendix N)

ANSI N13.1-1969. Section 4.3.4 (see Appendix N)

ANSI N13.1-1969. Section 4.3.5 (see Appendix N)

\section{ANSI N13.1-1969, Section 5. Methods}

ANSI N13.1-1969. Section 5.1. General Two forms of airborne radioactive materials are particulate and gases; the particles can be solid or liquid, although particulates are generally considered to be very small fragments of solids. . .

Documentation: WHC-SD-WM-EMP-031, Rev 0 
Comparison: Information provided in WHC-SD-WM-EMP-031 suggests that the sample should consist mainly of ${ }^{137} \mathrm{Cs}$. This radionuclide is particulate in nature and is not volatile.

\section{ANSIN13.1-1969. Section 5.2. Particles}

ANSIN13.1-1969. Section 5.2.1. Sample Delivery Principles concerning the removal of a representative portion of a contained stream, a from a large duct, have been precented in Section 4. .

ANSI N13.1-1969. Section 5.2.2. Particle Collectors without Significant Size Differentiation Various collectors are applicable to sampling airborne radioactive materials. . .

ANSIN13.1-1969. Section 5.2.2.1 (coe Appendix N)

ANSI N13.1-1969. Section 5.2.2.1.7 (coe Appendix N)

ANSI N13.1-1969. Section 5.3. Gases Airborne radionctive volatile materials and so-called "permanent gaees auch a tritium are frequently important contaminante and their campling and collection requires tochniques and methods differing from those used in particle sampling. . .

Documentation: WHC-SD-WM-EMP-031, Rev 0

Comparison: No volatile radionuclides are present at this facility

ANSI N13.1-1969. Section 6.0 (100 Appendix N)

ANSI N13.1-1969. Appendix A. Section A1 Minimization of the length and bends of sample delivery lines will contribute to representative sampling.

Documentation: H-2-93001

Comparison: The sample line is approximately $51 \mathrm{~cm}$ (20 in.) long from the probe connection outside the stack to the sample cabinet. The tubing is $1.3 \mathrm{~cm}(1 / 2$ in.) O.D. X $0.17 \mathrm{~cm}(0.065$ in.) WALL. There are no bends, the sample tube is horizontal from the stack to the cabinet.

ANSI N13.1-1969. Appendix A. Section A2 The distance from the last upstream disturbance to the point of cample extraction ahould be a minimum of five and preferably ten or more duct diameters downstream. Sampling from a vertical run avoids stratification due to gravity settling. Sampling as far downstream as possible avoids most transient variation in airstream quality.

Not applicable. 40 CFR 61.93 (b)(2)(i) specifies the site location. See comparison under "Method 1A, Section 2.1.1: Selection of Measurement Site."

ANSI N13.1-1969. Appendix A. Section A3.1 Velocity and flow distribution should be known for the sampling point, and particle and gaseous composition should be representative. 
Documentation: None

Comparison: Velocity measurements are accomplished by Facilities Maintenance Support Services Preventive Maintenance Procedure 7-GN-56, Rev 2, Airflow Capacity and Distribution Tests in conjunction with supplemental GUIDANCE, 241-SY PRIMARY BACKUP PORTABLE EXHAUST STACK (296-P-28) FLOW MEASUREMENT. From the section above, "Subpart $H$ Section 61.93 (b)(1)(iii)," the average flow rate was seen to be $19,962 \mathrm{~L} / \mathrm{min}\left(705 \mathrm{ft}^{3} / \mathrm{min}\right)$. For an $20-\mathrm{cm}(8-\mathrm{in}$.) stack, this amounts to a velocity of about $10 \mathrm{~m}(33 \mathrm{ft}) /$ second. According to Table A1 in the ANSI N13.1-1969 Standard laminar flows occur below $.2 \mathrm{~m}(0.68 \mathrm{ft}) /$ second. Above that turbulent flows exist. Figure J-1 is a plot of the velocity distribution, which is based on a very limited amount of data. Use the following equation to convert from velocity pressure (inches water, gauge) to velocity (feet per minute).

Velocity $=4005 * \sqrt{\text { VelocityPressure }}$ 
Figure J-1. Stack Flow Distribution 296-P-28-A.

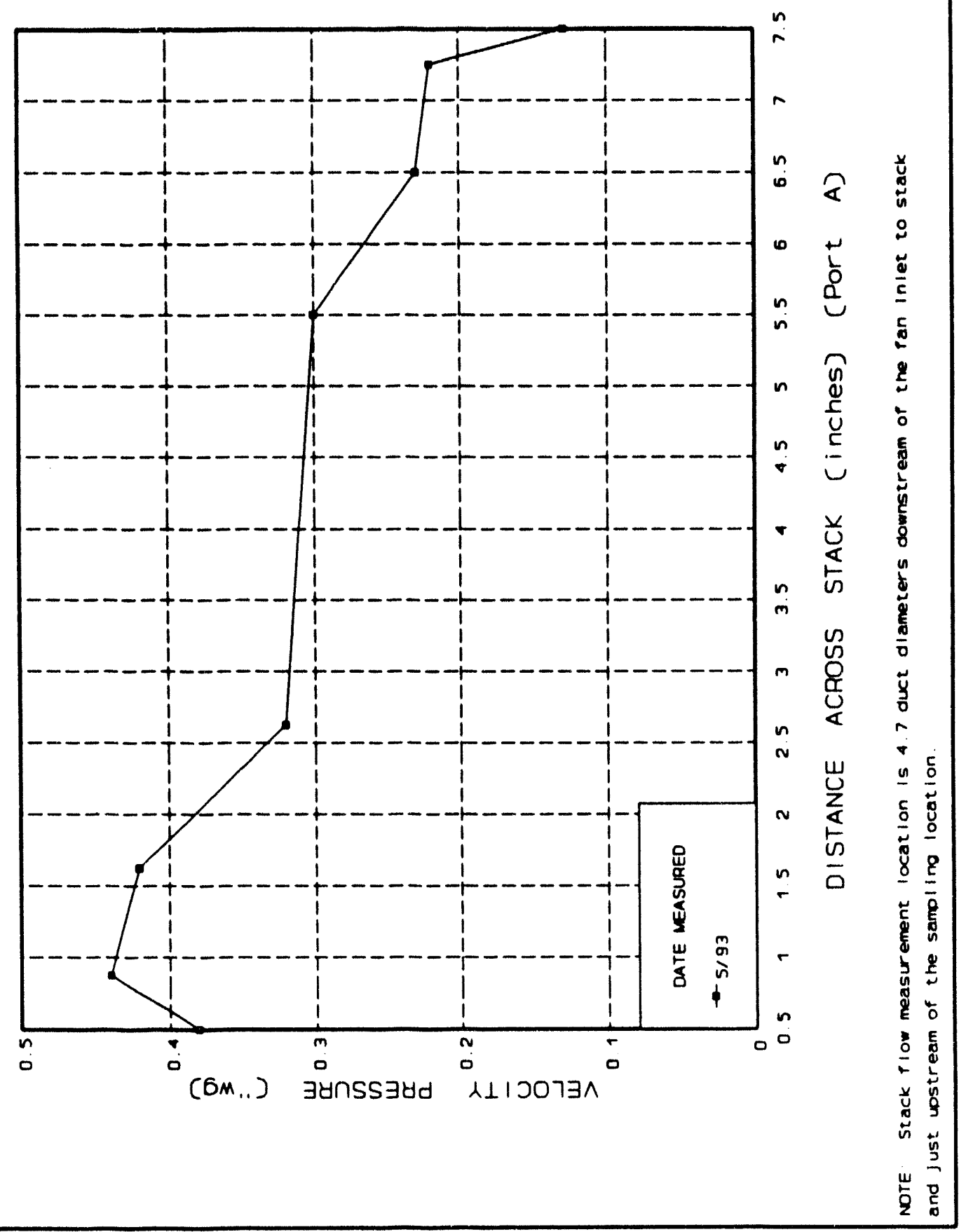


ANSI N13.1-1969. Appendix A. Section A3.2 A multiple number of withdrawal points each representing approximatoly oqual areas besed on the duct or atack dimensions is desirable.

Documentation: Drawing H-2-93001

Comparison: This drawing shows the probe with two nozzles that are joined outside the stack. This is as recommended in this section of the ANSI N13.1-1969 Standard, Appendix A.

ANSI N13.1-1969. Appendix A.Section A3.3 The volocity dietribution acroes the duct or stack ahould be known in order to eatabliah isokinetic flow and represontative cample points.

Documentation: Job Control System Work Packages listed under "Subpart H Section 61.93 (b) (1) (iii)"

GUIDANCE, 241-SY PRIMARY BACKUP PORTABLE EXHAUST STACK (296-P-28) FLOW MEASUREMENT

Facilities Maintenance Support Services Preventive Maintenance Procedure 7-GN-56, Rev 2

Drawing H-2-93001

Comparison: The designed isokinetic flow rate in the stack is $25,993 \mathrm{~L} / \mathrm{min}$ $\left(918 \mathrm{ft}^{3} / \mathrm{min}\right)$, based on a sample flow of $62.3 \mathrm{~L} / \mathrm{min}\left(2.2 \mathrm{ft}^{3} / \mathrm{min}\right)$. Although, it is not reasonable to assume that the design flow is maintained. To determine the true or actual operating condition isokinetic flow rate sample data and instrumentation errors must be accounted for. Data, 1992, shows that the actual sample flow at the sample nozzle openings (taking into account variability in the readings and instrumentation errors) is from 36.8 to $76.4 \mathrm{~L} / \mathrm{min}(1.3$ to $\left.2.7 \mathrm{ft}^{3} / \mathrm{min}\right)$. From this, the actual or operating isokinetic flow rate in the stack is from 15,347 to $31,911 \mathrm{~cm}(542$ to $1,127 \mathrm{ft}^{3} / \mathrm{min}$ ). Section Subpart H Section 61.93 (b)(1)(iii) above gives the actual flow rates measured in the stack. The average of this data is $19,962 \mathrm{~L} / \mathrm{min}\left(705 \mathrm{ft}^{3} / \mathrm{min}\right)$ with a 95 percent confidence that this flow rate will be between 13,591 to $26,333 \mathrm{~L} / \mathrm{min}(480$ and $930 \mathrm{ft}^{3} / \mathrm{min}$ ).

ANSI N13.1-1969. Appendix A. Section A3.4 Sampling probe configuration is recommended by figures in this ANSI Standard, with minimum radius bends and precisely tapered probe ond edges. 


\section{Documentation: Drawing H-2-93001}

Comparison: This drawing shows the probe with a $.71 \mathrm{~cm}(9 / 32 \mathrm{in}$.) nozzle piece attached to a $1 / 2$ OD by 0.065 WALL pipe. This shows the nozzle opening with an $\mathrm{ID}$ of $.71 \mathrm{~cm}(0.28125 \mathrm{in}$.$) and a tube or pipe \mathrm{ID}$ of $.94 \mathrm{~cm}(0.37 \mathrm{in}$.$) . This probe has a bend radius of 6.4 \mathrm{~cm}(2.5 \mathrm{in}$. and a vertical length below the bend of $7.95 \mathrm{~cm}(3.13 \mathrm{in}$.$) .$ According to ANSI the bend radius, as well as the vertical section should both be 5 times the inside diameter. Five times the inside diameter of the probe nozzle is $4.70 \mathrm{~cm}(1.85 \mathrm{in}$.). Five times the inside diameter of the tube is $3.6 \mathrm{~cm}(1.4 \mathrm{in}$.). In addition, the nozzle tips are tapered to knife edges.

\section{ANSI N13.1-1969. Appendix B. Particle Deposition in Sample Lines}

\section{Documentation: WHC-SD-WM-ES-291, Rev 1}

Comparison: The estimate for this stack was made using an up-to-date computer software program. The program title is "DEPOSITION 2.0" and is referenced as N. K. Anand, A. R. McFarland, F. S. Wong, C. J. Kocmound, DEPOSITION 2.0, NRC NuReg/GR-006, Serial \# 2145, March 8, 1993, Aerosol Technology Laboratory, Department of Mechanical Engineering, Texas A\&M University College Station, TX 77843.

Because particle sizes are not known a spread of particle sizes were used (i.e., 10, 3.5 and 1 micron in size). The results are as follows:

Table C24. Stack Number 296-P-28 Sampling System Particle Penetration Percentage.

\begin{tabular}{|c|c|c|c|c|c|c|}
\hline & \multicolumn{4}{c|}{ Particle Size } \\
\hline Range & \multicolumn{2}{|c|}{$10 \mu \mathrm{m}$} & \multicolumn{2}{c|}{$3.5 \mu \mathrm{m}$} & \multicolumn{2}{c|}{$1 \mu \mathrm{m}$} \\
\hline & Probe & Total & Probe & Total & Probe & Total \\
\hline Minimum & 71.0 & 17.7 & 91.3 & 83.9 & 97.7 & 97.6 \\
\hline Average & 81.6 & 29.4 & 93.5 & 90.8 & 98.0 & 97.9 \\
\hline Maximum & 117.5 & 65.5 & 101.6 & 100.9 & 99.0 & 98.9 \\
\hline
\end{tabular}

The variables used in this program are as follows:

Stack diameter 8.125 in $=0.206375 \mathrm{~m}$

Area $=\pi R^{2}=0.03345 \mathrm{~m}^{2}$ 
Stack Stream Velocity $(\mathrm{m} / \mathrm{s}): 6.77$ to 13.12

Average: 9.95

Probe Equivalent Radius $=0.19888$ in

Probe Equivalent Diameter $=0.3977617$ in $=10.103 \mathrm{~mm}$

Designed Sample Flow Rate $=2.2 \mathrm{ft} / \mathrm{min}=62.29696 \mathrm{~L} / \mathrm{min}$

Sample Flow rate $(\mathrm{L} / \mathrm{min}): 36.81$ to 76.46

Average: 56.63

Line Length $=1.7 \mathrm{ft}=0.508 \mathrm{~m}$ Tube ID $=0.37$ in. $=9.398 \mathrm{~mm}$ no bends

ANSI N13.1-1969. Appendix C. Erroes Due to Anisokinetic Sampling Evaluated with the software discussed above under ANSI N13.1-1969, Appendix B, Particle Deposition in Sample Lines.

Subpart H Section 61.93 (b) (2) (iii) (see Appendix N)

Subpart H Section 61.93(b)(2)(iv) (sec Appendix N)

Subpart H Section 61.93(b)(3) (see Appendix N)

Subpart H Section 61.93(b)(4)(i) (sec Appendix N)

Subpart H Section 61.93(b)(4)(ii) (sec Appendix N)

Subpart H Section 61.93(b)(5) (soe Appendix N) 
This page intentionally left blank. 


\section{APPENDIX K}

40 CFR 61.93, SUBPART H COMPARISON FOR 296-S-15 
This page intentionally left blank. 


\section{PONNT-BY-POINT NESHAP COMPLIANCE COMPARISON FOR THE 241-SX TANK FARM EXHAUSTER STACK NUMBER 296-S-15}

Subpart H Section 61.93 (a) (coe Appendix N)

Subpart H Section 61.93 (b) Radionuclide emission rates from point wources (etacks or vents) shall be measured in accordance with the following requirements or procedures for which EPA has granted prior approval:

Subpart H Section 61.93 (b)(1) Efluent flow rate measurements shall be made using the following methods:

Subpart H Section 61.93 (b)(1)(i) Reference Method 2 of Appendix A to Part 60 shall be used to determine velocities and volumetric flow rates for atacks and hrge vents.

40 CFR 60. Appendix A. Method 2 Determination of Stack Gas Velocity and Volumetric Flow Rate (Type S Pitot Tube) Method 2 is applicable for measurement of the average velocity of a gas stream and for quantifying gas flow. This procedure is not applicable for:

- Cyclonic or awirling gas atreame

- Stack diameters smaller than $0.30 \mathrm{~m}$ (12 in.) or stack cross sectional areas less than $0.071 \mathrm{~m}^{2}$ (113in')

- Measurement sites which fail to meet the criteria of Method 1 in 40 CFR 60, Appendix A, 8.1)

Documentation: Maintenance Engineering Services Maintenance Procedure 1202, Rev 0

WHC-SD-WM-WP-147, Rev 1

Comparison: The referenced procedure has been written to mirror the 40 CFR 60 , Appendix A, Method 2 procedure. Implementation of this procedure is addressed in the referenced procedure upgrade program.

Implementation involves writing facility specific procedures from the main referenced procedure. The specific procedure development is underway. The measurement site selection requirement is addressed next.

\section{CER 60. Appendix A. Method 1. \& 2.1. Selection of Measurement Site} Sampling or velocity measurement is performed at a site located at least 8 stack or duct diameters downstream and 2 diameters upstream from any disturbances auch as a bend, expansion, or contraction in the stack, or from a visible flame. If necessary, an alternative location may be selected, at a position at least two stack or duct diameters downstream and less than a half diameter upstream from a flow disturbance. 
Documentation: Drawings H-2-35834 and H-2-35835

Job Control System Work Packages listed under "Subpart H Section 61.93 (b) (1) (iii)"

\section{GUIDANCE/DATA SHEET FOR 241-SX EXHAUST STACK (296-S-15) FLOW MEASUREMENT}

Facilities Maintenance Support Services Preventive Maintenance Procedure 7-GN-56, Rev 2

Comparison: This is a $1.07-\mathrm{m}$ (42 in.) circular diameter stack approximately

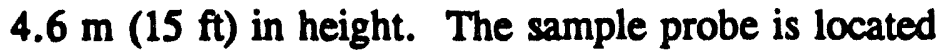
approximately $1.37 \mathrm{~m}$ (54 in.) below the top of the stack and $81 \mathrm{~cm}$ ( 32 in.) above the fan discharge into the stack. There are two ports 90 degrees apart approximately six inches below the sample probe [ $66 \mathrm{~cm}$ (26 in.) above the fan discharge]. Because there are not enough stack diameters to acquire a good flow measurement on the stack from the two ports just described, a location along the duct work before the fan was chosen to acquire these measurements.

There were three 61-cm (24-in.) diameter, circular ducts leading into the stack, before the fans. One of these ducts is disconnected and sealed. The location chosen to acquire flow measurements are on the two active ducts is as follows:

Flow measurements are taken on the northern most duct from a single port which is $99 \mathrm{~cm}$ (29 in.) upstream from the flow disturbance presented by the structure containing the HEPA filters for that duct and approximately $3.4 \mathrm{~m} \mathrm{(11} \mathrm{ft)}$ downstream from the flow disturbance caused by the plenum containing the heaters.

Flow measurements are taken on the southern most duct from a single port which is $99 \mathrm{~cm}$ (39 in.) upstream from the flow disturbance presented by a bend in the duct before the fans.

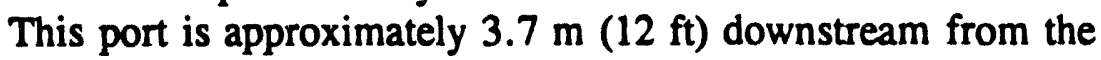
flow disturbance presented by the structure which houses the HEPA filters for that duct.

In both these ports, 16 annular traverse measurements are taken. Each traverse point is located according to Table 1-2, "Location of Traverse Points in Circular Stacks" of Method 1, of Appendix A of 40 CFR 60. 
Subpart H Section 61.93 (b)(1)(ii) Reference Method 2A of Appendix A to Part 60 shall be used to determine velocities and volumetric flow ntes through pipes and amall ducts.

Documentation: None.

Comparison: Method 2A is not applicable for stacks. It is applicable for pipes and ducts where the entire effluent is run through a measuring device. This method may be applicable to the sampling systems themselves.

Subpart H Section 61.93 (b)(1)(iii) The frequency of flow rate measurements shall depend on the variability of the effluent flow rate. For variable bow rates, continuous or froquent flow rates measurements shall be made. For relatively constant flow rates, only periodic measurements are nocessary.

Documentation: The following flows were obtained from this facility. Note, where available the Job Control System Work Package number and date the measurement was taken is given:

\section{DATE ELOW $\left(\mathrm{ft}^{3} / \mathrm{min}\right) \quad$ WP\#}

$\begin{array}{lll}09 / 18 / 90 & 4,753 & \text { NONE } \\ 12 / 11 / 90 & 5,040 & \text { NONE } \\ 02 / 28 / 91 & 5,404 & 2 W-90-02056 \\ 03 / 20 / 91 & 5,539 & \text { NONE } \\ 06 / 18 / 91 & 3,962 & 2 W-91-00542 \\ 09 / 09 / 91 & 2,167 & 2 W-91-01086 \\ 09 / 30 / 92 & 3,671 & 2 W-92-00894 \\ 03 / 17 / 93 & 4,323 & 2 W-92-01358 \\ 05 / 06 / 93 & 3,766 & 2 W-93-00314 \\ 06 / 10 / 93 & 3,490 & 2 W-93-00421\end{array}$

AVERAGE $\quad 4,212$

VARIABILITY $-49 \% /+32 \%$

STANDARD DEVIATION 1,024

95\% CONFIDENCE INTERVAL 2,315

RANGE $\quad 1,896$ to 6,527

Comparison: Although the regulations do not specifically define variable versus constants flow rate, a flow rate with a variability of less than \pm 20 percent has been defined at the Hanford Site as being continuous. This criteria is specified in SD-WM-CR-016. The flow rates given above are therefore, variable. The schedule for taking these flows is quarterly. Although the quarterly schedule is not always met, the requirement at the Hanford Site is to take flow rates at least annually when the exhauster is running. This exhauster runs continuously except for maintenance. 
Subpart H Section 61.93 (b)(2) Radionuclides shall be directly monitored or extracted, collected and measured using the following methods:

Subpart H Section 61.93 (b)(2)(i) Reference Mathod 1 of Appendix A Part 60 shall be used to select monitoring or eumpling sites.

40 CFR 60. Appendix A. Method 1 Sample and Velocity Traveres for Stationary Sources.

40 CFR 60. Appendix A. Method 1. Section 1.2: Applicability This method is applicable to flowing sas streams in ducts, atacks, and flues. This method cannot be used when (1) flow is cyclonic or awirling (cee Section 2.4); (2) a atack is amaller than about $0.30 \mathrm{~m}$ (12 in.) in diameter, or 0.071 $\mathrm{m}^{2}$ (113 in. $\left.{ }^{2}\right)$ crose-sectional area; or (3) the meanurement site is less than two stack or duct diameters downstream or less than a half diameter upatream from a flow disturbance.

Documentation: Drawing H-2-35835

Comparison: This stack is $\mathbf{4 2}$ in. in diameter and therefore this method is applicable.

\section{CFR 60. Appendix A. Method 1. Section 2.1: Selection of Measurement Site} Sampling or velocity mearurement is performed at a site located at least 8 stack or duct diameters downtream and 2 diametere upstream from any dieturbances auch as a bend, expansion, or contraction in the stack, or from a visible flame. If neceseary, an alternative location may be selected, at a position at least two stack or duct diameters downstream and a half diameter upstream from any flow disturbance.

\section{Documentation: Drawing H-2-35835}

Comparison: Also see comparison under 40 CFR 60, Appendix A, Method 1, \$ 2.1, Selection of Measurement Site, under 40 CFR 60, Appendix A, Method 2," Determination of Stack Gas Velocity and Volumetric Flow Rate (Type S Pitot Tube) above. This is a $1.07 \mathrm{~m}$

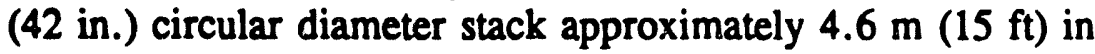
height. The sample probe is located approximately 1.3 duct diameters below the top of the stack and only 0.8 duct diameters above the fan discharge into the stack.

Subpart H Section 61.93 (b) (2) (ii) The effluent stream shall be directly monitored continuously with an in-line detector or representative samples of the effluent stream shall be withdrawn continuously from the sampling site following the guidance presented in ANSI N13.1-1969 "Guide to Sampling Airborne Radioactive Materials in Nuclear Facilities" (including the guidance preaented in Appendix A of ANSIN13.1).

\footnotetext{
ANSI N13.1-1969. Guide to Sampline Airborne Radioactive Materials in Nuclear Facilities The guidance for this standard begins in Section 4. Principles. Section 4.1 is General, Section 4.2 is Representative Samples, Section 4.2.1 is Samples Representative According to Spacial Location, Section 4.2.1.1 is Sampling in a Zone Occupies by Workers. The first section in this ANSI standard applicable to the comparison of this document is 4.2.1.2.
} 
ANSI N13.1-1969, Section 4,2.1.2. Sampline from a Duct or Exhaust Stack Sampling point ahould be a minimum of 5 dinmetere (or 5 times the major dimension for rectangular ducts) downatream from abrupt changes in flow direction or prominent transitions.

Not applicable. 40 CFR 61.93 (b)(2)(i) specifies the site location. See comparison under "Method 1, Section 2.1: Selection of Measurement Site."

\begin{abstract}
ANSL N13.1-1969. Section 4.2.2. Samples Representative with Respect to Physical and Chemical Composition Those subections (4.2.2.1, 4.2.2.2, 4.2.2.3, and 4.2.2.4) discuss losees in general. These coctions touch on chemical composition of the atream being ampled, particle size, probe location, delivery lines, collection filters, and refors to Appendixas B and C of the atandard.
\end{abstract}

Documentation: WHC-SD-WM-ES-291, Rev 1

$$
\text { WHC-SD-WM-EMP-031, Rev } 0
$$

Comparison: Particle size studies have not been performed at this facility. Particle loss determination has been accomplished however (refer to WHC-SD-WM-ES-291). See comparison under ANSI N13.1-1969, Appendix B below.

Information given in WHC-SD-WM-EMP-031 suggest that the sample should consist mainly of ${ }^{89190} \mathrm{Sr},{ }^{137} \mathrm{Cs}$, and ${ }^{241} \mathrm{Am}$. These radionuclides are particulate in nature and are not volatile.

ANSI N13.1-1969. Section 4.3. Sample Programming Many factors enter into the design of a campling program. The sampling program includes the frequency, duration, and volume rate of eampling. In moat casos, the selection of these throe elements in programming will be a compromice between ideal values and those which provide eafety and are technically, economically, and conveniently achieved.

ANSI N13.1-1969. Section 4.3.1 (100 Appendix N)

ANSI N13.1-1969. Section 4.3.2 (100 Appendix N)

ANSI N13.1-1969. Section 4.3.3 (100 Appendix N)

ANSI N13.1-1969, Section 4.3.4 (100 Appendix N)

ANSI N13.1-1969. Section 4.3.5 (see Appendix N)

\title{
ANSI N13.1-1969, Section 5. Methods
}

ANSI N13.1-1969. Section 5.1. General Two forms of airborne radioactive materials are particulate and gases; the particles can be solid or liquid, although particulates are generally considered to be small fragments of solids. . .

Documentation: WHC-SD-WM-EMP-031, Rev 0 
Comparison: Information given in WHC-SD-WM-EMP-031 suggest that the sample should consist mainly of ${ }^{89 / 50} \mathrm{Sr},{ }^{137} \mathrm{Cs}$, and ${ }^{211} \mathrm{Am}$. These radionuclides are particulate in nature and are not volatile.

\section{ANSI N13.1-1969. Section 5.2. Particles}

ANSI N13.1-1969. Section 5.2.1. Sample Dellivery Principles concerning the removal of a representative portion of a contained atream, a from a large duct, have been presented in Section 4. . .

ANSI N13.1-1969. Section 5.2.2. Particle Collectors without Sienificant Size Differentiation Various colloctors are applicable to sampling airborne radioactive materials. . .

ANSI N13.1-1969. Section 5.2.2.1 (c00 Appondix N)

ANSL N13.1-1969. Section 5.2.2.1.7 (co Appondix N)

ANSI N13.1-1969. Section 5.3. Gases Airborne radionctive volatile materials and eo-called "pormanent gases wch a tritium are frequently important contaminants and their sampling and collection requires tochniques and mothode differing from thowe used in particle sampling.

Documentation: WHC-SD-WM-EMP-031, Rev 0

Comparison: No volatile radionuclides are present at this facility.

\section{ANSIN13.1-1969. Section 6.0 (coe Appendix N)}

ANSI N13.1-1969. Appendix A. Section A1 Minimization of the length and bends of ample delivery lines will contribute to representative sampling.

Documentation: Drawing H-2-74913

Comparison: The sample line is approximately $2.4 \mathrm{~m}(8 \mathrm{ft})$ long from the probe connection outside the stack to the top of the sample cabinet. There are two bends less than 90 degree designed to have a minimum bend radius of 10 times the tube diameter. The tubing is $1.9 \mathrm{~cm}(3 / 4 \mathrm{in}$.) O.D. X $0.17 \mathrm{~cm}(0.065 \mathrm{in}$.) WALL. This makes the inside diameter $1.57 \mathrm{~cm}(0.62 \mathrm{in}$.$) .$

ANSI N13.1-1969. Appendix A. Section A2 The distance from the last upstream disturbance to the point of sample extraction ahould be a minimum of 5 and preferably 10 or more duct diameters downstream. Sampling from a vertical run avoids atratification due to gravity settling. Sampling as far downstream as possible avoids most transient variation in airstream quality.

Not applicable. 40 CFR 61.93 (b)(2)(i) specifies the site location. See comparison under "Method 1, Section 2.1: Selection of Measurement Site." 
ANSI N13.1-1969. Appendix A. Section A3.1 Volocity and flow dietribution ahould bo known for the ampling point, and particlo and ancous composition chould be representative.

Documentation: Not applicable.

Comparison: Velocity measurements are accomplished by Facilities Maintenance Support Services Preventive Maintenance Procedure 7-GN-56, Rev 2, Airflow Capacity and Distribution Tests in conjunction with supplemental GUIDANCE/DATA SHEET FOR 241-SX EXHAUST STACK (296-S-15) FLOW MEASUREMENT. From the section above, "Subpart H Section 61.93 (b)(1)(iii)," the average flow rate was seen to be $119,262 \mathrm{~L} / \mathrm{min}(4,212 \mathrm{ft} / \mathrm{min})$. For a $42 \mathrm{in}$. stack, this amounts to a velocity of $2.23 \mathrm{~m}(7.30 \mathrm{ft}) / \mathrm{sec}$. Table A1 in the ANSI N13.1-1969 Standard laminar flows occur

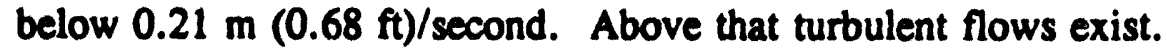
According to ANSI N13.1-1969 Section A3.3.2 "as the flow becomes more turbulent, the velocity becomes more nearly uniform across the duct." However, significant duct diameters do not exist for the flow profile to be uniform according to Method 1 (see comparison discussion under "Method 1, Section 2.1: Selection of Measurement Site").

ANSI N13.1-1969. Appendix A. Section A3.2 A multiple number of withdrawal points each representing approximatoly oqual areas besed on the duct or ateck dimensions is desirable.

Documentation: Drawing H-2-95250

Comparison: This drawing shows the probe with five nozzles. Each nozzle is located approximately in the center of each of 5 equal annular areas. This is as recommended in this section of the ANSI N13.1-1969 Standard for this size stack [107 cm (42 in.)].

ANSI N13.1-1969. Appendix A. Section A3.3 The velocity distribution across the duct or stack should be known in order to astablish isokinetic flow and representative cample points.

Decumentation: Not applicable.

Comparison: The velocity distribution is not known.

The designed isokinetic flow rate in the stack is $135,996 \mathrm{~L} / \mathrm{min}$ $\left(4,803 \mathrm{ft}^{3} / \mathrm{min}\right)$, based on a sample flow of $62.3 \mathrm{~L} / \mathrm{min}\left(2.2 \mathrm{ft}^{3} / \mathrm{min}\right)$. Although, it is not reasonable to assume that the design flow is maintained. To determine the true or actual operating condition isokinetic flow rate sample data and instrumentation errors must be accounted for. From 1992 data, the actual sample flow at the sample nozzle openings (taking into account variability in the readings and 
instrumentation errors) is from 42.5 to $65.1 \mathrm{~L} / \mathrm{min}$ (1.5 to $2.3 \mathrm{ft} / \mathrm{min})$. From this, the actual or operating isokinetic flow rate in the stack is from 92,731 to $142,169 \mathrm{~L} / \mathrm{min}(3,275$ to $5,021 \mathrm{ft}^{3} / \mathrm{min}$ ). Section Subpart H Section 61.93 (b)(1)(iii) above gives the actual flow rates measured in the stack. The average of this data is $119,262 \mathrm{~L} / \mathrm{min}\left(4,212 \mathrm{ft}^{3} / \mathrm{min}\right)$ with a 95 percent confidence interval that the flow rate will be between 53,685 to $184,811 \mathrm{~L} / \min \left(1,896\right.$ to $\left.6,527 \mathrm{ft}^{3} / \mathrm{min}\right)$.

ANSI N13.1-1969. Appendix A. Section A3.4 Sampling probe configuration is recommended by figures in this ANSI Standard, with minimum radius bends and precicely tapered probe end edges.

\section{Documentation: Drawing H-2-95250}

Comparison: This drawing provides the probe nozzles as $1.3 \mathrm{~cm}(1 / 2 \mathrm{in.})$ OD by $0.12 \mathrm{~cm}(0.049 \mathrm{in}$.) WALL. This gives the ID as $1.021 \mathrm{~cm}$ (0.402 in.). In addition, each nozzle has a $5.72 \mathrm{~cm}$ (2 and 1/4 in.) bend radius and is approximately $2.5 \mathrm{~cm}$ ( 1 in.) in length under bend radius. According to ANSI the bend radius, and the vertical should both be 5 times the inside diameter. Five times the inside diameter of this probe is $5.11 \mathrm{~cm}(2.01 \mathrm{in}$.). In addition the nozzle is tapered to a knife edge.

\section{ANSI N13.1-1969. Appendix B. Particle Deposition in Sample Lines}

\section{Documentation: WHC-SD-WM-ES-291, Rev 1}

Comparison: The estimate made for this stack was made using an up-to-date computer software program. The program title is "DEPOSITION 2.0" and is references as Anand, N. K., McFarland, A.R., Wong, F.S, Kocmound C.J., DEPOSITION 2.0, NRC NuReg/GR-006, Serial \# 2145, March 8, 1993, Aerosol Technology Laboratory, Department of Mechanical Engineering, Texas A\&M University College Station, TX 77843. This program also provides for anisokinetic sampling affects as discussed in ANSI N13.1-1969, Appendix C.

Since particle sizes are not know a spread of particle sizes were used 10, 3.5 and 1 micron in size. The results are as follows: 
STACK NUMBER 296-S-15 SAMPLING SYSTEM PARTICLE PENETRATION PERCENTAGE

\begin{tabular}{|c|c|c|c|c|c|c|}
\hline & \multicolumn{5}{|c|}{ PARTICLE SIZE } \\
\hline Range & \multicolumn{2}{|c|}{$10 \mu \mathrm{m}$} & \multicolumn{2}{c|}{$3.5 \mu \mathrm{m}$} & \multicolumn{2}{c|}{$1 \mu \mathrm{m}$} \\
\hline & Probe & Total & Probe & Total & Probe & Total \\
\hline Minimum & 96.5 & 48.6 & 99.0 & 92.3 & 99.7 & 99.1 \\
\hline Average & 99.0 & 57.8 & 99.6 & 93.7 & 99.8 & 99.3 \\
\hline Maximum & 108.3 & 70.1 & 101.0 & 95.9 & 100.0 & 99.5 \\
\hline
\end{tabular}

The variables use in this program are as follows:

Stack diameter 42 in. $=1.0668 \mathrm{~m}$

Area $=\pi R^{2}=0.8938 \mathrm{~m}^{2}$

Stack Stream Velocity $(\mathrm{m} / \mathrm{s}): 1.00$ to 3.47

Average: 2.22

Probe Equivalent Radius $=0.449449664$ in.

Probe Equivalent Diameter $=0.898899327$ in. $=22.83204291 \mathrm{~mm}$

Designed Sample Flow Rate $=2.2 \mathrm{ft}^{3} / \mathrm{min}=62.29696 \mathrm{~L} / \mathrm{min}$

Sample Flow rate $(\mathrm{L} / \mathrm{min}): 42.48$ to 65.13

Average: 53.80

Line Length $=8 \mathrm{ft}=2.4384 \mathrm{~m}$

Tube ID $=0.62 \mathrm{in} .=15.748 \mathrm{~mm}$

two $45^{\circ}$ bend

ANSI N13,1-1969, Appendix C. Errors Due to Anisokinetic Sampling Evaluated with the software discussed above under ANSI N13.1-1969, Appendix B, Particle Deposition in Sample Lines.

Subpart H Section 61.93 (b) (2) (iii) (see Appendix N)

Subpart H Section 61.93(b)(2)(iv) (sec Appendix N)

Subpart H Section 61.93(b)(3) (see Appendix N) 


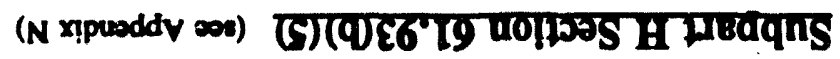

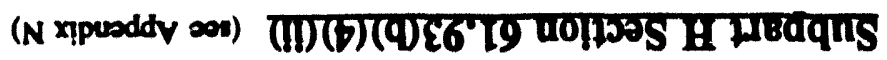

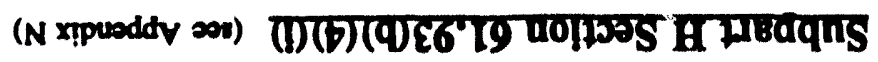


APPENDIX L

40 CFR 61.93, SUBPART H COMPARISON FOR 296-S-22

L-1 
This page intentionally left blank. 


\section{POINT-BY-POINT NESHAP COMPLIANCE COMPARISON FOR THE 244S DOUBLE CONTANED RECEIVER TANK EXHAUSTER STACK NUMBER 296-S-22}

\section{Subpart H Section 61.23 (a) (ree Appendix N)}

Subpart H Section 61.93 (b) Radionuclide emistion rates from point sources (stacks or vents) shall be measured in accordance with the following requirements or procedures for which EPA has granted prisor approval:

Subpart H. Section 61.93 (b)(1) Effluent flow rate measurements shall be made using the following methods:

Subpart H Section 61.93 (b)(1)(i) Reference Method 2 of Appendix A to Part 60 shall be used to determine velocities and volumetric flow rates for etacks and large vents.

\section{Documentation: Drawing H-2-71048}

Comparison: $\quad$ Method 2 is for stacks larger than $30 \mathrm{~cm}$ (12 in.). This stack is smaller than the $30 \mathrm{~cm}$ (12 in.) applicability criteria; it is only $15 \mathrm{~cm}(6 \mathrm{in}$.$) .$ Method $2 \mathrm{C}$ is applicable for small stacks. See discussion under Method $2 \mathrm{C}$ below.

Subpart H Section 61.93 (b)(1)(ii) Reference Method $2 A$ of Appendix A to Part 60 shall be used to determine velocities and volumetric flow rates through pipes and small ducts.

Documentation: Not applicable.

Comparison: Method 2A is not applicable for stacks. It is applicable for pipes and ducts where the entire effluent is run through a measuring device. This method may be applicable to the sampling systems themselves.

40 CFR 60. Appendix A. Reference 2C Determination of Stack Gas Velocity and Volumetric Flow Rate in Small Stacks or Ducts: This method allows for the following:

1. The celection of the measurement site according to Method 1A in Appendix A of 40 CFR 60 .

2. The selection of the number of traverse point measurements per Figure 1-2, "Minimum number of traverse points for velocities (nonparticulate) traverses, " in Method 1 in Appendix A of 40 CFR 60.

3. The location of the individual traverse measurement points according to Table 1-2, "Location of Traverce Points in Circular Stacks" of Method 1, of Appendix A of 40 CFR 60.
4. Apparatus
5. Procedure. 
Decumentation: Job Control System Work Packages listed under "Subpart H Section 61.93 (b) (1) (iii)"

\section{GUIDANCE/DATA SHEET FOR 244-S DCRT EXHAUST STACK (296-S-22) FLOW MEASUREMENT}

\section{Facilities Maintenance Support Services Preventive Maintenance} Procedure 7-GN-56, Rev 2

Comparison: See the discussion below under "Method 1A, Section 2.1.1: PM Measurement" for selection of the measurement site and requirements. The measurement site is 5 duct diameter under the nozzle opening of the record sampler probe and 4.75 duct diameters above the fan discharge to the stack. Figure 1-2 of Method 1 in Appendix A of 40 CFR 60 specifies 16 measurements if the flow disturbances upstream of the site is less than 6 duct diameters. However, this figure is mainly for large stacks (although it is referenced for use with small stacks). In a stack that is $15 \mathrm{~cm}$ (6 in.) in diameter, an increasing number of measurement points begins to get senseless. Logically, there comes a point when additional data points are no longer useful. Therefore it was decided that measurements would be taken on each of 8 annular traverse points located according to Table 1-2, "Location of Traverse Points in Circular Stacks" of Method 1, of Appendix A of 40 CFR 60. Only one port is at this location, so only one set of traverse points can be taken.

A standard pitot tube is used as specified. However, the procedure is not duplicated. A new procedure is under development that will duplicate the regulatory procedure.

Subpart H Section 61.93 (b)(1)(iii) The froquency of flow rate measurements shall depend upon the variability of the effluent How rate. For variable now rates, continuous or frequent flow rates measurements shall be made. For relatively constant flow rates only periodic measurements are necesary.

Documentation: The following flows were obtained from this facility. Note, where available the Job Control System Work Package number and date the measurement was taken is given: 


$\begin{array}{ccl}\text { DATE } & \text { ELOW }\left(\mathrm{ft}^{3} / \mathrm{min}\right) & \text { WP NO } \\ 09 / 18 / 90 & 122 & \text { NONE } \\ 05 / 11 / 93 & 174 & 2 W-92-00963\end{array}$

AVERAGE $\quad 148$

VARIABILITY $-18 \% /+18 \%$

STANDARD DEVIATION 37

95\% CONFIDENCE INTERVAL 467

RANGE Not enough data points to establish.

Comparison: Although the regulations do not specifically define variable versus constant flow rate, a flow rate with a variability of less than \pm 20 percent has been defined at the Hanford Site as being continuous. This criteria is specified in SD-WM-CR-016. The flow rates given above are constant with the little data available. The schedule for taking these flows is quarterly. Although the quarterly schedule is not always met, the requirement at the Hanford Site is to take flow rates at least annually when the exhauster is running. This exhauster does not always run. Its purpose is to run when the temperature of the waste in the tank is above $60^{\circ} \mathrm{C}\left(140^{\circ} \mathrm{F}\right)$ and/or while waste is being transferred through this facility.

Subpart H Section 61.93 (b)(2) Radionuclides shall be directly monitorod or extracted, collected, and measured using the following methods:

Subpart H Section 61.93 (b)(2)(i) Reference Method 1 of Appendix A Part 60 shall be used to select monitoring or ampling sites.

40 CFR 60. Appendix A. Method 1 Sample and Velocity Traverses for Stationary Sources.

40 CFR 60. Appendix A. Method 1. Section 1.2: Applicability This method is applicable to flowing gas ctreams in ducts, stacks, and flues. This method cannot be used when (1) flow is cyclonic or swirling (coe cection 2.4); (2) a stack is smaller than about $0.30 \mathrm{~m}$ (12 in.) in diameter, or 0.071 $\mathrm{m}^{2}$ (113 in. $\left.{ }^{2}\right)$ cross-ectional area; or (3) the measurement site is less than two stack or duct diameters downstream or less than a half diameter upstream from a flow disturbance.

Documentation: Drawing H-2-71048

Comparison: This stack is smaller than the 30-cm (12-in.) applicability criteria; it is only $15 \mathrm{~cm}$ (6 in.). See Method 1A below.

40 CFR 60. Appendix A. Method 1. Section 2.1: Selection of Measurement Site Sampling or velocity measurement is performed at a site located at least 8 stack or duct diameters downstream and 2 diameter upstream from any disturbances such as a bend, expansion, or contraction in the stack, or from a visible flame. If neceseary, an alternative location may be selected, at a position at least two stack or duct diameters downstream and a half diameter upstream from any flow disturbance. 
Not applicable. This stack is smaller than the $30-\mathrm{cm}$ (12-in.) applicability criteria; it is only $15 \mathrm{~cm}(6 \mathrm{in}$.$) .$

40 CER 60. Appendix A. Method 1 A Sample and Velocity Traverees for Stationary Sources with Small Stacks or Ducts This method is applicable to atacks or ducts less than about 0.30 $m\left(12\right.$ in.) in diamoter, or $0.071 \mathrm{~m}^{2}\left(113 \mathrm{in}^{2}\right)$ crow-wetional area, but equal to or greater than about $0.10 \mathrm{~m} \mathrm{(4} \mathrm{in.)} \mathrm{in} \mathrm{diameter} \mathrm{or} 0.00812 \mathrm{~m}^{2}\left(12.57 \mathrm{in} .^{3}\right)$ in crow-ectional area.

\title{
40 CER 60. Appendix A. Method 1A. Section 2.1.1: PM Measurement
} Method 1A calls for the eampling sites to be preferably located at leat 8 equivalent atack or duct diametere downatream and 10 equivalent diameters upatream from any flow diaturbances. The velocity mearurement location is recommended to be at a site located 8 equivalent stack or duct diameters downetream of the enmpling site. This method further atipulates that if auch locations are not available, then the ampling site chould be located at least 2 equivalent atack or duct diamoters downatroam and $21 / 2$ atack diameters upatream from any flow diaturbances. The velocity meanurement device should then be located 2 equivalent stack diameters downstream from the sampling site.

Documentation: Drawing H-2-71048

\section{GUIDANCE/DATA SHEET FOR 244-TX DCRT EXHAUST STACK (296-T-18) FLOW MEASUREMENT}

\author{
Facilities Maintenance Support Services Preventive \\ Maintenance Procedure 7-GN-56, Rev 2
}

Comparison: This stack is smaller than the 30-cm (12-in.) applicability criteria; it is only $15 \mathrm{~cm}$ (6 in.).

This stack is $15 \mathrm{~cm}$ (6 in.) in diameter. The sample probe location is located $5 \mathrm{ft}$ above the fan discharge into the stack. The closest flow disturbances are:

Downstream the nozzle opening of the sample probe is 2 duct diameters below the nozzle opening of the CAM sample probe.

Upstream the fan discharge into the stack is 9.75 duct diameters below the sample probe.

Flow measurements are accomplished via Facilities Maintenance Support Services Preventive Maintenance Procedure 7-GN-56, Rev 2. One port is chosen for the measurement. The port is 5 duct diameter under the nozzle opening of the record sampler probe and 4.75 duct diameters above the fan discharge to the stack. Although 
this location is not downstream of the sample probe, it is considered to be a conservative location for measurement purposes for two reasons:

1. Three sample probes are on this stack. Two are for continuous monitors and one is for the record sampler. Each probe draws a sample at a rate of approximately $57 \mathrm{~L} / \mathrm{min}\left(2 \mathrm{ft}^{3} / \mathrm{min}\right)$ of air flow from the stack to total $170 \mathrm{~L} / \mathrm{min}\left(6 \mathrm{ft}^{3} / \mathrm{min}\right)$. This sample flow taken from the average stack flow given above of $4191 \mathrm{~L} / \mathrm{min}$ (148 $\left.\mathrm{ft}^{3} / \mathrm{min}\right)$, will result in $4021 \mathrm{~L} / \mathrm{min}\left(142 \mathrm{ft}^{3} / \mathrm{min}\right)$ downstream of all three sample probes. Although $6 \mathrm{ft}^{3} /$ min only represents 4 percent of the average stack flow, a more conservative representation of the actual totalized flow can be gained from the measurement occurring below the sample probes. Totalized flow is necessary for total emission calculations.

2. Because the probes are removing air from the stack stream, the location of the flow measurement below the sample probes give a truer representation of the flow rate for the first sample probe (the record sampler). This allows for a truer representation of the isokinetic flow conditions that are used to determine the efficiency of the system.

Measurements are taken on each of 8 annular traverse points located according to Table 1-2, "Location of Traverse Points in Circular Stacks" of Method 1, of Appendix A to this same regulation.

Subpart H Section 61.93 (b) (2) (ii) The effluent stream shall be directly monitored continuously with an in-line detector or representative samples of the effluent atream shall be withdrawn continuously from the sampling site following the guidance presented in ANSI N13.1-1969, "Guide to Sampling Airborne Radioactive Materials in Nuclear Facilities" (including the guidance presented in Appendix A of ANSIN13.1).

\section{ANSI N13.1-1969. Guide to Sampling Airborne Radioactive Materials in Nuclear} Facilities The guidance for this atandard atarts in Section 4. Principles. Section 4.1 is General, Section 4.2 is Representative Samples, Section 4.2.1 is Samples Representative According to Spacial Location, Section 4.2.1.1 is Sampling in a Zone Occupies by Workers. The first section in this ANSI standard applicable to the comparison of this document is 4.2.1.2.

ANSI N13,1-1969. Section 4,2.1.2 Sampling point should be a minimum of 5 diameters (or 5 times the major dimension for rectangular ducts) downstream from abrupt changes in flow direction or prominent transitions. 
Not applicable. 40 CFR 61.93 (b)(2)(i) specifies the site location. See comparison under "Method 1A, Section 2.1.1: Selection of Measurement Site."

ANSI N13.1-1969. Section 4.2.2 Samples thould be representative with respect to physical and chemical composition of airtream.

Documentation: WHC-SD-WM-EMP-031, Rev 0

Comparison: No particle size studies have been performed at this facility, although a particle loss determination has been informally (at this time) accomplished. Information given in WHC-SD-WM-EMP-031, Rev 0 , suggests that the sample should consist mainly of ${ }^{89 / 90} \mathrm{Sr}$, ${ }^{137} \mathrm{Cs}$, ${ }^{239120} \mathrm{Pu}$, and ${ }^{241} \mathrm{Am}$. These radionuclides are particulate in nature and are not volatile.

ANSI N13.1-1969, Section 4.3. Sample Programming Many factors enter into the design of a campling program. The campling program includes the frequency, duration, and volume rate of ampling. In moat cases the celection of these three elements in programming will be a compromice between idea values and thoee which provide eafety and are technically, economically, and conveniently achieved.

ANSI N13.1-1969. Section 4.3.1 (200 Appendix N)

ANSI N13.1-1969. Section 4.3.2 (we Appendix N)

ANSI N13.1-1969. Section 4.3.3 (see Appendix N)

ANSI N13.1-1969, Section 4.3.4 (20e Appendix N)

ANSI N13.1-1969. Section 4.3.5 (200 Appendix N)

ANSI N13.1-1969. Section 5. Methods

ANSI N13.1-1969. Section 5.1. General Two forms of airborne radioactive materials are particulate and gases; the particles can be solid or liquid, although particulates are generally considered to be very small fragments of colids. ..

Documentation: WHC-SD-WM-EMP-031, Rev 0

Comparison: Information given in WHC-SD-WM-EMP-031 suggest that the sample should consist mainly of ${ }^{89190} \mathrm{Sr},{ }^{137} \mathrm{Cs},{ }^{2391240} \mathrm{Pu}$, and ${ }^{241} \mathrm{Am}$. These radionuclides are particulate in nature and are not volatile.

\section{ANSI N13.1-1969. Section 5.2. Particles}

ANSI N13.1-1969. Section 5.2.1. Sample Delivery Principles concerning the removal of a representative portion of a contained stream, as from a large duct, have been presented in Section 4. . . 


\section{ANSI N13.1-1969. Section 5.2.2. Particle Collectors without Significant Size Differentiation Various colloctors aro applicable to sampling airborne radioactive materials. . .}

\section{ANSI N13.1-1969, Section 5.2.2.1 (400 Appendix N)}

\section{ANSIN13.1-1969. Section 5.2.2.1.7 (200 Appendix N)}

ANSI N13.1-1969. Section 5.3. Gases Airborbe radionctive volatile materials and wo-called "permanent gases such as tritium are frequently important contaminants and their sampling and collection requires toshniques and methods differing from those used in particle sampling.

Documentation: WHC-SD-WM-EMP-031, Rev 0

Comparison: No volatile radionuclides are present at this facility.

\section{ANSI N13.1-1969. Section 6.0 (200 Appendix N)}

ANSI N13.1-1969. Appendix A. Section A1 Minimization of the length and bends of sample delivery lines will contribute to representative sampling.

Documentation: Drawing H-2-46785 and field walkdown

Comparison: The sample line is approximately $.46 \mathrm{~m}(1.5 \mathrm{ft})$ long with a single 90 degree bend. The tube is $1.3 \mathrm{~cm}(1 / 2 \mathrm{in}$.) OD by $0.09 \mathrm{~cm}$ (0.035 in.) wall.

ANSI N13.1-1969. Appendix A. Section A2 The distance from the last upstream disturbance to the point of ample extraction should be a minimum of 5 and preferably 10 or more duct diameters downstream. Sampling from a vertical run avoids stratification due to gravity settling. Sampling as far downstream as possible avoids most transient variation in airstream quality.

Not applicable. 40 CFR 61.93 (b)(2)(i) specifies the site location. See comparison under "Method 1A, Section 2.1.1: Selection of Measurement Site."

ANSI N13.1-1969. Appendix A. Section A3.1 Velocity and flow distribution should be known for the sampling point, and particle and gaseous composition should be representative. 
Comparison: Velocity measurements are accomplished by Facilities Maintenance Support Services Preventive Maintenance Procedure 7-GN-56, Rev 2 in conjunction with supplemental GUIDANCE/DATA SHEET FOR 244-TX DCRT EXHAUST STACK (296-T-18) FLOW MEASUREMENT. From the section above, "Subpart $H$ Section 61.93 (b)(1)(iii)," the average flow rate was seen to be 4191 $\mathrm{L} / \mathrm{min}\left(148 \mathrm{ft}^{3} / \mathrm{min}\right)$. For a $15 \mathrm{~cm}(6 \mathrm{in}$.) stack, this amounts to a

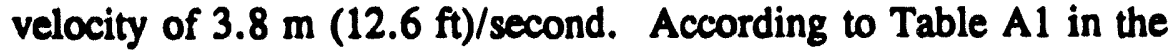
ANSI N13.1-1969 Standard laminar flows occur below $.207 \mathrm{~m}$ $(0.68 \mathrm{ft}) / \mathrm{sec}$ nd. Above that turbulent flows exist. Figure L-3 shows the velocity distribution for this stack. Note that this distribution is based on a very limited amount of data. Use the following equation to convert from velocity pressure (inches water, gauge) to velocity (feet per minute).

Velocity $=4005 * \sqrt{\text { VelocityPressure }}$ 
Figure L-1. Stack Flow Distribution 296-S-22-A.

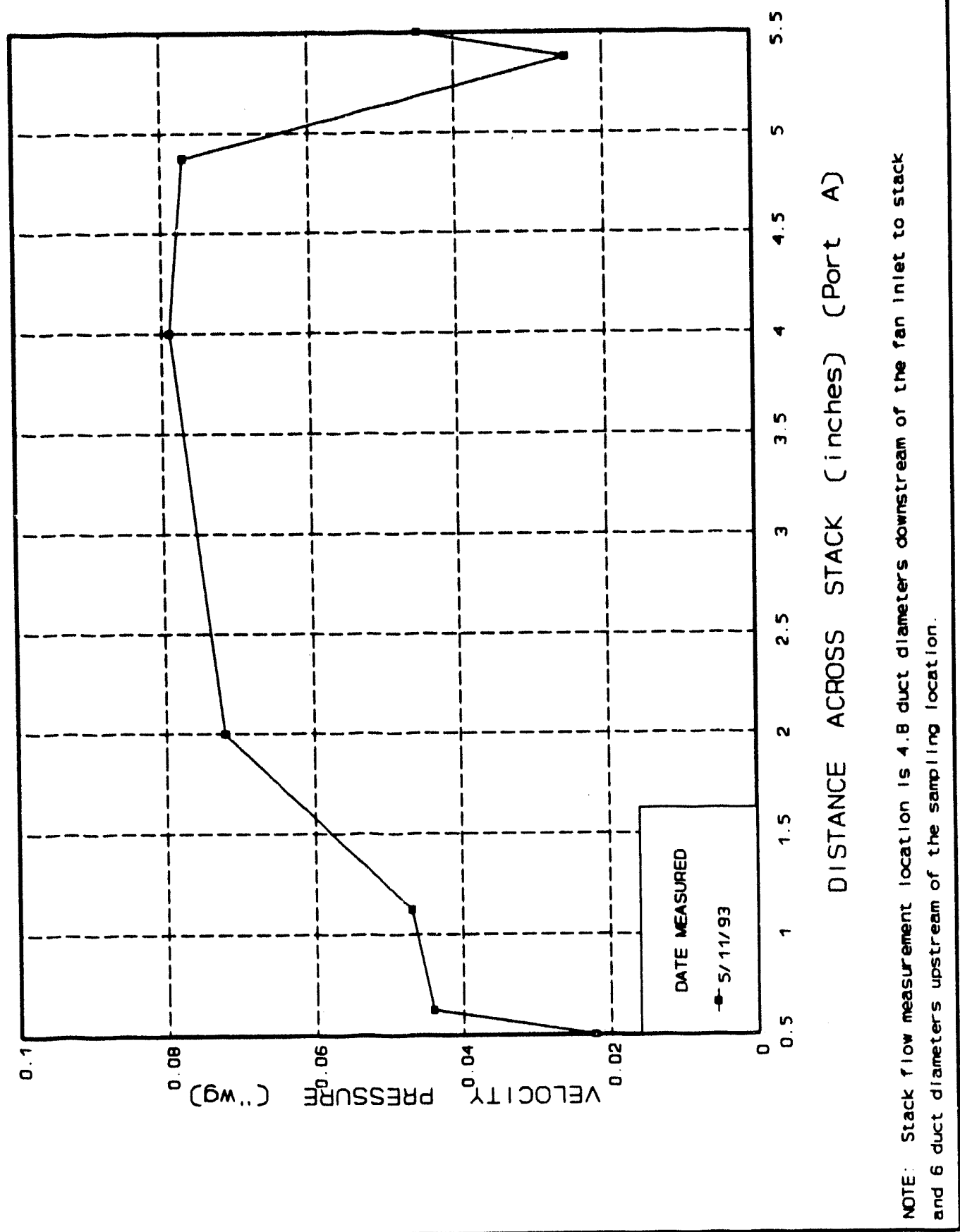


ANSI N13.1-1969. Appendix A. Segtion A3.2 A multiple number of withdrawal points each reprecenting approximntoly equal aress based on the duct or atek dimennions is desirable.

Documentation: Drawing H-2-46785

Comparison: This drawing shows the probe with one nozzle. This is as recommended in this section of the ANSI N13.1-1969 Standard for this size stack $15 \mathrm{~cm}$ (6 in.).

ANSIN13.1-1969. Appendix A. Section A3.3 The velocity diatribution acrow the duct or atuck chould be known in order to extablich iscokinotic flow and reprecentative sample points.

Documentation: Facilities Maintenance Support Services Preventive Maintenance Procedure 7-GN-56, Rev 2

\section{GUIDANCE/DATA SHEET FOR 244-S DCRT EXHAUST STACK (296-S-22) FLOW MEASUREMENT}

Comparison: The velocity distribution is not known. However, uniform distribution may be assumed (see discussion under "ANSI N13.1-1969, Appendix A, Section A3.1" above).

The designed isokinetic flow rate in the stack is $3313 \mathrm{~L} / \mathrm{min}$ $\left(117 \mathrm{ft}^{3} / \mathrm{min}\right)$, based on a sample flow of $62.3 \mathrm{~L} / \mathrm{min}\left(2.2 \mathrm{ft}^{3} / \mathrm{min}\right)$. Although, it is not reasonable to assume that the design flow is maintained. To determine the true or actual operating condition isokinetic flow rate sample data and instrumentation errors must be accounted for. From 1992 data, the actual sample flow at the sample nozzle openings (taking into account variability in the readings and instrumentation errors) is from 39.6 to $73.6 \mathrm{~L} / \mathrm{min}$ (1.4 to $2.6 \mathrm{ft}^{3} / \mathrm{min}$ ). From this, the actual or operating isokinetic flow rate in the stack is from 2095 to $3907 \mathrm{~L} / \mathrm{min}$ ( 74 to $138 \mathrm{ft}^{3} / \mathrm{min}$ ). Section Subpart H Section 61.93 (b)(1)(iii) above gives the actual flow rates measured in the stack. The average of this data is $4191 \mathrm{~L} / \mathrm{min}$ (148 $\left.\mathrm{ft}^{3} / \mathrm{min}\right)$ with observable minimum and maximum flow rates between 3454 and $4927 \mathrm{~L} / \mathrm{min}$ (122 and $174 \mathrm{ft}^{3} / \mathrm{min}$ ).

ANSI N13.1-1969. Appendix A. Section A3.4 Sampling probe configuration is recommended by figures in this ANSI Standard, with minimum radius bends and procisely tapered probe end edges.

\section{Documentation: Drawing H-2-46785}

Comparison: This drawing provides the probe as a 1.91-cm (3/4-in.) SCHD 40 pipe with a $7.6 \mathrm{~cm}$ ( 3 in.) 90 degree radius bend and a 3 in. vertical length under that. The inside diameter of this probe is $2.093 \mathrm{~cm}$ (0.824 in.). According to ANSI the bend radius, and the vertical 
should both be 5 times the inside diameter. Five times the inside diameter of this probe is $10.46 \mathrm{~cm}$ (4.12 in.). In addition the nozzle is tapered to a knife edge.

\section{ANSI N13.1-1969. Appendix B. Particle Deposition in Sample Lines}

\section{Documentation: WHC-SD-WM-ES-291, Rev 1}

Comparison: The estimate made for this stack was made using an up-to-date computer software program. The program title is "DEPOSITION 2.0" and is referenced as Anand, N. K., McFarland, A.R., Wong, F.S, Kocmound C.J., DEPOSITION 2.0, NRC NuReg/GR-006, Serial * 2145, March 8, 1993, Aerosol Technology Laboratory, Department of Mechanical Engineering, Texas A\&M University College Station, TX 77843.

Because particle sizes are not known, a spread of particle sizes was used (i.e., 10, 3.5 and 1 micron in size). The results are as follows:

STACK NUMBER 296-S-22 SAMPLING SYSTEM PARTICLE PENETRATION PERCENTAGE

\begin{tabular}{|c|c|c|c|c|c|c|}
\hline & \multicolumn{6}{|c|}{ PARTICLE SIZE } \\
\hline Range & \multicolumn{2}{|c|}{$10 \mu \mathrm{m}$} & \multicolumn{2}{c|}{$3.5 \mu \mathrm{m}$} & \multicolumn{2}{c|}{$1 \mu \mathrm{m}$} \\
\hline & Probe & Total & Probe & Total & Probe & Total \\
\hline Minimum & 95.5 & 9.2 & 98.4 & 78.7 & 99.5 & 97.6 \\
\hline Average & 101.9 & 17.3 & 99.7 & 84.5 & 99.7 & 98.3 \\
\hline Maximum & 115.2 & 40.1 & 101.9 & 91.0 & 100.1 & 99.1 \\
\hline
\end{tabular}

The variables used in this program are as follows:

Stack diameter 6 in. $=0.1524 \mathrm{~m}$

Area $=\pi R^{2}=0.01824 \mathrm{~m}^{2}$

Stack Stream Velocity $(\mathrm{m} / \mathrm{s}): 3.16$ to 4.50

Average: 3.83

Probe Equivalent Radius $=0.412$ in .

Probe Equivalent Diameter $=0.824 \mathrm{in} .=20.9296 \mathrm{~mm}$

Designed Sample Flow Rate $=2.2 \mathrm{ft}^{3} / \mathrm{min}=62.29696 \mathrm{~L} / \mathrm{min}$ 
Sample Flow rate $(\mathrm{L} / \mathrm{min}): 39.64$ to 73.62

Average: 56.63

Line Length $=1.5 \mathrm{ft}=0.4572 \mathrm{~m}$

Tube ID $=0.43$ in. $=10.922 \mathrm{~mm}$

one 90 degree bend.

ANSL N13.1-1969. Appendix C. Errors Due to Anisokinetic Sampling Evaluated with the software discussed above under ANSI N13.1-1969, Appendix B, Particle Deposition in Sample Lines.

Subpart H Section 61.93 (b) (2) (iii) (100 Appendix N)

Subpart H Section 61.23(b)(2)(iv) (noc Appendix N)

Subpart H.Section 61.93(b)(3) (coe Appendix N)

Subpart H Section 61.93(b)(4)(i) (20e Appendix N)

Subpart H Section 61.93(b)(4)(ii) (coc Appendix N)

Subpart H Section 61.23(b)(5) (see Appendix N) 
APPENDIX M

40 CFR 61.93, SUBPART H COMPARISON FOR 296-T-18 
This page intentionally left blank. 


\section{POINT-BY-POINT NESHAP COMPLIANCE COMPARISON FOR THE 244-TX DOUBLE CONTAINED RECEIVER TANK EXHAUSTER STACK NUMBER 296-T-18}

\section{Subpart H Section 61.93 (a) (soc Appendix N)}

Subpart H Section 61.93 (b) Radionuclide emingion rates from point sources (etncks or vents) shall be measured in eccordance with the following requirements or procedures for which EPA hes granted prior approval:

Subpart H Section 61.93 (b)(1) Effluent flow nte measurements shall be made using the following methods:

Subpart H Section 61.93 (b)(1)(i) Reference Method 2 of Appendix A to Part 60 shall be usod to determine velocities and volumetric flow rates for atucks and hrge vents.

Documentation: Drawing: H-2-73839

Comparison: $\quad$ Method 2 is for stacks larger than $30 \mathrm{~cm}$ (12 in.). This stack is smaller than the $30 \mathrm{~cm}$ (12 in.) applicability criteria; it is only $15 \mathrm{~cm}(6 \mathrm{in}$.). Method $2 \mathrm{C}$ is applicable for small stacks. See discussion under Method $2 \mathrm{C}$ below.

Subpart H Section 61.93 (b)(1)(ii) Reference Method 2A of Appendix A to Part 60 ahall be weed to determine velocities and volumetric flow rates through pipea and small ducts.

Documentation: Not applicable.

Comparison: Method 2A is not applicable for stacks. It is applicable for pipes and ducts where the entire effluent is run through a measuring device. This method may be applicable to the sampling systems themselves.

40 CER 60. Appendix A. Reference 2C Determination of Stack Gas Velocity and Volumetric Flow Rate in Small Stacks or Ducts: This method allows for the following:

1. The celection of the measurement site according to Method 1A in Appendix A of 40 CFR 60 .

2. The selection of the number of traverue point measurements per Figure 1-2, "Minimum number of traverse points for velocities (nonparticulate) traverses," in Method 1 in Appendix A of 40 CFR 60.

3. The location of the individual traverse measurement points according to Table 1-2, "Location of Traveree Points in Circular Stacks" of Method 1, of Appendix A of 10 CFR 60.

4. Apparatus

5. Procedure. 
Documentation: Job Control System Work Packages listed under "Subpart H Section 61.93 (b) (1) (iii)"

\section{GUIDANCE/DATA SHEET FOR 244-TX DCRT EXHAUST STACK (296-T-18) FLOW MEASUREMENT}

Facilities Maintenance Support Services Preventive Maintenance Procedure 7-GN-56, Rev 2

Comparison: See the discussion below under "Method 1A, Section 2.1.1: PM Measurement" for selection of the measurement site and requirements. The measurement site is $1.3 \mathrm{~cm}(1 / 2 \mathrm{in}$.) duct diameter under the nozzle opening of the record sampler probe and 9.5 duct diameters above the fan discharge to the stack. Figure 1-2 of Method 1 in Appendix A of 40 CFR 60 specifies 16 measurements if the flow disturbances downstream of the site is less than 1.5 duct diameters. However, this figure is mainly for large stacks (although it is referenced for use with small stacks). In a stack that is $15 \mathrm{~cm}$ (6 in.) in diameter, an increasing number of measurement points begins to get senseless. Logically, there comes a point when additional data points are no longer useful. Therefore it was decided that measurements would be taken on each of 8 annular traverse points located according to Table 1-2, "Location of Traverse Points in Circular Stacks" of Method 1, of Appendix A of 40 CFR 60. This is performed in each of the two perpendicular flow measurement ports.

A standard pitot tube is used as specified. However, the procedure is not exactly duplicated as yet. A new procedure is under development that will duplicate the regulatory procedure.

Subpart H Section 61.93 (b)(1)(iii) The frequency of flow rate measurements shall depend upon the variability of the effluent flow rate. For variable flow nates, continuous or frequent flow nites measurements shall be made. For relatively constant thow rates only periodic measurements are neceasury.

Documentation: The following flows were obtained from this facility. Note, where available the Job Control System Work Package number and date the measurement was taken is given: 


\begin{tabular}{lcl} 
DATE & ELOW $\left(\mathrm{ft}^{3} / \min \right)$ & \multicolumn{1}{c}{ WP\# } \\
$08 / 20 / 90$ & 185 & NONE \\
$11 / 28 / 90$ & 328 & NONE \\
$02 / 26 / 91$ & 333 & NONE \\
$05 / 20 / 91$ & 237 & $2 W-91-00399$ \\
$08 / 26 / 91$ & 284 & $2 W-91-00856$ \\
$04 / 14 / 93$ & 305 & $2 W-92-00525$ \\
$05 / 13 / 93$ & 281 & $2 W-93-00313$ \\
& & \\
AVERAGE & & 279 \\
& \\
VARIABILITY & $-34 \% /+19 \%$ \\
& \\
STANDARD DEVIATION & 53 \\
95\% CONFIDENT INTERVAL & 129 \\
RANGE & 150 to 408
\end{tabular}

Comparison: Although the regulations do not specifically define variable versus constant flow rate, a flow rate with a variability of less than \pm 20 percent has been defined at the Hanford Site as being continuous. This criteria is specified in SD-WM-CR-016. The flow rates given above are therefore, variable. The schedule for taking these flows is quarterly. Although the quarterly schedule is not always met, the requirement at the Hanford Site is to take flow rates at least annually when the exhauster is running. This exhauster does not always run. Its purpose is to run when the temperature of the waste in the tank is above $60^{\circ} \mathrm{C}\left(140^{\circ} \mathrm{F}\right)$ and/or while waste is being transferred through this facility.

Subpart H Section 61.93 (b)(2) Radionuclides shall be directly monitored or extracted, collected, and measured using the following methods:

Subpart H Section 61.93 (b)(2)(i) Reference Method 1 of Appendix A Part 60 shall be used to select monitoring or sampling sites.

40 CFR 60. Appendix A. Method 1 Sample and Velocity Traverses for Stationary Sources.

40 CFR 60. Appendix A. Method 1. Section 1.2: Applicability This method is applicable to flowing gas atreams in ducts, atacks, and flues. This method cannot be used when (1) flow is cyclonic or owirling (eee section 2.4); (2) a stack is smaller than about $0.30 \mathrm{~m}$ (12 in.) in diameter, or 0.071 $\mathrm{m}^{2}\left(113\right.$ in. $\left.{ }^{2}\right)$ cross-ecctional area; or (3) the measurement site is less than two stack or duct diameters downstream or less than a half diameter upstream from a flow disturbance.

Documentation: Drawing H-2-73839 
Comparison: This stack is smaller than the 30-cm (12-in.) applicability criteria; it is only $15 \mathrm{~cm}(6 \mathrm{in}$.$) . See Method 1 \mathrm{~A}$ below.

40 CER 60. Appendix A. Method 1. Section 2.1: Selection of Measurement Site Sampling or velocity measurement is performed at a site located at lean 8 atack or duct diameters downstream and two diameters upstream from any disturbances such as a bend, expansion, or contraction in the atack, or from a visible flame. If neceasary, an alternative location may be selected, at a position at least 2 atack or duct diameters downstream and a half diameter upstream from any flow disturbance.

Not applicable. This stack is smaller than the $30 \mathrm{~cm}$ (12 in.) applicability criteria; it is only $15 \mathrm{~cm}(6 \mathrm{in}$.$) .$

\section{CFR 60. Appendix A. Method 1A. Sample and Velocity Traverses for} Stationary Sources with Small Stacks or Ducts This method is applicable to stacks or ducts leas than about $0.30 \mathrm{~m}\left(12 \mathrm{in}\right.$.) in diameter, or $0.071 \mathrm{~m}^{2}\left(113 \mathrm{in.}{ }^{2}\right)$ cross-sectional area, but equal to or greeter than about $0.10 \mathrm{~m}\left(4 \mathrm{in}\right.$.) in diameter or $0.00812 \mathrm{~m}^{2}\left(12.57 \mathrm{in}\right.$. $\left.^{2}\right)$ in cross-eectional area.

\section{CFR 60. Appendix A. Method 1A. Section 2.1.1: PM Measurement Method 1A calls for the eampling sites preferably to be located at least 8 equivalent stack or duct diameters downstream and 10 equivalent diameters upstream from any flow disturbances. The velocity measurement location is recommended to be at a site located 8 equivalent stack or duct diameters downstream of the sampling site. This method further stipulates that if such locations are not available, then the ampling site should be located at least 2 equivalent stack or duct diameters downstream and $21 / 2$ atack diameters upstream from any flow disturbances. The velocity measurement device ahould then be located 2 equivalent stack diameters downstream from the sampling site.}

\section{Documentation: Drawing H-2-73839}

\section{GUIDANCE/DATA SHEET FOR 244-TX DCRT EXHAUST STACK (296-T-18) FLOW MEASUREMENT}

Facilities Maintenance Support Services Preventive Maintenance Procedure 7-GN-56, Rev 2

Comparison: This stack is smaller than the $30 \mathrm{~cm}$ (12 in.) applicability criteria; it is only $15 \mathrm{~cm}(6 \mathrm{in}$.$) .$

This stack is $15 \mathrm{~cm}$ (6 in.) in diameter. The sample probe

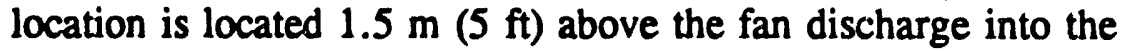
stack. The closest flow disturbances are:

Downstream the nozzle opening of the sample probe is 2 duct diameters below the nozzle opening of the CAM sample probe.

Upstream the fan discharge into the stack is 9.5 duct diameters below the nozzle opening of the sa nple probe. 
Flow measurements are accomplished via Facilities Maintenance Support Services Preventive Maintenance Procedure 7-GN-56, Rev 2. There are two perpendicular ports chosen for the measurement. These ports are one duct diameter below the center line of the record sample probe (the record sample probe extends 6 vertical inches down from its centerline) and 9.5 duct diameters above the fan discharge into the stack. Although this location is not downstream of the sample probe, it is considered to be a conservative location for measurement purposes for two reasons:

1. Three sample probes are on this stack. Two are for continuous monitors and one is for the record sampler. Each probe draws a sample at a rate of approximately $57 \mathrm{~L} / \mathrm{min}\left(2 \mathrm{ft}^{3} / \mathrm{min}\right)$ of air flow from the stack to total $170 \mathrm{~L} / \mathrm{min}\left(6 \mathrm{ft}^{3} / \mathrm{min}\right)$. This sample flow taken from the average stack flow given above of $7900 \mathrm{~L} / \mathrm{min}$ (279 $\left.\mathrm{ft}^{3} / \mathrm{min}\right)$, will result in $2042 \mathrm{~L} / \mathrm{min}\left(273 \mathrm{ft}^{3} / \mathrm{min}\right)$ downstream of all three sample probes. Although $170 \mathrm{~L} / \mathrm{min}\left(6 \mathrm{ft}^{3} / \mathrm{min}\right)$ only represents 2 percent of the average stack flow, a more conservative representation of the actual totalized flow can be gained from the measurement occurring below the sample probes. Totalized flow is necessary for total emission calculations.

2. Because the probes are removing air from the stack stream, the location of the flow measurement below the sample probes give a truer representation of the flow rate for the first sample probe (the record sampler). This allows for a truer representation of the isokinetic flow conditions that are used to determine the efficiency of the system.

Measurements are taken on each of 8 annular traverse points located according to Table 1-2, "Location of Traverse Points in Circular Stacks" of Method 1, of Appendix A to this same regulation. This is performed in each of the two perpendicular flow measurement ports.

Subpart H Section 61.93 (b) (2) (ii) The effluent stream shall be directly monitored continuously with an in-line detector or representative sumples of the effluent atream shall be withdrawn continuously from the sampling site following the guidance presented in ANSI N13.1-1969 "Guide to Sampling Airborne Radioactive Materials in Nuclear Facilities" (including the guidance presented in Appendix A of ANSIN13.1). 
ANSI N13.1-1969. Guide te Sampling Airborne Radioactive Materials in Nuclear Facilities The guidance of this atandard atart in Section 4. Principles. Section 4.1 is General, Section 4.2 is Representative Samples, Section 4.2.1 is Samples Representative Acconding to Spacial Location, Section 4.2.1.1 is Sampling in a Zone Occupies by Workers. The first rection in this ANSI ctandard applicable to the comparieon of this document is 4.2.1.2.

ANSI N13.1-1969. Section 4.2.1.2 Sampling point ahould be a minimum of 5 diameters (or 5 times the major dimension for rectangular ducts) downetream from abrupt changes in flow direction or prominent transitions.

Not applicable. 40 CFR 61.93 (b)(2)(i) specifies the site location. See comparison under "Method 1A, Section 2.1.1: Selection of Measurement Site."

ANSI N13.1-1969. Section 4.2.2 Samples should be representative with respect to physical and chemical composition of airtream.

Documentation: WHC-SD-WM-EMP-031, Rev 0

Comparison: No particle size studies have been performed at this facility, although a particle loss determination has been informally (at this time) accomplished. Information given in WHC-SD-WM-EMP-031, Rev 0 suggest that the sample should consist mainly of ${ }^{89190} \mathrm{Sr},{ }^{137} \mathrm{Cs}$, and ${ }^{239 / 20} \mathrm{Pu}$. These radionuclides are particulate in nature and are not volatile.

ANSI N13.1-1969. Section 4.3. Sample Programming Many factors enter into the design of a earupling program. The sampling program includes the frequency, duration, and volume rate of sampling. In most cases, the selection of these three elements in programming will be a compromise between ideal values and those which provide safety and yet are technically, economically, and conveniently achieved.

ANSI N13.1-1969. Section 4.3.1 (see Appendix N)

ANSI N13.1-1969, Section 4.3.2 (20e Appendix N)

ANSI Ni3.1-1969. Section 4.3.3 (20e Appendix N)

ANSI N13.1-1969. Section 4.3.4 (see Appendix N)

ANSI N13.1-1969. Section 4.3.5 (see Appendix N)

ANSI N13.1-1969, Section 5, Methods

ANSI N13.1-1969. Section 5.1. General Two forms of airborne radioactive materials are particulate and gases; the particles can be elid or liquid, although particulates are generally considered to be very small fragments of solids. . .

Documentation: WHC-SD-WM-EMP-031, Rev 0 
Comparison: Information given in WHC-SD-WM-EMP-031 suggest that the sample should consist mainly of ${ }^{89 / 80} \mathrm{Sr},{ }^{137} \mathrm{Cs}$, and ${ }^{2391200} \mathrm{Pu}$. These radionuclides are particulate in nature and are not volatile.

\section{ANSI N13.1-1969. Section 5.2. Particles}

ANSI N13.1-1969. Section 5.2.1. Sample Delivery Principles concerning the removal of a representative portion of a contained atream, a from a large duct, have been presented in Section 4. . .

ANSI N13.1-1969. Section 5.2.2. Particle Collectors without Significant Size Differentiation Various collectors are applicable to sampling airborne radioactive materials. . .

ANSIN13.1-1969. Section 5.2.2.1 (200 Appendix N)

ANSI N13.1-1969, Section 5.2.2.1.7 (soe Appendix N)

ANSI N13.1-1969. Section 5.3. Gases Airborne radianctive volatile materials and co-called "permanent" gaees auch as tritium are frequently important contaminants and their campling and collection require techniques and methods differing from those used in particulate sampling.

Documentation: WHC-SD-WM-EMP-031, Rev 0

Comparison: No volatile radionuclides are present at this facility

ANSI N13.1-1969. Section 6.0 (see Appendix N)

ANSI N13.1-1969. Appendix A. Section A1 Minimization of the length and bends of sample delivery lines will contribute to representative sampling.

Documentation: Drawing H-2-73812 and field walkdown

Comparison: The sample line is approximately $.457 \mathrm{~m}(1.5 \mathrm{ft})$ long with a single 90 degree bend. The tube is $1.3 \mathrm{~cm}(1 / 2 \mathrm{in}$.) OD by $0.09 \mathrm{~cm}$ (0.035 in.) wall.

ANSI N13.1-1969. Appendix A. Section A2 The distance from the last upstream disturbance to the point of sample extraction should be a minimum of 5 and preferably ten or more duct diameters downstream. Sampling from a vertical run avoids stratification due to gravity settling. Sampling as far downstream as possible avoids most transient variation in airstream quality.

Not applicable. 40 CFR 61.93 (b)(2)(i) specifies the site location. See comparison under "Method 1A, Section 2.1.1: Selection of Measurement Site."

ANSI N13.1-1969. Appendix A. Section A3.1 Velocity and flow distribution should be known for the rampling point, and particle and gaseous composition should be representative.

Documentation: Not applicable. 
Comparison: Velocity measurements are accomplished by Facilities Maintenance Support Services Preventive Maintenance Procedure 7-GN-56, Rev 2, Airflow Capacity and Distribution Tests in conjunction with supplemental GUIDANCE/DATA SHEET FOR 244-TX DCRT EXHAUST STACK (296-T-18) FLOW MEASUREMENT. From the section above, "Subpart H Section 61.93 (b)(1)(iii)," the average flow rate was observed to be $7900 \mathrm{~L} / \mathrm{min}\left(279 \mathrm{ft}^{3} / \mathrm{min}\right)$. For a $15-\mathrm{cm}$ (6-in.) stack, this amounts to a velocity of $7.3 \mathrm{~m}(24 \mathrm{ft}) /$ second. According to Table A1 in the ANSI N13.1-1969 Standard laminar flows occur below $.207 \mathrm{~m}(0.68 \mathrm{ft}) /$ second. Above that turbulent flows exist. Figure M-1 shows the velocity distribution for this stack, which is based on a limited amount of data. Note that the flow measurement location is 6 duct diameters upstream from the sampling locating. Since there are no flow disturbances between the flow measurement location and the sampling location, the distribution should be much more uniform at the sampling location. Use the following equation to convert from velocity pressure (inches water, gauge) to velocity (feet per minute).

Velocity $=4005 * \sqrt{\text { VelocityPressure }}$ 
Figure M-1. Stack Flow Distribution 296-T-18-A.

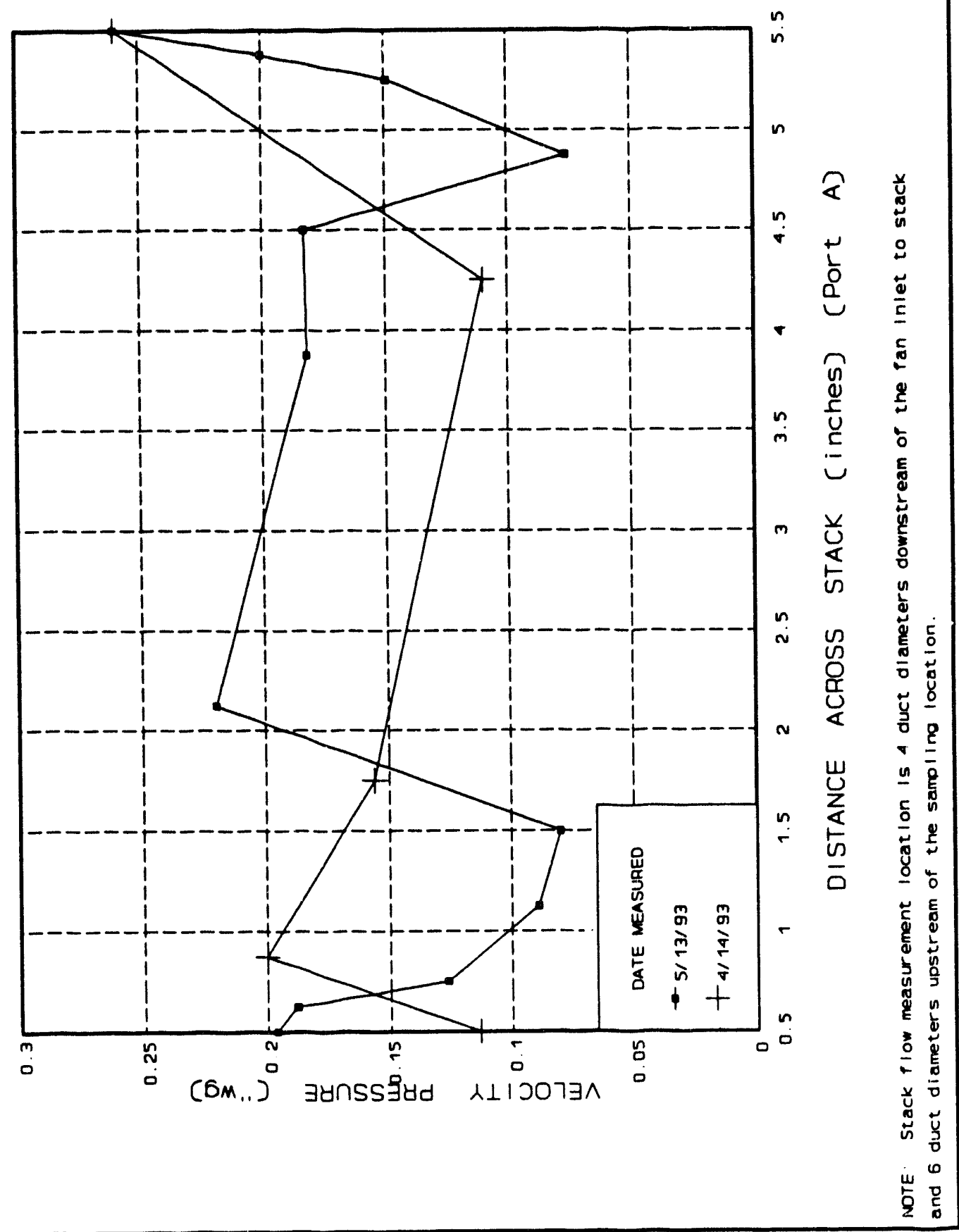


ANSI N13.1-1969. Appendix A. Section A3.2 A multiple number of withdrawal points each representing approximately equal arese besed on the duct or stack dimensions is desirable.

Documentation: Drawing H-2-73812

Comparison: This drawing shows the probe with one nozzle. This is as recommended in this section of the ANSI N13.1-1969 Standard for this size stack [15 cm (6 in.)].

ANSI N13.1-1969. Appendix A. Section A3.3. The velocity dietribution acroes the duct or atack ahould be known in order to establich inokinetic flow and representative aumple points.

Documentation: Facilities Maintenance Support Services Preventive Maintenance Procedure 7-GN-56, Rev 2

\section{GUIDANCE/DATA SHEET FOR 244-TX DCRT EXHAUST STACK (296-T-18) FLOW MEASUREMENT}

Comparison: The velocity distribution is not known. However, uniform distribution may be assumed (see discussion under "ANSI N13.1-1969, Appendix A, Section A3.1" above).

The designed isokinetic flow rate in the stack is $7673 \mathrm{~L} / \mathrm{min}$ (271 $\left.\mathrm{ft}^{3} / \mathrm{min}\right)$, based on a sample flow of $62.3 \mathrm{~L} / \mathrm{min}\left(2.2 \mathrm{ft}^{3} / \mathrm{min}\right)$. Although, it is not reasonable to assume that the design flow is maintained. To determine the true or actual operating condition isokinetic flow rate sample data and instrumentation errors must be accounted for. From 1992 data, the actual sample flow at the sample nozzle openings (taking into account variability in the readings and instrumentation errors) is from 42.5 to $70.8 \mathrm{~L} / \mathrm{min}(1.5$ to $2.5 \mathrm{ft}^{3} / \mathrm{min}$ ). From this, the actual or operating isokinetic flow rate in the stack is from 5210 to $8721 \mathrm{~L} / \mathrm{min}\left(184\right.$ to $308 \mathrm{ft}^{3} / \mathrm{min}$ ). Section Subpart H Section 61.93 (b)(1)(iii) above gives the actual flow rates measured in the stack. The average of this data is $7900 \mathrm{~L} / \mathrm{min}\left(279 \mathrm{ft}^{3} / \mathrm{min}\right)$ with a 95 percent confidence that this flow rate will be between 4247 to $11,552 \mathrm{~L} / \mathrm{min}\left(150\right.$ to $\left.408 \mathrm{ft}^{3} / \mathrm{min}\right)$.

ANSI N13.1-1969. Appendix A. Section A3,4 Sampling probe configuration is recommended by figures in this ANSI Standard, with minimum radius bends and precisely tapered probe end edges.

Documentation: Drawing H-2-73812 
Comparison: This drawing shows the probe as a $1.3 \mathrm{~cm}$ (1/2-in.) SCHD 80 pipe with a 7.6-cm (3-in.) 90 degree radius bend and a $7.6-\mathrm{cm}(3-\mathrm{in}$. vertical length under that. The inside diameter of this probe is 1.387 $\mathrm{cm}(0.546 \mathrm{in}$.). According to ANSI the bend radius, and the vertical should both be 5 times the inside diameter. Five times the inside diameter of this probe is $6.93 \mathrm{~cm}(2.73 \mathrm{in}$.). In addition the nozzle is tapered to a knife edge.

\section{ANSL N13.1-1969. Appendix B. Particle Deposition in Sample Lines}

Documentation: WHC-SD-WM-ES-291, Rev 1

Comparison: The estimate made for this stack was made using an up-to-date computer software program. The program title is "DEPOSITION 2.0" and is referenced as Anand, N. K., McFarland, A.R., Wong, F.S, Kocmound C.J., DEPOSITION 2.0, NRC NuReg/GR-006, Serial \# 2145, March 8, 1993, Aerosol Technology Laboratory, Department of Mechanical Engineering, Texas A\&M University College Station, TX 77843. This program also provides for anisokinetic sampling affects as discussed in ANSI N13.1-1969, Appendix C.

Because particle sizes are not know a spread of particle sizes were used 10, 3.5 and 1 micron in size. The results are as follows:

STACK NUMBER 296-T-18 SAMPLING SYSTEM PARTICLE PENETRATION PERCENTAGE

\begin{tabular}{|c|c|c|c|c|c|c|}
\hline & \multicolumn{5}{|c|}{ PARTICLE SIZE } \\
\hline Range & \multicolumn{2}{|c|}{$10 \mu \mathrm{m}$} & \multicolumn{2}{c|}{$3.5 \mu \mathrm{m}$} & \multicolumn{2}{c|}{$1 \mu \mathrm{m}$} \\
\hline & Probe & Total & Probe & Total & Probe & Total \\
\hline Minimum & 84.0 & 8.8 & 95.2 & 76.9 & 98.6 & 96.8 \\
\hline Average & 94.9 & 16.1 & 97.1 & 82.3 & 98.9 & 97.4 \\
\hline Maximum & 129.8 & 39.4 & 103.8 & 91.9 & 99.6 & 98.5 \\
\hline
\end{tabular}

The variables used to derive the values in this table are as follows:

Stack diameter $6.065 \mathrm{in} .=0.154 \mathrm{~m}$

Area $=\pi R^{2}=0.0186 \mathrm{~m}^{2}$

Stack Stream Velocity $(\mathrm{m} / \mathrm{s}): 3.81$ to 10.35 
Average: 7.08

Probe Equivalent Radius $=0.273$ in.

Probe Equivalent Diameter $=0.546 \mathrm{in} .=13.8684 \mathrm{~mm}$

Designed Sample Flow Rate $=2.2 \mathrm{ft}^{3} / \mathrm{min}=62.29696 \mathrm{~L} / \mathrm{min}$

Sample Flow rate $(\mathrm{L} / \mathrm{min}): 42.47$ to 70.79

Average: 56.63

Line Length $=1.5 \mathrm{ft}=0.4572 \mathrm{~m}$

Tube $\mathrm{ID}=0.43 \mathrm{in}$. $=10.922 \mathrm{~mm}$

one $90^{\circ}$ bend

ANSI N13.1-1969. Appendix C, Frrors Due to Anisokinetic Sampling Evaluated with the software discussed above under ANSI N13.1-1969, Appendix B, Particle Deposition in Sample Lines.

Subpart H. Section 61.93 (b) (2) (iii) (see Appendix N)

Subpart H Section 61.93(b)(2)(iv) (roc Appendix N)

Subpart H Section 61.93(b)(3) (sec Appendix N)

Subpart H Section 61.93(b)(4)(i) (200 Appendix N)

Subpart H Section 61.93(b)(4)(ii) (see Appendix N)

Subpart H Section 61.93(b)(5) (co Appendix N) 

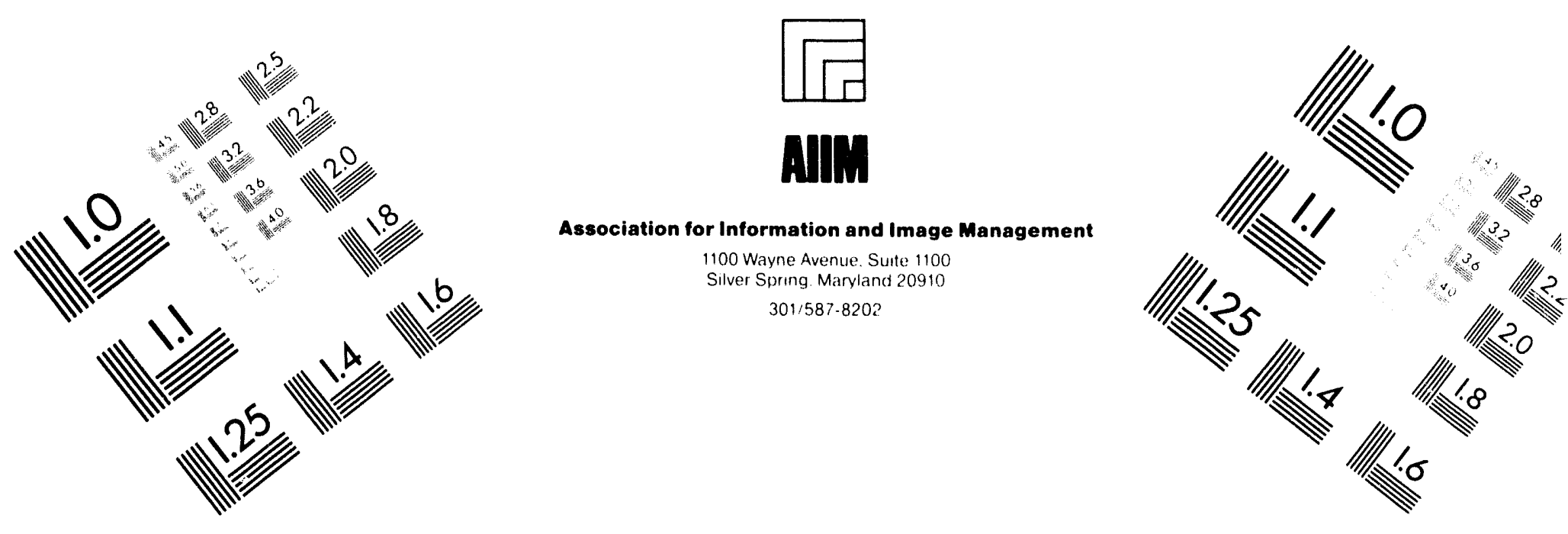

Centimeter

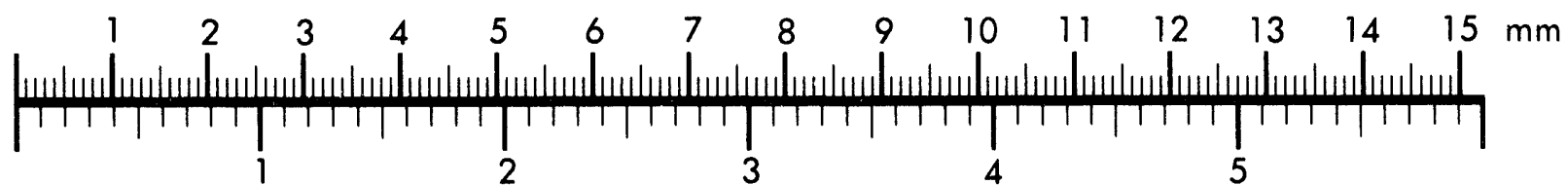
Inches
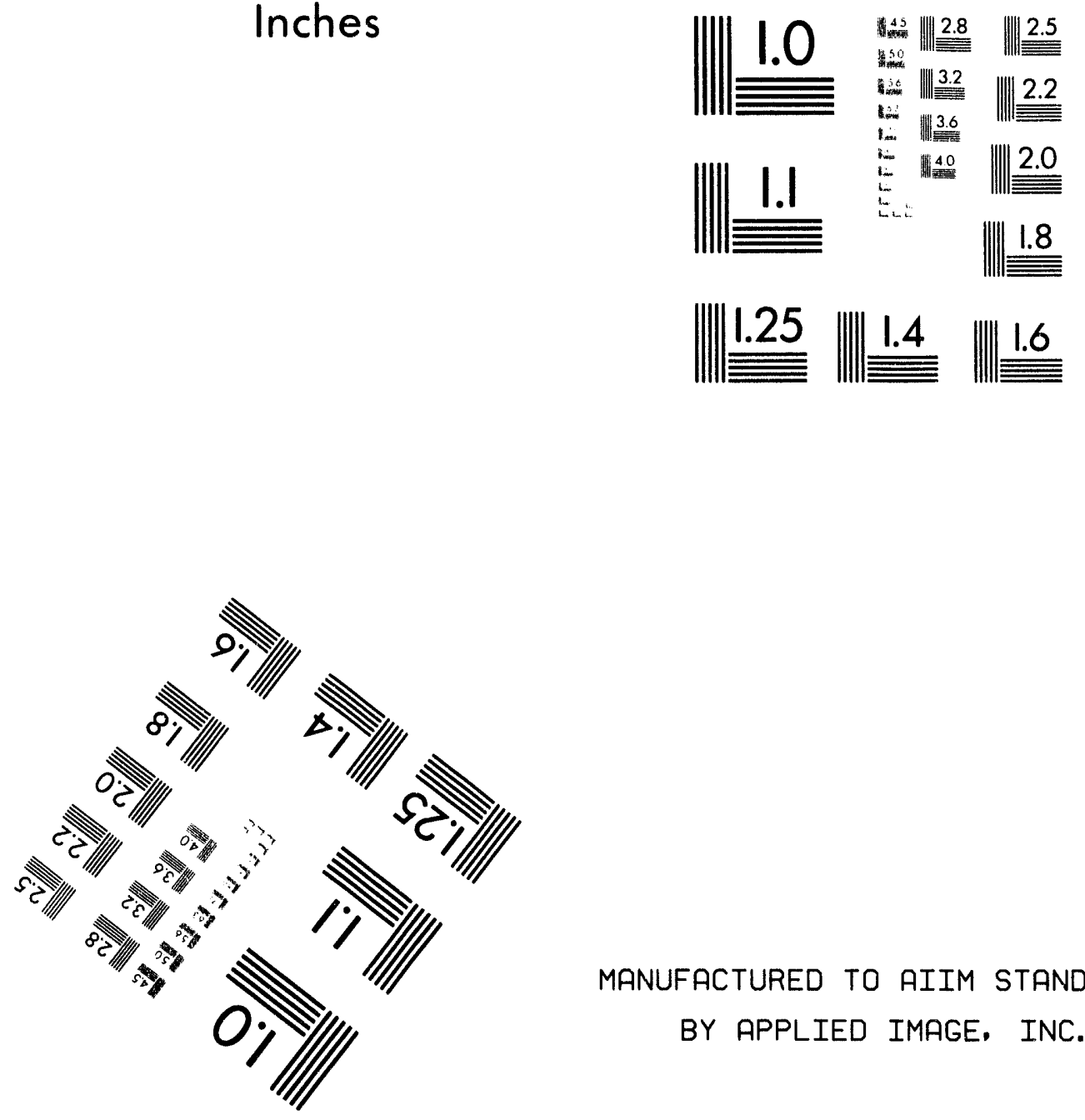

MANUFACTURED TO AIIM STANDARDS BY APPLIED IMAGE. INC.

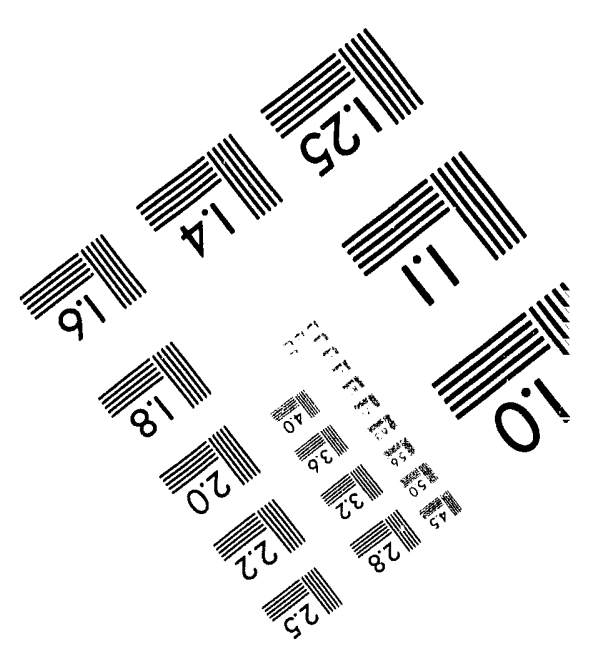



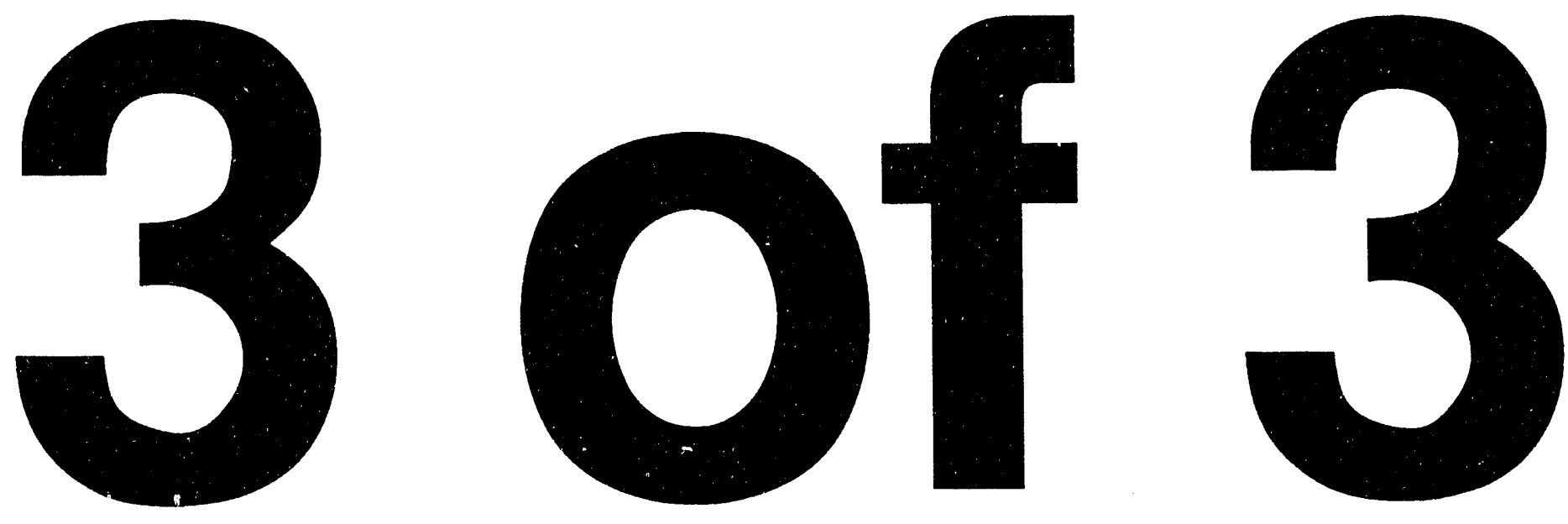
APPENDDX N

SECTIONS COMMON TO EVERY POINT-BY-POINT 
This page intentionally left blank. 


\section{SECTIONS COMMON TO EVERY POINT-BY-POINT}

Subpart H Section 61.93 (a) To determine compliance with the attandand, radionuclide emiscions shall be determined and effective dose equivalent values to members of the public calculated using EPA approved sampling procedures, computer modele CAP-88 or AIRDOS-PC, or other procodurea for which EPA has granted prior approval. DOE facilities for which the maximally exponed individual lives within 3 kilometers of all sources of emiesions in the facility, may use EPA's COMPLY model and associnted procedures for determining dose for purposes of compliance.

Documentation: WHC-SD-WM-EMP-031, Rev 0

DOE/RL-93-36

Comparison: The effective dose equivalent values to members of the public for the stacks in this document are listed below.

\begin{tabular}{|c|c|c|c|c|}
\hline STACK \# & RADIONUCLIDE & $\begin{array}{l}\text { CAP-88** } \\
\text { (mrem/Ci) }\end{array}$ & $\begin{array}{c}1992 \\
\text { EMISSIONS } \\
\text { (Ci) }\end{array}$ & $\begin{array}{c}1992 \mathrm{EDE} \\
\text { (mrem/year) }\end{array}$ \\
\hline 296-A-17 & $\begin{array}{l}{ }^{80} \mathrm{Sr} \\
{ }^{129} \mathrm{I} \\
{ }^{137} \mathrm{Cs} \\
\text { TOTAL ALPHA }\end{array}$ & $\begin{array}{l}4.38 \mathrm{E}-02 \\
2.91 \mathrm{E}-01 \\
2.39 \mathrm{E}-02\end{array}$ & 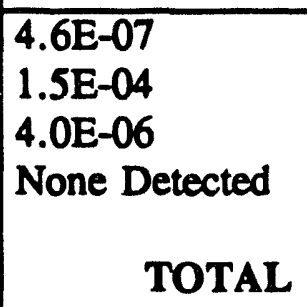 & $\begin{array}{l}2.0 \mathrm{E}-08 \\
4.4 \mathrm{E}-05 \\
9.6 \mathrm{E}-08 \\
0 \\
4.4 \mathrm{E}-05\end{array}$ \\
\hline 296-P-26 & $\begin{array}{l}\text { (emissions from this } \\
\text { stack are reported } \\
\text { with stack 296-A- } \\
\text { 17) }\end{array}$ & & & \\
\hline $296-A-25$ & & & None Detected & 0 \\
\hline $296-A-27$ & $\begin{array}{l}{ }^{\circ} \mathrm{Sr} \\
\text { TOTAL ALPHA }\end{array}$ & $4.38 \mathrm{E}-0.2$ & \begin{tabular}{|r}
$.2 \mathrm{E}-08$ \\
TOTAL \\
TOL
\end{tabular} & $\begin{array}{l}1.8 \mathrm{E}-09 \\
1.8 \mathrm{E}-09\end{array}$ \\
\hline $296-A-29$ & $\begin{array}{l}\text { TOTAL ALPHA } \\
\text { TOTAL AETA }\end{array}$ & 4.38E-0.2 & $\begin{array}{l}\text { None Detected } \\
\text { 4.1E-06 } \\
\text { TOTAL }\end{array}$ & $\begin{array}{l}1.8 \mathrm{E}-07 \\
1.8 \mathrm{E}-07\end{array}$ \\
\hline 296-B-28 & $\begin{array}{l}\text { TOTAL ALPHA } \\
\text { TOTAL BETA }\end{array}$ & $\begin{array}{l}1.31 \mathrm{E}+01 \\
4.38 \mathrm{E}-0.2\end{array}$ & 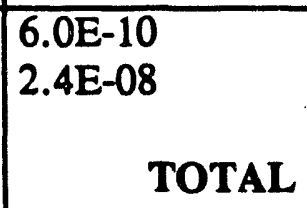 & $\begin{array}{l}7.9 \mathrm{E}-09 \\
1.1 \mathrm{E}-09 \\
8.9 \mathrm{E}-09\end{array}$ \\
\hline
\end{tabular}




\begin{tabular}{|c|c|c|c|c|}
\hline STACK \# & RADIONUCLIDE & $\begin{array}{l}\text { CAP-88** } \\
(\mathrm{mrem} / \mathrm{Ci})\end{array}$ & $\begin{array}{c}1992 \\
\text { EMISSIONS } \\
\text { (Ci) }\end{array}$ & $\begin{array}{c}1992 \mathrm{EDE} \\
\text { (mrem/year) }\end{array}$ \\
\hline 296-P-28 & $\begin{array}{l}\text { (emissions from this } \\
\text { stack are reported } \\
\text { with stack 296-P-23) }\end{array}$ & & & \\
\hline $296-C-5$ & $\begin{array}{l}\text { TOTAL ALPHA } \\
\text { TOTAL BETA }\end{array}$ & $\begin{array}{l}1.31 \mathrm{E}+01 \\
4.38 \mathrm{E}-02\end{array}$ & $\begin{array}{r}2.9 \mathrm{E}-09 \\
2.7 \mathrm{E}-07 \\
\\
\text { TOTAL }\end{array}$ & $\begin{array}{l}3.8 \mathrm{E}-08 \\
1.2 \mathrm{E}-08 \\
5.0 \mathrm{E}-08 \\
\end{array}$ \\
\hline $296-P-16$ & $\begin{array}{l}\text { TOTAL ALPHA } \\
\text { TOTAL BETA }\end{array}$ & $\begin{array}{l}1.31 \mathrm{E}+01 \\
4.38 \mathrm{E}-02\end{array}$ & $\begin{aligned} \begin{array}{l}4.1 \mathrm{E}-09 \\
1.3 \mathrm{E}-05\end{array} & \\
& \text { TOTAL } \\
& \end{aligned}$ & $\begin{array}{l}5.4 \mathrm{E}-08 \\
5.7 \mathrm{E}-07 \\
6.2 \mathrm{E}-07\end{array}$ \\
\hline $296-P-23$ & $\begin{array}{l}\text { TOTAL ALPHA } \\
\text { TOTAL BETA }\end{array}$ & $\begin{array}{l}7.79 \mathrm{E}+00 \\
2.60 \mathrm{E}-02\end{array}$ & $\begin{array}{r}\text { 6.6E-10 } \\
9.1 \mathrm{E}-07 \\
\\
\text { TOTAL }\end{array}$ & $\begin{array}{l}5.1 \mathrm{E}-09 \\
2.4 \mathrm{E}-08 \\
\\
2.9 \mathrm{E}-08\end{array}$ \\
\hline $296-S-15$ & $\begin{array}{l}\text { TOTAL ALPHA } \\
\text { TOTAL BETA }\end{array}$ & $2.60 \mathrm{E}-02$ & $\begin{array}{l}\text { None Detected } \\
1.1 \mathrm{E}-07 \\
\text { TOTAL } \\
\text { ToT }\end{array}$ & $\begin{array}{l}2.9 \mathrm{E}-09 \\
2.9 \mathrm{E}-09\end{array}$ \\
\hline $296-S-22$ & & & None Detected & 0 \\
\hline $296-T-18$ & TOTAL BETA & $2.60 \mathrm{E}-02$ & $\begin{array}{r}3.0 \mathrm{E}-08 \\
\text { TOTAL }\end{array}$ & $\begin{array}{l}7.8 \mathrm{E}-10 \\
7.8 \mathrm{E}-10\end{array}$ \\
\hline
\end{tabular}

** Assuming TOTAL BETA is from ${ }^{90} \mathrm{Sr}$, TOTAL ALPHA is from ${ }^{241} \mathrm{Am}$

ANSI N13.1-1969. Section 4.2.2.2 SAMPLING WTTH DELIBERATE DIFFERENTIATION AS TO PARTICLE SIZES. Because knowledge of particle size distribution is important to a correct evaluation of radiological effects, eamplers and collectors may be deliberately designed to identify two or more size fractions of the airborne material.

Documentation: RHO-CD-1092

Comparison: The sampling systems are not designed to deliberately differentiate between particle sizes.

ANSI N13.1-1969. Section 4.3.1 SENSITIVITY OF DETECTION AND MEASUREMENT. Sensitivity and accuracy of the analytical or counting method will determine the minimum volume of air which must be ampled to obtain the requisite accuracy and precision of results. 
Documentation:

Comparison:

ANSI N13.1-1969. Section 4.3.2 PERMISSIBLE LEVELS AT POINT OF SAMPLING. If poesible, the ample abould be large onough to permit $1 / 10$ the permiesible level to be determined with reliability.

Documentation: None.

Comparison: $\quad$ Refer to ANSI N13.1-1969, Section 4.3.1

ANSI N13.1-1969. Section 4.3.3 RADIOACTIVITY DECAY. The radioactive half-life of the nuclide to be measured is an important consideration.

Documentation: WHC-EP-0536-1

Comparison: Radioactivity decay is addressed in Appendix G of the referenced plan.

ANSIN13.1-1969. Section 4.3.4 NATURAL RADIOACTIVE MATERIALS. The presence of natural radioactive materials of thort half-life may mask the presence of aignificant quantities of longer lived materials.

Documentation: WHC-EP-0536-1

Comparison: Natural ratioactive materials are addressed in Appendix $G$ of the referenced jlan.

ANSI N13.1-1969. Section 4.3.5 SPECIFIC NATURE OF THE OPERATION OR PROCESS. The nature of the operation which creates the potential for airborne radionctive materials may influence the sampling program. When the purpose of the eampling is to establish the total release of radioactive materials to the environment, the sampling program must be designed to ensure obtaining an adequate sample during accidental releases.

\section{Documentation: WHC-SD-WM-EMP-031}

Comparison: The operation of the facilities is described in the referenced document. The types of accidental releases that would most likely occur are 1) loss of negative tank pressure due to exhauster failure, 2) loss of negative tank pressure due to a gas bubble, 3) catastrophic failure, or 4) HEPA filter failure. In the first three instances, the environmental or area monitoring system would be relied upon to obtain a sample. In the fourth instance the stack sampling system and the area monitoring system would be relied upon to obtain a sample. 
ANSI N13.1-1969. Section 5.2.2.1 FIITERS. Appropriate filtration should be chosen for ampling.

Documentation: Gelman Sciences, Inter-Office Memorandum to Karol Butcher October 30, 1991, RE: Versapor 3000, DOP efficiency.

WHC-IP-0692

Health Physics Procedure No. 3.3.2, Rev 2

Comparison: $\quad 47 \mathrm{~mm}$ Versapor 3000 or equivalent air sample filter is used for the record sampler. This filter is a membrane filter good for collecting $0.3 \mu \mathrm{m}$ size particles with a collection efficiency of 95.8 percent.

ANSI N13.1-1969. Section 5.2.2.1.7 RELATED EQUIPMENT FOR FILTER SAMPLING. Filter holder and aupport should be chosen for proper chemical compatibility, mechanical strength, sealing, and ease of operation in changing filters. Sample air movers should have the capability of delivering the necesary air flow againat the reaistance of the campling system. Proper location and choice of flow mearurement iuvice and flow rate control is important.

Documentation: WHC-SD-WM-ES-291

Comparison: The entire stack radionuclide sampling system consists of the following elements and their corresponding functions:

- The sampling probe withdraws the sample from the stack.

- The sample transport line transports the sample to a sample collection (the record sampler) and/or other detection devices (the CAMs).

- The collection and/or detection devices collect the sample.

- The rotameter measures the flow through the system.

- The gasmeter or totalizer totals the sample flow.

- The pressure or vacuum gauge measures the vacuum in the system.

- The flow switch indicates when the sample flow falls below established limits.

- The flow regulator is used to adjust the flow to maintain established flow rates within the system. 
- The vacuum pump supplies the flow through the system.

- The timer indicates the length of time the collection devices have operated.

ANSI N13.1-1969. Section 5.3 GASES. (NOTE: This section is not applicable to all of the tacks evahuated in this document) Airborne radioactive volatile materials and co-called "permanent" gaces ach as tritium are frequently important contaminants and their ampling and collection require techniques and mothods differing from those used in particulate sampling.

\section{Documentation: WHC-IP-0718}

- 200 Area Health Physics Procedure No. 3.3.2, Rev 1

Comparison: $\quad$ Silver zeolite cartridges are used and are designed to collect ${ }^{129} \mathrm{I},{ }^{131} \mathrm{I}$, ${ }^{125} \mathrm{Sb},{ }^{113} \mathrm{Sn},{ }^{100} \mathrm{Ru}$, and ${ }^{106} \mathrm{Ru}$. WHC presently uses two manufacturers:

\section{SAIC/RADECO}

10373 Roselle Street

San Diego, Ca 92121

or

HI-Q Environmental Products Co

PO Box 2847

LaJolla, Ca 92038-2847.

The gross filter efficiency of a silver zeolite sampler is based on the particular absorbed/adsorbed radionuclide being evaluated and the porosity of the filter. For uses at the Hanford Site (i.e., ruthenium, iodine) the efficiency is 99.2 to 99.98 (taken from Table 0-2 of Air Sampling Instruments, ACGIH, 7th edition, 1989).

ANSI N13.1-1969. Section 6.0 VALIDATION OF SAMPLE EFFECTIVENESS. In a corresponding manner the results from sampling a stack or other exhaust from a facility should be consistent with the results obtained from air eamples drawn downwind or in the vicinity of the facility. 
Documentation: DOE/RL-93-36

WHC-EP-0573-1

Comparison: The stack sampling results are compared in Section 4 of DOE/RL 93-36 to the area monitoring system results.

Subpart H Seation 61.93(b)(2)(III) Radionuolides thall be collooted and meanurod uning procodureas based on the principles of mesurements desoribed in Appendix B, Method 114.

\section{Documentation: WHC-EP-0536-1}

Comparison: A point-by-point comparison for 40 CFR 61, Appendix B, Method 114, Test Methods for Measuring Radionuclide Emissions from Stationary Sources is provided in WHC-EP-0536-1.

Subpart H Section 61.93(b)(2)(iv) A quality aasurance program shall be conductod that mocts the performanco requirements described in Appendix B, Mochod 114.

\section{Documentation: WHC-EP-0536-1}

Comparison: The quality assurance plan referenced above should be updated to include this stack.

Subpart H Section 61.93(b)(3) When it is impractical to measure the efluent flow nto at an exinting source in acoondance with the requirements of Paragraph (b)(1) of this soction, or to monitor or ample an efmuent stream at ast existing sourco in 2000 rdance with the site seloction and eumple extraction requirements of paragraph (b)(2) of this rection, the facility owner or operator may use altermative ofmuent how rate measurement procodures or site seloction and ample extnation procedures provided that:

Comparison: Not applicable to the discussion within this point-by-point.

Subpart H Section 61.93(b)(4)(i) Redionuclide emiseion measurements in conformance with the requirements of paragraph (b) of this scotion shall be made at all release points which have a potential to discharge radionuclides into the air in quantities which could cause an effective dose equivalent in excess on 1 percent of the standard. All Radionuclides which could contribute greater than 10 percent of the potential effective dose oquivalent for a release pount shall be measured. With prior EPA approval, DOE may determine these emiasions through alternative procedures. For other release points which have the potential to release radionuclides into the air, periodic confirmatory measurements ahall be made to verify the low emissions.

\section{Documentation: WHC-SD-WM-EMP-031}


Comparison: The referenced document identifies stacks which have the potential to discharge radionuclides into the air which could cause an effective dose equivalent in excess of 1 percent of the standard. Radionuclides which could contribute greater than 10 percent of the potential effective dose equivalent for each of the designated stacks are listed below.

\begin{tabular}{|c|c|c|}
\hline STACK \# & RADIONUCLIDES > $>10 \%$ of EDE & RADIONUCLIDES MEASURED \\
\hline 296-A-17 & ${ }^{137} \mathrm{Cs}$ & $\begin{array}{l}{ }^{99190} \mathrm{Sr},{ }^{106} \mathrm{Ru} / \mathrm{Rh},{ }^{129} \mathrm{I},{ }^{137} \mathrm{Cs} \text {, Total } \\
\text { Alpha, Total Beta }\end{array}$ \\
\hline 296-P-26 & ${ }^{137} \mathrm{Cs}$ & $\begin{array}{l}{ }^{89990} \mathrm{Sr},{ }^{137} \mathrm{Cs} \text {, Total Alpha, Total } \\
\text { Beta }\end{array}$ \\
\hline $296-A-25$ & $\begin{array}{l}{ }^{137} \mathrm{Cs},{ }^{154} \mathrm{Eu},{ }^{228} \mathrm{Pu},{ }^{299}{ }^{2020} \mathrm{Pu},{ }^{211} \mathrm{Pu}, \\
{ }^{21} \mathrm{Am}\end{array}$ & Total Alpha, Total Beta \\
\hline $296-A-27$ & ${ }^{137} \mathrm{Cs},{ }^{211} \mathrm{Am}$ & $\begin{array}{l}{ }^{89190} \mathrm{Sr},{ }^{100} \mathrm{Ru} / \mathrm{Rh},{ }^{129} \mathrm{I},{ }^{137} \mathrm{Cs} \text {, Total } \\
\text { Alpha, Total Beta }\end{array}$ \\
\hline $296-A-29$ & ${ }^{137} \mathrm{Cs},{ }^{211} \mathrm{Am}$ & $\begin{array}{l}{ }^{89 / 90} \mathrm{Sr},{ }^{137} \mathrm{Cs} \text {, Total Alpha, Total } \\
\text { Beta }\end{array}$ \\
\hline 296-B-28 & ${ }^{137} \mathrm{Cs}$ & Total Alpha, Total Beta \\
\hline 296-P-28 & ${ }^{137} \mathrm{Cs}$ & Total Alpha, Total Beta \\
\hline $296-C-5$ & ${ }^{89190} \mathrm{Sr},{ }^{211} \mathrm{Am}$ & Total Alpha, Total Beta \\
\hline 296-P-16 & ${ }^{137} \mathrm{Cs},{ }^{239240} \mathrm{Pu}$ & Total Alpha, Total Beta \\
\hline 296-P-23 & ${ }^{137} \mathrm{Cs}$ & Total Alpha, Total Beta \\
\hline $296-S-15$ & ${ }^{89190} \mathrm{Sr},{ }^{137} \mathrm{Cs},{ }^{211} \mathrm{Am}$ & Total Alpha, Total Beta \\
\hline 296-S-22 & ${ }^{89190} \mathrm{ST},{ }^{90} \mathrm{Y},{ }^{137} \mathrm{Cs},{ }^{239 / 240} \mathrm{Pu}$ & Total Alpha, Total Beta \\
\hline $296-T-18$ & ${ }^{8998} \mathrm{Sr},{ }^{137} \mathrm{Cs}$ & Total Alpha, Total Beta \\
\hline
\end{tabular}

Subpart H Section 61.93(b)(4)(ii) To determine whether a release point is subject to the emission measurement requirements of paragraph (b) of this section, it is necessary to evaluate the potential for radionuclide emissions for that release point. In evaluating the potentinl of a release point to discharge radionuclides into the air for the purposes of this section, the estimated radionuclide release rates shall be based on the discharge of the effluent streams that would result if all pollution control equipment did not exist, but the facility operations were otherwise nonnal.

Documentation: WHC-SD-WM-EMP-031 
Comparison: The potential off-site doses (ie assuming emission controls did not exist) for the designated stacks are listed below:

\begin{tabular}{|c|c|}
\hline STACK \# & $\begin{array}{c}\text { POTENTIAL OFFSITE DOSE } \\
\text { (mrem/year) }\end{array}$ \\
\hline $296-\mathrm{A}-17$ & 226.0 \\
\hline $296-\mathrm{P}-26$ & 226.0 \\
\hline $296-\mathrm{A}-25$ & 0.11 \\
\hline $296-\mathrm{A}-27$ & 148.0 \\
\hline $296-\mathrm{A}-29$ & 846.0 \\
\hline $296-\mathrm{B}-28$ & 0.16 \\
\hline $296-\mathrm{C}-5$ & 19.0 \\
\hline $296-\mathrm{P}-16$ & 1.68 \\
\hline $296-\mathrm{P}-23$ & 10.5 \\
\hline $296-\mathrm{P}-28$ & 10.5 \\
\hline $296-\mathrm{S}-15$ & 270.0 \\
\hline $296-\mathrm{S}-22$ & 0.34 \\
\hline $296-\mathrm{T}-18$ & 0.18 \\
\hline
\end{tabular}

Subpart H Section 61.93 (b) (S) Envimnmental measurements of redionuclide air concentrations at critical receptor locations may be used as an alternative to air dispersion calculations in demonatrating compliance with the atandand if the owner or opentor meets the following criteria:

Comparison: Not applicable to the discussion within this point-by-point. 


\section{DISTRIBUTION}

Number of Copies

ONSITE

19
Westinghouse Hanford Company

D. D. Bachand

R. L. Brown

G. M. Crummel

W. E. Davis

L. P. Diediker

R. V. Filkowski

L. A. Garner

C. J. Geier

R. D. Gustavson

J. R. Kriskovich

P. J. Martell

S. R. Pierce

B. D. Williamson

Document Processing and Distribtuion (2)

Central Files

Information Release Administration (3)
R1-51

R3-12

R1-51

H6-20

T1-30

S2-45

R1-51

R2-36

R1-51

S2-24

T1-30

R2-70

B3-15

L8-15

L8-04

R1-08 
This page intentionally left blank. 

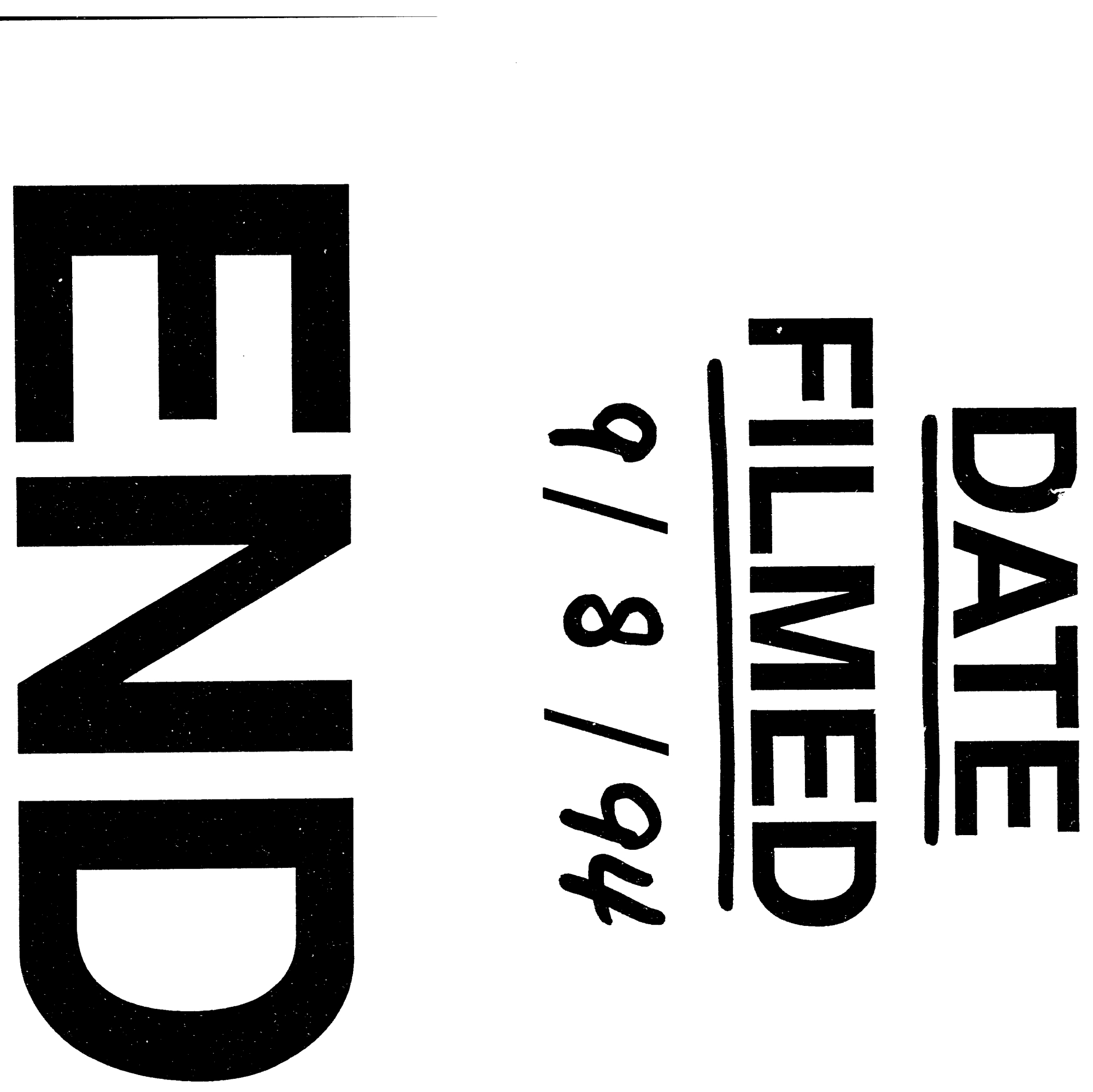


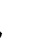

